UNIVERSIDADE DE SÃO PAULO

FACULDADE DE FILOSOFIA, LETRAS E CIÊNCIAS HUMANAS DEPARTAMENTO DE GEOGRAFIA

PROGRAMA DE PÓS-GRADUAÇÃO EM GEOGRAFIA HUMANA

IZAN REIS DE ARAUJO

A Projeção Geopolítica do Brasil na América Latina e os Desafios da Integração Sul-americana

Versão corrigida

São Paulo

2018 
IZAN REIS DE ARAUJO

\title{
A Projeção Geopolítica do Brasil na América Latina e os Desafios da Integração Sul-americana
}

\author{
Versão corrigida
}

Dissertação apresentada ao Programa de Pós-Graduação em Geografia Humana do Departamento de Geografia da Faculdade de Filosofia, Letras e Ciências Humanas da Universidade de São Paulo, para obtenção do título de Mestre em Geografia Humana.

Área de concentração: Geografia Humana

De acordo,

\section{Prof. Dr. André Roberto Martin (Orientador)}

São Paulo

2018 
Autorizo a reprodução e divulgação total ou parcial deste trabalho, por qualquer meio convencional ou eletrônico, para fins de estudo e pesquisa, desde que citada a fonte.

Catalogação na Publicação

Serviço de Biblioteca e Documentação

Faculdade de Filosofia, Letras e Ciências Humanas da Universidade de São Paulo

A658p

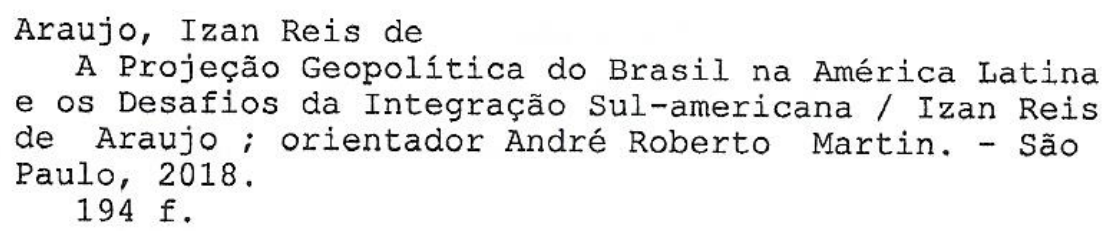

1. Teorias Geopolíticas. 2. Política Externa. 3. América Latina. 4. América do Sul. I. Martin, André Roberto, orient. II. Título. 
FOLHA DE APROVAÇÃO

Izan Reis de Araujo

A Projeção Geopolítica do Brasil na América Latina e os

Desafios da Integração Sul-americana

Dissertação apresentada ao Programa de Pós-Graduação em Geografia Humana do Departamento de Geografia da Faculdade de Filosofia, Letras e Ciências Humanas da Universidade de São Paulo, para obtenção do título de Mestre em Geografia Humana.

Aprovado em:

Banca Examinadora

Prof. Dr. André Roberto Martin - Orientador

Julgamento:

Prof. Dr.

Julgamento:

Prof. Dr.

Julgamento:

Prof. Dr.

Julgamento:
Instituição: USP/ Geografia

Assinatura:

Instituição:

Assinatura:

Instituição:

Assinatura:

Instituição:

Assinatura: 
In memoriam

À minha avó,

Maria dos Reis Filha.

Cujo exemplo de dedicação e sacrifício em prol da educação de seus filhos constituiu um grande legado e estímulo na minha vida.

Dedico também este trabalho a todos os brasileiros que acreditam nesse país e que anseiam por uma América Latina unida, desenvolvida e soberana. 


\section{AGRADECIMENTOS}

Ao Pai Celestial por ter me dado saúde e força para superar as dificuldades.

Ao meu orientador Prof. Dr. André Roberto Martin, confesso que quando entrei na Pós-graduação pensei que ele fosse me ensinar apenas Geopolítica, mas, hoje, vejo que sua influência foi muito além, tornando-se um grande amigo, conselheiro, exemplo de ser humano e de dedicação acadêmica.

Aos Professores Doutores Vitor Start Gabriel de Pieri e Eli Alves Penha, da Universidade do Estado do Rio de Janeiro, pela grande contribuição que deram ao meu aprimoramento intelectual quando participaram da minha banca de qualificação.

À minha família, em especial aos meus pais, Ivo Freitas de Araujo, in memorian, e Maria Raimunda da Conceição Reis de Araujo, pelo imprescindível apoio manifestado na forma de incentivo e carinho.

À minha esposa, Priscila Calixto Braz de Araujo, pelo apoio e amor dedicados ao longo dessa jornada acadêmica.

À minha querida filha, Emily Braz de Araujo, por ser a fonte de motivação permanente na minha vida.

Ao Professor Walter Oliveira, que sempre acreditou no potencial dos seus alunos, pela sua disposição em ensinar-me as primeiras lições que me preparam para a vida acadêmica e por sua amizade verdadeira.

À Secretaria do Programa de Pós-Graduação em Geografia Humana, nas pessoas de Rosângela e Maria Aparecida, pela paciência, atenção e prontidão com que sempre me atenderam.

Ao geógrafo Tito Lívio Barcellos Pereira que atendeu o meu pedido e realizou com exatidão a confecção dos mapas deste trabalho.

À Rosana Portela, que realizou a revisão do trabalho e tradução do texto apresentado no Abstract.

Aos amigos da Universidade de São Paulo, Carlos Henrique, Fábio Brito e Mônica Iha, com os quais pude dividir as minhas ideias e esperanças. 
"Sem a Geografia a gente não consegue ler o mundo, e sem ler o mundo a gente não consegue compreendê-lo".

André Roberto Martin 


\section{RESUMO}

O objetivo deste trabalho foi analisar a projeção geopolítica do Brasil na América Latina, destacando o "espaço" e "posição" do país no quadro geoestratégico mundial e sua relação com a integração regional sul-americana. O tema é importante porque embora existam trabalhos sobre a política externa brasileira em escala regional, o debate teórico sobre a relação entre os conceitos de "América do Sul" e "América Latina" ainda são raros. A hipótese que procuramos sustentar é a de que o recorte espacial sulamericano adotado pelo Itamaraty é decorrente do projeto brasileiro de ser uma potência regional com vistas a obter um maior protagonismo nos processos decisórios internacionais. Contudo, somente a América Latina, do ponto de vista geopolítico, conta com excedentes de recursos suficientes para gerar poder em escala mundial. Na história recente do Brasil, a América do Sul passou a ser entendida como um espaço mais operacional, do ponto de vista político-diplomático para levar adiante o projeto de liderança regional. Origina-se na ALCSA, lançado pelo presidente Itamar Franco em 1993, logo após a entrada do México no NAFTA e essa diretriz foi mantida ao longo das próximas décadas como uma das linhas de continuidade da política externa brasileira, especialmente no governo Lula, que a materializou com a criação da UNASUL em 2008. A metodologia utilizada foi uma pesquisa qualitativa com base em fontes primárias apoiadas em documentos do Itamaraty e na literatura bibliográfica das obras basilares de Friedrich Ratzel, Halford J. Mackinder, Mario Travassos e André Martin. Ao final o trabalho contribuiu para a compreensão de que a América Latina é um espaço vital para a projeção mundial do Brasil, sobretudo no contexto do "meridionalismo" que advoga um sexto player global em torno de um bloco no Hemisfério Sul. Como sugestão de continuidade de pesquisa entendemos que será relevante analisar quais ações da chancelaria brasileira influenciam na formação e no desenvolvimento de um "bloco meridional" com objetivo de buscar um maior protagonismo internacional do Brasil. As aporias da política externa brasileira sobretudo nos últimos anos estariam, portanto, relacionadas a esta imprecisão geopolítica.

Palavras-chave: Teorias Geopolíticas. Política Externa. América Latina. América do Sul. 


\begin{abstract}
The aim of this work is to analyse Brazilian's geopolitical presence in Latin America, highlighting "space" and "position" of the country in the global geostrategic board and its relationship with South American regional inclusion. The theme is relevant given that, although works on Brazilian foreign policy on a regional scale exist, the theoretical debate regarding the relationship between the concepts of "South America" and "Latin America" are still rare. The sought hypothesis is that the South American spatial clipping adopted by Itamaraty is a result of the Brazilian project of becoming a regional power seeking a larger protagonism in international decisive processes. Nevertheless, only Latin America, from the geopolitical perspective, counts on enough resource surpluses to generate global scale power. In Brazilian's recent history, South America has begun to be understood as a more operational space, from the political-diplomatic point of view, in order to proceed with the regional leadership project. It was originated in ALCSA, introduced by former president Itamar Franco, in 1993, following Mexico's insertion in NAFTA and this guideline was kept throughout the following decades as one of the continuity lines of Brazilian's foreign policy, especially during Lula's presidency, which has materialized it with UNASUL's creation, in 2008. The used methodology was a qualitative research based on primary sources backed by Itamaraty's documents and bibliographical literature of fundamental works from Friedrich Ratzel, Halford J. Mackinter, Mario Travassos and André Martin. Finally, the work has contributed to the comprehension that Latin America is a vital space for global projection in Brazil, especially in the "meridionalism" context, which advocates a sixth global player around a Southern Hemisphere block. As a suggestion of continuity of research, we understand that it will be relevant to analyse which actions from Brazilian's chancellery have an influence over the formation and development of a "southern block" aiming to seek a larger international protagonism in Brazil. The difficulty of the Brazilian external policy, especially in the last years, would be, therefore, related to this geopolitical imprecision.
\end{abstract}

Keywords: Geopolitical Theories. External Policies. Latin America. South America. 
LISTA DE SIGLAS

AFRICOM

ALADI

ALALC

ALBA

ALCA

ALCSA

AMAN

BID

BRICS

CAN

CASA

CDS

CEE

CELAC

CENTCOM

CEPAL

CIA

CIJ

COSIPLAN

CPI

CPLP

DNER

ESUDE
Comando da África dos Estados Unidos

Associação Latino-Americana de Integração

Associação Latino-Americana de Livre Comércio

Aliança Bolivariana das Américas

Área de Livre Comércio das Américas

Área de Livre Comércio Sul-Americana

Academia Militar das Agulhas Negras

Banco Interamericano de Desenvolvimento

Brasil, Rússia, Índia, China e África do Sul

Comunidade Andina

Comunidade Sul-Americana de Nações

Conselho de Defesa Sul-Americano

Comunidade Econômica Europeia

Comunidade de Estados Latino Americanos e Caribenhos

Comando Central dos Estados Unidos

Comissão Econômica para a América Latina e o Caribe

Agência Central de Inteligência

Corte Internacional de Justiça

Conselho Sul-Americano de Infraestrutura e Planejamento

Comissão Parlamentar de Inquérito

Comunidade dos Países de Língua Portuguesa

Departamento Nacional de Estradas de Roldagem

Escola Sul-Americana de Defesa 
EUCOM Comando Europeu dos Estados Unidos

FBI

Departamento Federal de Investigação

FEB

Força Expedicionária Brasileira

FOCEM

Fundo para a Convergência Estrutural do MERCOSUL

IIRSA

Iniciativa para a Integração da Infraestrutura Regional SulAmericana

$\mathrm{MCM}$

Medidas de Confiança Mútua

MERCOSUL Mercado Comum do Sul

NORTHCOM Comando Norte dos Estados Unidos

NSA

Agência de Segurança Nacional dos Estados Unidos

OEA

Organização dos Estados Americanos

$\mathrm{OMC}$

Organização Mundial do Comércio

ONU

Organização das Nações Unidas

OPA

Operação Pan-Americana

OPEP Organização dos Países Exportadores de Petróleo

OTAN

Organização do Tratado do Atlântico Norte

PACOM

Comando do Pacífico dos Estados Unidos

PARLASUL

Parlamento do Sul

PEAS

Plano Estratégico de Ação Social

PICE

Programa de Integração e Cooperação Econômica

PL

Partido Liberal de Honduras

SGAS

Subsecretaria-Geral da América do Sul

SOUTHCOM

Comando Sul dos Estados Unidos

TIAR

Tratado Interamericano de Assistência Recíproca

TNP

Tratado de Não Proliferação Nuclear 
TPP

UNASUL
Parceria Transpacífico

União de Nações Sul-Americanas 


\section{LISTA DE GRÁFICOS}

Gráfico 1: Total de conflitos armados por região (2006-2015).

Gráfico 2: Participação da OPEP nas reservas mundiais de petróleo bruto (2016). 91

Gráfico 3: Os dez maiores gastos militares do mundo em 2016 (em bilhões US\$). 


\section{LISTA DE FIGURAS}

Figura 1: O quadro denominado Progresso Americano de John Gast (1872).... 67

Figura 2: Theodore Roosevelt e sua política do Big Stick no Caribe (1904)..... 73 


\section{LISTA DE MAPAS}

Mapa 1: Núcleo Geohistórico do Meridionalismo.

Mapa 2: Geopolítica de Tordesilhas segundo Therezinha de Castro.

Mapa 3: Tratados que delimitaram as fronteiras do Brasil (1494-1801). 26

Mapa 4: Dois antagonismos geográficos na América do Sul. 33

Mapa 5: Centralidade do sistema ferroviário argentino. 35

Mapa 6: Potencialidade amazônica no Altiplano boliviano. 37

Mapa 7: O heartland sul-americano e seus corredores de exportação... 39

Mapa 8: A cordilheira dos Andes e as regiões Pasos e Nudos 40

Mapa 9: Regionalização do Brasil segundo Mario Travassos. 41

Mapa 10: Projeção de Mercator. 50

Mapa 11: Projeção de Mackinder. 51

Mapa 12: O “Cordão Sanitário” mackinderiano (1919). 54

Mapa 13: Europa após a Primeira Guerra Mundial (1921). 55

Mapa 14: Plano Geral de Viação Nacional (1934). 57

Mapa 15: O território da Nova França (Luisiana) no início do século XIX.

Mapa 16: Expansão territorial dos Estados Unidos (1776-1898) 69

Mapa 17: O Projeto Monopolar dos Estados Unidos 85

Mapa 18: Primeiras iniciativas de integração regional da América Latina 105

Mapa 19: Regionalização geoeconômica e geopolítica da América Latina

Mapa 20: Documentos de Políticas de Defesa na América Latina.

Mapa 21: As Pan-regiões de Haushofer (1937). 129

Mapa 22: O Meridionalismo e a Teoria do Sexto Poder de André Martin. 136 


\section{SUMÁRIO}

APRESENTAÇÃO ........................................................................................... XVI

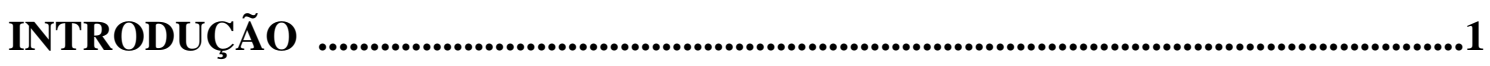

CAPITULO I - O PENSAMENTO GEOPOLÍTICO BRASILEIRO SOBRE A

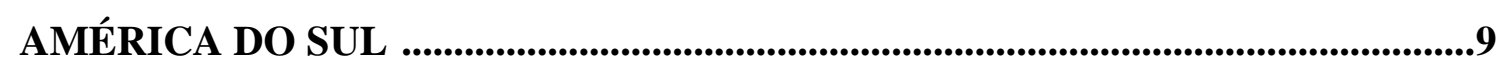

1. Introdução à Geografia Política e Geopolítica ..........................................................

1.1 A origem e os precursores da geopolítica brasileira ..............................16

1.1.1 Teoria geopolítica pré-esguiana: Mário Travassos .....................31

1.1.2 Influência de Mackinder ........................................................48

1.2 Vargas e a articulação do espaço brasileiro na perspectiva travassiana .. 56

\section{CAPÍTULO II - AMÉRICA LATINA: FORÇAS CENTRÍPETAS E FORÇAS}

CENTRÍFUGAS ........................................................................................................60

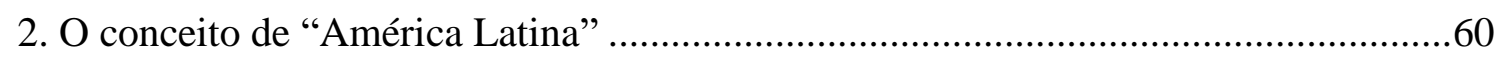

2.1 O Discurso do Pan-americanismo.............................................................65

2.1.1 Destino Manifesto e Monroísmo na política externa dos EUA ..66

2.1.2 Bolívar e a sua geoestratégia contra-hegemônica .......................74

2.2 Arquitetura contemporânea de segurança regional .................................79

2.3 Instituições de Segurança ..................................................................92

\section{CAPÍTULO III - O PAPEL DO ESTADO BRASILEIRO NA AMÉRICA}

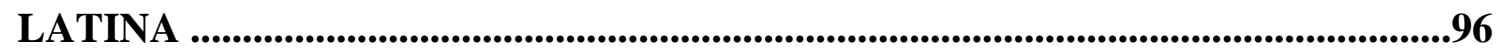

3. Operação Pan-Americana e a inserção do Brasil na América Latina ........................ 96

3.1 A Integração regional na agenda do Itamaraty ....................................100

3.1.1 América do Sul e a UNASUL ...............................................106

3.1.2 América Latina e seu coeficiente de poder ..............................113

3.2 A crise brasileira e seu desdobramento geopolítico na América Latina.. 122

3.3 Meridionalismo: um paradigma para a política externa brasileira? ........132

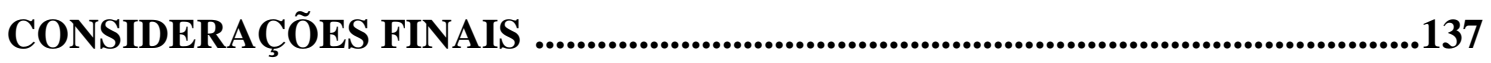

REFERÊNCIAS [...............................................................................................141

ANEXOS 


\section{APRESENTAÇÃO}

Quando eu lecionava Geografia no ensino fundamental e médio tive a oportunidade de abordar vários temas, mas o que me chamou atenção foi a questão da regionalização do espaço mundial, porque embora uma parte significativa dos alunos se interessasse pela aula, para minha surpresa, quando comecei a passar atividades em grupo, como seminários, por exemplo, a turma tinha uma preferência em escolher as regiões situadas no Hemisfério Norte como Europa e América do Norte. Poucos eram aqueles que buscavam pesquisar sobre a América Latina e os demais países do Hemisfério Sul. Assim, comecei a pensar no motivo dessa preferência, uma vez que eles eram todos latino-americanos. Como abordar a América Latina num quadro desfavorável como aquele vivenciado em sala de aula? De que maneira poderia despertar a curiosidade deles pela região? De que modo poderia explicar aos alunos a importância da região, sobretudo no contexto atual, em que o Brasil buscou até pouco tempo um protagonismo internacional através das relações Sul-Sul?

As conclusões preliminares a que estava chegando durante as aulas indicavamme claramente que, em primeiro lugar, essa falta de interesse dos alunos em pesquisar sobre a América Latina e os demais países do Hemisfério Sul está ligada, de certo modo, à longa exploração colonial a qual a região foi submetida e que, a rigor, ainda não nos libertamos inteiramente. Para André Martin, "temos grande dificuldade em nos afirmar perante o mundo em função justamente do nosso próprio complexo de inferioridade". Consequentemente, há "uma rejeição de tudo o que é próprio e característico, como se ser brasileiro correspondesse a algum defeito ou desvio de caráter congênito"1.

Em segundo lugar, as grandes potências mundiais não detêm apenas um poderio militar colossal, mas também possuem aquilo que Joseph Nye denominou de soft power. Para Nye, embora o hard power ainda seja um instrumento de poder predominante nas relações internacionais, a cultura pode possibilitar novas formas de poder $^{2}$. Ele identifica importantes fontes de soft power nas empresas transnacionais e na cultura popular americana, sintetizadas no slogan American way of life, tudo isso é

\footnotetext{
${ }^{1}$ MARTIN, André Roberto. Fronteiras e nações. São Paulo: Contexto, 1992, p. 9.

${ }^{2}$ NOUR, Soraya. À paz perpétua de Kant: filosofia do direito internacional e das relações internacionais. São Paulo: Martins Fontes. 2004, p. 125.
} 
incorporado em produtos e comunicações, que dispõem de um grande apelo, levando milhares de pessoas, especialmente os jovens, a se identificarem com os valores liberais tais como: individualidade, competitividade e modernidade, em detrimento da coletividade, solidariedade e de sua cultura local com seus antigos valores, crenças e tradições arraigadas. Não é por acaso que Celso Amorim dizia que "questões de política externa são muito importantes à sociedade", porque "refletem na percepção das pessoas, no modo como elas se veem no mundo" "3. Por isso mesmo, é que neste trabalho buscouse pesquisar sobre a América Latina para demonstrar justamente a sua importância singular, sobretudo para nós brasileiros.

${ }^{3} \mathrm{O}$ Brasil não pode se ausentar das questões mundiais, alerta Celso Amorim. Instituto Lula. 4 jul. 2016. Disponível em: <http://www.institutolula.org/o-brasil-nao-pode-se-ausentar-das-questoes-mundiaisalerta-celso-amorim>. Acesso em: 5 jul. 2016. 


\section{INTRODUÇÃO}

O objetivo deste trabalho é analisar a projeção geopolítica do Brasil na América Latina, destacando o "espaço" e a "posição" do país no quadro geoestratégico mundial e sua relação com a integração regional sul-americana. Para isso, destacaremos duas escalas de análise importantes para a chancelaria brasileira: a América do Sul e a América Latina. Abordaremos essas regiões conceitualmente, sobretudo destacaremos que em cada recorte espacial há campos de forças centrípetas e centrífugas que se opõem geopoliticamente.

O tema se justifica porque na maioria dos trabalhos sobre a diplomacia brasileira em escala regional é abordado apenas o recorte espacial sul-americano. Este trabalho, porém, faz um debate teórico sobre a relação entre os conceitos de "América do Sul" e "América Latina". Com essa abordagem, buscamos resgatar a importância da geopolítica como um instrumento teórico-metodológico relevante para a formulação da política externa do país.

Desse modo, nos lançamos, em 2014, em direção a uma pesquisa visando utilizar como referencial teórico-metodológico as três categorias de Ratzel: espaço, posição e Estado. Há pouco mais de um século, Friedrich Ratzel (1844-1904) publicou a obra Politische Geographie, em 1897, na qual estabeleceu os fundamentos da "nova ciência”. Dentre as suas principais contribuições, a teoria de que cada Estado tem sua vida política condicionada por dois fatores geográficos "espaço" e "posição" chamaramme atenção. As considerações ratzelianas influenciaram-me desde as minhas primeiras aulas de Geografia Política. Primeiro, porque sua abordagem permite uma análise mais concreta e objetiva da política externa dos Estados pelo fato de ele geografizá-la, distinguindo-o dos cientistas políticos cujas análises teóricas estão cada vez mais no plano da metafísica, exigindo um alto grau de abstração.

Segundo, porque justamente passado mais de um século de sua morte, é possível afirmar que suas teorias e conceitos continuam vivos e apresentam relevantes contribuições teóricas para a análise das relações internacionais contemporâneas. Portanto, reivindicar a atualidade do geógrafo alemão e prussiano não é mera figura retórica, mas sim demonstrar que seu argumento pode ser comprovado ao analisarmos o cenário geopolítico mundial contemporâneo, cuja tendência é uma ordem mundial "tripolar", entre os Estados Unidos, a China e a Rússia. Não por acaso esses três 
Estados possuem um grande "espaço" e uma "posição" geográfica relevante no quadro geoestratégico mundial. Diante disso, tudo leva a crer que os postulados ratzelianos continuam atuais quando cotejados na realidade em pleno século XXI.

Por isso mesmo, buscamos enquadrar as suas ideias no objeto de estudo do presente trabalho, destacando seus fundamentos teóricos e metodológicos. Ademais, como bacharel em Relações Internacionais, percebo que, nesse campo de estudo, a geopolítica é pouco difundida, por essa razão me especializei em Geografia Humana porque sei da importância de geografizar a política para melhor compreendermos o mundo. Além disso, nas Relações Internacionais há o predomínio de outro viés de interpretação do sistema internacional, pautado mais no idealismo, que vê no respeito ao Direito Internacional, nas convenções internacionais e nas instituições intergovernamentais um meio de se buscar a paz pelo comércio. Conforme afirmava o filósofo francês Montesquieu no seu livro Do Espírito das Leis, publicado em 1748, em que ele diz que "o efeito natural do comércio é o de levar à paz"4, uma vez que o comércio gera uma relação recíproca de dependência e interesses comuns entre as nações.

Diferentemente desse paradigma liberal dominante no campo das Relações Internacionais, a geopolítica utiliza como instrumento de análise o paradigma realista, tendo em vista a disputa pelo poder mundial. Assim sendo, faremos aqui um breve debate introdutório em torno destas duas correntes teóricas clássicas: o liberalismo e o realismo, dado que ambas explicam de formas distintas o mesmo sistema internacional.

O liberalismo é a primeira abordagem teórica das Relações Internacionais. Seus principais pensadores clássicos são Immanuel Kant, com a sua obra mais conhecida, $A$ Paz perpétua, publicada em 1795, Jean-Jacques Rousseau, no seu livro O Contrato Social, editado em 1762, e o jurista Hugo Grotius, que escreveu De Mare Liberum, em 1609, e Direito de Guerra e Paz, publicado em 1625. Esse paradigma ganha força no pós-Primeira Guerra Mundial quando o presidente dos Estados Unidos Woodrow Wilson apresentou os 14 pontos e propôs a criação da Liga das Nações, em 1919, com vistas a evitar outra guerra.

Em função de os acadêmicos ligados a essa corrente fazerem uma leitura mais otimista e menos maliciosa do sistema internacional, o liberalismo foi rotulado pelos seus críticos de "idealistas" porque pensavam na política internacional em termos do

\footnotetext{
${ }^{4}$ MONTESQUIEU. Charles de. Do Espírito das Leis. São Paulo: Editora Martin Claret, 2005, p. 334.
} 
deve ser, em vez de estudar como realmente é, ou seja, como funciona de fato a correlação de forças entre os Estados nas relações internacionais.

Com a Segunda Guerra Mundial, o mundo passou por grandes mudanças, e estas ensejaram a busca de novos caminhos, de novas linguagens, de novas propostas, enfim, de uma maior possibilidade de reflexão e criação frente ao mundo que se descortinava, pois ficou demonstrado empiricamente que o idealismo wilsoniano não foi capaz de evitar a guerra.

Em oposição ao idealismo wilsoniano, surge a Escola Realista de Relações Internacionais. A crise do idealismo foi benéfica, pois introduziu um novo pensamento crítico, isto é, o realismo passou a ser visto como uma possibilidade naquele momento, sobretudo para analisar o sistema internacional, em particular a questão da guerra. Assim como o liberalismo, o realismo também foi inspirado em pensadores clássicos, seus expoentes são Thomas Hobbes, na sua obra Leviatã, publicada em 1651, Tucídides, em A Guerra do Peloponeso, ocorrida no século V a.C., e Nicolau Maquiavel, com sua obra clássica $O$ Príncipe, de 1532. Os principais conceitos do paradigma realista têm influência desses autores.

Hobbes, por sua parte, deixou como elemento-chave para análise dos realistas, o conceito de "estado de natureza" que é comparado com o estado de anarquia do sistema internacional $^{5}$. Não quer dizer que seja um sistema internacional desorganizado, mas é entendido como um sistema descentralizado. Sendo assim, não há um "Leviatã" no plano internacional, ou seja, não existe uma autoridade central e soberana em escala mundial, que possua aquilo que Max Weber chamou em Ciência e Política Duas Vocações de "monopólio legítimo da força" a segurança e a sobrevivência de todos os demais Estados do sistema internacional, surge uma desconfiança permanente entre os países, resultando em conflitos.

Diferentemente dos realistas, para os liberais, a única maneira de se evitar uma guerra no sistema internacional anárquico é por intermédio de um contrato social feito em escala mundial numa perspectiva rousseaniana. Assim, surge entre os idealistas o respeito ao Direito Internacional com suas normas, tratados, convenções e instituições intergovernamentais. Já para os realistas, como o sistema internacional é anárquico, logo constitui uma ameaça à sobrevivência dos Estados, por isso mesmo, eles definem

\footnotetext{
${ }^{5}$ NOGUEIRA, João pontes; MESSSARI, Nizar. Teoria das relações internacionais: correntes e debates. Rio de Janeiro: Elsevier, 2005, p. 22.

${ }^{6}$ WEBER, Marx. Ciência e Política: duas vocações. São Paulo: Editora Martin Claret, 2006, p. 16.
} 
questões de segurança e defesa como prioridade na sua agenda política e como finalidade última da ação do Estado.

De Tucídides, os realistas destacaram o conceito de "balança de poder" que consiste em quando um Estado busca neutralizar a potência hegemônica por meio de alianças com outros Estados menores. Se houver um "equilíbrio de poder" entre os Estados haverá uma tendência natural de manutenção da paz, pois nenhuma potência se sentirá em condições de ameaçar a outra, mas, por outro lado, se houver um "desequilíbrio" nessa balança, logo poderá eclodir um conflito ou mesmo uma guerra como foi a Guerra do Peloponeso entre Atenas e Esparta descrita por Tucídides há cerca de 2.500 anos.

Por fim, Maquiavel ensinou o princípio "razão de Estado" para mostrar que um príncipe sem um Estado perde toda a relevância. Não é por acaso que ele vai costurar alianças com vistas a garantir a existência e a segurança do seu Estado, mesmo que para isso, seja necessário abrir mão de qualquer caráter moral ou ético. Segundo Maquiavel, a moralidade que orienta as ações do indivíduo não se aplica nem deveria orientar as ações do príncipe ${ }^{7}$.

Os grandes teóricos da Escola Realista são Edward Hallet Carr, um diplomata britânico que escreveu o livro Vinte anos de crise, publicado em 1939, poucos meses antes do início da Segunda Guerra Mundial. Outro expoente é Hans Morgenthau, que escreveu, em 1948, A política entre as nações.

Para os realistas, o sistema internacional é constituído por Estados que guerreiam entre si, comparativamente a um jogo de bilhar, que tem sobre a mesa apenas bolas que se chocam. Já na visão liberal, embora os Estados sejam os principais atores nas relações internacionais, eles não são as únicas peças no tabuleiro. Para essa corrente teórica, o sistema internacional é comparado a um tabuleiro de xadrez composto por várias peças diferentes, cada qual com suas funções e valores distintos, isto é, Estados nacionais, organizações intergovernamentais, empresas transnacionais, ONGs etc.

Outros paradigmas surgiram nas décadas seguintes, em função das mudanças que o mundo passava - surgimento de novos Estados após as descolonizações na África e Ásia, na década de 1950 e 1960, a emergência de atores não estatais nas relações internacionais e o fim da Guerra Fria, em 1991 - como o neoliberalismo, o

\footnotetext{
${ }^{7}$ NOGUEIRA, João pontes; MESSSARI, Nizar. Op. cit., 2005, p. 22.
} 
neorrealismo, a teoria marxista da dependência, o construtivismo, o realismo periférico, dentre outros.

Portanto, podemos observar que os desdobramentos das teorias das Relações Internacionais são muitos e cada internacionalista adotará a postura que lhe for mais conveniente.

Isto posto, o problema central da pesquisa consiste em desvelar qual deve ser o espaço privilegiado de atuação da política externa brasileira que melhor corresponda com as potencialidades geopolíticas do país: América do Sul ou América Latina? Neste estudo, o governo brasileiro e o Itamaraty serão objetos de análise, no período de 1993 até a atualidade. $\mathrm{O}$ tema de pesquisa é desafiador porque sai um pouco dos cânones dos estudos aos quais estamos acostumados a ler sobre a América do Sul. Neste trabalho, buscamos ampliar nossa escala de análise para a América Latina. É uma ousadia porquê do ponto de vista da diplomacia brasileira essa escala é um pouco comparada com o "lado obscuro da lua". Até mesmo os Estados Unidos que têm uma projeção geopolítica em escala global, o "lado obscuro da lua", para Washington, até os anos 90, era a Ásia Central que estava oculta pela URSS.

No caso brasileiro, o "lado obscuro da lua" é a América Central, o Caribe, além da borda caribenha da América do Sul que está oculta pela presença econômica-militar ${ }^{8}$ dos Estados Unidos. Segundo Nicholas J. Spykman (1893-1943), toda essa região é denominada de "mediterrâneo americano". Para ele, não é apenas uma zona de influência, mas sim uma área de presença imediata do seu poderio aeronaval em que a sua supremacia não pode ser questionada. Ou seja, trata-se de um mare clausum $^{9}$.

Para o geógrafo americano, a abertura dos canais do Panamá e de Suez dividiu as massas terrestres do globo em cinco grandes ilhas continentais. Dessas cinco ilhas, duas situam-se no Hemisfério Ocidental - América do Norte e América do Sul - e as outras três localizam-se no Hemisfério Oriental - Eurásia, África e Austrália ${ }^{10}$. Em seguida, ele vai aplicar a sua teoria do poder anfíbio na América Latina, dizendo que

\footnotetext{
${ }^{8}$ A presença imediata dos Estados Unidos no "mediterrâneo americano" ocorre pelos acordos de livre comércio na região através do NAFTA que também inspirou na criação do CAFTA na América Central e na República Dominicana. Já do ponto de vista estratégico pelas bases militares na região, a Quarta Esquadra e o Comando Sul, inclusive ações de desestabilização de governos nacionais como faz abertamente com os países que tem borda caribenha como a Venezuela e a presença militar ostensiva nas bases militares na Colômbia.

${ }^{9}$ SPYKMAN, Nicholas John. America's strategy in world politics: The United States and the balance of power. New York: Harcourt, Brace, and Company, 1942, p. 60.

${ }^{10}$ MELLO, Leonel Itaussu Almeida. Quem tem medo da geopolítica? 2. Ed. São Paulo: Hucitec Instituto Leonel Itaussu, 2015, p. 96.
} 
qualquer ameaça à hegemonia dos Estados Unidos na região deverá vir da América do Sul, em particular da Argentina, do Brasil e do Chile, a "região do ABC". Nas palavras do próprio Spykman:

Os países situados fora da nossa zona de presença imediata, os grandes Estados da América do Sul podem tentar contrabalançar o nosso poder por meio de uma ação comum ou mesmo do uso de influências de fora do Hemisfério ${ }^{11}$. Nesse caso, conclui que "se isso ocorrer, a nossa hegemonia só poderá ser afirmada ao custo da guerra" ${ }^{2}$.

A teoria do Rimland de Spykman é importante para pensar na América do Sul como sendo uma "ilha continente" e na geoestratégia do cerco norte-americano no subcontinente para impedir justamente que as potências terrestres, isto é, a Argentina, o Brasil e o Chile, se transformem em potências anfíbias e juntas ameacem a hegemonia do sea power anglo-saxão na América Central e no Caribe. A reativação da Quarta Esquadra demonstra empiricamente que o pensamento geopolítico de Spykman permanece atual em pleno século XXI.

De certo modo, isso explica um pouco o motivo pelo qual a América Latina não tem sido uma escala estudada, pois há uma dificuldade em abordar a região do ponto de vista da geografia política e da geopolítica. O que se pode perceber é que embora haja uma identidade latino-americana, culturalmente falando, não há objetivamente uma geopolítica latino-americana no sentido de uma de estratégia, por outro lado, na América do Sul há uma geopolítica, mas não há uma identidade. Esse é o desafio que reconhecemos na presente pesquisa. Por isso mesmo, buscamos neste trabalho articular três teorias geopolíticas - travassianismo, meridionalismo e o poder perceptível - para pensar num constructo de integração da América Latina, tendo o Brasil como o seu legítimo representante num bloco meridionalista para justamente romper o cerco sulamericano e transpor a barreira da presença americana na América Central e no Caribe.

O travassianismo é importante porque ajuda a pensar o Estado brasileiro como sendo a potência terrestre da "ilha continente" sul-americana, o meridionalismo dar continuidade ao pensamento geopolítico brasileiro, colocando o nosso país no rol das grandes potências anfíbias mundiais e, finalmente, a teoria do poder perceptível confere

\footnotetext{
${ }^{11}$ SPYKMAN, Nicholas John. Op. cit., 1942, p. 64.

12 Ibidem, p. 62.
} 
à América Latina um protagonismo internacional, sobretudo num mundo em que se valorizam tanto os dados estatísticos para a formação de blocos econômicos.

Para respondermos o problema da pesquisa, a hipótese que procuramos sustentar é a de que embora o recorte espacial sul-americano, adotado pelo Itamaraty, seja decorrente do projeto brasileiro de ser uma potência regional com vistas a obter um maior protagonismo nos processos decisórios internacionais, somente a América Latina, do ponto de vista geopolítico, conta com excedentes de recursos suficientes para gerar poder em escala mundial. Para comprovar esse argumento, estruturamos o trabalho em três capítulos.

No primeiro capítulo, utilizaremos o conceito de "espaço" (raum) de Ratzel para mostrar que a América do Sul é o espaço geográfico do Brasil. Iniciaremos este tópico com uma breve discussão teórica sobre Geografia Política e Geopolítica. Em seguida, serão apresentadas a origem e os precursores da Geopolítica no país. Abordaremos, ainda, a Escola Geopolítica Brasileira na perspectiva pré-esguiana, destacando, particularmente, a obra de Mario Travassos Projeção Continental do Brasil. Por fim, analisaremos de que maneira o modelo travassiano se articulou com as políticas territoriais do país, em especial no governo Vargas.

No segundo capítulo, abordaremos a América Latina com um enfoque multidisciplinar, problematizando a versão geopolítica e literária sobre a origem do termo. Em seguida, será apresentado, de um lado, o discurso do Pan-americanismo originário no monroísmo e, de outro lado, o hispano-americanismo na perspectiva do bolivarianismo e seus desdobramentos na arquitetura contemporânea de segurança regional. Por fim, destaca-se a nova reconfiguração geopolítica latino-americana no contexto das instituições de segurança regionais contemporâneas como a UNASUL e a CELAC.

No terceiro capítulo, finalmente, abordaremos a inserção do Estado brasileiro na América Latina, inicialmente com a Operação Pan-Americana e, em seguida, o estudo será direcionado para o processo de integração regional na agenda do Itamaraty, desde 1960 até os nossos dias. Analisaremos a América Latina do ponto de vista do seu coeficiente de poder para demonstrar que a região possui excedentes de recursos suficientes para gerar poder em escala global. Explicaremos a crise política brasileira e seu desdobramento geopolítico na região. Utilizaremos ainda a teoria "meridionalista" brasileira de André Martin, para mostrar que a América Latina é a posição (lage) 
geográfica do Brasil em escala regional e um espaço vital para a projeção mundial do nosso país.

Nas considerações finais, procuraremos retomar sinteticamente o tema da pesquisa e reforçar a tese defendida, colocando em destaque as principais conclusões a que chegamos e que justificam o trabalho e a elaboração desta dissertação.

Apresentaremos, a seguir, a metodologia do projeto com a descrição dos métodos de interpretação, as técnicas de pesquisa, e os instrumentos de coleta de dados utilizados para a obtenção das informações relacionadas aos objetivos do trabalho.

O método de interpretação e análise apoia-se na abordagem marxista do imperialismo aliado com as teorias geopolíticas, pois ambas explicam a desigual distribuição de poder político na superfície da Terra e permitem compreender com mais pormenores a intrincada disputa pelo poder mundial que permeia o campo das relações internacionais contemporâneas. De fato, como bem observou Lenin, a partilha do mundo entre as grandes potências ocorre porque o grau de concentração do capital a que chegaram "os obriga a seguir esse caminho para obterem lucros, e repartem-no 'segundo o capital', 'segundo a força'; qualquer outro processo de partilha é impossível no sistema de produção mercantil e no capitalismo"13.

Tendo definido a técnica de investigação ou pesquisa em dados provenientes de fontes primárias tais como: análise bibliográfica, documental e cartográfica, o estudo compreenderá três instrumentos de coleta de dados: o primeiro será a pesquisa bibliográfica, onde serão analisadas as obras basilares de Friedrich Ratzel, Halford J. Mackinder, Mario Travassos e André Martin. Em seguida, a pesquisa documental caracterizará o segundo instrumento de coleta de dados, pois permitirá levantamentos de dados primários apoiados em documentos originais do Governo brasileiro, publicados pelo Itamaraty, que se encontram no anexo deste trabalho. Por fim, o terceiro instrumento será a análise cartográfica, onde faremos levantamentos de mapas de projeções geopolíticas que permitam compreender a conjuntura política nacional, regional e internacional. O tipo de pesquisa quanto aos objetivos do presente trabalho é definido como pesquisa explicativa. Já no que concerne à natureza dos dados é uma pesquisa qualitativa.

\footnotetext{
${ }^{13}$ LENIN, Vladimir Llitch. Imperialismo, estágio superior do capitalismo. São Paulo: Expressão Popular, 2012, p. 108.
} 


\section{CAPÍTULO I - O PENSAMENTO GEOPOLÍTICO BRASILEIRO SOBRE A AMÉRICA DO SUL}

Geopolítica é a política feita em decorrência das condições geográficas.

Neste primeiro capítulo, utilizaremos o conceito de "espaço" (raum) de Ratzel para mostrar que a América do Sul é o espaço geográfico do Brasil. Iniciaremos este tópico com uma breve discussão teórica sobre Geografia Política e Geopolítica. Em seguida, serão apresentadas a origem e os precursores da Geopolítica no país. Abordaremos, ainda, a Escola Geopolítica Brasileira na perspectiva pré-esguiana, destacando, particularmente, a obra de Mario Travassos Projeção Continental do Brasil. Por fim, analisaremos de que maneira o modelo travassiano se articulou com as políticas territoriais do país, em especial no governo Vargas.

\section{Introdução à Geografia Política e Geopolítica}

A palavra "Geopolítica", às vezes, é mal compreendida porque as pessoas desconhecem a história da construção do conceito. Ela surge no fim do século XIX, quando o geógrafo alemão e prussiano Friedrich Ratzel (1844-1904) publicou a sua obra Politische Geographie (Geografia Política: uma geografia dos Estados, do comércio e da guerra), em 1897, na qual estabelece os fundamentos da "nova ciência" ao sistematizar ideias e elaborar conceitos sobre a Geografia Política dos Estados. Pouco tempo depois, sua obra vai servir de inspiração ao geógrafo sueco Rudolf Kjéllen, que empregou o termo "Geopolítica", pela primeira, vez em 1899, numa Conferência ${ }^{15}$. Mais tarde, Kjéllen reafirma as bases da geopolítica no seu livro $O$ Estado como forma de vida, editado em 1916, na Suécia ${ }^{16}$.

\footnotetext{
${ }^{14}$ BACKHEUSER, Everardo. Geopolítica e Geografia Política. Revista Brasileira de Geografia. Rio de Janeiro: IBGE, n. 1, jan./mar., 1942, p. 22.

${ }^{15}$ MARTIN, André Roberto. Geopolítica e Poder Mundial. In: CASTELAR, Sônia Maria Vanzella; MARTINS, Elvio Rodrigues (Org.). Geografia. São Paulo: Secretaria de Estado da Educação, Universidade de São Paulo, 2004, p. 18.

${ }^{16}$ VESENTINI, José William. Novas geopolíticas. 5. ed. São Paulo: Contexto, 2011, p. 15.
} 
Esse livro tornou-se um divisor de águas, porque justamente, nele, Kjéllen mostra que a geopolítica não é apenas um privilégio das grandes potências mundiais, mas, pelo contrário, o próprio termo surgiu na Suécia, um pequeno país periférico na Europa setentrional. Para ele, a geopolítica nasce na periferia que está inconformada com a hegemonia britânica e busca, portanto, quebrar o seu status quo.

Conforme observa Andrés Rivarola:

\begin{abstract}
Justamente en esta búsqueda de pensamiento propio, independiente de las grandes potencias y sus intereses, se origina el concepto "geopolítica" en el trabajo de Rudolf Kjellén. No es entonces desde la perspectiva de una gran potencia sino de un académico proveniente de una nación y Estado pequeño en la periferia del norte europeo donde surge el concepto ${ }^{17}$.
\end{abstract}

Ao analisar a geohistória da formação dos Estados continentais, Kjéllen utilizou o termo "Estado organicista"18, para compreender a sua expansão territorial, seu processo de nascimento, crescimento e morte. Com base nesse estudo, ele deixou dois postulados importantes: a) Estados virtualmente fortes, com áreas de soberania limitada, são dominados pelo categórico imperativo político de dilatar seus territórios, quer seja pela colonização, pela união com outros Estados ou pela conquista; b) aos Estados pequenos parece estar reservada, no mundo da política internacional, sorte idêntica à dos povos primitivos no mundo da cultura - são repelidos para a periferia, mantidos nas áreas marginais ou zonas fronteiriças, ou desaparecem ${ }^{19}$.

Ainda nessa linha, no final do século XIX, Ratzel identificou três Estados continentais: Estados Unidos, Rússia e China. Segundo ele, em longo prazo, a única opção para os pequenos Estados era agruparem-se ou serem absorvidos. Essa tese se confirmava empiricamente com o expansionismo estado-unidense no Texas e do russo no oeste e no Cáucaso. Não por acaso que Ratzel será um intelectual engajado na unificação alemã.

A Geopolítica surge nesse contexto, muito embora seu significado já tenha sido explorado por vários pensadores e governantes, desde a Antiguidade, ao estruturarem os seus grandes impérios e alertarem para a influência do meio geográfico na organização

17 RIVAROLA, Andrés. Prólogo. In: BARRIOS, Miguel Ángel. Diccionário latinoamericano de seguridad y geopolítica. Buenos Aires: Biblos, 2009, p. 18.

${ }_{18}$ Para Kjéllen, o Estado é um ser vivo, como um ser humano. Daí decorre o conceito de "Estado Organicista", porque justamente, no entendimento dele, o Estado estaria organicamente unido ao solo, isto é, ao território, seguiria crescendo, sempre lutando por mais espaço (MAFRA, Roberto Machado de Oliveira. Geopolítica: introdução ao estudo. São Paulo: Sicureza, 2006, p. 44, 46).

${ }^{19}$ Ibidem, p. 51. 
e mesmo no caráter das $\operatorname{sociedades}^{20}$. Por que a Geopolítica adquiriu esse nome?

Primeiro porque se tratava de uma política global, em escala mundial, tanto é assim que "mundo" em alemão é Welt, ou seja, "Weltpolitik"; na Alemanha queria dizer justamente "política mundial". Consequentemente, a Alemanha tornou-se o epicentro da Geopolítica.

A Alemanha, até então atrasada em termos de industrialização pela Inglaterra e França, chegava ao final do século XIX com uma base industrial poderosa, mas sem possuir colônias. Por isso mesmo, em 1890, o Kaiser Guilherme II abandonou a Realpolitik exonerando Bismarck da chancelaria alemã - ele mantinha o equilíbrio de poder europeu sem pretensões imperialistas ${ }^{21}$-, e passou a utilizar em seu lugar a Weltpolitik como uma bússola para a sua nova política externa com vistas a alcançar "um lugar ao sol" para a Alemanha, colocando o país no rol das grandes potências mundiais.

Não é por acaso que a Alemanha criou um programa de construção naval em 1898, dando início a sua Weltpolitik. Segundo Margaret MacMillan²2 e Elysio de Carvalho $^{23}$, o aparecimento de duas obras são fundamentais para apoiar a política naval do Kaiser Guilherme II. A primeira surge pela primeira vez, em 1890, de autoria do almirante estado-unidense Alfred T. Mahan, A influência do poder marinho sobre a

\footnotetext{
20 "Na Grécia clássica, Aristóteles (384-322 a.C.) assinalou com frequência a dependência da Ciência Política em relação à Geografia. Depois dele, Estrabão (63 a.C. - 21 d.C.), considerado por muitos como o 'pai' da Geografia Humana, escreveria boa parte de sua obra com o intuito de influenciar o processo de tomada de decisões dos governantes de sua polís. Passando pela Idade Média, com Alberto Magno (12061280) e na Era Moderna, Montesquieu (1689-1755), talvez o pensador político mais influente da escola 'iluminista", por fim na idade contemporânea, Napoleão Bonaparte (1769-1821), o Imperador e grande General demonstrou já ser um geopolítico, mesmo antes do surgimento da ciência, ao afirmar que 'a política de um Estado está em sua Geografia'. "Eram eles juntamente com muitos outros pensadores que poderiam ser colocados ao lado dos nomes mencionados os precursores da Geopolítica, só que não atendiam pelo nome de 'geopolíticos', algo que só começou a ocorrer nas primeiras décadas do século $\mathrm{XX}$, quando a disciplina passou a ser ensinada em Universidades. Foram além disso, poucos os países a adotar e desenvolver esse novo ramo da Geografia nos seus primórdios: Suécia, Alemanha, Estados Unidos, Inglaterra e Japão" (MARTIN, André Roberto. Op. cit., 2004, p. 19).

${ }^{21}$ Ao contrário do que algumas pessoas pensam a Realpolitik de Bismarck (1870-1890) não era imperialista, pois o seu sistema bismarckiano de alianças estava voltado apenas para a Europa com vistas a assegurar o equilíbrio de poder europeu e evitar o cerco do país pela França e seus aliados numa aliança anti-alemã. Os mais recentes defensores do chanceler alemão entre os historiadores acadêmicos têm demonstrado exaustivamente e com precisão "o caráter limitado das ambições de Bismarck para a Alemanha, seu desgosto pelo fanatismo nacionalista, sua aversão a guerras preventivas, e sua batalha sem fim para manter o Estado-Maior refreado" (PALMER, Alan Warwick. Bismarck. Brasília: Editora UNB, 1982, p. 268).

${ }^{22}$ MACMILLAN, Margaret. A Primeira Guerra Mundial. São Pulo: Globo Livros, 2014, p. 97.

${ }^{23}$ CARVALHO, Elyseo de. O factor geographico na política brasileira. Rio de Janeiro: S.A. Monitor Mercantil, 1921, p. 12.
} 
história, e a segunda, da obra de Friedrich Ratzel, $O$ mar como fonte de grandeza das nações, publicada em alemão, em 1900.

As ideias de Mahan e Ratzel, de que o mar é indicativo de que o país deve investir na força naval com vistas a projetar poder em escala mundial, contribuíram para a Alemanha tornar-se o berço do pensamento geopolítico. Os estrategistas alemães perceberam a partir dessas duas obras que o espaço onde ocorre a política dos Estados é no território. Para Ratzel, não há Estado sem território. Por isso mesmo, é que as suas análises políticas se distinguem dos cientistas políticos, pelo fato de ele geografizá-las.

Como o Estado não é concebível sem território e sem fronteiras, constitui-se bastante rapidamente uma geografia política, e ainda que nas ciências políticas em geral se tenha perdido frequentemente de vista a importância do fator espacial, da situação etc., considera-se, entretanto como fora de dúvida que o Estado não pode existir sem solo. ${ }^{24}$

Deste modo, a Weltpolitik alemã era, na verdade, uma Geopolitik devido à valorização do território na política do Estado. Para Ratzel, a Geografia deveria servir de guia para orientar "cientificamente" a política externa dos países. A sua tese de que “espaço é poder" está inequívoca na sua afirmação "um povo regride quando perde território. Ele pode contar com menos cidadãos e conservar ainda muito solidamente o território onde se encontram as fontes de sua vida. Mas se seu território se reduzir é, de maneira geral, o começo do fim" 25 .

Segundo André Martin, a chave das proposições de Ratzel encontra-se na sua concepção biológica do Estado. Para ele, "dado que o Estado é um organismo vivo e as fronteiras ou limites são partes integrantes e inseparáveis desse organismo elas estão sujeitas, portanto, a alterações permanentes" ${ }^{26}$. Dentre as suas importantes contribuições, destacam-se também as Sete Leis do Crescimento Espacial dos Estados $^{27}$ :

1. As dimensões do Estado crescem com sua cultura;

2. O crescimento dos Estados segue outras manifestações do crescimento dos povos, que necessariamente devem preceder o crescimento do Estado;

\footnotetext{
${ }^{24}$ RATZEL, Friedrich. O Solo, a Sociedade e o Estado. Revista do Departamento de Geografia, São Paulo, v. 2, nov. 1983, p. 93. Disponível em: 〈http://revistas.usp.br/rdg/article/view/47081 >. Acesso em: 26 jul. 2016.

25 Ibidem, p. 94.

${ }^{26}$ MARTIN, André Roberto. Op. cit., 1992, p. 42.

27 RATZEL. Friedrich. As leis do crescimento espacial dos Estados. In: MORAES, Antonio Carlos Robert (Org.) e FERNANDES, Florestan. (Coord.). Ratzel. São Paulo: Ed. Ática, 1990, p. 177-90.
} 
3. O crescimento do Estado procede pela anexação dos membros menores ao agregado;

4. As fronteiras são o órgão periférico do Estado, o suporte e a fortificação de seu crescimento, e participam de todas as transformações do organismo do Estado;

5. No seu crescimento, o Estado esforça-se pela delimitação de posições politicamente valiosas.

6. Os primeiros estímulos ao crescimento espacial dos Estados vêm-lhes do exterior;

7. A tendência geral para a anexação e fusão territoriais transmite-se de Estado a Estado, e cresce continuamente de intensidade.

De acordo com Meira Mattos, a primeira lei de Ratzel aborda a cultura, no seu sentido amplo de civilização, e tem sido o maior instrumento de irradiação de poder, como, por exemplo, a expansão da cultura mesopotâmica, da egípcia, da grega e da romana e, na atualidade, da cultura ocidental ${ }^{28}$. Na segunda lei, Ratzel cita três indicadores de crescimento do Estado: o comércio, as ideias e o proselitismo missionário. Para ele, esses fatores precedem o alargamento do horizonte geográfico do Estado $^{29}$.

Na terceira lei, “o Estado nunca está em repouso. Um contínuo efluxo sobre suas fronteiras transforma-o em um ponto de partida para expedições de conquista, cercado por um cinturão de terras despovoadas e desoladas" ${ }^{30}$. Na quarta lei, Ratzel apresenta a tese organicista do Estado, ou seja, ele faz uma analogia do Estado como um ser vivo, "reconhecendo as fronteiras, também, como um organismo vivo, dinâmico e forte, que materializará os acréscimos territoriais do Estado"31.

Já na quinta lei, os Estado não crescem aleatoriamente, mas buscam ampliar as suas áreas de influências em territórios geoestratégicos. A sexta lei guarda relação com o conceito de "espaço vital" (Lebensraum) ${ }^{32}$, ou seja, os Estados vão buscar anexar mais

\footnotetext{
${ }^{28}$ MATTOS, Carlos de Meira. Geopolítica e Modernidade. In: MATTOS, Carlos de Meira. Geopolítica. Rio de Janeiro: Editora FGV, v. 3, 2011, p. 51.

${ }^{29}$ RATZEL. Friedrich. Op. cit., 1984, p. 180.

${ }^{30}$ Ibidem, p. 184.

${ }^{31}$ MAFRA, Roberto Machado de Oliveira. Op. cit., 2006, p. 50.

32 Ratzel elaborou o conceito de "espaço vital" (em alemão, Lebensraum), este representaria uma proporção de equilíbrio entre a população de uma dada sociedade e os recursos disponíveis para suprir suas necessidades, definindo, portanto, suas potencialidades de progredir e suas premências territotiais
} 
território para plantar alimentos e obter mais recursos minerais para o desenvolvimento industrial ${ }^{33}$.

Por fim, a sétima lei apresenta a tese de que o espaço continuará sendo o campo de forças, onde se darão as relações de poder devido à crescente valorização do território como medida de poderio político.

Influenciados pela teoria ratzeliana do "espaço vital”, os geopolíticos alemães, no governo do Kaiser Guilherme II, não deixaram dúvidas a respeito das pretensões expansionistas do Estado germânico ao possuir colônias na África e Ásia. Ao fazerem isso, a Alemanha perturba a balança de poder na Europa que fora construída a duras penas por Bismarck, cujos desdobramentos foram a Primeira Guerra Mundial, em 1914.

No debate entre os geógrafos e os cientistas políticos, o termo Geografia Política assumiu um sentido de "neutralidade científica" e contemplação de mundo. Já a Geopolítica está voltada para a "ação e transformação".

Como explicou o geógrafo Wanderley Messias:

\begin{abstract}
Descartadas as confusões e dissimulações em torno do rótulo, pode-se afirmar com relativa segurança que a geopolítica, tal como foi exposta pelos principais teóricos, é antes de tudo um subproduto e um reducionismo técnico e programático da geografia política, na medida em que se apropria de parte de seus postulados gerais, para aplicá-los na análise de situações concretas interessando ao jogo de forças estatais projetado no espaço ${ }^{34}$.
\end{abstract}

De acordo com o geopolítico brasileiro André Martin, "não existe autor de Geopolítica ou de Geografia Política que não reconheça em Ratzel o fundador deste novo ramo do conhecimento científico". Ele é o pai da Geografia Política, “cujo objeto e teoria ele desenvolve em duas obras fundamentais: Politische Geographie, editada pela primeira vez em 1897, e $O$ mar como fonte de grandeza das nações cuja primeira edição em alemão é de 1900"35. Até mesmo Claude Raffestin, crítico ferrenho de uma geografia do Estado - que considera o poder unidimensional - reconhece que a obra ratzeliana lançou as bases da geografia política ${ }^{36}$.

(MORAES, Antonio Carlos Robert. Geografia: pequena história crítica. São Paulo: Annablume, 2007, p. 70).

33 ALBUQUERQUE, Edu Silvestre de. Geopolítica do Brasil: a construção da soberania nacional. São Paulo: Atual, 2006, p. 7.

${ }^{34}$ COSTA, Wanderley Messias da. Geografia Política e Geopolítica: Discursos sobre o Território e o Poder. 2. ed. São Paulo: Edusp, 2013, p. 55.

${ }^{35}$ MARTIN, André Roberto. Op. cit., 2004, p. 21.

${ }^{36}$ RAFFESTIN, Claude. Por uma geografia do poder. Tradução Maria Cecília França. São Paulo: Ática, 1993, p. 13. 
A contribuição de Ratzel foi importantíssima para "o deslocamento do foco central das pesquisas geográficas da 'paisagem natural' para a relação 'homem meio', tese defendida no livro Anthropogeographie, surgido em 1882"37. Na concepção de Ratzel, não se poderia compreender uma ciência excluindo o elemento humano. Segundo Elysio de Carvalho, "não estudamos a terra pela terra, senão pelo homem, e para o homem. É o homem o objeto da geografia e não propriamente a terra. Só queremos saber da terra aquilo que interessa ao conhecimento do homem" 38 . Ainda nessa linha, Moraes afirma que "a importância maior de sua proposta reside no fato de haver trazido, para o debate geográfico, os temas políticos e econômicos, colocando o homem no centro das análises"39.

Ademais, uma leitura atenta das principais obras ratzelianas, como Antropogeografia (1882) e Geografia Política (1897), demonstra que Ratzel, diferente do que alguns dizem, apenas falava numa "influência" do ambiente sobre o homem, e não em determinismo geográfico ${ }^{40}$. Aliás, ele criticava essa abordagem segundo o geógrafo brasileiro Antônio Carlos Robert Moraes:

\begin{abstract}
Ratzel foi um crítico do determinismo simplista, o qual em sua opinião prestou um desserviço à geografia ao tentar explicar de imediato - e por uma via especulativa, sem base empírica - a complexa questão das influências das condições naturais sobre a humanidade. Ele chegou a tecer críticas contundentes à ideia "obscura" de ser o homem "um produto do meio" 41 .
\end{abstract}

Para Ratzel, "o que importava era avaliar como o meio natural influenciava o desenvolvimento das sociedades"42. A sua teoria ambientalista, contida na obra Antropogeografia, muito polêmica, foi distorcida, de forma um tanto simplista, ficou conhecida como "determinismo geográfico" 43 . Segundo André Martin, dentre as muitas contribuições que Ratzel deixou para a Geografia Política, ele considera cinco as mais importantes ${ }^{44}$ :

1) A ideia de que o objeto de estudo da Geografia Política deve ser a relação "Estado-território-sociedade";

\footnotetext{
${ }^{37}$ MARTIN, André Roberto. Op. cit., 2004, p. 21.

${ }^{38}$ CARVALHO, Elysio de. Op. cit., 1921, p. 14.

${ }^{39}$ MORAES, Antonio Carlos Robert. Op. cit., 2007, p. 74.

${ }^{40}$ ALBUQUERQUE, Edu Silvestre de. Op. cit., 2006, p. 9.

${ }^{41}$ MORAES, Antonio Carlos Robert. Introdução. In: MORAES, Antônio Carlos Robert (Org.) e FERNANDES, Florestan (Coord.). Ratzel. São Paulo: Ed. Ática, 1990, p. 10.

${ }^{42}$ MARTIN, André Roberto. Op. cit., 1992, p. 14.

${ }^{43}$ Ibidem, p. 21.

${ }^{44}$ Ibidem, p. 23.
} 
2) A teoria de que cada Estado tem sua vida política condicionada pelos fatores "espaço" (entendido como a área ocupada por um Estado), e "posição" (este "espaço" relacionado a todos os outros, isto é, a superfície da terra);

3) A tese de que "espaço é poder", isto é, o "espaço" não é visto apenas como suporte ou como veículo das forças políticas, mas ele é em si mesmo considerado uma poderosa força política;

4) A ideia de que o poder mundial sempre se repartiu entre potências "marítimas" e "terrestres", e finalmente;

5) A sua conclusão de que só o poder marítimo conduz ao verdadeiro poder mundial, uma vez que a massa líquida dos oceanos contém a massa sólida dos continentes, e estes últimos estão separados entre si, ao passo que os oceanos estão interligados.

Com base nesses cinco postulados, a Geografia Política firmou-se como um novo ramo da Geografia, vindo a se consolidar como uma nova "ciência". Suas obras influenciaram uma série de autores que lhe sucederam como Rudolf Kjellén, Halford J. Mackinder e Karl Haushofer, repercutindo também, no Brasil, no início do século XX.

\subsection{A origem e os precursores da geopolítica brasileira}

Nas décadas de 1920 e 1930, surgiram os primeiros estudos sobre a geopolítica no Brasil. Foram os anos em que a geopolítica começou a ser sistematizada ${ }^{45}$. Especialmente nos trabalhos de Everardo Backheuser que, apesar de não ter sido "o primeiro a ter pensado ou escrito trabalhos de cunho geopolítico por aqui, no entanto, a

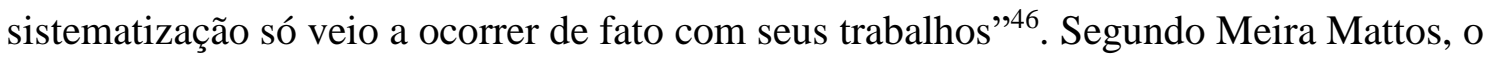
professor Backheuser foi um exímio "teórico da geopolítica brasileira, deu-lhe um método, sistematizou-a" ${ }^{47}$. Por essa razão, ele é considerado o pai ${ }^{48}$ e mestre ${ }^{49}$ da

45 MIYAMOTO, Shiguenoli. O Pensamento Geopolítico Brasileiro (1920-1980). Dissertação de Mestrado apresentada ao Departamento de Ciências Sociais (área de Ciência Política) da Faculdade de Filosofia, Letras e Ciências Humanas da Universidade de São Paulo. São Paulo, 1981, p. 48.

${ }^{46}$ ANSELMO, Rita de Cássia Martins de Souza; BRAY, Silvio Carlos. Geografia e Geopolítica na formação nacional brasileira: Everardo Adolpho Backheuser. In: GERARDI, Lúcia Helena de Oliveira; MENDES, Iandara Alves. (Org.). Do natural, do Social e de suas Interações: Visões Geográficas. 1. ed. Rio Claro - SP: Programa de Pós-Graduação em Geografia UNESP/ AGETEO, 2002, p. 110.

${ }^{47}$ MATTOS, Carlos de Meira. Op. cit., 2011, p. 184.

${ }^{48}$ Ibidem, p. 184.

${ }^{49}$ COUTO E SILVA, Golbery do. Geopolítica do Brasil. Rio de Janeiro: José Olympio Editora, 1967, p. 66. 
geopolítica brasileira. Ademais, dentre todos os precursores da Geopolítica brasileira, ele é o que foi "fortemente influenciado por Ratzel" 50 e o que "melhor se adapta à corrente 'organicista' dessa disciplina" 51 .

Embora o estudo da Geopolítica tenha sido introduzido no Brasil há apenas um século, quando Elysio de Carvalho ${ }^{52}$; Everardo Backheuser ${ }^{53}$; Carlos Delgado de Carvalho ${ }^{54}$ e Mario Travassos ${ }^{55}$ publicaram os primeiros trabalhos sobre o tema, o seu significado já havia sido explorado muito antes no país, desde o século XV, quando os portugueses utilizaram o sistema tordesilhano constituindo o núcleo geohistórico do Brasil $^{56}$. Destarte, a sistemática geopolítica portuguesa, empregada durante a formação territorial do Brasil, especialmente no século XVIII, garantiu a dimensão continental do nosso país. Com destaque ao eminente diplomata brasileiro da coroa portuguesa Alexandre de Gusmão, distinguiu-se por sua visão e capacidade de definir interesses estratégicos de longo prazo. Desempenhou um papel crucial nas negociações do Tratado de Madrid, assinado em 1750. Ele não apenas definiu os limites entre os domínios coloniais portugueses e espanhóis na América do Sul, como também consagrou o princípio do uti possidetis, uma das bases da doutrina jurídica e da política de fronteiras do Brasil.

Para compreender a origem da geopolítica no Brasil, será importante fazer uma breve digressão para a conjuntura política da Península Ibérica, na segunda metade do século XIV, conforme apresentado no mapa 1.

\footnotetext{
50 BECKER, Bertha Koiffmann. A Geografia e o Resgate da Geopolítica. Revista Brasileira de Geografia, Rio de Janeiro, v. 50, n. 2, número especial, p. 99-126, 1988.

${ }^{51}$ MARTIN, André Roberto. Brasil, Geopolítica e Poder Mundial: o anti-Golbery. Tese de LivreDocência apresentada ao Departamento de Geografia da Faculdade de Filosofia, Letras e Ciências Humanas da Universidade de São Paulo. São Paulo, 2007, p. 37.

${ }^{52}$ Elysio de Carvalho escreveu os livros, Brasil Potência Mundial - Inquérito sobre a Indústria Siderúrgica no Brasil, em 1919; O fator geográfico na política brasileira, em 1921.

${ }^{53}$ Dentre as principais contribuições de Everardo Backheuser para o estudo da Geopolítica salienta-se: A Estrutura Política do Brasil. Notas Prévias, em 1926; Problemas do Brasil - Estrutura geopolítica, em 1933; A Geopolítica Geral e do Brasil, em 1955.

${ }_{54}^{54}$ Nas obras de Delgado de Carvalho, destaca-se: Introdução à Geopolítica, publicada em 1929.

${ }^{55}$ O principal livro de Mario Travassos na área da geografia política foi Projeção Continental do Brasil, em 1931. Essa obra foi fundamentada num primeiro ensaio do autor intitulado Aspectos Geográficos SulAmericanos, também publicada em 1931.

56 CASTRO, Therezinha de. Nossa América: geopolítica comparada. Rio de Janeiro: Biblioteca do Exército, 1994, p. 132.
} 


\section{Mapa 1: Núcleo Geohistórico do Meridionalismo}

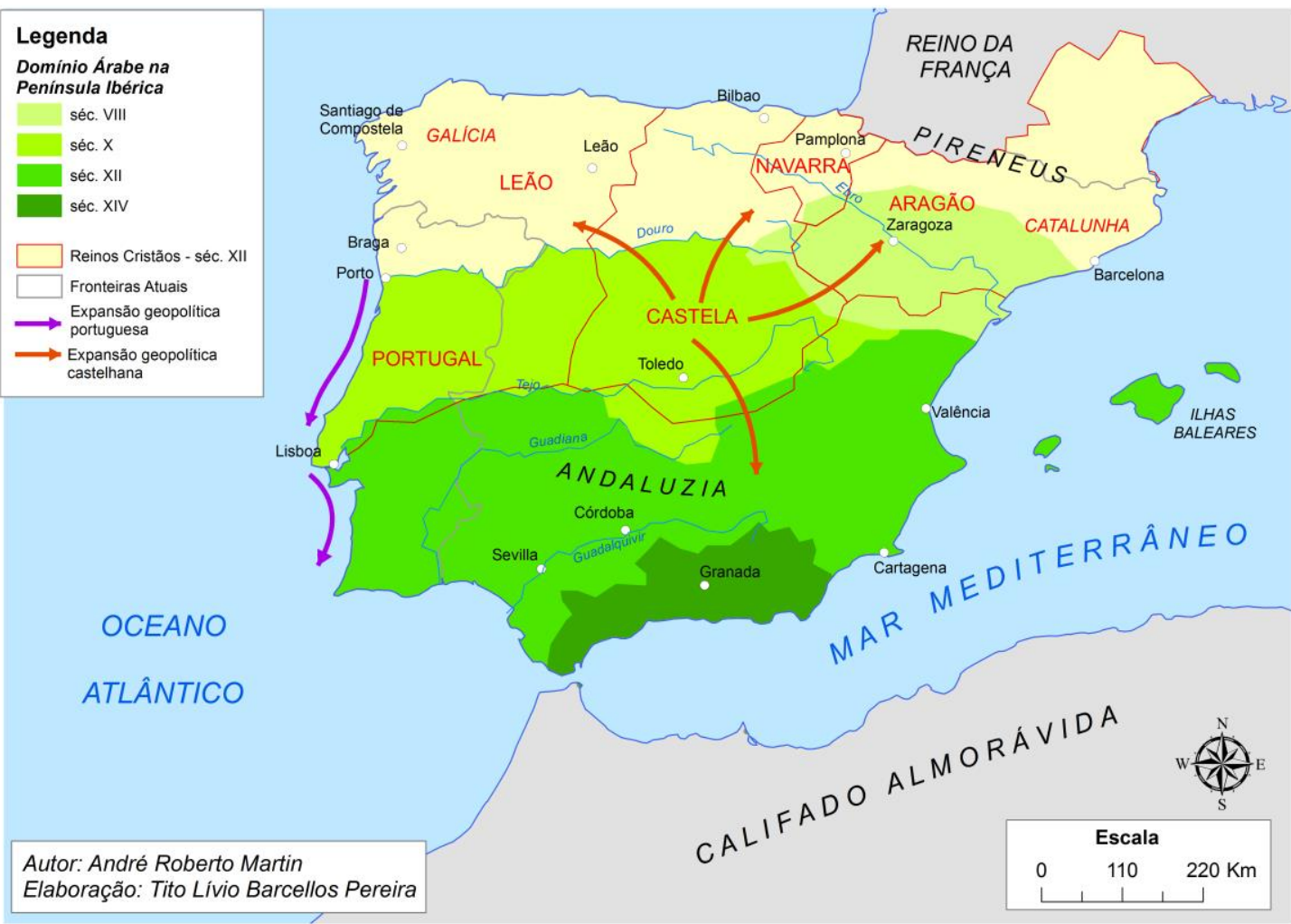

Nessa época, a Península Ibérica estava dividida em quatro Estados cristãos e um mulçumano. No centro, Castela, no oriente, Aragão, no ocidente, Portugal, no norte, Navarra; estes eram núcleos geopolíticos cristãos; e Granada ao sul, mulçumano. Dentro do enfoque geopolítico desse conjunto peninsular, Castela, no epicentro, procurava, em seu proveito, unificar toda a área.

Conforme observou Therezinha de Castro:

Em consequência, uma vez efetuada a sua diretriz mediterrânea, com a união Castela/Aragão (1469), partiam os castelhanos para melhor posicionamento na rota Gibraltar, subtraída aos mouros em 1462, o que só conseguiriam efetivar 30 anos depois, ao anexar Granada (1492). A partir de então, punhase frente a frente com Portugal, já detentor de Ceuta, Tânger e Arzila, no entroncamento Mediterrâneo/Atlântico. Estrangulada no norte pelos Pirineus, e geopoliticamente cercada na Península Ibérica, nada mais restaria à Navarra do que o processo de amalgação com Castela, que ocorreria em 1512. Isolada na periferia, porém, com posicionamento geoestratégico no Atlântico, Portugal escaparia da política expansionista de Castela, no momento em que D. João I vencia a Batalha de Aljubarrota $(1385)^{57}$.

57 CASTRO, Therezinha de. Do Infante a Tordesilhas - Sistemática Geopolítica. Revista do Instituto Geográfico Histórico Militar do Brasil, n. 81, 1995, p. 54. 
Essa conjuntura política da Península Ibérica implicou na primeira revolução burguesa no mundo, ainda no século XIV, conhecida como Revolução de Avis (138385), quando a burguesia lusa, em aliança com os camponeses, conseguiu levar ao trono D. João de Avis (rica família de armadores). A partir de então, ele passou a chamar-se D. João I. Embora Castela fosse a potência hegemônica regional, ela não conseguiu anexar Portugal. A vitória lusitana na Batalha de Aljubarrota, em 14 de agosto de 1385, contra o reino de Castela, teve três consequências políticas: a) consolidou Portugal como o primeiro Estado Moderno europeu; b) pôs fim às ambições de Castela em anexar Portugal e c) a partir daí surgiu a "ilustre geração" de personagens que contribuíram para a glória de Portugal, a começar pelo próprio D. João I, devido à vitória na Batalha de Aljubarrota, seguido por seu filho, o infante D. Henrique, artífice da diretriz geopolítica meridionalista portuguesa, começando pela tomada de Ceuta, no norte da África, em 1415, resultando na expansão ultramarina portuguesa no Hemisfério Sul.

Therezinha de Castro destaca que o Poder Marítimo consagrado pela sistemática geopolítica do Infante D. Henrique ficava com Portugal. Por sua vez, o centripetismo castelhano induziria esse Reino ao Poder Terrestre ${ }^{58}$.

Ocupados com a unificação dos reinos locais na Península Ibérica e com a expulsão dos árabes, na Guerra da Reconquista, que só se conclui em 1492, os espanhóis começaram sua expansão marítima mais tarde. Já os portugueses estabeleceram a sua diretriz geopolítica meridionalista em três frentes geoestratégicas: Ceuta, Atlântico Sul e Oceano Índico. Diferentemente de Castela e França, que precipitaram uma "varredura Oeste-Leste".

A primeira frente geoestratégica foi a tomada de Ceuta, em 21 de agosto de 1415, liderada pelo Infante D. Henrique, ao lado de seus outros dois irmãos, Pedro e Duarte. A conquista da cidade, na costa do Marrocos, era importante para o futuro do país, pois visava garantir a defesa da classe burguesa instalada nos portos portugueses e a transformação de Lisboa num empório comercial seguro. Localizada sobre sete colinas, diante do porto de Algeciras, Ceuta era ponto de apoio dos corsários árabes, no ataque à Península Ibérica, de auxílio ao Reino de Granada, podendo ainda se transformar numa futura "cabeça de ponte" na reconquista do perdido território algarvio. Daí a conquista dessa importante cidade pelos portugueses, no norte da África.

\footnotetext{
${ }^{58}$ Ibidem, p. 55.
} 
Sendo assim, Portugal dava seu primeiro grande passo para a sua expansão ultramarina, tendo como núcleo diretor de sua expansão Sagres ${ }^{59}$.

O Atlântico Sul foi a segunda frente geoestratégica, concretizando-se através da expedição de Bartolomeu Dias que, navegando por esse oceano, chegaria ao extremo sul da costa africana, ao Cabo das Tormentas, em 1488, batizado por D. João II de Boa Esperança. Por fim, a terceira frente foi o Oceano Índico, cuja expedição de Vasco da Gama cruzou o oceano Atlântico e Índico, culminando na sua descoberta do caminho marítimo para as Índias, em 1498, executando, assim, a diretriz geopolítica meridionalista portuguesa que buscava sair da periferia de Castela, na Península Ibérica, para tornar-se o centro do mundo a partir do controle da rota das especiarias.

Sem dúvida nenhuma, a superioridade portuguesa, em conhecimento geográfico, utilizada na "Escola de Sagres", garantiu a primazia nas conquistas ultramarinas e possibilitou evitar uma guerra com a Espanha ${ }^{60}$, o que era iminente depois de Cristovão Colombo, sob a égide de Castela, atingir a América, em 1492.

A notícia da viagem de Colombo trouxe preocupações à Coroa Portuguesa. As viagens espanholas poderiam ameaçar o projeto do país de atingir as Índias contornando a África? Portugal com base em várias Bulas Papais e até em cláusulas estipuladas por convenção Real alegava serem suas as terras. Para evitar o confronto entre os dois Reinos Cristãos, o Papa Alexandre VI entraria em cena propondo, primeiramente, um meridiano a 100 léguas de Cabo Verde, para delimitar as terras que pertenciam à Espanha (Bula Inter Coetera, de 4 de maio de 1493) ${ }^{61}$. Os termos da bula desagradaram à Coroa Portuguesa, e o rei D. João II de Portugal protestou junto à Cúria Romana e, depois de exaustivas negociações diplomáticas, foi assinado o Tratado de Tordesilhas, em 1494 , que estabeleceu um novo meridiano a 370 léguas das ilhas de Cabo Verde ${ }^{62}$.

As negociações entre Portugal e Espanha, que resultaram na terceira e última proposta para regionalizar o espaço mundial, foram abordadas pelo historiador Leonardo Dantas Silva:

\footnotetext{
${ }^{59}$ Ibidem, p. 58.

60 SILVA, Leonardo Dantas. Tordesilhas: A divisão do Brasil antes de Pedro Álvares Cabral. In: ANDRADE, Manuel Correia de. (Org.). Tordesilhas: um marco geopolítico. Recife: Funjaj, Ed. Massangana, 1997, p. 26-7.

${ }^{61}$ CASTRO, Therezinha de. Op. cit., 1995, p. 65.

${ }^{62}$ MATTOS, Carlos de Meira. Geopolítica e teoria de fronteiras: fronteiras do Brasil. Rio de Janeiro: Bibliex, 1990, p. 60.
} 
A tenacidade de D. João II, defendendo inicialmente o paralelo das canárias e depois, quando tal solução tornou-se insustentável, o alargamento da raia proposta para 370 léguas, só é justificada por dois motivos: garantir para Portugal a navegação no atlântico Meridional, sem a intromissão de qualquer natureza, e a incorporação à Coroa portuguesa das terras situadas no sudoeste do Atlântico Sul de cuja existência parecia ter convicção ${ }^{63}$.

Diferentemente de Cristovão Colombo que chegou às Américas, em 1492, acreditando haver aportado no arquipélago asiático, os portugueses já sabiam da existência de terras a oeste do Atlântico, e que elas não eram as Índias, diga-se de passagem $^{64}$. Não é por acaso que a terceira e última proposta do alargamento de 100 para 370 léguas no Meridiano de Tordesilhas agradou aos lusitanos.

Como explica Therezinha de Castro:

O Tratado de Tordesilhas indica também claramente que as diretrizes geopolíticas do governo português se pretendiam a um território-base na América do Sul. Isto porque se o objetivo fosse unicamente o caminho marítimo para as Índias, bastavam, mesmo na imprecisão, as 100 léguas da bula do Papa Alexandre VI ${ }^{65}$.

Portugal queria um ponto de apoio do outro lado do Oceano Atlântico. Imitando o Mare Clausum romano, os portugueses inventaram o termo Atlântico Sul. Enquanto Portugal aponta em direção à rota do Sul para chegar às Índias, a Espanha procuraria a nascente pela rota do poente. Até mesmo os franceses tentarão o caminho para a China a partir do estuário do rio São Lourenço. Após a divulgação da existência de terras na borda ocidental do Oceano Atlântico, nada mais restava a Portugal do que negociar, diplomaticamente, com Castela, a assinatura do Tratado de Tordesilhas, como se pode ver no mapa 2.

\footnotetext{
${ }^{63}$ SILVA, Leonardo Dantas. Op. cit., 1997, p. 30.

${ }^{64}$ As navegações portuguesas para o oeste do Atlântico eram realizadas em sigilo, até para não despertar a cobiça de outros países europeus, notadamente ingleses, franceses e holandeses. As expedições de Portugal são comprovadas em documentos, datados de 1470. Desde essa época o pau-brasil, principal riqueza explorável no litoral brasileiro, já estava sob o monopólio da Coroa Portuguesa (CASTRO, Therezinha de. Op. cit., 1995, p. 68). A carta náutica de 1424, do cartógrafo veneziano Zuane Pizzigane, revela a representação precoce do continente Americano. O mapa também identificava a ilha Brazil, a Oeste da Irlanda. Segundo Armando Cortesão, no século XV, a cartografia em Portugal era provavelmente de influência genovesa (CORTESÃO, Jaime. Os descobrimentos portugueses. Lisboa: Livros Horizonte, v. II, 1975, p. 346, 350).

${ }^{65}$ CASTRO, Therezinha de. Atlas-texto de geopolítica do Brasil. Rio de Janeiro: Capemi Editora, 1981, p. 12.
} 
Mapa 2: Geopolítica de Tordesilhas segundo Therezinha de Castro

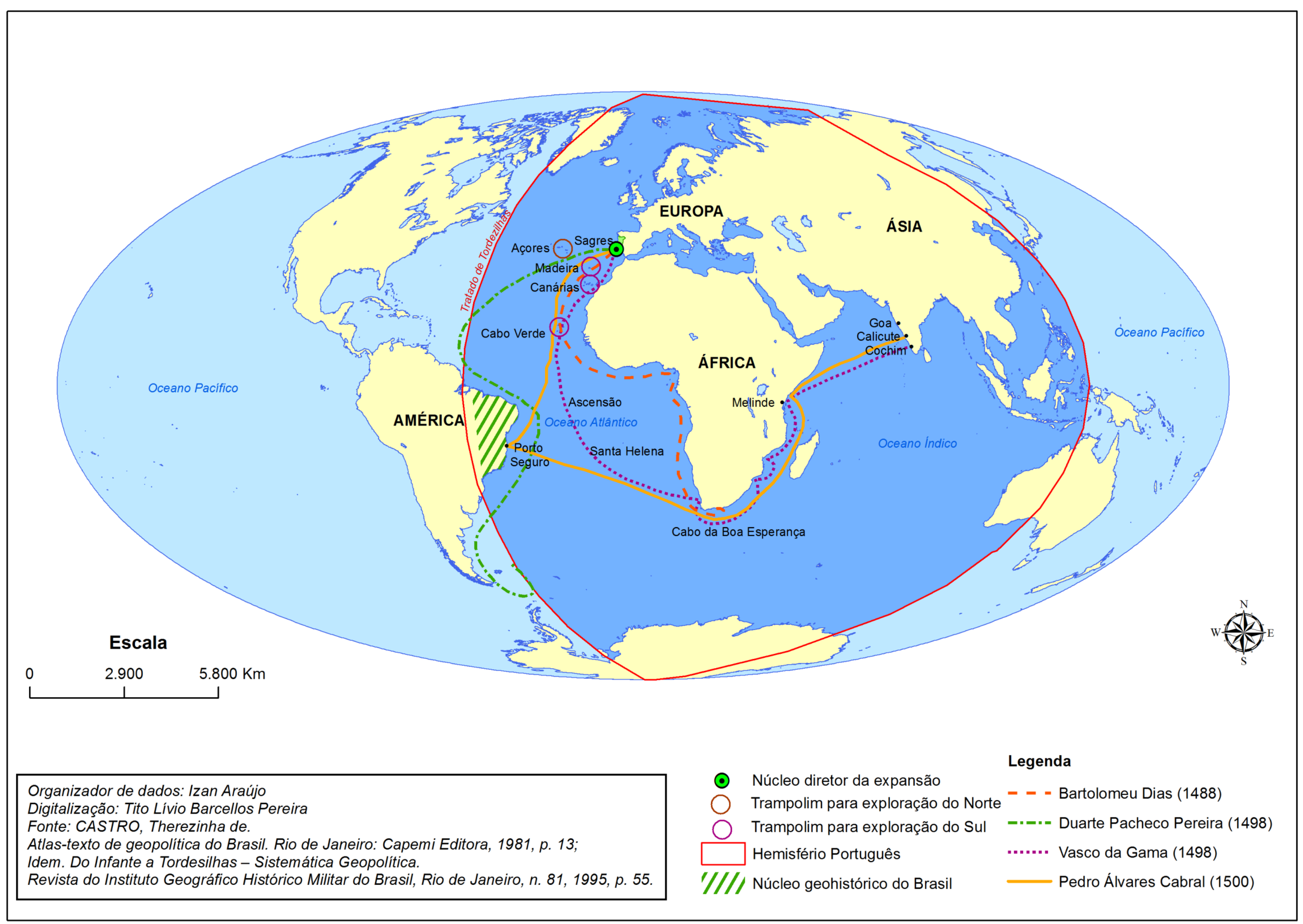


O mapa 2 da geógrafa brasileira Therezinha de Castro mostra a diretriz geopolítica "meridionalista" portuguesa, inaugurada com o Infante D. Henrique. A Coroa Portuguesa conquistaria também um território base de 2,8 milhões de $\mathrm{km}^{2}$, na borda ocidental do Atlântico Sul, que viria ser o núcleo geohistórico do futuro Estado brasileiro.

Já na segunda metade do século XVI, o Império português era imenso, tinha colônias em vários continentes, mas Portugal já não estava sozinho nos caminhos marítimos que descobriu ${ }^{66}$. Em 1580, com a morte do cardeal D. Henrique, Rei de Portugal, sem deixar herdeiros diretos, passou-se o trono português para as mãos do Rei da Espanha, Filipe II, originando a União Ibérica, que duraria até $1640^{67}$. Para André Martin, o período da união das Coroas Ibéricas (1580-1640) "foi fundamental para que o Brasil adquirisse sua configuração atual, pois foi nesse interregno que Tordesilhas deixou efetivamente de existir, permitindo, sobretudo, a penetração pela Bacia Amazônica"68. Essa expansão foi decorrente do desenvolvimento econômico da colônia e do interesse geopolítico da Coroa Portuguesa. Os caminhos foram abertos pelas missões religiosas empreendidas pelos jesuítas; a caça aos índios feita pelos bandeirantes; a busca de riquezas minerais; a pecuária e o comércio de mercadorias que, à época, eram feitos pelos tropeiros. Esses são os principais fatores que proporcionaram a conquista de novas terras pelos colonos ${ }^{69}$.

Depois da União Ibérica, surgem litígios fronteiriços entre as duas monarquias, pois ambas já não observavam mais o Tratado de Tordesilhas, embora os portugueses tivessem ocupado a região norte do Brasil, antes mesmo dos espanhóis, através da construção de diversos Fortes, dentre estes se destacando o Forte do Presépio, posicionado geoestrategicamente na foz do rio Amazonas, em Belém do Pará, construído no ano de 1616. Por outro lado, no sul do país, os espanhóis chegaram primeiro, mais exatamente na bacia Platina, ocupando a foz do rio da Prata por meio da

\footnotetext{
${ }^{66}$ É nesse contexto que o padre português Fernando Oliveira escreve a sua obra a Arte da Guerra do Mar, publicada em 1555. No livro, ele aborda a dimensão estratégica dos assuntos navais. Considera que os armamentos garantem a paz e não favorecem a guerra. Segundo o autor, "para que isso favorecem as armas, as quais não são tão contrárias da paz como parecem, antes elas defendem na paz como os cães defendem as ovelhas, posto que pareçam contrárias delas" (OLIVEIRA, Fernando. A Arte da Guerra do Mar: estratégia e guerra naval no tempo dos descobrimentos. Lisboa/Portugal: Editora 70, 2008, p. 12).

${ }^{67}$ ANDRADE, Manuel Correia de. Geopolítica do Brasil. São Paulo: Ática, 1995, p.15.

${ }^{68}$ MARTIN, André Roberto. Op. cit., 1992, p. 83.

${ }^{69}$ DIAS, Demosthenes de Oliveira. Formação Territorial do Brasil: origem e evolução. Rio de Janeiro: Gráfica Olímpica, 1956, p. 29.
} 
construção da cidade portuária de Buenos Aires, em $1580^{70}$. Portugal ainda esboçou uma reação, em 1680, com a fundação da Colônia de Sacramento, posicionada na margem oposta do rio da Prata, contudo, o governo de Buenos Aires agiu violentamente, mobilizando 250 soldados e 3 mil índios das Reduções Jesuíticas, para assaltar a Colônia do Sacramento, quase reduzida a escombros, poucos meses depois de sua fundação ${ }^{71}$. Os portugueses vão retomar esse território pela via diplomática através do Tratado de Utrecht ${ }^{72}$, em 1713. Como se pode observar, o núcleo geohistórico da rivalidade entre Brasil e Argentina origina-se, de certo modo, desde a segunda metade do século XVII, quando Portugal e Espanha disputavam entre si o controle da margem oriental do rio da Prata, devido à ausência de limites fronteiriços definidos entre as duas metrópoles ibéricas. A Colônia do Sacramento é o ponto nevrálgico da rivalidade entre portugueses e espanhóis que se desdobra em dois planos: o militar e o diplomático. Cada vitória militar dos espanhóis correspondia uma vitória diplomática dos portugueses $^{73}$.

Nesse contexto, surge um dos precursores da geopolítica brasileira, o diplomata brasileiro da Coroa Portuguesa Alexandre de Gusmão. Ele destaca-se pelo papel crucial que desempenhou nas negociações com a Espanha. Para resolver essa longa divergência, pela via diplomática, recorreu à cláusula do Tratado de Utrecht, segundo a qual a Coroa espanhola poderia propor aos portugueses a troca da Colônia de Sacramento por qualquer compensação territorial ${ }^{74}$. Tendo em vista que a Colônia do Sacramento tinha um posicionamento geoestratégico na bacia do Prata os espanhóis aceitaram negociá-la em troca de uma compensação territorial a Portugal ${ }^{75}$.

No dia 13 de janeiro de 1750 foi celebrado por Portugal e Espanha o Tratado de Madri. O acordo permitiu aos espanhóis se apoderarem da Colônia de Sacramento, que

\footnotetext{
${ }^{70}$ ALBUQUERQUE, Edu Silvestre de. Op. cit., 2006, p. 12.

${ }^{71}$ MONIZ BANDEIRA, Luiz Alberto. A expansão do Brasil e a formação dos Estados na Bacia do Prata: Argentina, Uruguai e Paraguai (da colonização à Guerra da Tríplice Aliança. 4. ed. Rio de Janeiro: Civilização Brasileira, 2012, p. 66).

${ }^{72} \mathrm{O}$ Brasil incorporou três quartos da bacia amazônica, e a conservou, porque a Inglterra, a fim de conter o avanço da França da região, conseguiu, ao negociar, em 1713, o Tratado de Utrecht, que o governo francês reconhecesse a soberania de Portugal sobre a Amazônia e se conformasse com somente a faixa que margeava o Oiapoque. A Coroa espanhola ainda restituiu aos portugueses a Colônia de Sacramento, cujo domínio manteram até 1750, quando com o Tratado de Madri foi trocado pelo território dos Sete Povos. (MONIZ BANDEIRA, Luiz Alberto. Op. cit., 2012, p. 65, 67).

${ }^{73}$ SOARES, Teixeira. História da Formação das Fronteiras do Brasil. Rio de Janeiro: Biblex, 1973, p. 280.

${ }^{74}$ RIO-BRANCO, Miguel Paranhos de. Alexandre de Gusmão e o Tratado de 1750. Brasília: Mec os Cadernos de Cultura, 1953, p, 30.

${ }^{75}$ SOARES, Teixeira. Op. cit., 1973, p. 282.
} 
era objeto de tanta cobiça; em troca os portugueses incorporaram a região referente a Sete Povos e das Missões, que havia sido colonizada primeiramente pelos espanhóis. Essas eram as únicas exceções ao princípio do uti possidetis ${ }^{76}$ utilizado como critério para o acordo. Entretanto, Castela não se deu por satisfeita em função de seus interesses hegemônicos na região. Os dois reinos ibéricos continuavam disputando o controle da margem oriental do rio da Prata. Para que esse litígio fronteiriço fosse resolvido, foi assinado, posteriormente, em 1777, o Tratado de Santo Ildefonso, pelo qual Portugal cedia a região dos Sete Povos e das Missões aos espanhóis que já possuíam, também, a Colônia do Sacramento. Assim, a Coroa espanhola passou a possuir o monopólio na bacia platina.

Dessa vez, foi a Coroa Portuguesa que não ficou satisfeita com o acordo. As negociações entre as duas metrópoles foram retomadas no início do século XIX, e concretizou-se definitivamente com o Tratado de Badajoz, celebrado em 1801, quando foi restabelecida a demarcação acertada em 1750, no Tratado de Madri. Consequentemente, os portugueses recuperaram a região de Sete Povos e das Missões, ou seja, o atual território do Rio Grande do Sul, onde é fixada a fronteira meridional do Brasil. Já os espanhóis mantiveram o domínio da região platina.

\footnotetext{
${ }^{76} \mathrm{O}$ princípio romano uti possidetis significa quem possui de fato, deve possuir de direito, ou seja, a "posse da terra para quem a ocupou e colonizou primeiro." (MATTOS, Carlos de Meira. Op. cit., 1990, p. 94).
} 
Mapa 3: Tratados que delimitaram as fronteiras do Brasil (1494-1801)

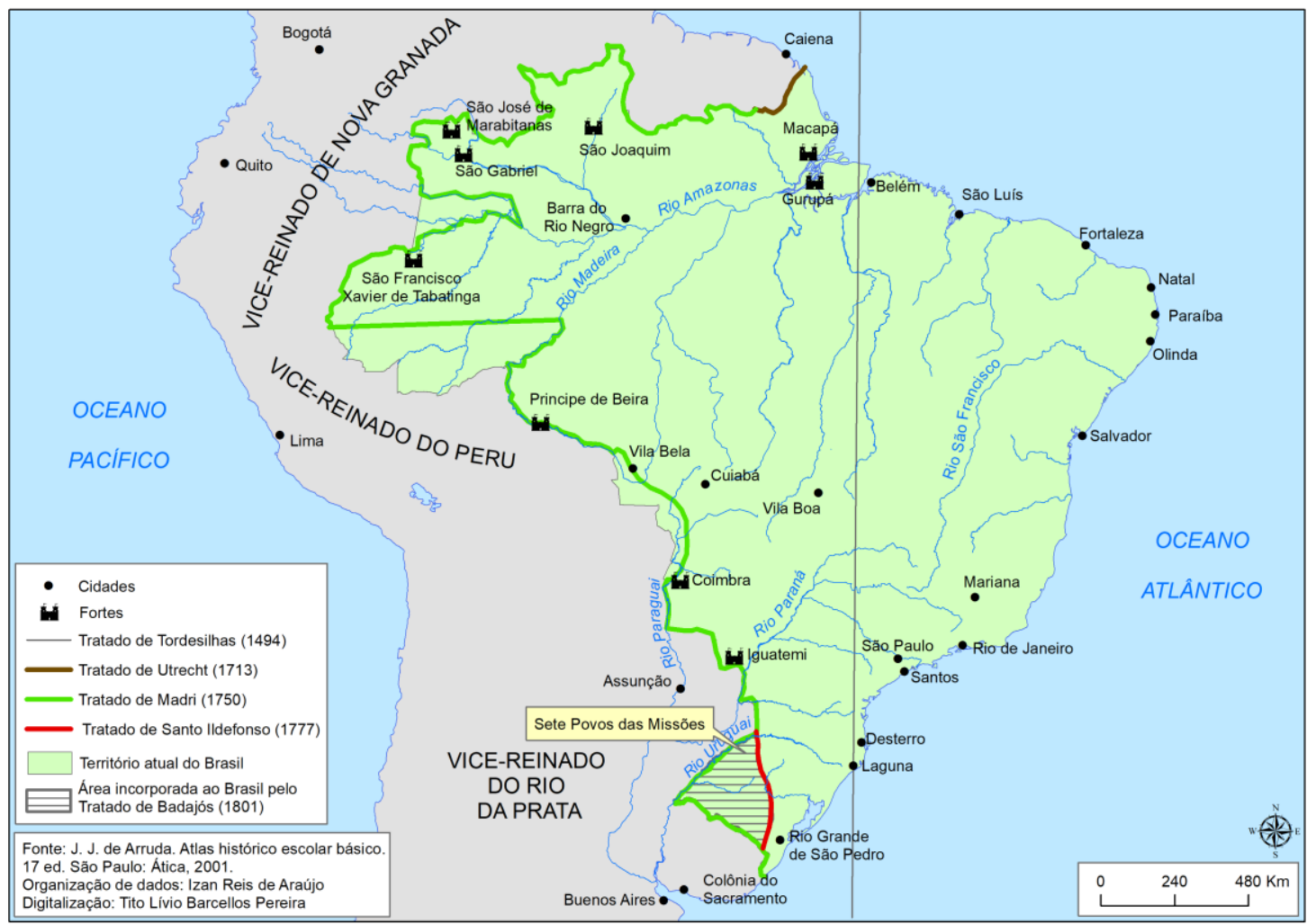

O mapa 3, acima, apresenta a expansão territorial da América portuguesa para além do limite delimitado pelo Meridiano de Tordesilhas. O mérito de Alexandre de Gusmão consiste em não apenas definir diplomaticamente os limites entre os domínios coloniais portugueses e espanhóis na América do Sul, mas, sobretudo, garantir a dimensão continental do futuro Estado brasileiro. Por isso mesmo é considerado não só um dos patronos da nossa diplomacia, ao lado do Barão do Rio Branco, como também o "precursor da geopolítica brasileira"77.

Depois de quase um século de rodadas de negociações diplomáticas, envolvendo os tratados de Utrecht (1713), Madrid (1750), Santo Ildefonso (1777) e Badajóz (1801), Meira Mattos aponta que "os limites máximos de dilatação fronteiriça tiveram que recuar em alguns pontos, mas o contorno geográfico de nosso território, em grandes linhas, foi mantido" ${ }^{\text {78. }}$.

No século XIX, com o advento do movimento independentista na América Latina, houve a necessidade de negociar novamente as nossas fronteiras, dessa vez com

77 BARRIOS, Miguel Ángel. Diccionário latinoamericano de seguridad y geopolítica. Buenos Aires: Biblos, 2009, p. 200; MARTIN, André Robero. Op. cit., 1992, p. 83.

${ }^{78}$ MATTOS, Carlos de Meira. Op. cit., 1990, p. 64. 
as novas repúblicas hispano-americanas vizinhas. Embora não houvesse grande controvérsia nas fronteiras norte e oeste na época em que a América do Sul era dominada pelas metrópoles ibéricas, após as independências, surgem problemas para a definição dos territórios. Os novos Estados aceitaram a herança espanhola que lhes cabia, mas tinham algumas reivindicações territoriais próprias, pois nem tudo estava claro nos tratados celebrados entre as cortes de Lisboa e Madrid, a fronteira na sua maior parte era desconhecida e despovoada ${ }^{79}$.

O caso brasileiro mais emblemático desses litígios fronteiriços foi o território do Acre. Passou a ganhar importância econômica entre o fïm do século XIX e o começo do século XX, devido à extração de látex pela seringueira - matéria-prima da região amazônica - e a comercialização da borracha, usada pela indústria automobilística internacional $^{80}$. A borracha que, em 1848, representava apenas 10,7\% dos produtos exportados, passou, em 1872, a 71,9\%. O comércio da borracha tornou-se um sustentáculo da economia brasileira - em seu auge significou quase $40 \%$ das receitas de exportação - quase se igualando ao café em importância ${ }^{81}$.

Embora o território pertencesse à Bolívia, a mão de obra brasileira, representada pelos seringueiros, era majoritária. Contudo, a tentativa boliviana de controlá-los com a instalação de uma alfândega em Puerto Alonso que, diga-se de passagem, causou enormes prejuízos à receita do estado do Amazonas, originou movimentos separatistas por parte dos brasileiros. Em 14 de julho de 1899, Luis Galvez contou com o apoio militar e logístico dos comerciantes locais e do governo do Amazonas. Assim, ele declarou a independência do Acre, mas o Brasil não o reconheceu, pois temia que isso justificasse uma intervenção dos Estados Unidos que, à época, já era percebido como um ator hegemônico pelas tendências imperialistas de sua Big Stick Policy ${ }^{82}$. A contraofensiva da Bolívia veio, em dezembro de 1900, quando o seu exército ocupou a área e pôs fim à breve república. No ano seguinte, a Bolívia arrendou parte da região a uma empresa estrangeira, a Bolivian Syndicate. A companhia tinha como um dos seus sócios W. E. Roosevelt, primo de Theodore Roosevelt, vice-presidente dos Estados

\footnotetext{
${ }^{79}$ Ibidem, p. 95.

${ }^{80}$ MONIZ BANDEIRA, Luiz Alberto. Brasil, Argentina e Estados Unidos: conflito e integração na América do Sul. (Da Tríplice Aliança ao Mercosul) 3. ed. Rio de Janeiro: Civilização Brasileira, 2010, p. 76.

${ }^{81}$ COSTA, Mariete Pinheiro. O Parlamento e o Soldado da Borracha no Limiar da II Guerra Mundial. Monografia apresentada ao Curso de Especialização em Instituições e Processos Políticos do Legislativo - Câmara dos Deputados, Centro de Formação, Treinamento e Aperfeiçoamento. Brasília, 2007, p. 21-2.

${ }^{82}$ MONIZ BANDEIRA, Luiz Alberto. Op. cit., 2010, p. 76-8.
} 
Unidos. O modelo de negócio dava aos estrangeiros plenos poderes sobre o território arrendado pelo prazo de $30 \operatorname{anos}^{83}$.

A notícia de que essa companhia estrangeira havia negociado com o governo boliviano o arrendamento da região incendiou ainda mais a luta no Acre. Em 6 de agosto de 1902, surge um novo levante armado formado por seringueiros e liderado por Plácido de Castro, com respaldo dos proprietários de seringais e do governo do Amazonas $^{84}$. A revolução decretou o Acre território brasileiro, em contrapartida, o general José Manuel Pando, presidente da Bolívia, organizou novamente uma contraofensiva militar, e o rumor de que as forças armadas bolivianas iriam ocupar o território preocupou o governo brasileiro. Nesse contexto, em que a questão do Bolivian Syndicate atingia o seu clímax, José Maria da Silva Paranhos, o Barão do Rio Branco, assumiu a pasta do Ministério das Relações Exteriores, em 3 de dezembro de 1902. Ele negociou diplomaticamente um acordo com o país andino. Em 18 de novembro de 1903, Brasil e Bolívia celebraram o Tratado de Petrópolis e o Acre foi anexado ao Estado brasileiro, que comprou a região por 2 milhões de libras esterlinas, comprometendo-se, ainda, a construir a ferrovia Madeira-Mamoré e a indenizar a companhia estrangeira com 110 mil libras esterlinas ${ }^{85}$. Para Meira Mattos, coube à “excepcional visão de estadista do Barão do Rio Branco encontrar a solução” que atendeu tanto o Estado boliviano quanto a Bolivian Syndicate ${ }^{86}$. Contudo, ainda havia o Peru que tinha interesse na região.

Conforme observa Moniz Bandeira:

O Peru, que havia menos de três décadas perdera para o Chile, na Guerra do Pacífico (1879-1883), as províncias de Tarapacá, Tacna e Arica, não se conformara com a redução do seu território e, a revindicar outrossim aquela região da Amazônia, pretendera participar das negociações com a Bolívia, a fim de que houvesse uma solução tríplice ${ }^{87}$.

Para resolver diplomaticamente a questão com esse país, o governo brasileiro cedeu uma área triangular considerável, formada pelos rios Curanja, Santa Rosa e Purus $^{88}$. Em 1904, foi criado o Território Federal do Acre e, em 1962, foi elevado a estado. Para a geógrafa brasileira Therezinha de Castro, "o recuo no Prata seria

\footnotetext{
${ }^{83}$ Ibidem, p. 78.

${ }^{84}$ Ibidem, p. 80.

${ }^{85}$ Ibidem, p. 85-6.

${ }^{86}$ MATTOS, Carlos de Meira. Uma Geopolítica Pan-Amazônica. Rio de Janeiro: Bibliex, 1980, p. 59.

${ }^{87}$ MONIZ BANDEIRA, Luiz Alberto. Op. cit., 2010, p. 87.

${ }^{88}$ Ibidem, p. 91.
} 
geopoliticamente compensado com o Acre - avanço na Amazônia"89. O Barão do Rio Branco obteve para o Brasil 440 mil km² de área por via diplomática (30 mil referentes à disputa da região de Missões com a Argentina, 260 mil relativos ao Amapá e 150 mil do Acre $)^{90}$. Pelo seu destacado desempenho na consolidação das nossas fronteiras, sempre buscando soluções pacíficas para os conflitos com os vizinhos do Brasil, o Barão do Rio Branco é considerado o patrono da diplomacia brasileira e também um dos pioneiros da geopolítica do país, ao lado de Alexandre de Gusmão e José Bonifácio.

Por fim, cabe destacar também outro eminente personagem da história brasileira, José Bonifácio de Andrada e Silva, principal ideólogo da independência do Brasil que conseguiu promover a emancipação do país em 7 de setembro de 1822, mantendo a monarquia como forma de governo para justamente assegurar a unidade territorial do país. O triunfo do projeto conservador de José Bonifácio foi resultado de uma geopolítica de longo prazo que preferiu conservar a integridade territorial da América Portuguesa em torno apenas do Brasil. Para isso, naquele momento, foi condição sine qua non manter a escravidão como elemento de coesão. Tanto foi assim, que quando a Lei Áurea foi publicada, em 1888, abolindo a escravidão, tal medida desestabilizou politicamente a monarquia, que perdeu o apoio dos latifundiários escravocratas e foi substituída pelo sistema republicano, em 15 de novembro de 1889, com a proclamação da República. Por outro lado, na vizinhança hispano-americana, o projeto liberal de Simon Bolívar aboliu a escravidão e conquistou a soberania das novas repúblicas, mas não foi capaz de manter a unidade territorial da América Espanhola ${ }^{91}$ como no caso brasileiro.

O contraste entre a unidade geopolítica brasileira e a fragmentação hispanoamericana foi resultado do projeto conservador de José Bonifácio, que não desafiou a Ordem de Viena, que previa, desde 1815, a restauração das monarquias absolutistas europeias. Por essa razão, o Brasil, durante todo o período imperial, de 1822 a 1889, não era tido como uma ameaça pelas grandes potências centrais, pelo contrário, o país já nasce com o reconhecimento internacional. Ao passo que as repúblicas hispanoamericanas eram vistas como outsiders ${ }^{92}$ por parte da Pentarquia (Inglaterra, França, Prússia, Rússia e Áustria).

\footnotetext{
${ }^{89}$ CASTRO, Terezinha de. Op. cit., 1981, p. 28.

${ }^{90}$ MARTIN, André Robero. Op. cit., 1992, p. 83-4.

${ }^{91}$ CASTRO, Therezinha de. José Bonifácio e a unidade nacional. Rio de Janeiro: Bibliex, 1984, p. 23.

${ }^{92}$ Becker, Howard Saul. Outsiders: estudos de sociologia do desvio. Rio de Janeiro: Zahar. 2008, p. 15.
} 
Não é por acaso que José Bonifácio foi o principal ideólogo da independência do Brasil sob a regência de D. Pedro I. Ele Fez isso porque o príncipe era membro de uma dinastia europeia. Consequentemente, esse fator permitiu duas vantagens ao Brasil: a) no plano internacional, Bonifácio sabia que a monarquia no Brasil estava de acordo com a Ordem de Viena ${ }^{93}$. Portanto, o país teria maiores chances de obter o reconhecimento internacional de sua independência, evitando, assim, ameaças externas a sua soberania; b) no plano doméstico, a monarquia livrar-nos-ia também da fragmentação territorial ocorrida na América Espanhola ${ }^{94}$.

Formado em Filosofia e Direito pela Universidade de Coimbra, Bonifácio teve contato com os textos dos pensadores revolucionários franceses. Destaque para a obra $O$ contrato social, de Jean-Jaques Rousseau, publicada em 1762. Nela, o autor aconselha que a monarquia é a melhor forma de governo para os Estados grandes geograficamente:

Em suas palavras:

\begin{abstract}
Vimos pelas relações gerais que a monarquia só é conveniente aos grandes Estados e tornamos a descobrir isso ao examiná-la nela mesma. Quanto mais numerosa for a administração pública, tanto mais a relação do Príncipe com os súditos diminui e aproxima-se da igualdade, e essa relação é uma ou a própria igualdade na democracia. A mesma relação aumenta, à medida que o Governo se contrai, e atinge seu máximo quando o Governo está nas mãos de um só ${ }^{95}$.
\end{abstract}

Diante de uma conjuntura geopolítica marcada pela ameaça de intervenções europeias e também, de certo modo, dos Estados Unidos, devido a sua política unilateral baseada na Doutrina Monroe, Simon Bolívar escreveu a Carta da Jamaica, em 1815 e, posteriormente, convocou o Congresso do Panamá, em 1826, com o objetivo de organizar uma confederação hispano-americana para defender a soberania das novas repúblicas. Mas o Brasil não participou do Congresso do Panamá por dois motivos: primeiro porque era uma monarquia escravagista, em oposição ao projeto republicano e abolicionista de Bolívar; em segundo lugar, o Brasil já tinha o reconhecimento internacional de sua independência e a sua soberania não estava ameaçada pelas nações da Santa Aliança, pelo contrário, nosso país era bem visto pelas grandes potências mundiais, pelo fato de ser governado por uma dinastia europeia. Aliás, muito daquele

\footnotetext{
${ }^{93}$ CASTRO, Therezinha de. Op. cit., 1984, p. 88.

94 Ibidem, p. 53.

${ }^{95}$ ROUSSEAU, Jean-Jaques. O contrato social. Porto Alegre: L\&PM, 2009, p. 86.
} 
mito que se ouve falar de que o brasileiro não é de briga, mas sim é um povo pacifista, tem a ver com a inserção internacional do Brasil naquela época. Portanto, por ser o principal ideólogo da independência do Brasil, garantir a unidade territorial da América portuguesa em torno exclusivamente do nosso país e promover a inserção internacional do Estado brasileiro de forma soberana, José Bonifácio é considerado não só o patriarca da independência, mas também é reconhecido como um dos "precursores da geopolítica brasileira" 96 .

\subsubsection{Teoria geopolítica pré-esguiana: Mario Travassos}

O capitão Mario Travassos (1891-1973), oficial do Exército brasileiro, participou da Força Expedicionária Brasileira (FEB), que lutou na Itália durante a Segunda Guerra Mundial, foi o primeiro comandante da Academia Militar das Agulhas Negras (AMAN) e membro da comissão que escolheu o local da nova capital federal, encerrando a sua carreira como oficial general. Embora o estudo da geopolítica tenha sido introduzido no Brasil na década de 1920, quando Elysio de Carvalho ${ }^{97}$, Everardo Backheuser $^{98}$ e Carlos Delgado de Carvalho ${ }^{99}$ publicam seus trabalhos sobre o tema, foi apenas na década seguinte que se afirmaria no país uma Escola Geopolítica Brasileira, na figura de Mario Travassos que se destacará, sem dúvida, como um geopolítico notável do ponto de vista teórico-metodológico. Ele influenciou os militares como os generais Golbery e Meira Mattos, que fundamentaram suas análises geopolíticas sobre a América do Sul à luz do modelo travassiano ${ }^{100}$.

O seu livro Aspectos Geográficos Sul-Americanos, publicado em 1931, teve grande repercussão entre os militares e também na sociedade civil, cujo interesse resultou em uma segunda edição, publicada em 1935, e por sugestão dos editores, com um novo título Projeção Continental do Brasil ${ }^{101}$. De acordo com Wanderley Messias,

\footnotetext{
${ }^{96}$ MATTOS, Carlos de Meira. Op. cit., 2011, p. 178.

97 Elysio de Carvalho escreveu os livros, Brasil Potência Mundial - Inquérito sobre a Indústria Siderúrgica no Brasil, em 1919; O fator geográfico na política brasileira, em 1921.

${ }^{98}$ Dentre as principais contribuições de Everardo Backheuser para o estudo da Geopolítica salienta-se: $A$ Estrutura Política do Brasil. Notas Prévias, em 1926; Problemas do Brasil - Estrutura geopolítica, em 1933; A Geopolítica Geral e do Brasil, em 1955.

${ }^{99}$ Nas obras de Delgado de Carvalho, destaca-se: Introdução à Geopolítica, publicado em 1929.

100 ALBUQUERQUE, Edu Silvestre de. 80 anos da obra projeção continental do Brasil, de Mário Travassos. Revista do Departamento de Geografia, São Paulo, v. 29, p. 61, jun., 2015.

${ }^{101}$ VLACH, Vânia Rubia Farias. Estudo preliminar acerca dos geopolíticos militares brasileiros. Revista Terra Brasilis. São Paulo,v. 4, n. 5, 2003, p. 1.
} 
o mérito de Travassos consiste em fazer uma análise do Brasil à luz da geopolítica, servindo de bússola para orientar a política do Estado brasileiro na América do Sul:

A análise geopolítica de Travassos é não apenas pioneira como original nesse tipo de discurso no país. Ao contrário dos demais do período, ela parte de uma minuciosa descrição das condições geográficas primárias do continente e do território brasileiro ${ }^{102}$.

As principais ideias de Mario Travassos podem ser resumidas nos dois antagonismos geográficos na América do Sul: oceano Atlântico versus Pacífico, divididos pela Cordilheira dos Andes; e o segundo antagonismo consiste entre as bacias Platina versus Amazônica, que culminam "no planalto boliviano, que muito bem se pode considerar o centro geográfico" 103 .

${ }^{102}$ COSTA, Wanderley Messias da. Op. cit., 2013, p. 198.

${ }^{103}$ TRAVASSOS, Mario. Projeção Continental do Brasil. 3. ed. São Paulo: Editora Nacional, 1938, p. 3, 9, 141. 
Mapa 4: Dois antagonismos geográficos na América do Sul

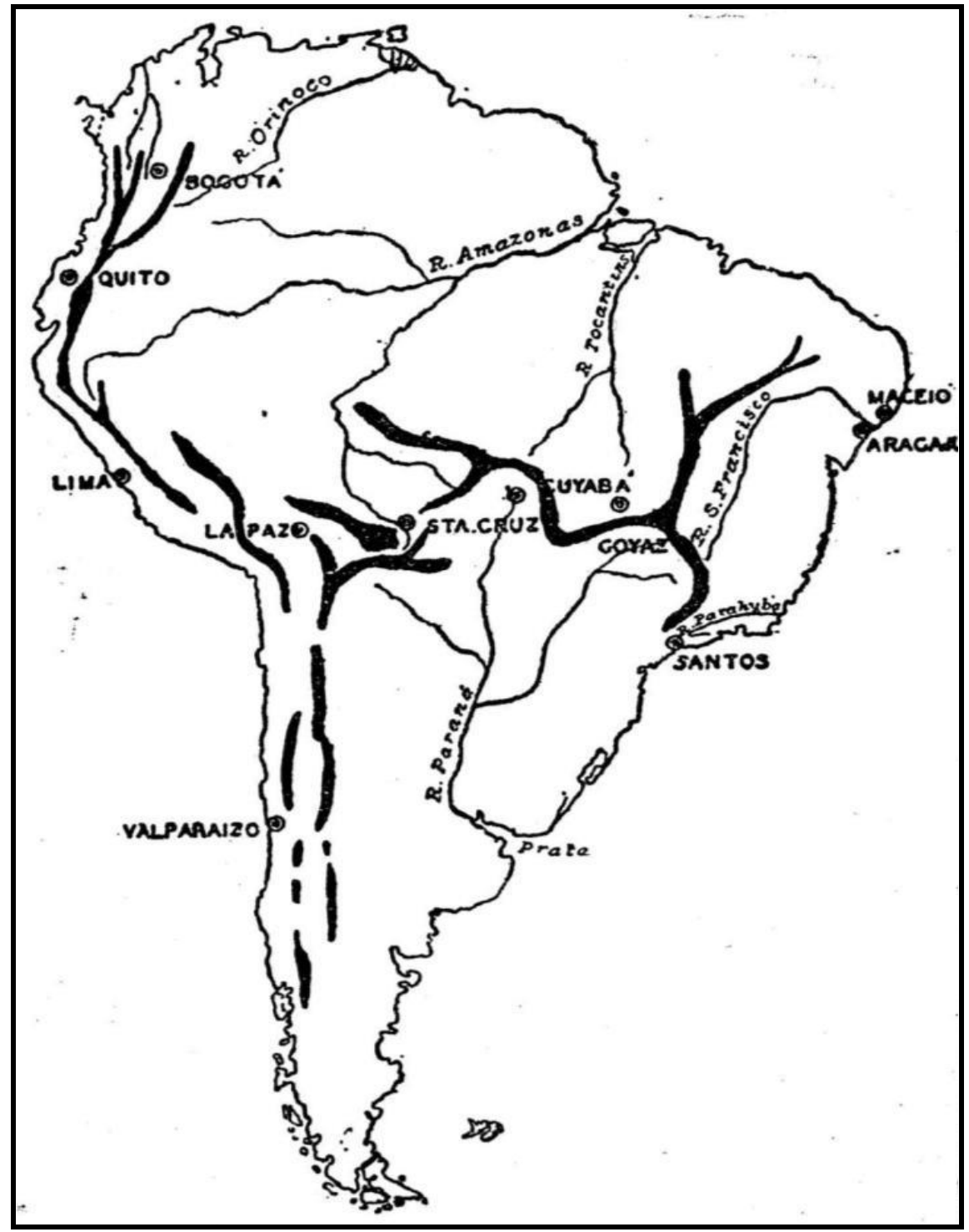

Fonte: TRAVASSOS, Mario. Projeção Continental do Brasil. 3. ed. São Paulo: Editora Nacional, 1938, p. 7.

Segundo Leonel Itaussu, embora esses antagonismos sejam de natureza geográfica, seus resultados influenciam na balança de poder regional:

É no coração do altiplano que Travassos localiza o triângulo estratégico formado por Cochabamba-Santa Cruz-Sucre, ou seja, a região que constituía o "verdadeiro signo da riqueza boliviana". O controle desse triângulo estratégico era vital, segundo a concepção geopolítica de Travassos, para a resolução do antagonismo Amazonas-Prata, quer a favor do Brasil, quer a favor da Argentina ${ }^{104}$.

104 MELLO, Leonel Itaussu Almeida. A Geopolítica do Brasil e a Bacia do Prata. Dissertação de Mestrado em Ciência Política apresentada ao Departamento de Ciências Sociais da Pontifícia Universidade Católica de São Paulo, PUC-SP. São Paulo, 1987, p. 81-2. 
A preocupação de Travassos é, sem dúvida, o triângulo econômico Cochabamba-Santa Cruz de la Sierra-Sucre que, segundo ele, está dominado por Buenos Aires, razão pela qual chega a chamar o país vizinho de imperialista ${ }^{105}$. A hegemonia platina no heartland sul-americano só foi possível devido à criação de uma rede ferroviária interoceânica pela Argentina interligando-a com o oceano Pacífico:

O esquema que materializa o esforço ferroviário platino dá, por si mesmo, ideia do vulto econômico e político do sistema de comunicações do Prata. Não só deixa sentir, em toda sua expressão, o caráter concêntrico do sistema, como indica, desde logo, o grau de sua repercussão sobre as redes circunvizinhas $^{106}$.

A implantação de um meio técnico no território argentino surgiu na segunda metade do século XIX, com a criação da primeira estrada de ferro no país, em 1857. Capitais públicas nacionais e britânicas são responsáveis pela expansão da rede ferroviária, que passa de $732 \mathrm{~km}$, em 1870, para 12 mil km em 1890, e chega a 34.900 km, em $1930^{107}$. Segundo José Luís Fiori, a utilização dessa nova técnica no território permitiu que a Argentina integrasse o seu mercado nacional, antes do fim do século $\mathrm{XIX}^{108}$, enquanto que o Brasil só começou a pensar em uma rede de transporte integrada no governo Vargas, com o Plano Geral de Viação Nacional. Milton Santos teorizou sobre a implantação de um meio técnico. Para ele, "quando um determinado ator não tem as condições para mobilizar as técnicas consideradas mais avançadas, torna-se um ator de menor importância"109.

A rede ferroviária da Argentina possibilitou a integração do seu mercado interno com o de Buenos Aires, transformando a dinâmica anterior, na qual a província de Mendoza, na região de Cuyo, vinculava-se principalmente com o Chile; a cidade La Quiaca, localizada na província de Jujuy, no Noroeste, estava ligada à Bolívia; e Posadas, capital da província de Misiones, situada no Nordeste da Argentina, conectada ao Paraguai" ${ }^{110}$. Daí decorre, de certa forma, o caráter concêntrico da rede ferroviária de Buenos Aires, que visava recompor o seu comércio com essas três regiões produtivas -

\footnotetext{
105 TRAVASSOS, Mario. Op. cit., 1938, p. 25, 200.

106 Ibidem, p. 16.

${ }^{107}$ SILVEIRA, Maria Laura. Argentina: território e globalização. São Paulo: Brasiliense. 2003, p. 21-22.

108 FIORI, José Luís. O protótipo argentino. Carta Maior, 31 out. 2012. Disponível em: <http://www.cartamaior.com.br/?/Coluna/O-prototipo-argentino/26851>. Acesso em: 12 mar. 2017.

${ }^{109}$ SANTOS, Milton. Por uma outra globalização: do pensamento único à consciência universal. 24 ed. Rio de Janeiro: Record, 2015, p. 25.

${ }^{110}$ SILVEIRA, Maria Laura. Op. cit., 2003, p. 22.
} 
Cuyo, Noroeste e Nordeste - e se projetar geopoliticamente no seu entorno regional geoestratégico, invertendo a lógica antecedente.

Contudo, Travassos identificou a geopolítica de Buenos Aires como uma ameaça aos interesses do Brasil, pois a sua rede ferroviária extrapolava o seu mercado interno, integrando-se também com as três cidades dos países fronteiriços: Assunção, Santiago, e La Paz, como se pode comprovar no mapa 5 abaixo.

Mapa 5: Centralidade do sistema ferroviário argentino

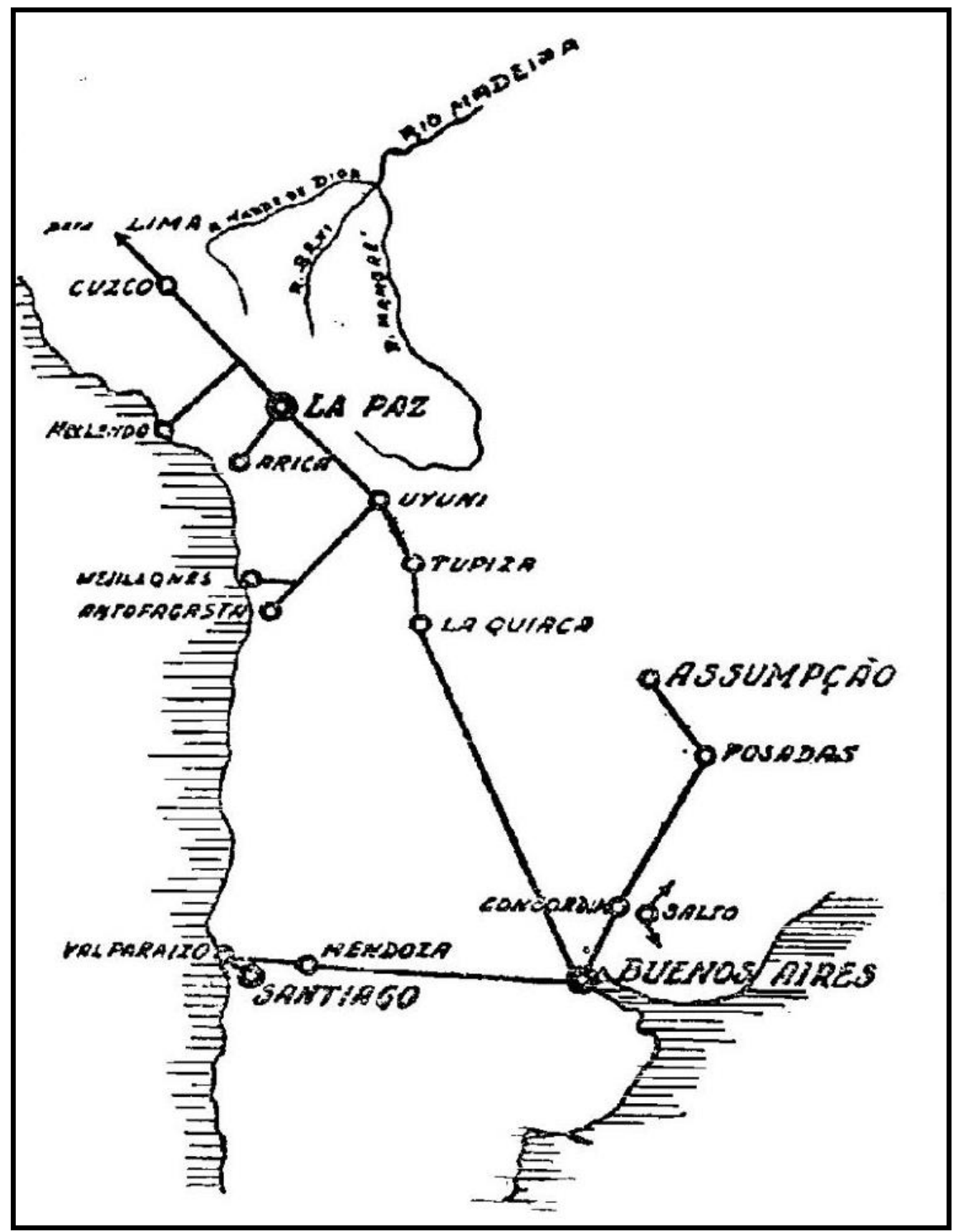

Fonte: TRAVASSOS, Mario. Op. cit., 1938, p. 17.

O mapa 5 apresenta a projeção geopolítica da rede ferroviária Argentina. Segundo Eli Alves Penha, “a ligação ferroviária entre Buenos Aires e La Paz garantiu à 
Argentina a extensão da sua influência sobre a Bolívia, considerada zona de transição entre os dois antagonismos" 111 . É com essa última articulação terrestre Buenos Aires-La Paz que Travassos está mais preocupado, pelo fato de a Argentina, ao mesmo tempo em que estende a sua zona de influência no Pacífico, neutraliza a influência brasileira sobre o heartland sul-americano:

\begin{abstract}
Quanto à repercussão do sistema sobre as redes circunvizinhas, esse é aspecto dos que merecem atenção especial. Se nas ligações Buenos Aires-Santiago e Buenos Aires-Asunción essa repercussão não ultrapassa os limites de suas naturais consequências, da ligação Buenos Aires-La Paz advêm reflexos capazes de repercussão até mesmo sobre a economia continental ${ }^{112}$.

[...] dentre os aspectos mais importantes do esforço ferroviário platino, é notável o vulto econômico e político da ligação Buenos Aires-La Paz. Em primeiro lugar, essa ligação, embora indiretamente, multiplica os contatos da vertente atlântica com o Pacífico [...]. Em seguida está o papel que seus trilhos representam, frente às cabeças dos vales da bacia do Madeira, como barreira econômica, verdadeira calha, na antiplanície, em favor do Prata $[\ldots]^{113}$.
\end{abstract}

Além da penetração de Buenos Aires no altiplano boliviano, a sua rede ferroviária permitia "a multiplicação dos contatos com o oceano Pacífico" através da ligação com quatro importantes portos de Valparaíso, Antofagasta, Mejillones e Arica, no Chile e, Mollendo, no Peru ${ }^{114}$. Travassos lembra que a busca pelo acesso a mares e oceanos não era uma excepcionalidade da Argentina, mas que isso é uma "tendência dos Estados de possuírem várias saídas para o mar, se possível para mares diferentes"115. Ele cita o caso de Brandemburgo - núcleo geohistórico da Alemanha - que mesmo possuindo uma saída para o Báltico, aspirava ter também acesso a outros mares e oceanos. Assim, aquele pequeno Estado se transformou na Prússia com acesso ao mar do Norte e, em seguida, no Estado Alemão, em 1870. Sua aliança com países vizinhos lhe permitiu chegar ao mar Mediterrâneo, conclui Travassos, "sem embargo, o fundamento de todos é a multiplicação das saídas para o mar, no caso, para mares diferentes"116.

\footnotetext{
${ }^{111}$ PENHA, Eli Alves. A criação do IBGE no contexto da criação do Estado Novo. Rio de Janeiro: IBGE, Centro de Documentação e Disseminação de Informações, 1993, p. 33.

112 TRAVASSOS, Mário. Op. cit., 1938, p. 18-9.

${ }^{113}$ Ibidem, p. 23-4.

${ }^{114}$ Ibidem, p. 19.

${ }^{115}$ Ibidem, p. IX.

${ }^{116}$ Ibidem, p. XII.
} 
Contrapondo ao projeto argentino na região, Travassos formulou uma geoestratégia que consistia em transferir a centralidade de Cochabamba, no triângulo econômico boliviano, para Santa Cruz, em razão de a primeira cidade estar na zona de influência Platina, ao sul, e a segunda estar ligada à atração da Amazônia pelos seus afluentes ao norte. O mapa 6, abaixo, elucida magnificamente seu ponto de vista:

Mapa 6: Potencialidade amazônica no Altiplano boliviano

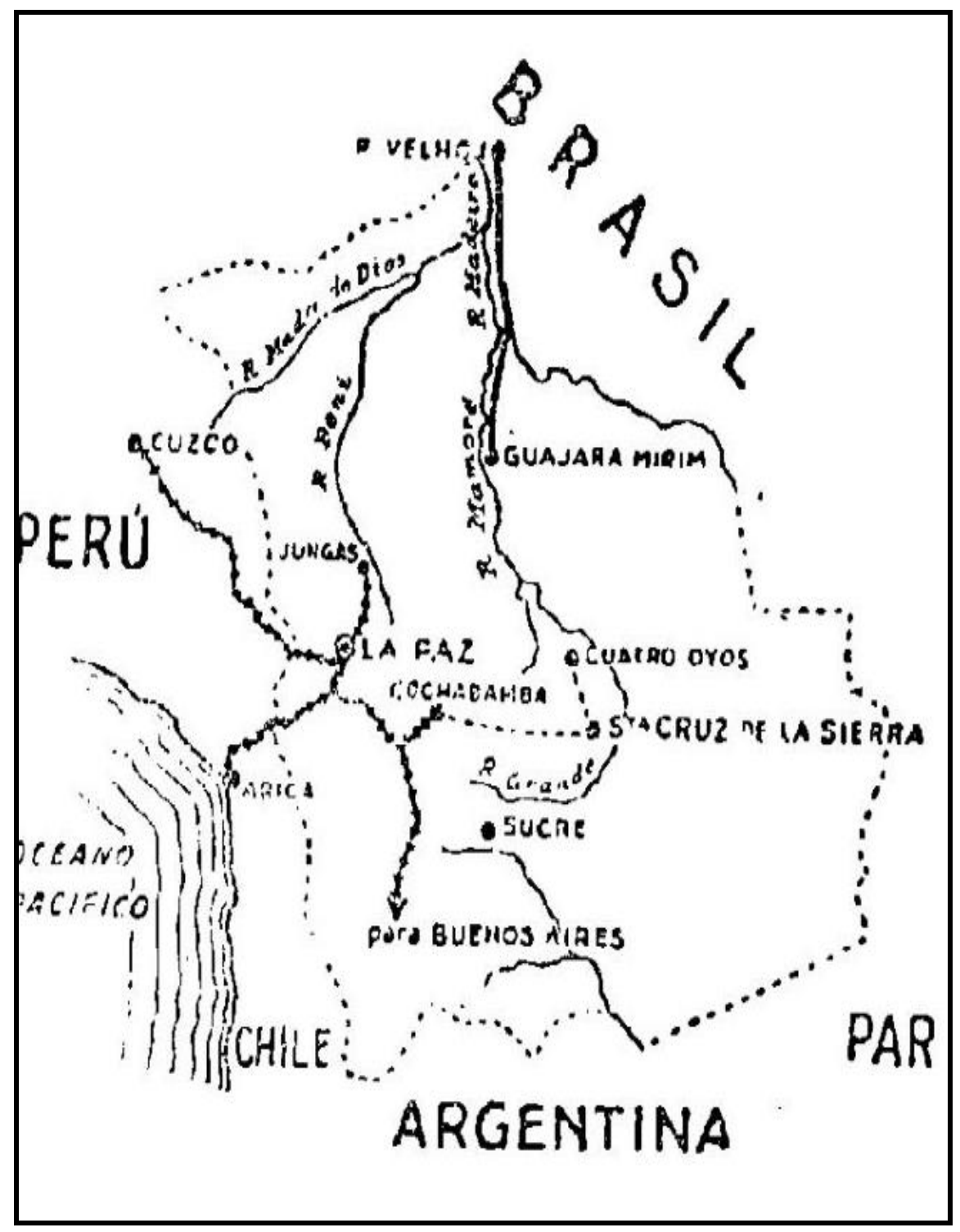

Fonte: TRAVASSOS, Mario. Op. cit., 1938, p. 26.

O mapa 6 demostra que a transferência do eixo de gravitação de Cochabamba para Santa Cruz permitiria ao Brasil o controle do triângulo econômico, o que 
neutralizaria o sistema ferroviário argentino e a bacia do Prata, deixando o altiplano boliviano sob a influência da bacia Amazônica ${ }^{117}$.

Sobre isso, escreve Travassos:

Do exposto resulta que se trata apenas de deslocar o centro de atração da região de Cochabamba para Santa Cruz, inclusive, porque a atração exercida por Cochabamba é por assim dizer artificial, produto das facilidades de comunicações de que tem desfrutado, ao passo que Santa Cruz representa realmente o verdadeiro centro de gravidade da economia do planalto ${ }^{118}$.

Daí decorre o conceito de "corredores de exportação" com vistas a atrair para sua órbita a Bolívia, que estava, até então, na zona de influência de Buenos Aires. Ele considera que o Brasil deve desenvolver uma política de transportes capaz de neutralizar a Argentina e retomar a liderança da região ${ }^{119}$.

Para tanto, apresenta uma geoestratégia baseada em dois sistemas de comunicações: a primeira transverval e a segunda longitudinal. O primeiro sistema seria estruturado em duas etapas: os corredores de exportação e os passos e nudos. A primeira etapa destacava a passagem brasileira norte-leste. No corredor norte, propõe utilizar a atração dos rios Madeira-Mamoré para a implantação de um transporte fluvial desde Santa Cruz de la Sierra-Cuatro Oyos-Guajará Mirim até o rio Amazonas ${ }^{120}$. Já o corredor leste ligará as cidades Santa Cruz de la Sierra-Porto Suarez-Corumbá até o porto de Santos ${ }^{121}$, conforme pode-se constatar no mapa 7.

\footnotetext{
${ }^{117}$ MELLO, Leonel Itaussu Almeida. Op. cit., 1987, p. 84.

118 TRAVASSOS, Mário. Op. cit., 1938, p. 28.

${ }^{119}$ Ibidem, p. 29.

${ }^{120}$ Ibidem, p. 64, 66.

${ }^{121}$ Ibidem, p. 65.
} 
Mapa 7: O heartland sul-americano e seus corredores de exportação

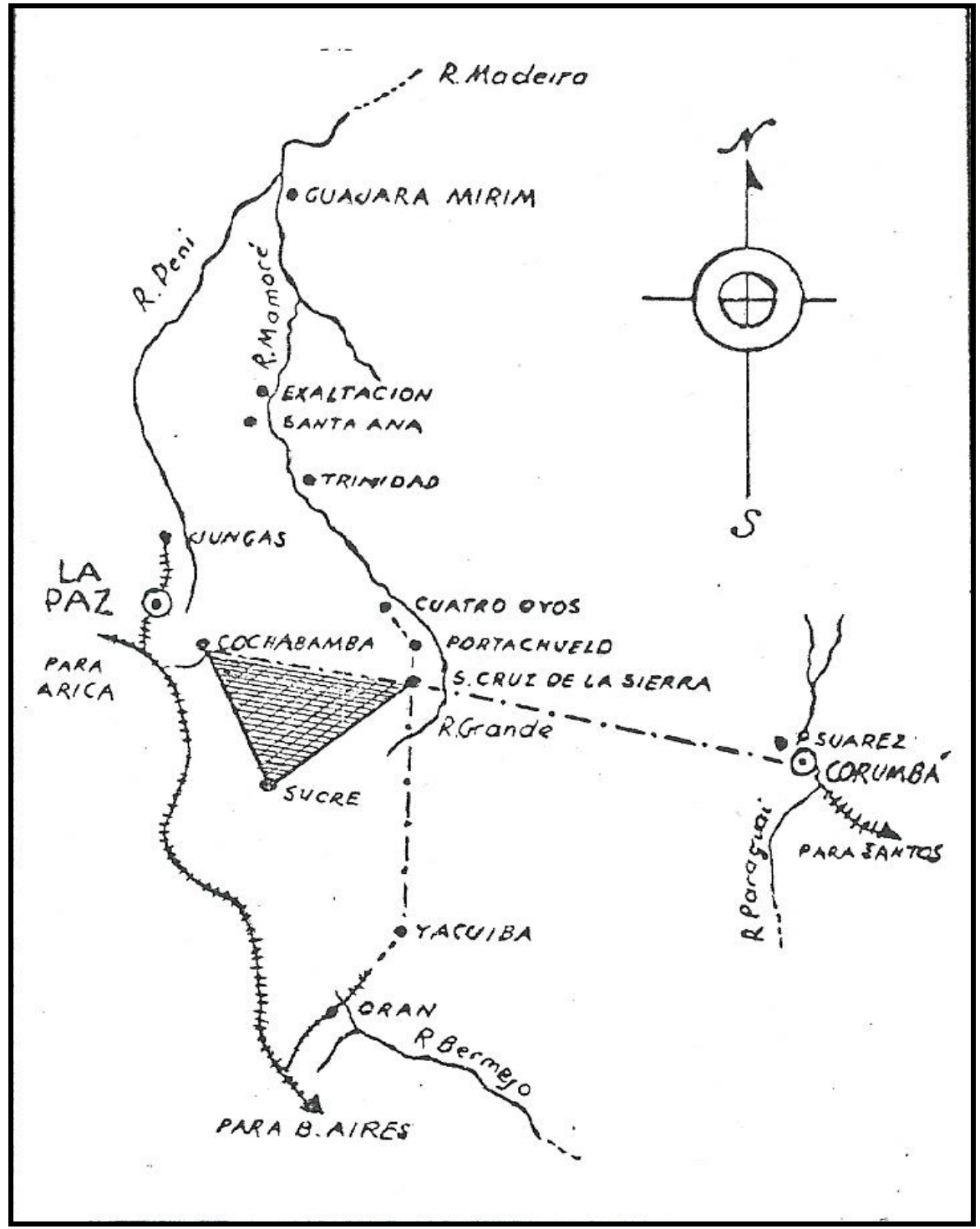

Fonte: Adaptado de TRAVASSOS, Mario. Projeção Continental do Brasil. In: MIYAMOTO, Shiguenoli. O Pensamento Geopolítico Brasileiro (1920-1980). Dissertação de Mestrado apresentada ao Departamento de Ciências Sociais (área de Ciência Política) da Faculdade de Filosofia, Letras e Ciências Humanas da Universidade de São Paulo. São Paulo, 1981, p. 67.

Uma vez garantido o controle do heartland sul-americano pelo Estado brasileiro, através dos corredores de exportação norte-leste, a próxima etapa do Brasil seria ampliar a sua zona de influência em direção ao oeste até chegar ao Pacífico, tornando-se um país bioceânico. Para isso, seria necessário transpor a Cordilheira dos Andes através das regiões pasos e nudos ali existentes ${ }^{122}$, conforme mostra o mapa 8.

122 Segundo Travassos, há “duas categorias de abiertas: uma, os pasos, que são passagens naturais permitidas por descontinuidades na linha da cordilheira; outra, os nudos, que são planaltos formados em torno de um pico e que também permitem a transposição do abstáculo natural. Ainda segundo ele, entre outros, os nudos de Pasco e de Cusco, ambos no território peruano, interessariam ao Brasil pela sua 
Mapa 8: A cordilheira dos Andes e as regiões Pasos e Nudos

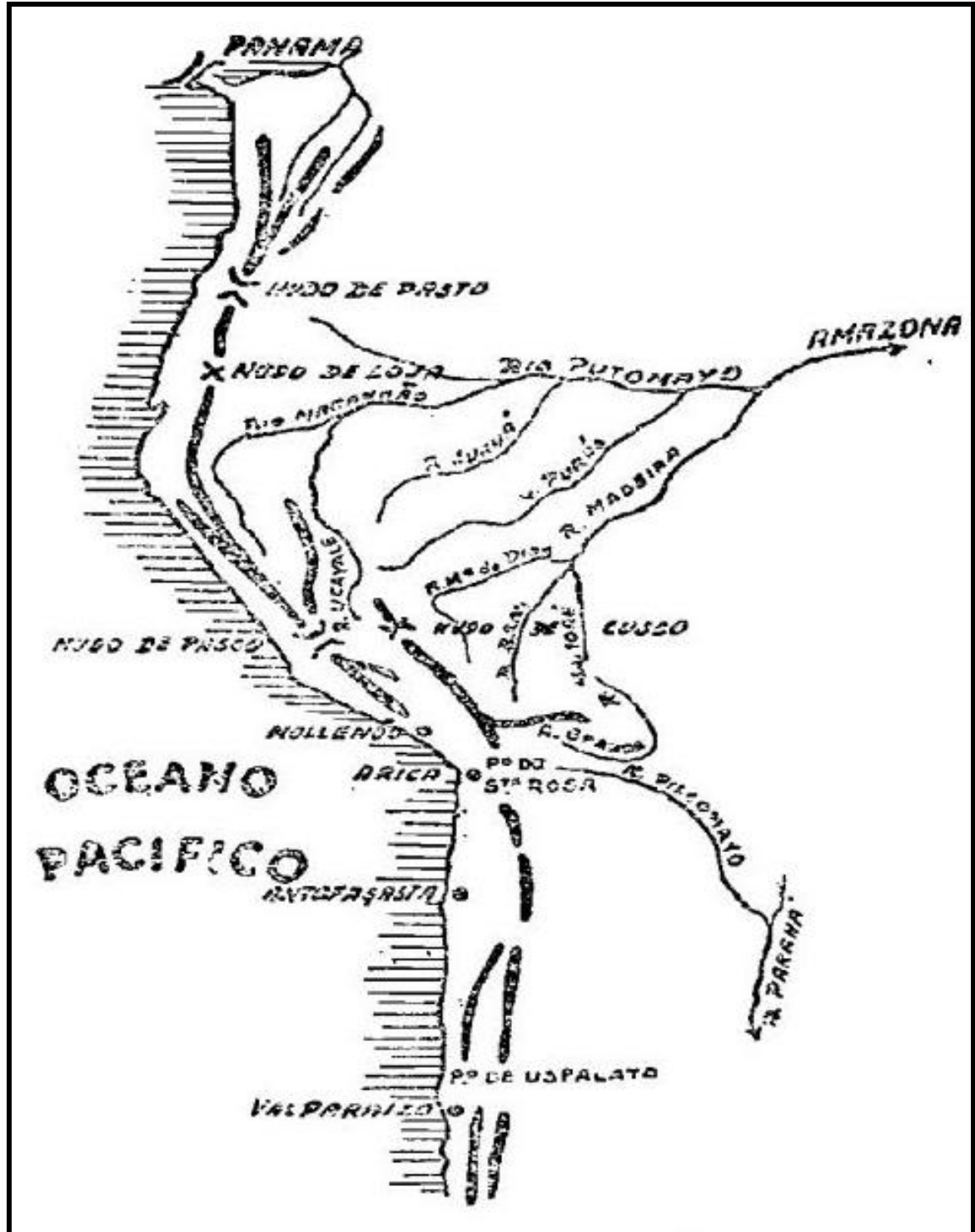

Fonte: TRAVASSOS, Mario. Op. cit., 1938, p. 31.

Se no mapa anterior (mapa 7), Travassos demonstrou sua genialidade em formular uma geoestratégia capaz de alterar a balança de poder no heartland sulamericano, através dos corredores de exportação norte-leste, neutralizando a atração do Prata, nesse (mapa 8), ele apresenta a capacidade de projeção geopolítica do Brasil para o Pacífico via pasos e nudos. Em suas próprias palavras:

proximidade com o curso superior do rio Madeira, este num dos pontos mais ocidentais do território brasileiro" (VIEIRA, Friederick Brum. Modelo travassiano: a geopolítica que guia o Brasil na ditadura e na democracia. Rio de Janeiro: Milênio, 2008, p. 75). 
Quando as possibilidades carreadoras da Amazônia se verificarem a pleno rendimento e conjugadamente com as abertas andinas, excluindo apenas o Paso de Uspalata, as bocas do Amazonas despejarão no Atlântico grande parte da riqueza do centro e da vertente ocidental do continente ${ }^{123}$.

A projeção geopolítica do Brasil no Pacífico traria três vantagens ao país: 1) o Brasil se tornaria um país bioceânico; 2) a comunicação entre a vertente ocidental e oriental da América do Sul seria um estímulo para a intensificação do comércio intraregional; 3) o Brasil canalizaria "para o Atlântico grande parte da produção dos países andinos" $" 124$.

Já no segundo sistema de comunicações, denominado longitudinal, Travassos destaca a importância das "regiões naturais brasileiras" na sua geoestratégia, como se pode ver no mapa 9.

\section{Mapa 9: Regionalização do Brasil segundo Mario Travassos}

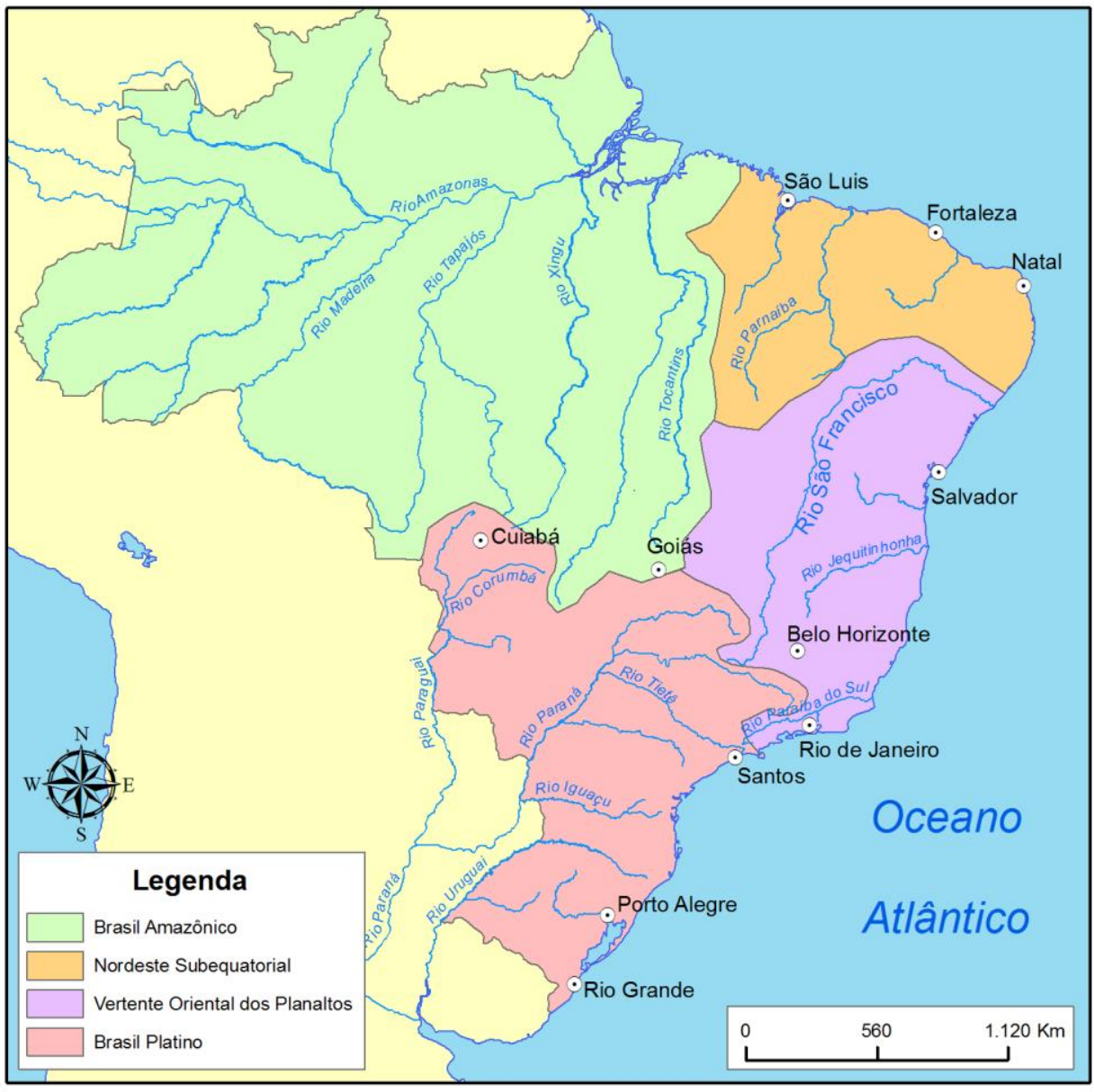

Fonte: TRAVASSOS, Mario. Op. cit., 1938, p. 89.

123 TRAVASSOS, Mário. Op. cit., 1938, p. 39-40.

${ }^{124}$ MELLO, Leonel Itaussu Almeida. Op. cit., 1987, p. 86. 
O mapa 9 apresenta uma regionalização do espaço brasileiro em quatro "regiões naturais": o Brasil Amazônico, o Nordeste Subequatorial, a Vertente Oriental dos Planaltos e o Brasil Platino. A seguir, Travassos descreve as principais características dessas quatro regiões do Brasil:

O Brasil Amazônico comportando a região serrana (maciço granítico das
Guianas), a depressão amazônica (calhas do Amazonas e seus afluentes) e a
Hiléia (região das matas); o Nordeste Subequatorial abrangendo o Golfo
Maranhense (sorte de transição da Amazônia), a bacia do Parnaíba, as Serras
e Chapadas da Vertente Norte-Oriental (regiões semi-áridas), o litoral, a mata
e o agreste de Pernambuco (balizada pelo Cabo de S. Roque, foz do S.
Francisco e Serra da Borborema); a Vertente Oriental dos Planaltos
compreendendo o litoral baiano-espírito-santense (inclusive as bacias do
Paraguaçú, Jequitinhonha e Doce) e a região das chapadas (zona alta), o vale
do S. Francisco, o Sul Mineiro e o vale do Parába; o Brasil Platino
englobando a costa ou contra-vertente oceânica (entre o Atlântico e a Serra
do Mar), a Região Serrana (Serra do Mar e Geral), a região do Planalto
(alternação de campos e matas, região suporte dos afluentes orientais do
Paraná), a campanha rio-grandense e a baixada mato-grossense - em seu
conjunto, nada mais espontâneo que essas grandes divisões e respectivas
subdivisões ${ }^{125}$.

Ainda nessa linha, Travassos destaca o papel funcional de duas "regiões naturais brasileiras": o Nordeste Subequatorial e a Vertente Oriental dos Planaltos ${ }^{126}$. Elas estabelecem a integração do Brasil Amazônico e Platino através de uma articulação viária longitudinal, obedecendo à orientação das calhas de suas bacias hidrográficas ${ }^{127}$. Para ele, "o papel funcional dessas duas regiões é de ligar, homogeneizar, amarrar os dois brasis essenciais, do ponto de vista continental, o platino e o amazônico" ${ }^{128}$.

Com relação às outras duas "regiões naturais brasileiras": O Brasil Amazônico e o Platino, Travassos observou que, embora sejam os pontos mais extremos do país, ambos convergem para o pivot geográfico sul-americano. Diferentemente do Brasil Amazônico, que se liga naturalmente ao oceano Atlântico, pelo rio Amazonas, o Brasil Platino liga-se por meios artificiais ao mesmo oceano. O território brasileiro dispõe de portos com suficiente capacidade de atração na costa, estimulando os dois países mediterrâneos - Bolívia e Paraguai - que naturalmente querem romper com a dependência e vulnerabilidade provenientes de Buenos Aires ${ }^{129}$. Por isso mesmo, ele

\footnotetext{
125 TRAVASSOS, Mário. Op. cit., 1938, p. 88-90.

${ }^{126}$ Ibidem, p. 92-3.

${ }^{127}$ ALBUQUERQUE, Edu Silvestre de. Op. cit., 2015, p. 69.

128 TRAVASSOS, Mário. Op. cit., 1938, p. 93.

129 Ibidem, p. 91.
} 
pensou na criação de uma rede de transportes que integrasse os países vizinhos, em especial a Bolívia e o Paraguai à costa atlântica brasileira.

Desse modo, a cidade de Santa Cruz de la Sierra é geoestratégica, devido a sua posição (lage) permitir uma maior comunicação ferroviária e hidroviária com o Brasil, do que com a Argentina ${ }^{130}$. Corrobora essa ideia a própria distância dessa cidade em relação a Buenos Aires, que gastaria $3.285 \mathrm{~km}$, enquanto que pela via brasileira seria $2.576 \mathrm{~km}$, portanto, $709 \mathrm{~km}$ a menos ${ }^{131}$. O uso racional dessas "regiões naturais" asseguraria a liderança do Brasil na América do Sul.

Segundo o contra-almirante argentino Jorge Fraga, "perdida definitivamente a interferência sobre a bacia Platina, o Brasil busca modificar a sua atração geopolítica mediante ferrovias e rodovias desde Bolívia e Paraguai para seus portos de Paranaguá e Santos"132. Contudo, a própria Bolívia desmente essa ideia ao buscar, por si mesma, sair da zona de influência de Buenos Aires através da criação de uma estrada de ferro alternativa ao norte em direção à bacia Amazônica:

\begin{abstract}
A estrada la Paz-Yungas é precioso esforço, embora secundário, que os bolivianos fazem para escapar às malhas ferroviárias do Prata, levando pelo Bení, para as águas do Amazonas, a maior e melhor parte da riqueza da vertente nordeste do planalto. Resta montar o esforço principal, ou seja, completar o lanço magnífico que a Madeira-Mamoré representa, fazendo aproximar, de qualquer sorte, as pontas dos seus trilhos da região de Santa Cruz de la Sierra, mesmo dobrando a via fluvial. Essas são as grandes linhas do problema. Em presença delas se tem de reconhecer a espontaneidade viatória da Amazônia, nessa região, em contraste com o artificialismo da atração ferroviária platina. E essa razão é bastante para que se reconheçam as comunicações da Amazônia como capazes de contrabalançar a servidão atual do planalto boliviano às comunicações platinas ${ }^{133}$.
\end{abstract}

Por fim, a pluralidade e integração dos meios de transportes do país é uma condição sine qua non para a superação definitivamente da conjugação férreo-fluvial da Argentina:

A nosso ver essa é lição de primeira ordem. Quer parecer-nos que, ao invés de planos separados de comunicações marítimas, terrestres, fluviais, aéreas, etc., deveríamos ter um plano de conjunto, jogando com as possibilidades que

\footnotetext{
${ }^{130}$ VIEIRA, Friederick Brum. Op. cit., 2008, p. 75.

${ }^{131}$ TRAVASSOS, Mário. Op. cit., 1938, p. 65.

${ }^{132}$ FRAGA, Jorge Alberto. La Argentina y el Atlântico Sur: conflictos y objetivos. Buenos Aires: Editora Pleamar y Instituto de Publicaciones Navales del Centro Naval. 1983, p. 73.

133 TRAVASSOS, Mário. Op. cit., 1938, p. 28-9.
} 
nos oferecem todos os meios de transportes proporcionados pela indústria moderna $^{134}$.

Em função de o Estado brasileiro apresentar uma larga extensão territorial nortesul, e também uma grande distância no sentido leste-oeste, na porção setentrional, é necessário organizar uma matriz multimodal integrada (ferroviária, rodoviária, hidroviária, aérea), que ligue os diferentes pontos do território nacional, de modo a proporcionar um melhor deslocamento de pessoas e mercadorias. Apesar das potencialidades desses sistemas de transportes, se utilizados isoladamente, não serão capazes de resolver todos os nossos problemas ${ }^{135}$. Por essa razão, Travassos propõe a criação de uma rede multimodal brasileira:

Mas o que não se pode negar é que, dados os aspectos geográficos sulamericanos que vimos focalizando - como aspectos essenciais ou como signos de inquietação política - somente sob o domínio da pluralidade dos transportes poderá o Brasil exprimir toda a força de sua imensa projeção coordenadora no cenário da política e economia continental, tal como incontestavelmente lhe compete ${ }^{136}$.

Travassos explica também que a balança de poder na América do Sul é marcada pela "instabilidade geográfica". De acordo com Leonel Itaussu, os casos de “instabilidade geográfica" se caracterizam pela oscilação, entre Estados vizinhos, leiase, Brasil e Argentina, ou mesmo uma potência extra-regional em "determinados territórios"137. Segundo Travassos, "territórios assim, oscilantes, são verdadeiros focos de perturbações políticas, causas de dissensões ou, pelo menos, de preocupações sérias para que se evitem possíveis conflitos internacionais" "138. O autor cita três exemplos de instabilidade geográfica: a Bolívia, a Colômbia e o Uruguai.

No primeiro caso, a própria característica fisiográfica da Bolívia contribui para a sua instabilidade política. Sobre isso esclarece Leonel Itaussu:

A instabilidade da Bolívia tinha como fatores determinantes a sua condição
de país mediterrâneo, amputado em sua costa marítima pela Guerra do
Pacífico, com seu território ocidental vinculado à cordilheira dos Andes e sua
região oriental oscilando entre as bacias amazônica e platina. Essa oscilação
pendular se processava, de fato, entre os polos de atração representados pelo
Brasil e a Argentina. Este último país era, naquele momento, o grande
beneficiário da instabilidade da Bolívia, uma vez que esta se encontrava na

\footnotetext{
134 Ibidem, p. 115.

${ }^{135}$ Ibidem, p. 115-7.

${ }^{136}$ Ibidem, p. 117.

${ }^{137}$ MELLO, Leonel Itaussu Almeida. Op. cit., 1987, p. 87.

138 TRAVASSOS, Mário. Op. cit., 1938, p. 43.
} 
dependência do porto de Buenos Aires para escoar sua produção, cujo transporte se realizava por via fluvial através da bacia do Prata ou por via terrestre pelos trilhos da rede ferroviária argentina ${ }^{139}$.

A instabilidade geográfica na Bolívia é decorrente da oscilação como um "pêndulo geopolítico", de um lado, a força de atração do pacífico na porção ocidental do seu território, dominado pelo Chile ${ }^{140}$, e do outro, a região oriental está ligada pelas bacias Platina (Argentina) e Amazônica (Brasil). Ainda nessa linha Travassos destacou:

[...] as bacias do Prata e do Amazonas disputam o planalto boliviano, luta que certos caprichos geográficos favorecem ora a uma, ora a outra dessas bacias. Não há como negar que o equilíbrio político sul-americano se definirá, num futuro bem próximo, segundo as oscilações do já famoso triângulo Cochabamba (influências andinas), Sucre (influências platinas) e Santa Cruz (influências amazônicas) $^{141}$.

No segundo caso, figura a Colômbia, pois a "instabilidade geográfica" da borda noroeste da América do Sul é a porta de entrada de influências externas que cobiçam os recursos naturais existentes no subcontinente ${ }^{142}$. Nesse contexto, a posição do canal do Panamá é geoestratégico porque permite a penetração de uma potência extra-regional no subcontinente sul-americano. Nas palavras de Mario Travassos:

O canal do Panamá - verdadeiro carrefour internacional - e o Mar das Antilhas - incubadora da influência yankee - exprimem bem o caráter das pressões que se exercem nessa extremidade do continente sul-americano. As linhas naturais de penetração, que os vales do Madalena e do Orinoco representam, dizem o resto ${ }^{143}$.

De acordo com Travassos, os maiores progressos da penetração dos interesses estado-unidenses na América do Sul serão pelas vias andinas, ao longo da costa do Pacífico. Para ele, “corroboram nosso prognóstico, além das facilidades fisiográficas, o fracionamento político do território"144.

\footnotetext{
${ }^{139}$ MELLO, Leonel Itaussu Almeida. Op. cit., 1987, p. 88. 29, 2015, p. 66).

${ }^{141}$ TRAVASSOS, Mário. Op. cit., 1938, p. 142.

${ }^{142}$ Ibidem, p. 52.

${ }^{143}$ Ibidem, p. 52-3.

${ }^{144}$ Ibidem, p. 79.
}

${ }^{140}$ A Guerra do Pacífico evidencia as pretenções do Chile em controlar dois portos geoestratégicos da Bolívia, com saída para o oceano Pacífico: Arica e Antofagasta. A cobiça internacional das riquezas encontradas na Bolívia implicou na balcanização do seu território. A questão do Acre e a Guerra do Chaco também demonstram empiricamente essa tese. Respectivamente, para Chile, Brasil e Paraguai. Seu desfecho mais recente foi o mal-estar diplomático no Itamaraty diante da desapropriação, em 2006, dos ativos da Petrobrás na Bolívia, seguido, no ano seguinte, do aumento do preço do gás exportado ao Brasil pelo gasoduto boliviano-brasileiro (Gasbol). (ALBUQUERQUE, Edu Silvestre de. 80 anos da obra projeção continental do Brasil, de Mário Travassos. Revista do Departamento de Geografia, São Paulo, v. 
Por fim, o geógrafo brasileiro Edu Albuquerque explica que o Uruguai é o terceiro caso de instabilidade geográfica, "cujo relevo o enquadra no território brasileiro e a hidrografia ao território argentino"145. A única fronteira terrestre do Uruguai é com o estado brasileiro do Rio Grande do Sul, no norte. Para o oeste, encontra-se o rio Uruguai e a sudoeste situa-se o estuário do rio da Prata, delimitando a sua fronteira com a Argentina. Por essa razão, emerge como Estado-tampão, ou como dizia Leonel Itaussu, um "algodão entre cristais" para assegurar o equilíbrio de poder na região entre o Brasil e a Argentina ${ }^{146}$. Sobre essa instabilidade geográfica, Travassos escreve que o Uruguai possui com "o Brasil, laços sentimentais entretidos pela simplicidade de interesses pastoris e agrícolas. Com a Argentina algo de mais importante, interesses comerciais e militares, criados e homogeneizados pelo Prata e seu estuário"147.

Finalmente, Travassos salienta que o Estado brasileiro tem dimensões continentais. O país ocupa um espaço (raum) na América do Sul, que corresponde a 47,6 \% do território do subcontinente, com cerca de 8,5 milhões de $\mathrm{km}^{2}$ de terras emersas e 4,5 milhões de $\mathrm{km}^{2}$ de terras imersas, totalizando 13 milhões de $\mathrm{km}^{2}$. Seus 16,9 mil km de extensão, dos quais aproximadamente 12 mil correspondem à fronteira da Amazônia Legal, fazem fronteira com 9 países sul-americanos e um território ultramarino da França. O litoral brasileiro se estende por cerca de 7,4 mil km. No Atlântico Sul brasileiro, cruzam-se importantes rotas de navegação, vitais para a economia nacional. Aí estão localizadas as reservas do pré-sal brasileiro, de alto significado geoeconômico, geopolítico e geoestratégico ${ }^{148}$. Ora, se a tese ratzeliana de que "espaço é poder" continua atual, então o Brasil é, de certa forma, a potência regional, devido aos fatores geográficos apresentados acima.

Contudo, Travassos ressaltou que os Estados Unidos estão presentes no subcontinente. Para ele, o domínio estado-unidense do Caribe viabilizou a geoestratégia yankee de utilizar o canal do Panamá como vértice no roteiro Atlântico Norte/Pacífico Sul para chegar à costa oeste do território sul-americano. Em suas próprias palavras:

$\mathrm{Na}$ caracterização que vimos de fazer do mar das Antilhas, como mediterrâneo americano, focalizamos seu papel funcional como incubadora do extravasamento do potencial econômico e político dos Estados Unidos. Acabamos de ver como as características marítimas extremadas desse

\footnotetext{
145 ALBUQUERQUE, Edu Silvestre de. Op. cit., 2015, p. 68.

${ }^{146}$ MELLO, Leonel Itaussu Almeida. Op. cit., 1987, p. 90.

147 TRAVASSOS, Mario. Op. cit., 1938, p. 55.

148 BRASIL. Ministério da Defesa. Livro Branco de Defesa Nacional. Brasília, 2012, p, 17.
} 
mediterrâneo se adaptaram bem as necessidades da expansão yankee e como o canal de Panamá representa o papel de centro de todas as atuações desta política [...]. Está mais que evidente a possibilidade de o potencial yankee exceder o recipiente antilhano e canalizar-se por onde for mais fácil e necessário escoarem-se os seus interesses econômicos ${ }^{149}$.

Disse ainda Travassos:

Embora não seja fácil prognosticar, tudo faz crer que os maiores progressos
da infiltração dos interesses norte-americanos em nosso continente se farão
pelas vias andinas e ao longo da costa do Pacífico. Corroboram nosso
prognóstico, além das facilidades fisiográficas, o fracionamento político do
território. Além disso, é o meio mais seguro e o caminho mais direto para ir
das Antilhas ao planalto boliviano, verdadeiro centro geográfico do
continente do sul ${ }^{150}$.

Para o geopolítico brasileiro, a fragmentação político-territorial da costa oeste da América do Sul aliada aos fatores fisiográficos, em particular, os rios Magdalena e Orinoco, permitem a penetração da influência norte-americana no subcontinente ${ }^{151}$. Nesse sentido, Henry Kissinger assinala que o canal do Panamá é uma área geoestratégica, pois permite que a Marinha americana passe do Atlântico para o Pacífico sem precisar circum-navegar em torno do cabo Horn ${ }^{152}$. Por essa razão, o presidente Theodore Rosevelt (1901-1909) financiou a construção do canal, em 1904, no contexto de sua Big Stick Policy, cujo objetivo era justamente ampliar a sua zona de influência para além dos limites do mar do Caribe concretizando, assim, a Doutrina Monroe, que tinha como slogan "América para os americanos". Consolidando, dessa maneira, a hegemonia estado-unidense do Alasca à Terra do Fogo.

As ideias centrais de Travassos consistem no estabelecimento de dois sistemas de comunicações: transversais e longitudinais. O sistema transversal visava assegurar o controle do heartland sul-americano por meio dos corredores de exportação. Ainda nessa linha, os passos e nudos ampliariam a área de influência do Brasil até no Pacífico. Já o segundo sistema de comunicações, denominado longitudinal, buscava a unidade territorial do país por meio da utilização de duas regiões naturais brasileiras: o Nordeste Subequatorial e a Vertente Oriental dos Planaltos.

\footnotetext{
149 TRAVASSOS, Mario. Op. cit., 1938, p. 75-6.

${ }^{150}$ Ibidem, p. 79.

${ }^{151}$ Ibidem, p. 47, 52-3.

${ }^{152}$ KISSINGER, Henry. Ordem mundial. Rio de Janeiro: Objetiva, 2015, p. 253.
} 
Segundo Wanderley Messias, “a análise geopolítica de Travassos não é apenas pioneira como original nesse tipo de discurso no país"153. Para Shiguenoli Miyamoto, Travassos inegavelmente constitui um 'divisor de águas' nos estudos sobre a geopolítica no Brasil. Embora considere relevantes as obras de Backeuser, para ele, foi somente depois de 1931, que surgiu "uma análise sólida do papel a ser exercido pelo país em termos internacionais" $" 154$.

De acordo com André Martin, o pensamento de Travassos não está comprometido diretamente com a corrente "organicista" da Escola Alemã, mas sim com a "estruturalista", no sentido de que esta buscou analisar o espaço e a posição do Brasil e da placa continental sul-americana, como "elementos estruturantes do território"155.

\subsubsection{Influência de Mackinder}

Entre os geopolíticos brasileiros contemporâneos não há duvida de que a obra Projeção Continental do Brasil, de Travassos, foi influenciada pela teoria do pivot geográfico da história de Mackinder ${ }^{156}$. Essa hipótese se confirma pelo fato de ele considerar o triângulo econômico do planalto boliviano (Cochabamba-Santa Cruz de la Sierra-Sucre) o heartland da América do Sul. Conforme assevera Leonel Itaussu:

\footnotetext{
No campo intelectual, a geopolítica de Travassos sofreu uma influência determinante de Mackinder, com sua teoria sobre o poder terrestre. Essa teoria foi reelaborada e aplicada de forma criadora às condições peculiares do continente sul-americano, com o planalto boliviano assumindo o papel de área-chave com importância análoga à do "heartland" euro-asiático. Para Travassos, o controle da Bolívia, região-pivô do continente, outorgaria ao Brasil o domínio político-econômico sul-americano ${ }^{157}$.
}

Antes de estabelecermos uma relação entre as abordagens teóricas desses dois autores, será necessário atentarmos para a minúcia da teoria do pivot geográfico da história de Mackinder a fim de compreendermos profundamente as suas principais ideias e conceitos.

\footnotetext{
${ }^{153}$ COSTA, Wanderley Messias da. Op. cit., 2013, p. 198.

${ }^{154}$ MIYAMOTO, Shiguenoli. Op. cit., 1981, p. 64.

${ }^{155}$ MARTIN, André Roberto. Op. cit., 2007, p. 44.

${ }^{156}$ COSTA, Wanderley Messias da. Op. cit., 2013, p. 197; PENHA, Eli Alves. Op. cit., 1993, p. 33; MIYAMOTO, Shiguenoli. A geopolítica e o Brasil potência. Marília: UNESP, Faculdade de Educação, Filosofia, Ciências Sociais e da Documentação. 1985. (Séries Monográficas. Relações Internacionais, 4), p. 11

${ }^{157}$ MELLO, Leonel Itaussu Almeida. Op. cit., 1987, p. 72-3.
} 
Halford John Mackinder (1861-1947), quando criou a teoria do "pivot geográfico da história", em 1904, buscou compreender o momento histórico geográfico que o mundo atravessava naquela época. A sua genialidade consiste em perceber que o início do século XX seria marcado pelo final da era colombina, isto é, a era dos descobrimentos, que fora iniciada por Portugal no século XV e concluída no final do século XIX, quando o continente antártico foi circo-navegado, havendo, logo em seguida, as primeiras expedições em direção ao polo sul ${ }^{158}$. Para Mackinder, nesse "sistema político fechado", não havia mais nenhum espaço a ser descoberto, consequentemente, qualquer nova tentativa de regionalização do espaço mundial em termos geográfico-políticos implicaria em conflitos entre potências em expansão em relação a outras ${ }^{159}$. Diante desse contexto marcado por incertezas, ele previu a Primeira Guerra Mundial.

Em seguida, Mackinder buscou identificar qual era a potência perturbadora desse novo cenário geopolítico mundial que se desenhava no início do século XX. De acordo com Eric Hobsbawm, a Alemanha foi identificada facilmente como a potência perturbadora do equilíbrio de poder europeu, pelo fato de o país se tornar a "potência continental" após a sua unificação ${ }^{160}$. Moniz Bandeira afirma que a Alemanha em 1913, era a segunda potência industrial do mundo, atrás apenas dos Estados Unidos ${ }^{161}$. Apesar de ser uma potência econômica e possuir uma demografia expressiva, o país não tinha colônias. Por essa razão, em 1898, a Alemanha dá início a um programa de construção naval com capacidade de construir couraçados. O Kaiser Guilherme II buscava "um lugar ao sol", ou seja, uma posição de destaque para a Alemanha entre as grandes potências mundiais, mesmo que isso ameaçasse os interesses dos seus vizinhos ingleses e franceses ${ }^{162}$.

Diante desse contexto, marcado por essas duas tendências - final da era colombina e da emergência alemã - Mackinder propõe que os ingleses partissem para uma nova visão de mundo, pois temia que os triunfos alcançados pelo poder marítimo

\footnotetext{
${ }^{158}$ Palestra de Encerramento do Prof. Dr. André Martin no $3^{\circ}$ Simpósio Nacional de Geografia Política. Manaus, 07 a 10 de maio de 2013. Disponível em: $\langle$ https://www.youtube.com/watch?v=Dm8cVCtbObQ>. Acesso em: 03 nov. 2016.

${ }^{159}$ MACKINDER, Halford John. The Geographical Pivot of History. The Geographical Journal, London, v. 23, n. 4, apr., 1904, p. 421-2.

${ }^{160}$ HOBSBAWM, Erick John. A era dos impérios, 1875-1914. 18. ed. Rio de Janeiro: Paz e Terra, 2014, p. 485.

${ }^{161}$ MONIZ BANDEIRA, Luiz Alberto. Formação do império americano: da gerra contra a Espanha à guerra no Iraque. 4. ed. Rio de Janeiro: Civilização Brasileira, 2014, p. 61.

162PARKER, Geoffrey. Atlas da História do Mundo. 4. ed. São Paulo: Folha de São Paulo, 1995, p. 21.
} 
do seu país fizessem com que seus compatriotas se acomodassem em relação a sua hegemonia. Por essa razão, ele criou uma projeção cartográfica para ilustrar a nova reconfiguração do poder mundial que se apresentava naquele momento histórico geográfico. Na época, o mapa-múndi conhecido era feito com base na projeção de Mercator.

\section{Mapa 10: Projeção de Mercator}

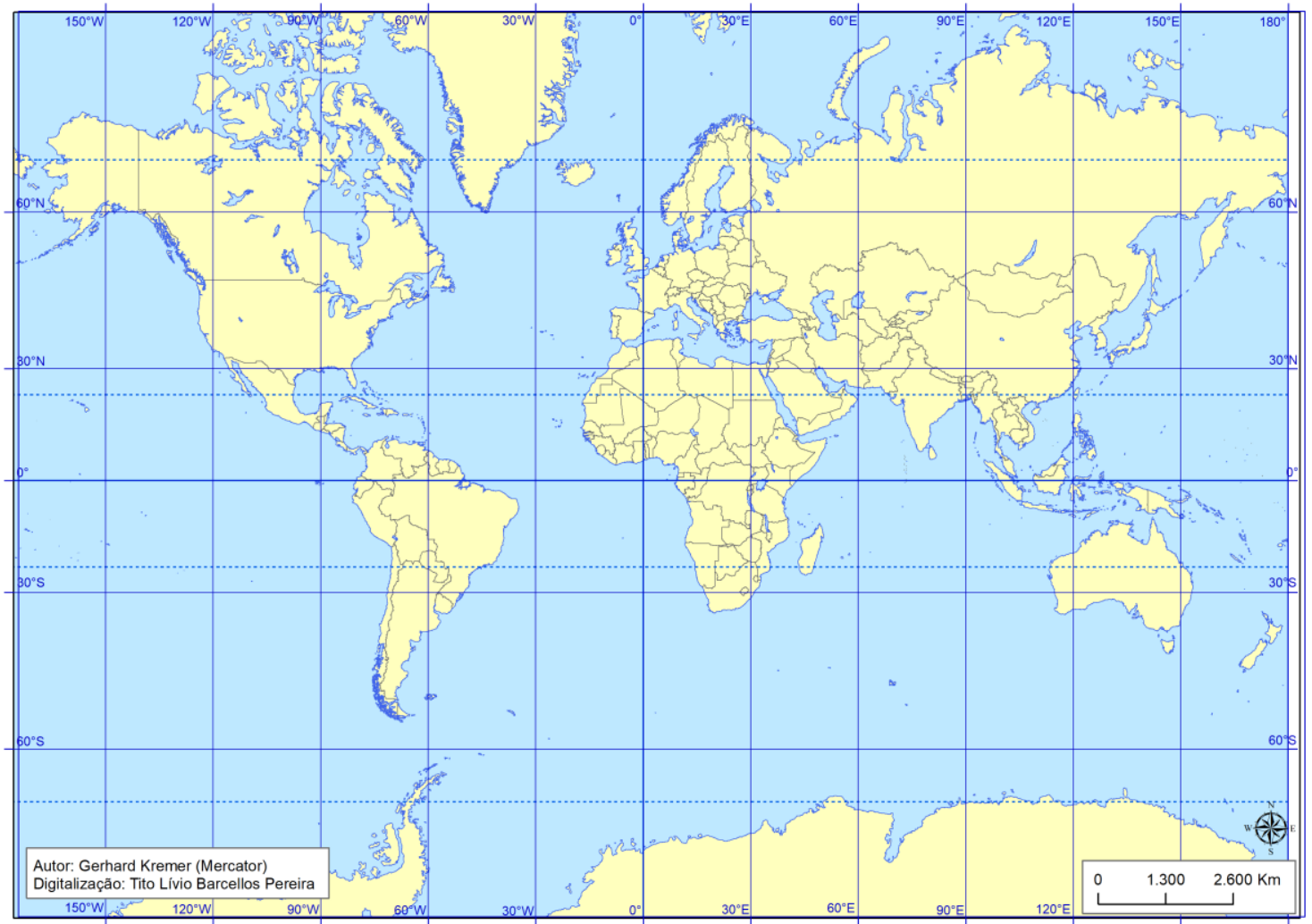

O mapa de Mercator possui duas grandes distorções: a primeira é seu caráter eurocêntrico, que coloca a Europa no centro do mundo. A segunda, ao fazer a projeção cilíndrica, as formas dos continentes são preservadas, mas as áreas estão distorcidas, porque conforme nos afastamos do Equador há o aumento da área relativa, dando a falsa impressão de grandeza do Hemisfério Norte, especialmente da Europa. Assim, a regiões de altas latitudes apresentam dimensões maiores que as dimensões reais. Observando o planisfério acima, vemos que a Groelândia, por exemplo, que tem cerca de 2,8 milhões de $\mathrm{km}^{2}$, aparece com quase o mesmo tamanho da África, com seus mais de 30 milhões de $\mathrm{km}^{2}$, já a Europa aparece no mapa com o mesmo tamanho que a América do Sul, mas na realidade, o continente europeu tem 10,5 milhões de $\mathrm{km}^{2}$ e a América do Sul 17,8 
milhões de $\mathrm{km}^{2}$. Portanto, a projeção de Mercator não corresponde com a realidade geográfica. Por essa razão, Mackinder abandonou o mapa de Mercator e construiu um novo mapa-múndi, dessa vez, centrado na Ásia, pelo fato de ser o maior dos continentes e geograficamente mais preciso, como se pode constatar no mapa 11.

\section{Mapa 11: Projeção de Mackinder}

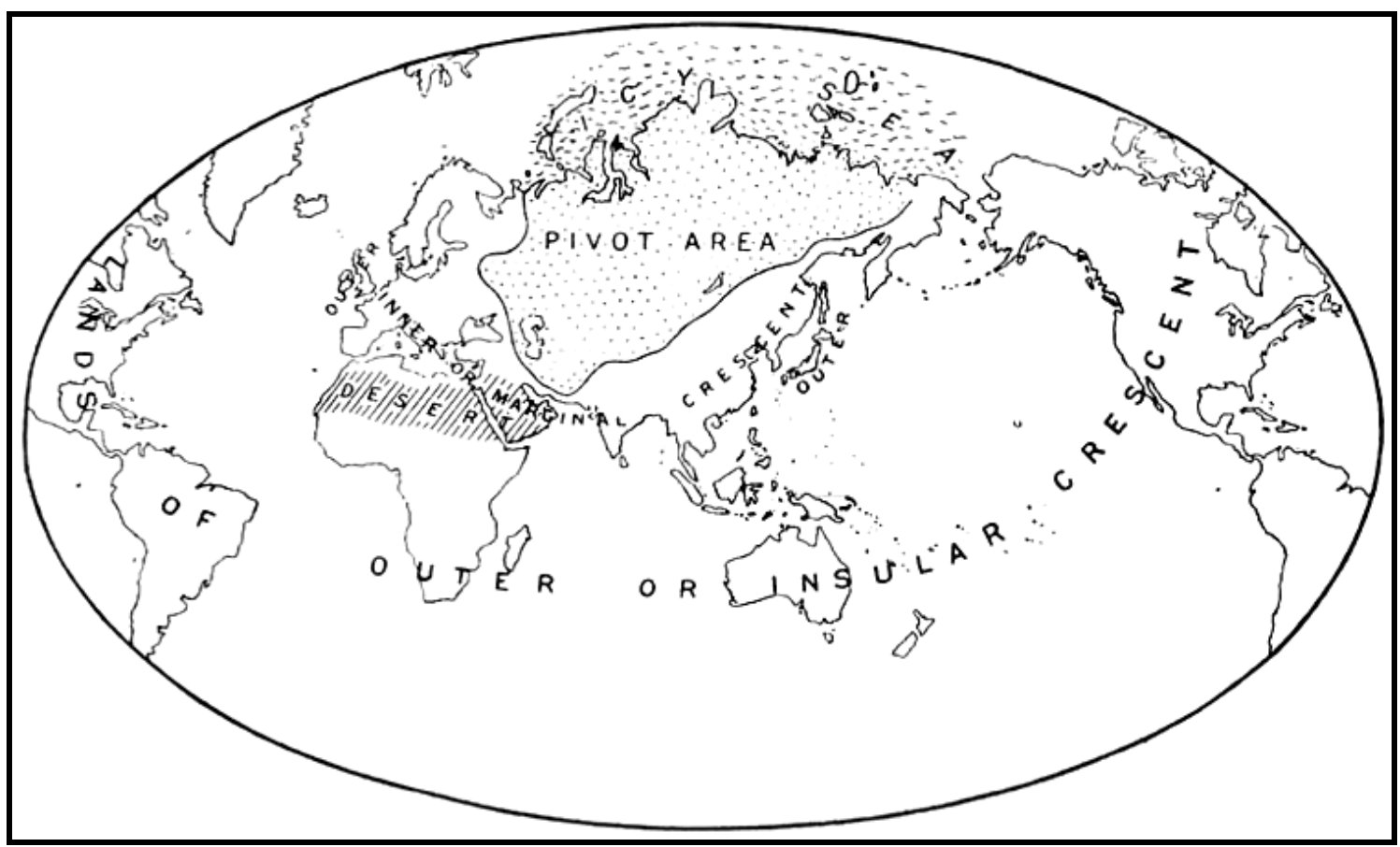

Fonte: MACKINDER, Halford John. The geographical pivot of history. Geographical Journal, 23, 1904.

Ao confeccionar um mapa-múndi com base na projeção azimutal "asiocêntrica", Mackinder descobre que a Europa é apenas uma península da Eurásia. Essa mudança de paradigma foi fundamental para ele criar o conceito de "pivot geográfico". Conforme assinalou André Martin:

Depois, com base numa análise histórica de longa duração, verificou que, nas grandes estapes da Ásia Central, localizava-se a fonte das grandes transformações mundiais, como provavam as duas ondas de invasões bárbaras que atingiram as grandes civilizações: a primeira com os hunos de Átila à época do Império Romano, e a segunda com os mongóis de Gêngis Khan, durante a Idade Média. Concluiu-se por fim que estas estepes eurasianas, abertas à movimentação da cavalaria, representavam "o pivot geográfico da História"163.

\footnotetext{
${ }^{163}$ MARTIN, André Roberto. Op. cit., 2004, p. 24.
} 
O termo pivot tem sentido de centro, de fulcro, de fonte principal das forças geopolíticas mundiais, porque justamente foram das esterpes eurasianas que partiram os movimentos dos mongóis influenciando a história mundial ${ }^{164}$. Essa grande região, situase no sentido norte-sul, das costas geladas do oceano Ártico aos desertos da Ásia Central; na direção leste-oeste, dos confins da Sibéria às terras situadas entre os mares Branco e Negro ${ }^{165}$.

Em seguida, ao fazer a projeção azimutal centrada nos países do Hemisfério Norte, Mackinder acaba identificando o oceano Ártico como uma zona de fronteira entre as duas grandes placas tectônicas - América do Norte e Eurasiática - que estão separadas por duas bacias oceânicas: o Atlântico Norte e Pacífico Norte. A primeira placa com vocação marítima e a segunda com vocação terrestre. Daí decorre a dualidade clássica da geopolítica entre o poder marítimo e terrestre ${ }^{166}$.

Ainda nessa linha, Mackinder identificou nas regiões periféricas do pivot geográfico um grande arco que denominou de "inner crescent" onde estão situados cinco países: a Alemanha, a Áustria, a Turquia, a Índia e a China, e em outro arco mais externo, que foi denominado de "outer crescent" encontram-se seis países: a GrãBretanha, o Canadá, os Estados Unidos, a África do Sul, a Austrália e o Japão ${ }^{167}$. Leonel Itaussu ressaltou a importância do Inner Crescent:

[...] o Inner Crescent era o espaço natural de expansão do poder terrestre que, de posse do núcleo basilar eurasiano, procurava conquistar as regiões periféricas e obter saídas para o oceano, tendo em vista a construção de um poder marítimo. Por outro lado, o Crescent Interno era também a barreira física de contenção ou a primeira linha de defesa do poder marítimo, que procurava conter a expansão do poder terrestre e mantê-lo encurralado no coração da Eurásia ${ }^{168}$.

Mackinder dizia também que o coração da Eurásia achava-se protegido contra eventuais invasões das potências marítimas, configurando uma verdadeira "fortaleza terrestre", que mais tarde ele denominaria de Heartland ${ }^{169}$. Mackinder adverte que se

\footnotetext{
${ }^{164}$ MACKINDER, Halford John. Op. cit., 1904, p. 428.

${ }^{165}$ MELLO, Leonel Itaussu Almeida. A geopolítica e o poder terrestre revisitada. Lua Nova, São Paulo, n. 34, dez. 1994, p. 57.

166 Palestra de Encerramento do Prof. Dr. André Martin no $3^{\circ}$ Simpósio Nacional de Geografia Política. Manaus, 07 a 10 de maio de 2013. Disponível em: <https://www.youtube.com/watch?v=Dm8cVCtbObQ>. Acesso em 03 nov. 2016.

167 MACKINDER, Halford John. Op. cit., 1904, p. 436.

${ }^{168}$ MELLO, Leonel Itaussu Almeida. Op. cit., 2015, p. 47.

169 MARTIN, André Roberto. Op. cit., 2004, p. 24. Em 1919, Mackinder apresenta a obra Democratic Ideals and Reality: A Study of Politics of Reconstruction, na qual ele deu uma nova roupagem a sua teoria
} 
essa área pivot fosse dominada por um único país (Rússia ou Alemanha), tornaria a potência terrestre numa potência anfíbia e, consequentemente, numa potência mundial, colocando em xeque a primazia naval britânica.

Em suas próprias palavras: "quem domina a Europa Oriental controla o Heartland. Quem domina o Heartland controla a World Island. Quem domina a World Island controla o mundo" ${ }^{\prime 170}$.

Por essa razão, após a Primeira Guerra Mundial, Mackinder propôs que as potências vencedoras criassem, na Europa Oriental, uma cadeia de Estados-tampão desde o mar Báltico até os mares Negro e Adriático para justamente separar a Alemanha da Rússia. No mapa 12 ele demonstra como ficaria o leste europeu.

do poder terrestre. Originalmente, a Eurásia foi denominada de pivot geográfico, mas após a Primeira Guerra Mundial essa grande região passou a ser chamada de "Heartland" (MACKINDER, Halford John. Democratic Ideals and Reality: a study in the politics of reconstruction. London: Constable and Company Ltd, 1919, p. 96). Por fim, em 1943, atendendo aos pedidos da Revista Foreign Affairs, ele retoma novamente a sua teoria, elaborada em 1904, demonstrando sua relevância e atualidade para a compreensão da conjuntura geopolítica marcada pela Segunda Guerra Mundial. Dessa vez, apresenta o conceito estratégico de "Heartland" como uma região central situada no interior da Eurásia e cria também o conceito de "Midland Ocean", este localizado na região do Atlântico Norte (MACKINDER, Halford John. The Round World and the Winning of The Peace. Foreign Affairs, New York, v. 21, n. 4, jul., p. 597, 602, 1943).

${ }^{170}$ MACKINDER, Halford John. Op. cit., 1919, p. 194. 
Mapa 12: O “Cordão Sanitário" mackinderiano (1919)

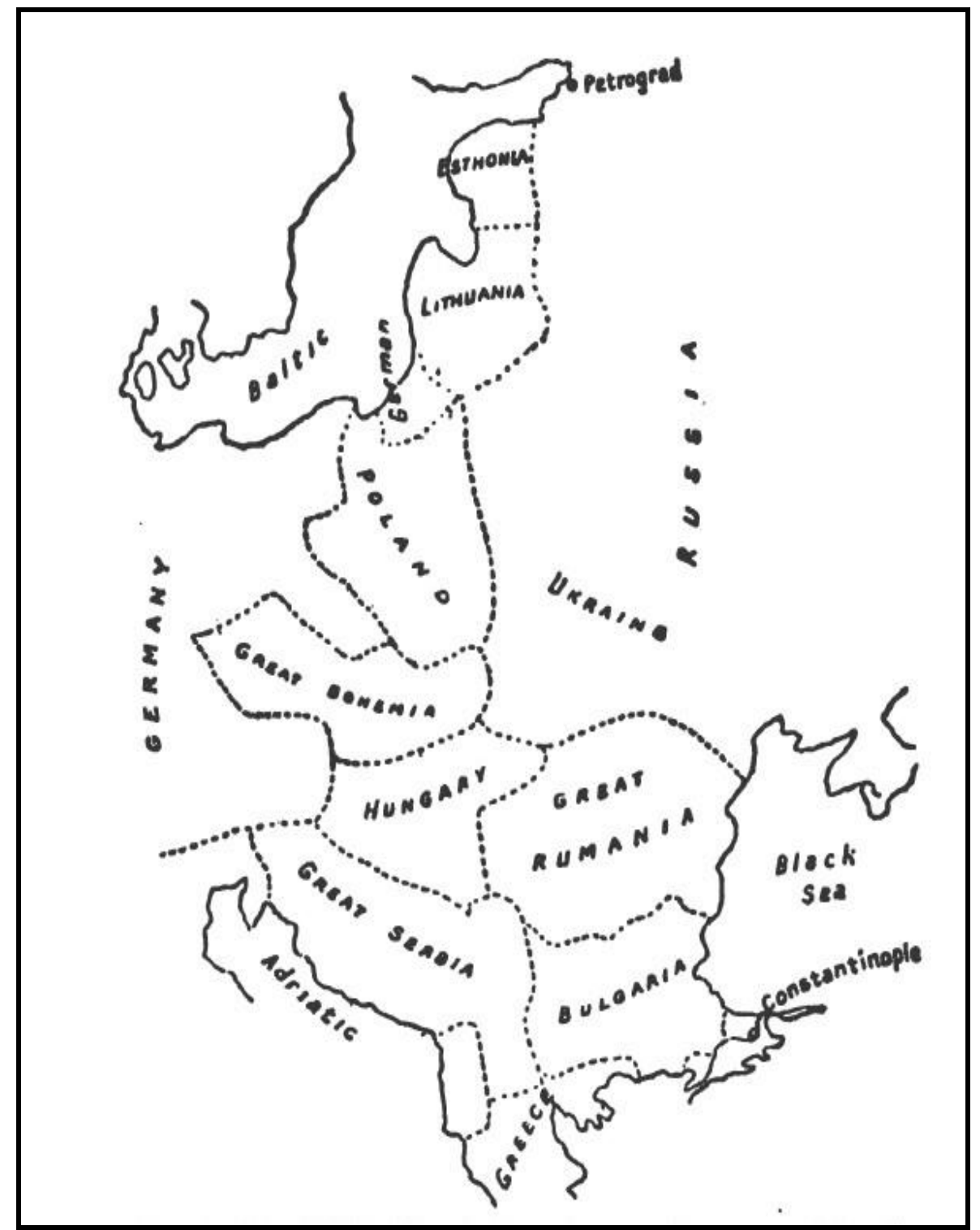

Fonte: MACKINDER, Halford John. Democratic Ideals and Reality. London: Constable and Company Ltd. 1919, p. 207.

A advertência de Mackinder foi de grande importância para redesenhar o mapa geopolítico europeu após a Primeira Guerra Mundial. Os Tratados de Versalhes e SaintGermain $^{171}$, que delimitaram as fronteiras da Europa, demonstram empiricamente essa tese (ver mapa 13).

\footnotetext{
${ }^{171}$ Em janeiro de 1919 é assinado o Tratado de Versalhes, que obrigou a Alemanha a fazer quatro concessões: 1) pagar pesadas indenizações; 2) o desmembramento de seu império colonial; 3) sua desmilitarização; e 4) perda territorial na Europa. Nesse mesmo ano é assinado o Tratado de SaintGermain que determinou: 1) desmembramento do Império Austro-húngaro; e 2) o surgimento de novos Estados - Polônia, grande Boêmia (Tchecoslováquia), Hungria e grande Sérvia (Iugoslávia). Somaram-se depois ao "cordão sanitário" os Estados bálticos - Estônia, Letônia e Lituânia - e a Finlândia. Já a
} 
Mapa 13: Europa após a Primeira Guerra Mundial (1921)

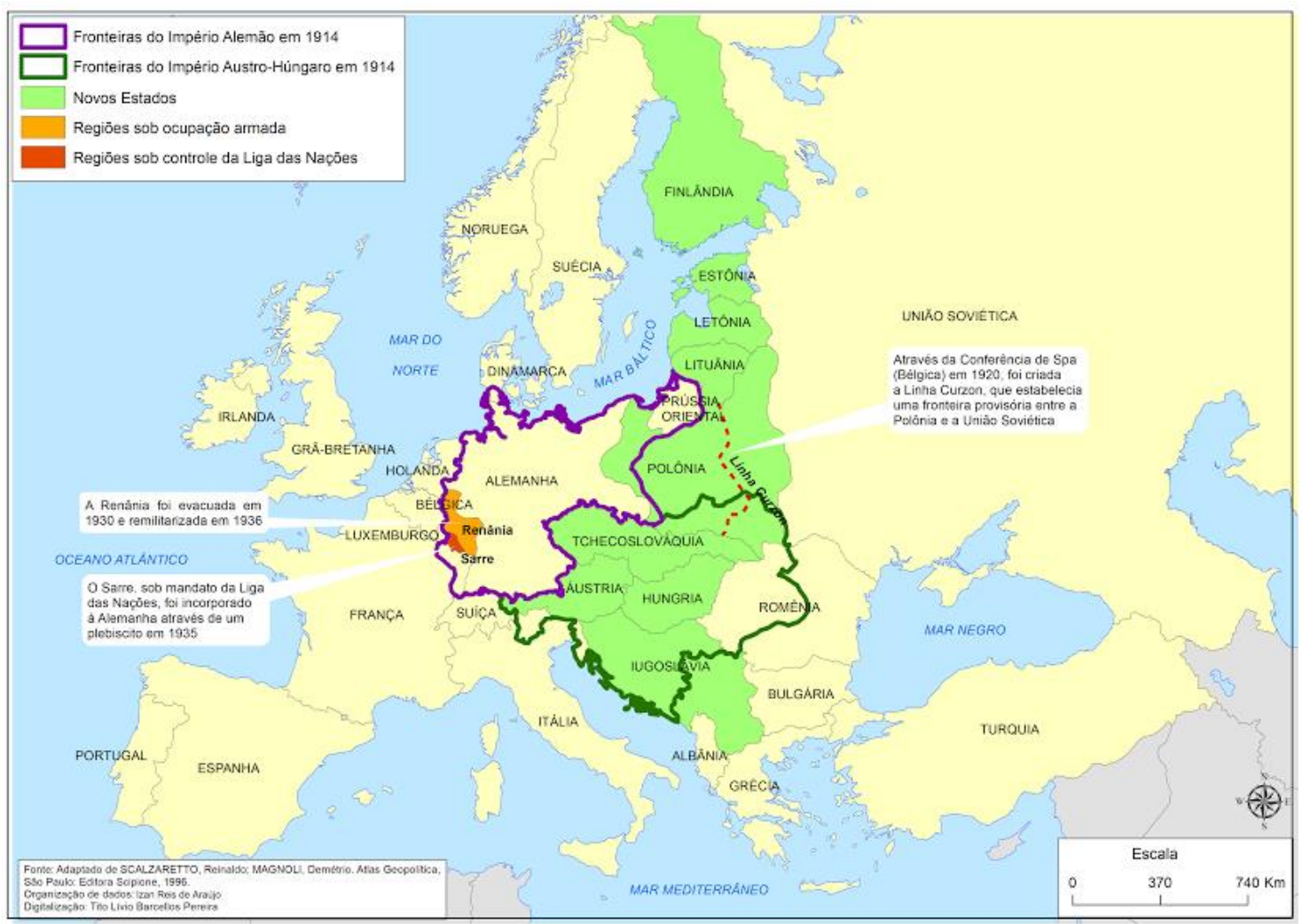

A função geoestratégica desse "cordão sanitário" era introduzir Estados-tampão entre a Alemanha vencida e a Rússia, impedindo uma futura aliança das duas potências terrestres que, devido ao seu potencial anfíbio, ameaçavam a balança de poder mundial e a pax britânica. Contudo, o Coronel Octavio Tosta lembra que o "cordão sanitário" fracassou, pois estava completamente desmantelado com o expansionismo da Alemanha nazista e da União Soviética. A Alemanha nazista anexou a Áustria ao seu território, em 1938. A seguir, os nazistas dominaram virtualmente a Tchecoslováquia. Em 1939, a Polônia é invadida simultaneamente pela Alemanha e pela União Soviética. Ainda nesse mesmo ano, os soviéticos atacaram a Finlândia e, em agosto de 1940, a Estônia, Letônia, e a Lituânia são incorporadas à União Soviética ${ }^{172}$.

As ideias de Mackinder não só influenciaram as grandes potências do Hemisfério Norte, como também, de certa forma, o Brasil, na obra de Mario Travassos. Não foi por acaso que ele seguiu a abordagem teórico-metodológica mackinderiana,

Áustria, foi desmembrada do Império Austro húngaro (SCALZARETTO, Reinaldo; MAGNOLI, Demétrio. Atlas Geopolítica, São Paulo: Editora Scipione, 1996, p. 12).

172 TOSTA, Octavio. Teorias geopolíticas. Rio de Janeiro: Biblex, 1984, p. 59-60. 
estava procurando obviamente trazer a questão do pivot geográfico para a América do Sul.

\subsection{Vargas e a articulação do espaço brasileiro na perspectiva travassiana}

A modernização centralizadora do Estado brasileiro inicia-se no governo de Getúlio Vargas que pôs fim à República Velha, em 1930. A centralização se identificaria com a ideia de unitarismo e autoritarismo, como no império, contrapondose fortemente ao federalismo ${ }^{173}$. Já a modernização se dará, por exemplo, com a criação dos Ministérios do Trabalho, Indústria e Comércio, da Educação e Saúde e, também assessorias técnicas permanentes em cada ministério ${ }^{174}$. O governo Vargas passou a formular políticas territoriais no país visando articular a integração nacional.

Conforme assinala Wanderley Messias:

De um modo não democrático, o "Estado Novo" inaugurava aqui essa nova conformação estatal: além do grande número de órgãos de regulamentação, controle e fomento, o governo passou a editar "planos" de desenvolvimento para o país. Tais são os casos do Plano Geral de Viação, do Plano Especial de obras Públicas e Aparelhamento da Defesa Nacional e do Plano especial de Obras e Equipamentos. Com eles, a era do planejamento econômico é inaugurado no país ${ }^{175}$.

Em 1934, o governo Vargas deu ênfase à infraestrutura de transporte, apresentando o Plano Geral de Viação Nacional visando não só apenas articular a integração das regiões do Brasil, mas também integrar os países vizinhos na perspectiva do modelo travassiano.

O General brasileiro Meira Mattos destaca a importância que as ideias de Travassos tiveram no governo Vargas:

As propostas geopolíticas sugeridas por Travassos, visando à articulação vial
do território foram, quase todas, incorporadas aos projetos de sucessivos
governos. Graças à realização do sistema de transportes carreadores para os
nossos portos dos interesses da imensa área interiorana brasileira, antes
submetida à atração hidroviária da bacia platina (Buenos Aires),
consolidamos a nossa integração territorial e construímos, nas nossas regiões

${ }^{173}$ MARTIN, André Roberto. As fronteiras internas e a "questão regional" do Brasil. Tese de Doutorado apresentada ao Departamento de Geografia da Faculdade de Filosofia, Letras e Ciências Humanas da Universidade de São Paulo. São Paulo, 1993, p. 179-80.

${ }^{174}$ COSTA, Wanderley Messias da. O Estado e as políticas territoriais no Brasil. São Paulo: Contexto, 1988 , p. 45.

175 Ibidem, p. 47. 
Leste, Sudeste e Sul, a mais importante base cultural e econômica da América Latina ${ }^{176}$.

Segundo Friederick Vieira, há uma sintonia entre as ideias de Travassos e o governo Vargas devido à aplicação empírica de suas ideias no sistema de transportes brasileiro $^{177}$, conforme se observa no mapa 14.

\section{Mapa 14: Plano Geral de Viação Nacional (1934)}

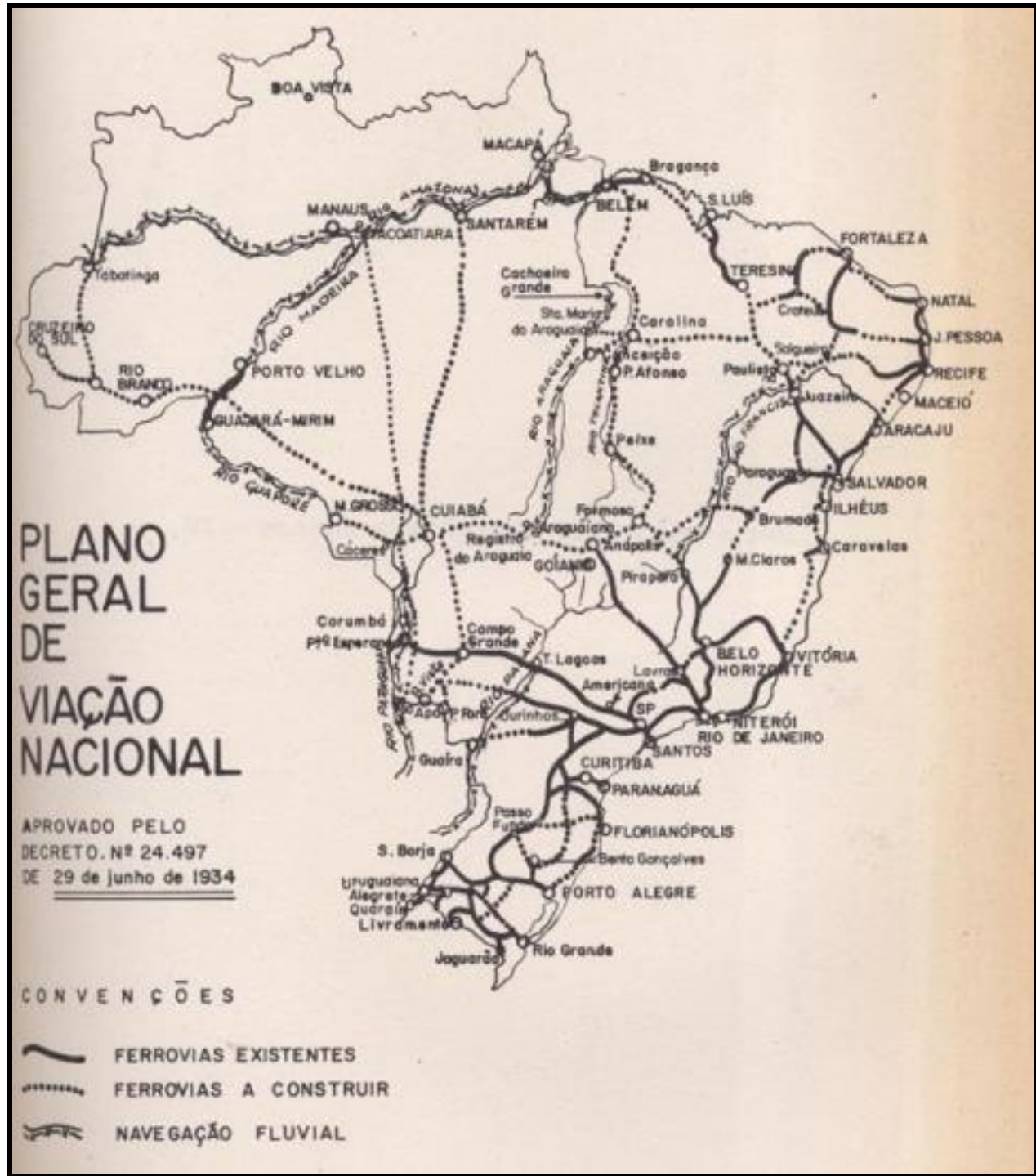

Fonte: VLACH, Vânia Rúbia Farias. Estudo preliminar acerca dos geopolíticos militares brasileiros. Revista Terra Brasilis. São Paulo, v. 4, n. 5, 2003, p. 5. 
O mapa 14 demonstra que os traçados do Plano Geral de Viação Nacional, de 1934, articulam os corredores de exportação norte e leste, e também as comunicações do Brasil longitudinal com o Brasil Platino e Amazônico.

No livro Introdução à Geografia das Comunicações, publicado em 1942, Travassos aprofunda a discussão em torno do problema das comunicações e dos transportes como um meio de assegurar a unidade política, desenvolvimento econômico e a soberania nacional. Ele elogia o Plano Geral de Viação Nacional, apresentado pelo governo Vargas, em 1934:

O Plano de Viação Nacional, sancionado em 29 de junho de 1934, deve ser considerado como a mais perfeita concepção circulatória que se poderia projetar para o nosso país. Seus traçados constituem, por assim dizer, a própria materialização das linhas de menor resistência ao tráfego do território, plena satisfação às características da geografia das comunicações brasileiras, admitindo o Brasil como um país continental-marítimo, de tipo longilíneo e banhado por um só mar, na forma da discussão que levamos à caracterização do seu tipo geográfico ${ }^{178}$.

De acordo com Vânia Vlach, o Plano Geral de Viação Nacional consiste não só apenas na primeira etapa de uma política nacional de comunicações, mas também leva em conta as condições geográficas do Brasil, além dos objetivos da política de comunicações que Travassos propõe para o país ${ }^{179}$.

Nas palavras de Travassos:

O fenômeno da convexidade nordestina e da excentricidade amazônica; a ação isolante da Serra do Mar entre o oceano e o interior, como ingrato espaço litorâneo; os diversos graus de acessibilidade do espaço litorâneo aos feixes de circulação marítima; as dificuldades para o estabelecimento de ligações longitudinais; todos esses complexos aspectos da geografia das comunicações brasileiras são fartamente atendidos, não só quanto à unidade política e bem-estar econômico como no da satisfação dos imperativos da defesa militar do país ${ }^{180}$.

O desenvolvimento de uma política de transporte multimodal é condição sine que non para favorecer a ocupação gradual do interior, e intensificar as relações entre as regiões brasileiras. Por essa razão, o Ministério da Viação e Obras Públicas da época criou uma comissão permanente com vistas a coordenar, da melhor forma, os trabalhos

178 TRAVASSOS, Mário. Introdução à Geografia das Comunicações Brasileiras (Ensaio). Rio de Janeiro: José Olympio, 1942, p. 195.

179 VLACH, Vânia Rubia Farias. Op. cit., 2003, p. 4-5.

180 TRAVASSOS, Mario. Op. cit., 1942, p. 202. 
relativos aos transportes ferroviários, rodoviários, fluviais, marítimos e aéreos ${ }^{181}$. Embora o Plano de Viação Nacional, criado no Governo Vargas, em 1934, seja de natureza multimodal, a prioridade do governo foi se revelando na modalidade rodoviária, especialmente depois da criação do Departamento Nacional de Estradas de Roldagem (DNER), em $1937^{182}$.

${ }^{181}$ Ibidem, p. 204.

${ }^{182}$ Transportes no Brasil - Síntese Histórica. Ministério dos Transportes, Portos e Aviação Civil, Brasília, 23 out. 2014. Disponível em: <http://www.transportes.gov.br/conteudo/54-institucional/136-transportesno-brasil-sintese-historica.html>. Acesso em: 3 jan. 2017. 


\title{
CAPÍTULO II - AMÉRICA LATINA: FORÇAS CENTRÍPETAS E FORÇAS CENTRÍFUGAS
}

\begin{abstract}
Es una idea grandiosa pretender formar de todo el mundo nuevo una sola nación con un solo vínculo que ligue sus partes entre si y con el todo. Ya que tiene un origen, una lengua, unas costumbres y una religión, deberia por consiguiente tener un solo gobierno que confederase los diferentes Estados que hayan de formarse; mas no es posible porque climas remotos, situaciones diversas, intereses opuestos, caracteres desemejantes dividen a la América.
\end{abstract}

Simon Bolívar (1815) 183

No segundo capítulo, abordaremos a América Latina com um enfoque multidisciplinar, problematizando a versão geopolítica e literária sobre a origem do termo. Em seguida, será apresentado, de um lado, o discurso do Pan-americanismo originário no monroísmo e, de outro lado, o hispano-americanismo na perspectiva do bolivarianismo e seus desdobramentos na arquitetura contemporânea de segurança regional. Por fim, destaca-se a nova reconfiguração geopolítica latino-americana no contexto das instituições de segurança regionais contemporâneas como a UNASUL e a CELAC.

\section{O conceito de "América Latina"}

Primeiramente, há na literatura uma discussão polêmica com várias posições divergentes em torno do conceito de "América Latina". Qual a sua origem? O que significa? Quais as intenções? Em que sentido o termo é usado e como ele acabou se consagrando? De modo que não há um consenso sobre a origem do nome, ou seja, quem foi o primeiro autor a utilizar a expressão "América Latina". O debate se desenvolve em torno de duas versões que explicam o seu nome: a primeira geopolítica e a segunda literária.

Na versão geopolítica, o termo “América Latina” foi cunhado pela primeira vez, em 1836, em um artigo do senador francês Michel Chevalier. O texto tem relação com o projeto expansionista de Napoleão III no México. Chevalier foi influenciado pelo geógrafo prussiano Alexandre von Humboldt que, já em 1825, mencionava que o "novo mundo", isto é, o continente americano estava dividido entre povos germânicos e

\footnotetext{
${ }^{183}$ BOLÍVAR, Simón. Carta da Jamaica. Toronto: Ed. Elaleph, 1999, p. 21. Disponível em:
} <http://www.cpihts.com/PDF/Simon\%20Bolivar.pdf >. Acesso em: 5 maio 2016. 
latinos. Com base nisso, Chevalier vai reforçar a ideia de Humboldt, dividindo a América nessas duas porções: América Anglo-Saxônica e América Latina.

Na América Anglo-Saxônica, predomina o inglês, uma língua de origem anglosaxônica. Já na América Latina, incluem-se todos os países da região onde predominam o espanhol, português e o francês, línguas originadas do latim. Com base nisso, Chevalier vai defender a ideia pan-latinista sob a alegação de uma suposta unidade linguística, cultural e étnica dos povos latinos, em contraposição aos anglo-saxões. Dessa maneira, a França visa ampliar a sua zona de influência para os países da região, inclusive o Brasil.

Como Chevalier estava engajado no projeto expansionista francês, ele vai influenciar Napoleão III, dizendo que em função dos Estados Unidos estarem invadindo terras latino-americanas, caberia à França como potência latina defender os países latino-americanos de tal agressão. A presente guerra civil americana (1861-1865) criou a situação propícia para que Napoleão III interviesse no México entre 1861 e 1867. Para Karl Marx, tal intervenção, sob o pretexto de reclamações monetárias, dos proprietários, de títulos, implicou no abandono de todos os preceitos do direito internacional ${ }^{184}$. Naquela ocasião, Napoleão III enviou um exército ao México e fez de Maximiliano dos Habsburgo imperador do México, entre 1864 e 1867, não obstante, os patriotas mexicanos derrotaram os franceses e fuzilaram o imperador Maximiliano.

Na versão literária, o nome "América Latina" foi criado pelos próprios hispanoamericanos e não foi um termo inventado de fora com conotações eurocêntricas neonapoleonicas ${ }^{185}$. Portanto, não seriam os franceses Michel Chevalier, em 1836, e tampouco Tisserand, em 1865, os seus autores. De acordo com essa versão, o chileno Francisco Bilbao teria sido o primeiro efetivamente a utilizar a expressão "América Latina" numa conferência em Paris, em 1856, intitulada Iniciativa de la América. Ele pensou no conceito de "América Latina" com vistas a unir os povos hispanoamericanos. No mesmo ano, o escritor e diplomata neo-granadino (colombiano) Torres Caicedo escreve Las dos Americas ${ }^{186}$. Já em 1861, Caicedo escreveu Liga latinoamericana, e por fim, o seu livro Unión latinoamericana foi publicado em 1865.

\footnotetext{
${ }^{184}$ MARX, Karl; ENGELS, Friedrich. Contribuição para uma história da América Latina. São Paulo: Edições Populares, 1982, p. 106.

${ }^{185}$ SCHWARTZ, Jorge. Abaixo Tordesilhas. Revista Estudos Avançados. S. Paulo, IEA - USP, n. 17, p. $187,1993$.

${ }^{186}$ Texto de TORRES CAICEDO, José María. Las dos Américas. Disponível em: <http://www.filosofia.org/hem/185/18570215.htm>. Acesso em: 13 out. 2015.
} 
Em oposição à versão literária, o analista político argentino Mariano Garcia Barace aponta que o conceito de "América Latina" não foi criado por Francisco Bilbao e Torres Caicedo, e tampouco deriva de uma perspectiva hispano-americana.

Em suas palavras:

\begin{abstract}
El caso de la conferencia de Francisco Bilbao es muy parecido al del poema "Las dos Américas" en el que J. M. Torres Caicedo también repite en um juego de palabras el concepto biracial de Chevalier. En ninguno de los casos se utiliza la expresión políticamente o para significar un área geográfico determinada. En ambos casos la palabra "latino/a" se utiliza sólo como un adjetivo para caracterizar racialmente a una parte de la población americana $^{187}$.
\end{abstract}

Embora haja uma polêmica em torno de quem dentre os quatros nomes: Michel Chevalier, Tisserand, Francisco Bilbao e Torres Caicedo seria o autor do conceito de "América Latina", o que se pode perceber é um compartilhamento entre eles e que, sem dúvida nenhuma, Chevalier foi um grande difusor e defensor do termo.

Um dos fatores que levaram à consagração da expressão "América Latina” foi porque a intelectualidade hispano-americana, isto é, a elite criolla, preferiu rejeitar o termo "hispano-América" que remetia à metrópole espanhola. Desse modo, eles passaram a utilizar no seu lugar o conceito de "América Latina" para assegurar a autoafirmação de sua identidade e independência política. Isso acaba sendo natural, tendo em vista que a identidade vem no primeiro momento pela rejeição do outro, ou seja, pela negação.

O mesmo aconteceu também com Portugal que foi o primeiro Estado moderno. A intelectualidade portuguesa formulou uma identidade própria que, para se realizar, identificava uma diferença em relação aos árabes e aos espanhóis. Para eles, ser português era viver na península ibérica, mas não sendo árabe e nem espanhol. No caso latino-americano, houve uma confluência de interesses entre as elites hispanoamericanas e estado-unidenses em favor do nome. Para os hispânicos, a expressão os diferenciava da metrópole espanhola. Já para os Estados Unidos, a expressão os diferenciava dos demais "latinos", garantindo o termo "americano" só para eles. Por esse motivo que vão apoiar o termo América Latina.

187 BARACE, Mariano Garcia. La expresión América Latina no fue creada por Francisco Bilbao. In: Posición Iberoamericana. Especiais intelectuales del Rio de la Plata. Buenos Aires, Argentina. Edición dez. 2011, p. 2. 
No Brasil, a polêmica se intensifica depois que o estado-unidense Richard Morse escreve o livro $O$ espelho de Próspero, publicado em 1988. Nele, o autor faz uma crítica ao termo América Latina, alegando que em função do conceito derivar de um projeto imperialista francês, precisa ser abandonado. Segundo Morse, seria preferível usarmos o nome "Ibero-América" em vez de "América Latina"188. Porém, se tal conceito foi adotado para justificar uma ação imperialista francesa na região, então por que quando a França é derrotada, no México, a expressão América Latina não cai em desuso, mas paradoxalmente é depois disso que o nome se consagra? Ademais, se aceitarmos o conceito de "Ibero-América", defendido por Morse, nós excluímos a França que teve um papel significativo na formação do continente americano. Tanto é assim que até o início do século XIX, o território da Nova França, Luisiana, é imenso, como se pode comprovar no mapa 15.

\section{Mapa 15: O território da Nova França (Luisiana) no início do século XIX}

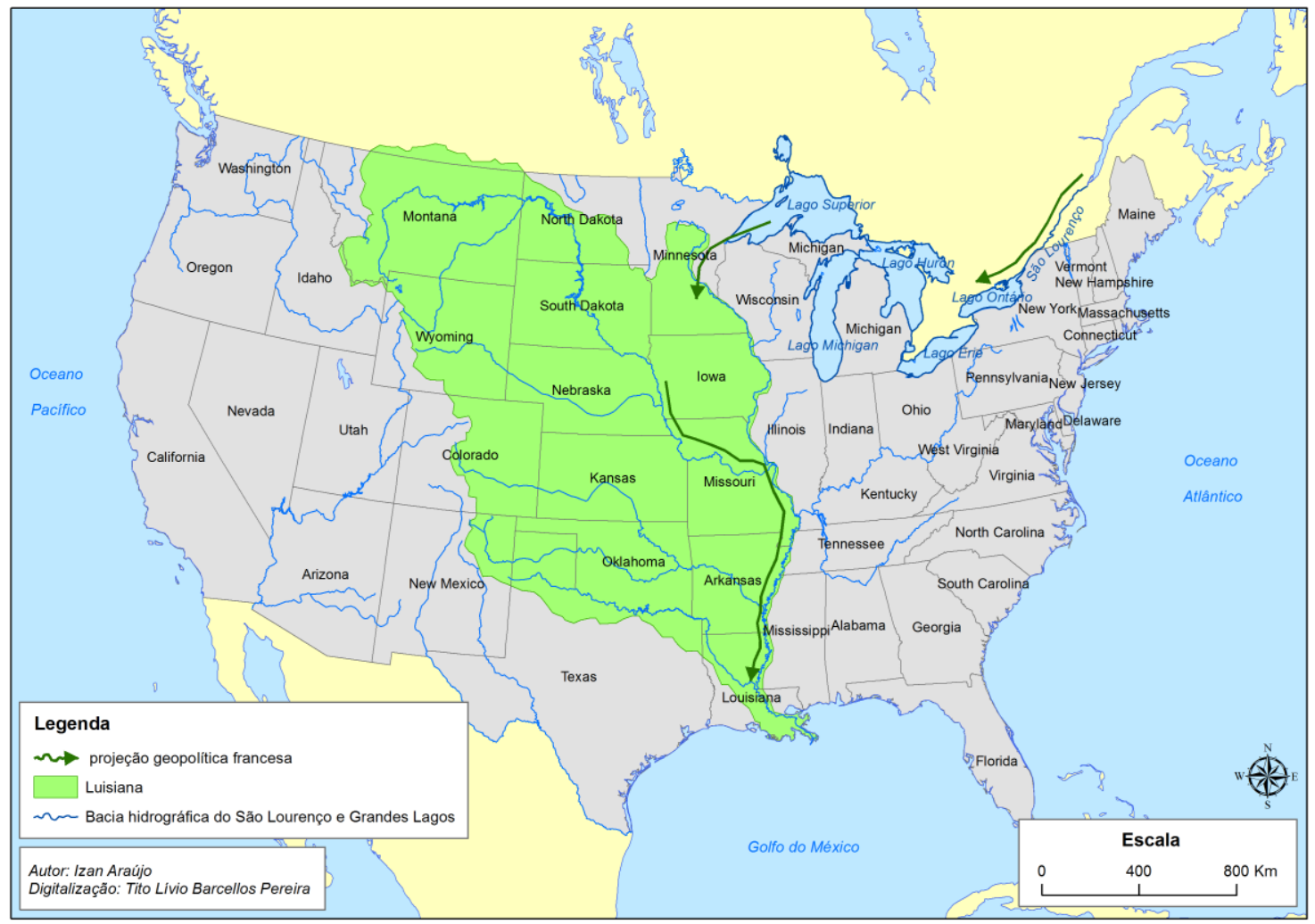

188 MORSE, Richard McGee. O espelho de Próspero: cultura e idéias nas Américas. São Paulo, Companhia Das Letras, 1988, p. 14. 
O mapa 15 mostra a dimensão da colonização francesa no continente americano. A própria descoberta da América do Norte é dos franceses que chegaram na região no século XVI ao buscarem uma rota para as Índias, do mesmo modo que os portugueses e os espanhóis. Os primeiros exploradores franceses chegaram através do estuário do rio São Lourenço colonizando aquela região, formando um arco com a Luisiana que saia no Golfo do México.

Ao conquistarem a porção norte do continente americano que corresponde hoje ao Canadá, onde fundaram Quebec, em 1607, o próximo passo foi dominar também a região chamada por eles de Luisiana, em homenagem ao rei francês Luis XIV. Somente mais tarde, os franceses foram perdendo espaço para os Estados Unidos e Inglaterra. $\mathrm{O}$ Território francês da Luisiana incluía muito mais do que o atual estado de Louisiana. Sua extensão territorial abrangia partes ou todas as regiões dos atuais estados de Louisiana, Arcansas, Missouri, Iowa, Minnesota, Dacota do Norte, Dacota do Sul, Nebrasca, Novo México, Texas, Oklahoma, Kansas, Montana, Wyoming e Colorado. Este território foi vendido pela França, em 1803, para os Estados Unidos.

Já na segunda metade do século XX, preocupado com a identidade latinoamericana, o mexicano Carlos Fuentes observa que a história da região inclui também povos indígenas pré-colombianos de origem inca, maia e asteca ou quéchua, e que eles não têm nada em comum com os europeus de modo geral, e nem com os africanos constituídos por diferentes grupos étnicos. Por isso mesmo, passou a pensar num conceito que expressasse essa diversidade étnico-cultural.

Em vista disso, ele criou o termo "Indo-Afro-Ibero-América" no livro Terra Nostra, publicado em 1972. Segundo o autor, esse termo seria mais apropriado e completo, pois o prefixo Indo compreende os elementos pré-colombianos (as diversas civilizações indígenas), Afro os que aqui foram trazidos após a colonização (africanos) e Ibero os colonizadores (os portugueses e espanhóis). Embora tal conceito seja mais correto do ponto de vista geohistórico, ele não foi muito aceito em função da dificuldade que as pessoas teriam em pronunciá-lo, visto que na maioria dos casos, elas preferem economizar as palavras. Ademais, o termo exclui as colônias francesa, inglesa e holandesa na região. 


\subsection{O Discurso do Pan-americanismo}

Os historiadores brasileiros Francisco Doratioto e Carlos Vidigal lembram que diferentemente do bolivarismo, o pan-americanismo tem suas origens na Doutrina Monroe, elaborada em 1823, que propõe a integração regional do continente americano sob a liderança dos Estados Unidos ${ }^{189}$. Tal iniciativa se constitui uma declaração unilateral proclamada pelo presidente estado-unidense James Monroe no Congresso Nacional, contrapondo o pensamento político bolivarista ${ }^{190}$.

Esse discurso do pan-americanismo se institucionalizou com a convocação da primeira conferência em Washington, em 1889, e no estabelecimento da União Panamericana, em 1910 ${ }^{191}$. Com a fundação da Organização dos Estados Americanos (OEA), em Bogotá, em 1948, se confirma a tese da hegemonia ${ }^{192}$ dos Estados Unidos em toda a América Latina. Durante a Guerra-Fria a organização passou a ser percebida pelos países latino-americanos como um instrumento a partir do qual o governo estadounidense operava para garantir seus interesses na região.

Para Wagner Menezes, dois movimentos distintos são identificados como geradores do pan-americanismo: “a ação estadunidense por meio do 'monroísmo' e o bolivarianismo materializado no Congresso do Panamá através de uma ação eminentemente hispano-americana" ${ }^{193}$.

189 DORATIOTO, Francisco Fernando Monteoliva; VIDIGAL, Carlos Eduardo. História das Relações Internacionais do Brasil. 1. ed. São Paulo: Saraiva, 2014, p. 79.

${ }^{190}$ O termo "bolivarista" refere-se ao pensamento do próprio Bolívar, enquanto que "bolivariano" diz respeito ao modelo dele. Igualmente os termos "marxista" e "marxiano", mas á é justamente ao contrário, se for o pensamento do próprio Marx, utiliza-se o termo "marxiano", mas se for o método é "marxista".

${ }^{191}$ BARRIOS, Miguel Ángel. Op. cit., 2009, p. 289.

${ }^{192}$ A palavra "hegemonia" comumente é utilizada para indicar o domínio de um país sobre outros, vinculando, assim, o uso a uma relação exclusivamente entre Estados. Às vezes, o termo "hegemonia" é empregado também como um eufemismo de imperialismo. Contudo, esses significados diferem do sentido gramsciano do termo, pois, para Gramsci, "hegemonia mundial" "é, em seus primórdios, uma expansão para o exterior da hegemonia interna (nacional) estabelecida por uma classe social dominante. As instituições econômicas e sociais, a cultura e a tecnologia associadas a essa hegemonia nacional tornam-se modelos a serem imitados no exterior. Essa hegemonia expansiva é imposta aos países mais periféricos como uma revolução passiva (COX, Robert W. Gramsci, Hegemonia e Relações internacionais: um ensaio sobre método. In: GILL, Stephen. (Org.). Gramsci: materialismo histórico e relações internacionais. Rio de Janeiro: Editora UFRJ, 2007, p.115, 118).

${ }^{193}$ MENEZES, Wagner. A contribuição da América Latina para o Direito Internacional: o Princípio da Solidariedade. Tese de Doutorado apresentada ao Programa de Pós-Graduação em Integração da América Latina (PROLAM) da Universidade de São Paulo. São Paulo, 2007, p.72. 


\subsubsection{Destino Manifesto e Monroísmo na política externa dos EUA}

Na primeira metade do século XVIII, já estavam constituídas as Treze Colônias ${ }^{194}$ inglesas da América do Norte, consideradas o núcleo geohistórico dos Estados Unidos. Já na segunda metade do século XVIII, o desejo dos sulistas de encontrarem mais terras adequadas ao cultivo do algodão acabaria resultando na "revolução" americana (1776-1783), que paradoxalmente espalhou a escravidão para além dos Apalaches. Isso não foi por acaso, o processo de independência havia sido liderado pelo fazendeiro George Washington e apoiado por uma elite de senhores de terras e de escravos que procuraram manter a estrutura existente. Mais tarde, essa expansão no sentindo leste-oeste terá como pressuposto o Destino Manifesto ${ }^{195}$.

\footnotetext{
${ }^{194}$ As Treze Colônias apresentavam diferenças nos processos de ocupação, nas atividades econômicas e nas relações com a Inglaterra. Nas regiões que correspondem ao norte e ao centro da costa leste, desenvolveram-se colônias de povoamento. Para Lenin, o desenvolvimento do capitalismo nessas regiões baseava-se na via "farmer", isto é, eram pequenas e médias propriedades agrículas policultoras e no trabalho livre e assalariado, essas colônias tinham a produção voltada para o mercado interno. Diferentemente no sul, estabeleceram-se colônias de exploração, denominado de "plantation". Ou seja, eram baseadas nas grandes propriedades agrícolas monoculturas e no trabalho escravo (latifúndios), com a produção voltada para o mercado externo. Contudo, segundo Lenin, com a Guerra Civil americana (1861-1865), os latifundiários, no sul, foram liquidados pela revolução, que confiscou e fragmentou as propriedades feudais deles. A partir daí, passou a predominar o camponês, que passa ser o agente exclusivo da agricultura e vai evoluindo até converter-se no granjeiro capitalista (LENIN, Vladimir Llitch. O Programa Agrário da Social-Democracia na Primeira Revolução Russa de 1905-1907. São Paulo: Livraria Editora Ciências Humanas, 1980, p. 30).

195 Segundo a construção ideológica do Destino Manifesto, os Estados Unidos seriam uma nação predestinada, com a missão de promover os valores do seu modo de vida para além de suas fronteiras, levando a liberdade e a prosperidade aos povos atrasados (AYERBE, Luis Fernando. Estados Unidos e América Latina: a construção da hegemonia. São Paulo: Editora Unesp, 2002, p. 52).
} 
Figura 1: O quadro denominado Progresso Americano de John Gast (1872)

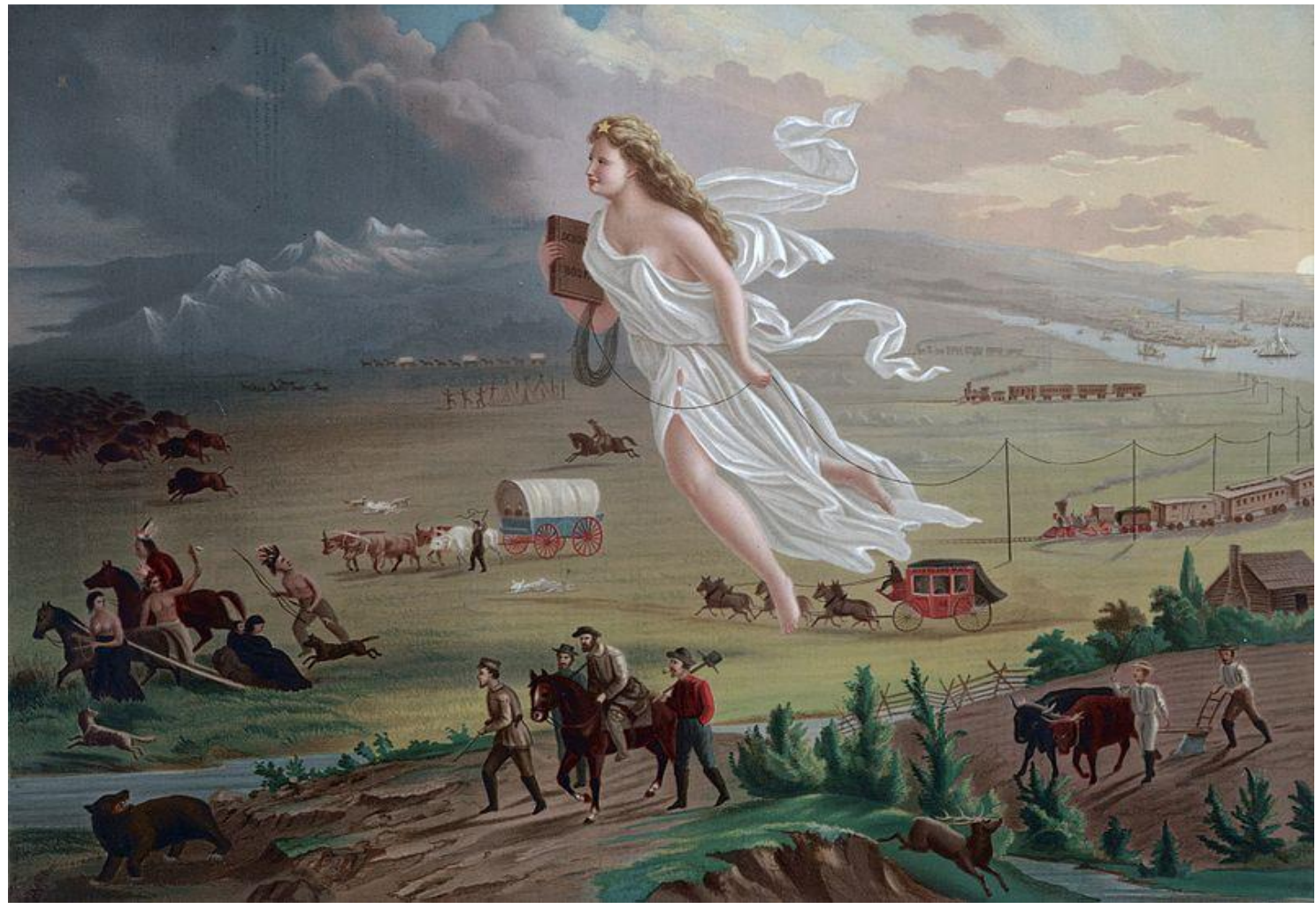

Fonte:https://pt.wikipedia.org/wiki/Doutrina_do_destino_manifesto\#/media/File:American_progress.JPG

Esse quadro de John Gast é uma representação alegórica do Destino Manifesto. Na cena, no claro, há uma mulher angelical, algumas vezes identificada como Colúmbia (uma personificação dos Estados Unidos no século XIX), carregando a luz da "civilização" juntamente com os colonizadores americanos, prendendo cabos telegráficos por onde passa. No escuro, há índios americanos e animais selvagens do oeste "oficialmente" sendo afugentados pela personagem ${ }^{196}$.

De acordo com André Martin, o termo "Destino Manifesto" acaba sendo um tanto contraditório por duas razões: primeiro porque o "destino" é algo desconhecido, oculto, que nós não temos o controle, que nos foge e escapa. Mas quando acrescenta a palavra "manifesto" significa que está revelado. Ou seja, na verdade, há uma intencionalidade nessa expressão. Qual é a sua finalidade? Justificar uma expansão

\footnotetext{
196 WEINBERG, Albert Katz. Manifest Destiny: A Study of Nationalist Expansionism in American History. In: CARVALHO, Maria Lucia Brant de. Das Terras dos Índios a Índios sem Terras. O Estado e os Guarani do Oco'y. Violência, Silêncio e Luta. Tese de Doutorado apresentada ao Departamento de Geografia da Faculdade de Filosofia, Letras e Ciências Humanas da Universidade de São Paulo. São Paulo, 2013, p. 534.
} 
territorial ${ }^{197}$. Tanto é assim, que Weinberg lembrou que a origem do termo Manifest Destiny ("Destino Manifesto") surgiu nos Estados Unidos, no contexto do conflito Texas/México. A frase foi criada pelo jornalista e diplomata nova-iorquino, John Louis O'Sullivan. Em 1845, ele escreveu um artigo na sua revista Democratic Review intitulado "Anexation", defendendo justamente a anexação do Texas pelos Estados Unidos $^{198}$. A partir daí a expressão Manifest Destiny passa a ser um conceito geopoliticamente útil para justificar a expansão dos Estados Unidos no oeste.

Weinberg acrescenta que, entre 1820 e 1830, latifundiários estado-unidenses começaram a invadir lentamente o Texas que pertencia à República do México, comprando terras, a preços muito baratos. Contudo, no México, a escravatura era proibida pela Constituição. Assim, os oligarcas estado-unidenses financiaram uma "revolução" e proclamaram a independência do Texas, em 1836. Depois foi feito um pedido formal de anexação ao país vizinho. Desta forma, em 1845, o Texas foi anexado pelos Estados Unidos ${ }^{199}$.

A expansão territorial dos Estados Unidos se deu em duas frentes geoestratégicas: leste-oeste e norte-sul. A primeira frente no sentido leste-oeste foi muito rápida e envolveu três etapas:

1) $\mathrm{O}$ Tratado de Versalhes ${ }^{200}$ com a Inglaterra, em 1783, que permitiu que os ingleses cedessem os seus territórios;

2) A compra da Luisiana (1803) e Flórida (1819) e

3) As guerras com o México, em 1848, que foi o principal prejudicado, e que acabou perdendo uma extensa área que vai do Texas à Califórnia.

Cabe ressaltar que a Inglaterra desejava retomar a sua colônia americana. Por essa razão, Thomas Jefferson e Napoleão Bonaparte fazem uma aliança. A França vende a Luisiana para os Estados Unidos, incentivando a marcha para o oeste (ver mapa 16).

\footnotetext{
197 Palestra do Prof. Dr. André Martin sobre "Meridionalismo: O Destino Manifesto Latino-americano" no Centro Russo-Brasileiro de Estudos da Multipolaridade (CEM), em 4 abr. 2017. Disponível em: $<$ https://www.youtube.com/watch?v=dWP5XI9L8ag\&list=PLCDAlADJ4vG_83tkPHaIJyTPZfgHfpqFF> . Acesso em: 22 maio 2017

${ }^{198}$ WEIBERG, Albert Katz. Op. cit., 2013, p. 533.

199 Ibidem, p. 532.

200 Em 1783, a Paz de Versalhes pôs fím à Guerra de Independência dos Estados Unidos contra a Inglaterra. Durante o conflito, os norte-americanos avançaram para o oeste, ocupando uma larga faixa de terras que atravessava o continente de norte a sul, entre a região dos Grandes Lagos e o golfo do México. O Tratado de Versalhes reconheceu a soberania estado-unidense sobre esse território, razão pela qual ele foi cedido pelos ingleses no mesmo ano.
} 
Mapa 16: Expansão territorial dos Estados Unidos (1776-1898)

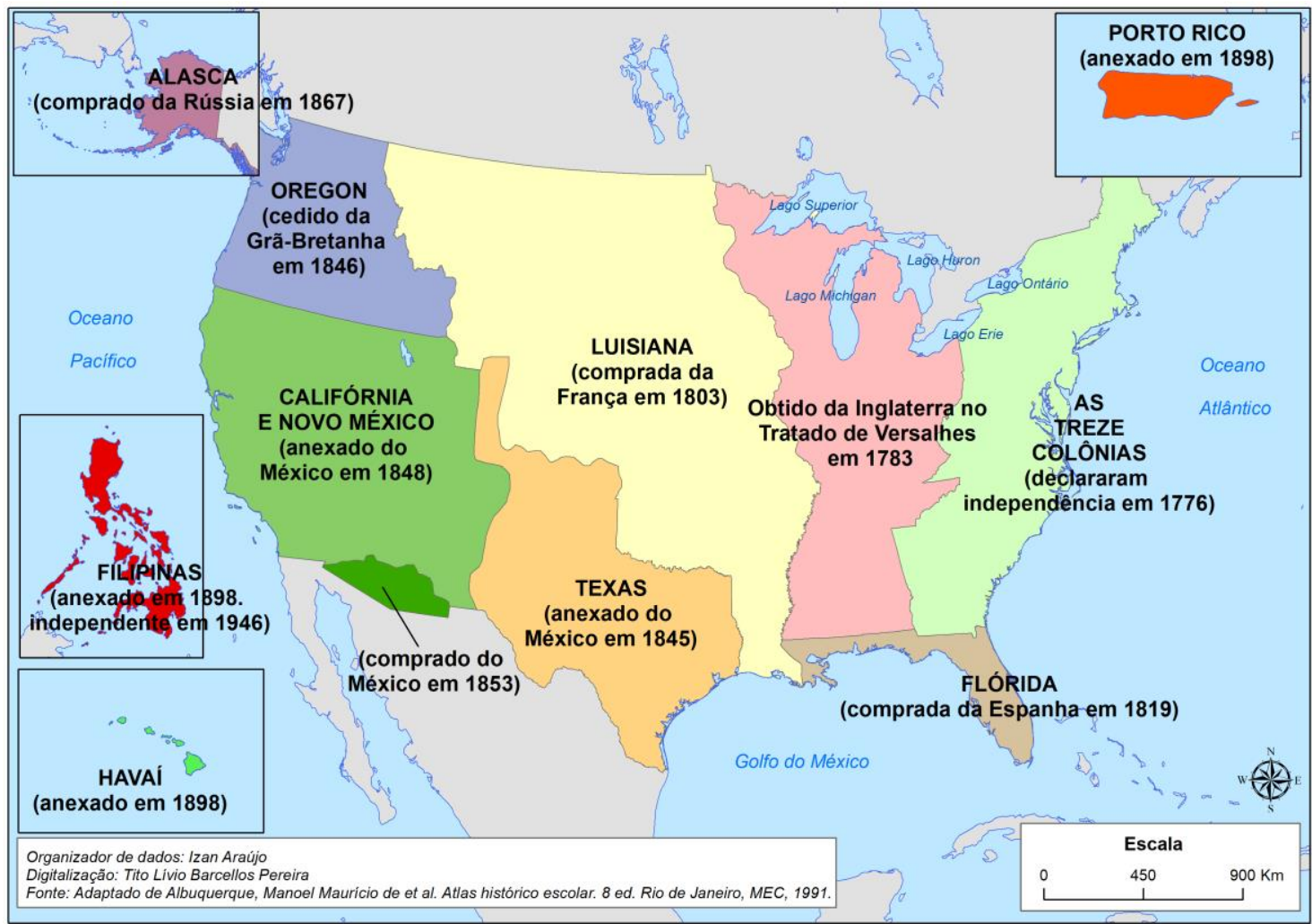

A ocupação do oeste implicou na extinção de vários povos indígenas que viviam na região das planícies centrais. Segundo Claude Fohlen, "havia uma incompatibilidade entre a instalação dos pioneiros e a manutenção da vida tradicional dos índios"201.

$\mathrm{O}$ vigoroso movimento expansionista direcionado para o oeste teve como consequência a incorporação de áreas contíguas ao oceano Pacífico, como o Oregon (1846), a Califórnia (1848) e o Alasca (comprado do Império Russo em 1867). Assim, os Estados Unidos tornam-se um país bioceânico, espraiando-se do Atlântico ao Pacífico, revelando uma grande potencialidade geopolítica de projetar poder no território externo em escala mundial via mares e oceanos.

Como observam Reinaldo Scalzaretto e Demétrio Magnoli:

Na década de 1880, as ideias do almirante Alfred Thayer Mahan, um dos grandes teóricos do poder naval, condicionaram o projeto marítimo que se desenvolveria. A anexação do Havaí pode ser vista como o primeiro ato de uma vasta operação, seguida imediatamente da guerra contra a Espanha, que possibilitou a hegemonia norte-americana sobre arquipélagos do mar do Caribe (Cuba e Porto Rico) e do oceano Pacífico (Filipinas). O auge desse processo foi a construção do canal do Panamá, precedida pela secessão da Colômbia e Panamá, sob cobertura dos Estados Unidos. O canal

${ }^{201}$ FOHLEN, Claude. O faroeste. São Paulo: Companhia das Letras, 1989, p. 146-7. 
interoceânico passava a funcionar como corredor entre as duas áreas do expansionismo naval norte-americano ${ }^{202}$.

A segunda frente do expansionismo americano foi no sentido norte-sul, espraiando-se do Alasca à Terra do Fogo. Nesse contexto, suas pretensões hegemônicas na América Latina são ameaçadas pela Ordem de Viena, que havia sido restaurada em 1815. Diante disso, com o pretexto de que essas potências extra-regionais representassem uma ameaça à integridade territorial das novas repúblicas hispanoamericanas, o presidente dos Estados Unidos, James Monroe, faz um pronunciamento no Congresso Americano, em 2 de dezembro de 1823, e lança a Doutrina Monroe ${ }^{203}$ proibindo qualquer intervenção europeia no continente americano.

Conforme afirma Héctor Gros Espiell:

Trata-se de uma doutrina unilateral dos Estados Unidos que jamais incluiu a América Latina, mas que, por seus múltiplos corolários, sempre impediu ao curso do século XIX e parte do XX a expansão europeia na América Latina, a fim de reservar sua política intervencionista, política que, de diferentes formas, sempre existiu. Mas, essa doutrina não impediu a ocupação militar das Ilhas Malvinas (Ilhas Falkland) pela Inglaterra em 1833, nem a intervenção francesa no México em 1860, nem as expedições punitivas para recuperação de dívidas em vários países, notadamente na Venezuela, em $1902^{204}$.

O pan-americanismo preconizado pela Doutrina Monroe foi um esforço dos Estados Unidos de tentar ganhar adeptos na América Latina para o projeto imperial americano, sob a alegação de que essa relação de dependência com os Estados Unidos era "benéfica" para os países da região, porque era o único jeito de evitar uma recolonização europeia, devido à restauração da Ordem de Viena. Embora esse fosse o discurso oficial da chancelaria americana, a transferência da soberania das ilhas

\footnotetext{
${ }^{202}$ SCALZARETTO, Reinaldo; MAGNOLI, Demétrio. Op. cit., 1996, p. 9.

${ }^{203}$ A Doutrina Monroe pode ser sintetizada na frase "América para os americanos", essa doutrina foi formulada por James Monroe, presidente dos Estados Unidos entre 1817 e 1825 para justificar o expansionismo estado-unidense no continente americano. Por meio dela, "o país proibia qualquer intervenção europeia na região. Também justificou a compra do Alasca até então pertencente à Rússia e o estabelecimento de uma relação de tutela com seus vizinhos ao sul do continente" (PIERI, Vitor Stuart Gabriel de; TELES, Reinaldo Miranda de Sá; OLIVEIRA, Fabiana de. Breve História da integração Latino-americana: entre o Monroísmo e o Bolivarianismo. Rio de Janeiro: Editora CENEGRI, 2015, p. 19).

${ }^{204}$ ESPIELL, Héctor Gros. La doctrine du Droit International en Amérique Latine avant la première conférence panaméricaine. (Washington, 1889). Journal of the History of International. Law, v. 3, 2001, p. 5.
} 
Malvinas dos argentinos para os ingleses, feita pelos Estados Unidos, no século XIX, demonstra empiricamente o contrário ${ }^{205}$.

De fato, não há evidências de que os Estados Unidos apoiaram o movimento independentista dos países hispano-americanos. Pelo contrário, quando eles enviaram tropas em apoio aos cubanos, que lutavam na Guerra de independência de Cuba (18951898), o objetivo do governo estado-unidense não era a emancipação da ilha, mas sim estabelecer a sua tutela sobre o país como fizeram com Porto Rico e Havaí, o que de fato ocorreu através da Emenda Platt ${ }^{206}$, que permitiu não só a ingerência deles na ilha caribenha, mas também a instalação da base militar de Guantánamo, que existe desde 1903, até hoje, como uma evidência do neocolonialismo dos Estados Unidos na América Latina. Portanto, os seus interesses na ilha não eram apenas econômicos, relacionados com o açúcar, o café e o tabaco, mas, sobretudo, geoestratégico.

Conforme assinala Moniz Bandeira:

\begin{abstract}
O governo americano percebia o domínio de Cuba como fundamental para a segurança das rotas no Golfo do México e para a defesa do canal que projetava abrir no istmo do Panamá havia quase cinquenta anos. Também o arquipélago das Filipinas, onde os nativos lutavam desde 1896 contra o domínio da Espanha, revestia-se de enorme importância estratégica, porquanto possibilitava a preponderância dos Estados Unidos nos populosos mercados da Ásia ${ }^{207}$.
\end{abstract}

Com a derrota da Espanha na Guerra Hispano-americana, o país assina o Tratado de Paris, em 10 de dezembro de 1898, renunciando à sua soberania sobre as antigas colônias no Caribe e no Oceano Pacífico. Nesse mesmo ano, os Estados Unidos recolonizaram Porto Rico, Havaí, Guam e as Filipinas ${ }^{208}$.

A Doutrina Monroe constituía, na verdade, em uma intervenção perigosa dos Estados Unidos e que era uma limitação da soberania das outras repúblicas, cuja causa a democracia de Washington nunca se irmanara. Os Estados

\footnotetext{
${ }^{205}$ Palestra do Prof. Dr. André Martin sobre "Meridionalismo: O Destino Manifesto Latino-americano" no Centro Russo-Brasileiro de Estudos da Multipolaridade (CEM), em 4 abr. 2017. Disponível em: $\langle$ https://www.youtube.com/watch?v=dWP5XI9L8ag\&list=PLCDAlADJ4vG_83tkPHaIJyTPZfgHfpqFF> . Acesso em: 22 maio 2017.

${ }^{206}$ A Emenda Platt foi um dispositivo legal inserido na Carta Constitucional de Cuba, que autorizava os Estados Unidos a intervir na ilha a qualquer momento que seus interesses fossem ameaçados. Somente depois da Emenda ser aprovada, em 1901, é que o país teve seu primeiro presidente eleito em 1902. O termo "Platt" deve-se ao fato da Emenda ser de autoria do senador estado-unidense Orville H. Platt.

${ }^{207}$ MONIZ BANDEIRA, Luiz Alberto. Op. cit., 2014, p. 47.

${ }^{208}$ Ibidem, p. 51.
} 
Unidos, vedando o continente à cobiça da Europa, não fizeram mais que reservá-lo para os futuros empreendimentos de sua ambição ${ }^{209}$.

Ainda nessa linha, a aquisição do Alasca pelos Estados Unidos faz parte desse expansionismo no sentido norte-sul. O império Russo possuía um território que se espraiava por três continentes (Europa, Ásia e América), porém, não havia contingente e nem capacidade militar suficiente para assegurar a defesa da integridade territorial do imenso país que já era pressionado na Ásia Central pelos mongóis, nos Bálcãs, pela Inglaterra, Áustria e o Império Otomano, e no Extremo Oriente pelos japoneses que vinham embalados pela "era Meiji” com uma marinha de guerra moderna.

Logo ficou claro que o país não seria capaz de manter ou defender o Alasca, por isso mesmo eles acabaram vendendo-o para os Estados Unidos a fim de evitar uma eventual quarta frente de batalha no continente americano, que levaria certamente a fragmentação do seu imenso território. Desta maneira, os norte-americanos barganharam o Alasca utilizando o pressuposto da Doutrina Monroe e seu slogan "América para os americanos", tranquilizando o império russo de que não tinham nenhum interesse na Eurásia, mas apenas no continente americano. Por conseguinte, em 30 de março de 1867, foi assinado, em Washington, o tratado que formalizou a venda do Alasca - cerca de 1,5 milhões de hectares russos - aos Estados Unidos por apenas 7,2 milhões de dólares ${ }^{210}$.

Assim, a política externa americana, no século XIX, foi marcada por dois conceitos-chave: o Destino Manifesto e a Doutrina Monroe. O primeiro para justificar a expansão leste-oeste, espraiando-se do Atlântico ao Pacífico e o segundo no sentido norte-sul do Alasca à Terra do Fogo.

No início do século XX, a Doutrina Monroe ganha uma nova roupagem com o presidente Theodore Roosevelt (1901-1909), que anunciou o "Corolário Roosevelt" no Congresso, em 6 de dezembro de 1904. Para Eli Penha, o "Corolário Roosevelt" defendia o direito dos Estados Unidos de empreenderem ataques preventivos contra Estados que se mostrassem "ineficientes" do ponto de vista de sua ordem interna, ou

\footnotetext{
${ }^{209}$ MONIZ BANDEIRA, Luiz Alberto. Presença dos Estados Unidos no Brasil: dois séculos de história. 2. ed. Rio de Janeiro: Civilização Brasileira, 1978, p. 150.

${ }^{210}$ MANAEV, Gueórgui. Por que a Rússia vendeu o Alasca aos Estados Unidos. Gazeta Russa. 3 abr. 2014. Disponível em: <http://br.rbth.com/arte/2014/04/03/por_que_a russia_vendeu_o_alasca_aos_eua_24975.html $>$. Acesso em: 15 jun. 2015.
} 
que ficassem "inadimplentes" do ponto de vista de suas dívidas externas ${ }^{211}$. A sua política externa intervencionista na América Central e no Caribe foi inspirada nos preceitos de um provérbio africano: "Speak softly and carry a big stick". (fale suavemente e carregue um grande porrete). Essa frase deu origem a expressão "Big Stick Policy” (ver figura 2).

Figura 2: Theodore Roosevelt e sua política do Big Stick no Caribe (1904)

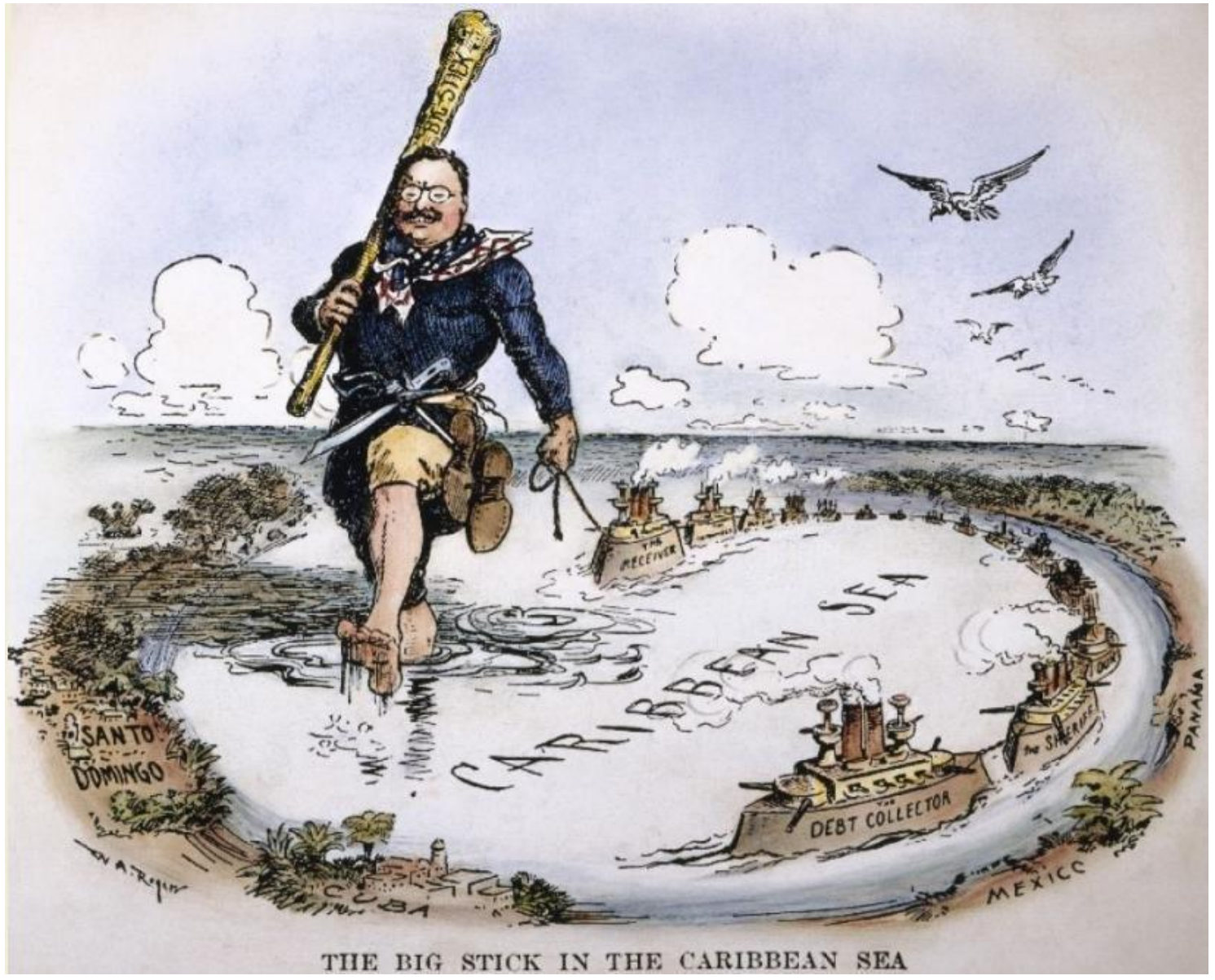

Fonte: https://pt.wikipedia.org/wiki/Big_Stick

A figura acima ilustra muito bem como foi a política do Big Stick dos Estados Unidos no Caribe. Sua atuação foi baseada num poder naval colossal com vistas a garantir os seus interesses comerciais na região. Essa projeção de seu poder marítimo surge com o almirante Alfred Thayer Mahan. Sua obra mais conhecida, A influência do poder marinho sobre a história, foi publicada em 1890.

211 PENHA, Eli Alves. Somos todos americanos? Unidade e Diversidade Regional nas Américas. Cadernos Prolam/USP, São Paulo, v. 14, n. 26, p. 63-76, 2015. 
Mahan defendia a tese de que a Doutrina Monroe não podia alcançar seus objetivos expansionistas no sentido norte-sul sem uma marinha poderosa ${ }^{212}$. Ele enxergava os Estados Unidos como uma "ilha geopolítica" - um Estado com saídas para os principais oceanos e sem ameaças territoriais nas suas faixas de fronteiras terrestres. Essa condição geográfica excepcional oferecia a possibilidade da expansão do "sea power".

Como resultado dessa geopolítica, observa o historiador Luís Fernando Ayerbe:

\begin{abstract}
Suas ideias terão grande influência entre políticos e intelectuais do país. Um dos seus discípulos mais ilustres será Theodore Roosevelt, que, como presidente, enuncia, em dezembro de 1904, o corolário para a Doutrina Monroe [...]. A política para a América Latina durante o governo Roosevelt (1901-1909) será conhecida como big stick, promovendo intervenções em vários países na América Central e Caribe ${ }^{213}$.
\end{abstract}

Diante disso, "os países latino-americanos ficaram alarmados, pelo real e crescente uso da força por parte dos Estados Unidos" ${ }^{\text {214 }}$. Um exemplo emblemático dessa política externa intervencionista e neocolonialista foi o apoio à independência do Panamá diante da Colômbia, na medida em que a o governo colombiano recusou os termos do governo norte-americano para a construção de um canal interoceânico que ligasse a costa atlântica à costa do pacífico.

A teoria do sea power de Mahan influenciou a elite americana. Seguindo suas orientações, a Marinha de Guerra dos Estados Unidos se expandiu durante o governo Roosevelt, passando do terceiro lugar no mundo para o segundo, atrás apenas da Inglaterra $^{215}$.

\title{
2.1.2. Bolívar e a sua geoestratégia contra-hegemônica
}

Considerado um dos principais expoentes do movimento independentista da hispano-América, Simón Bolívar foi um importante líder político e militar, nasceu em 24 de julho de 1783, em Caracas. Descendia de uma rica família, que na época da dominação espanhola constituía a nobreza criolla $^{216}$, na Venezuela, seu pai, dom Juan

\footnotetext{
212 TOSTA, Octávio. Op. cit., 1984, p. 38.

213 AYERBE, Luis Fernando. Op. cit., 2002, p. 53.

214 ALMEIDA, Paulo Roberto de. Sovereignty and Regional Integration in Latin America: A Political Conundrum? Contexo Internacional, v. 35, n. 2, p. 474, 2013.

${ }^{215}$ AYERBE, Luis Fernando. Op. cit., 2002, p. 54.

${ }^{216}$ Eram os descendentes dos espanhóis, nascidos na colônia, que compunham uma aristrocracia local.
} 
Vicente, faleceu de tuberculose em uma noite quente de janeiro de 1786, quando Simón não tinha nem três anos. Sua mãe, Maria de la Concepción Palacios y Blanco, morreu também de tuberculose, em 6 de julho de 1792, deixando-o órfão aos 9 anos. Em 1795, aos doze anos, o menino esteve sob a tutoria de Simón Rodriguez, um professor que admirava as obras de Rousseau, Locke, Voltaire e Montesquieu. Em 1799, aos 15 anos, os seus dois tios - Esteban Palacios e Carlos Palacios - resolveram que o jovem deveria ir estudar em Madri, Espanha. Em 1802, aos dezoito anos, casou-se em Madri e regressou à Venezuela, onde sua esposa faleceu repentinamente de febre amarela. Depois desse acontecimento, transferiu-se, em outubro de 1803, pela segunda vez, para a Europa. Em Paris, ele conheceu Alexander von Humboldt e se indignou com a coroação de Napoleão Bonaparte como imperador, em 1804. No ano seguinte, em Roma, Bolívar, seu professor Rodríguez e Fernando del Toro subiram o Monte Sacro até o seu cume, ali no topo, ajoelharam e todos os três, abraçados, juraram libertar a América da tirania espanhola ou morrer tentando fazê-1o ${ }^{217}$.

Ao regressar ao seu país de origem, em 1807, já com vinte e quatro anos de idade, estava convencido de que a América poderia ser livre, assim como os Estados Unidos e a França. Dessa maneira, ele passa a integrar guerrilhas de resistência frente ao domínio de Napoleão Bonaparte, que havia nomeado seu irmão, José Bonaparte, como rei da Espanha e de suas colônias, em 1808.

Em 1813, aos 30 anos, liderou o movimento independentista, invadindo a Venezuela, reconquistando a cidade de Caracas, em 6 de agosto do mesmo ano, sendo proclamado "El libertador".

Como assevera Marie Arana:

\begin{abstract}
Ninguém poderia duvidar de que as vitórias de Bolívar fossem estarrecedoras. Ele começara oito meses antes com menos de quinhentos homens e superara a formidável máquina de guerra da Espanha. Em contraste, Napoleão, com um colossal exército de 500 mil homens, estava saindo da Espanha mais ou menos à mesma época, a caminho de perder a guerra $^{218}$.
\end{abstract}

Quando Napoleão Bonaparte foi derrotado na batalha de Waterloo, em 1815, a Espanha tentou reconquistar as colônias, mas as forças emancipacionistas já estavam bem coesas e contavam com o apoio da Inglaterra que tinha interesse no mercado

${ }^{217}$ ARANA, Marie. Bolivar: o libertador da América. São Paulo: Três Estrelas, 2015, p. 27, 33, 36, 45, 47, 49-50, 60-1, 63-4, 70, 77-8.

${ }^{218}$ Ibidem, p. 158. 
consumidor da região. Foi diante desse contexto que Simon Bolívar comandou as guerras de independência de uma imensa faixa territorial das Américas - hoje correspondentes às fronteiras de seis países: a Venezuela (1819), a Colômbia (1819), o Panamá (1821), o Equador (1822), o Peru (1824) e a Bolívia (1825).

O movimento independentista se estendeu pela América Central até o México (1821), de modo que, em 1825, as únicas possessões espanholas na região eram Cuba e Porto Rico, que passariam ao controle dos Estados Unidos, em 1898, na Guerra Hispano-Americana.

De acordo com Aleixo, a independência da América espanhola era apenas parte do pensamento político bolivarista. Seu objetivo se completaria com um pacto de união entre as ex-colônias ${ }^{219}$.

$\mathrm{Na}$ Carta da Jamaica, Bolívar expressa essa ideia:

Es una idea grandiosa pretender formar de todo el mundo nuevo una sola nación con un solo vínculo que ligue sus partes entre si y con el todo. Ya que tiene un origen, una lengua, unas costumbres y una religión, deberia por consiguiente tener un solo gobierno que confederase los diferentes Estados que hayan de formarse; mas no es posible porque climas remotos, situaciones diversas, intereses opuestos, caracteres desemejantes dividen a la América ${ }^{220}$.

Assim como a Nova Inglaterra, ao unir o seu núcleo geohistórico de língua inglesa, faria nascer os Estados Unidos; a América Portuguesa, unindo o seu núcleo geohistórico de língua portuguesa, daria origem ao Brasil, do mesmo modo a GranColômbia de Bolívar também queria unir os núcleos geohistóricos de língua espanhola no continente americano ${ }^{221}$. Mas, a restauração das monarquias absolutistas europeias ameaça os planos de Bolívar. A Espanha poderia se aventurar, com o apoio da Santa Aliança, reconquistar as colônias na América; e a segunda ameaça era indubitavelmente os Estados Unidos, que com sua política externa pautada na Doutrina Monroe, propunha substituir a hegemonia europeia pela sua própria.

Diante desse cenário geopolítico desfavorável, Simon Bolívar convocou o Congresso do Panamá, que ocorreu do dia 22 de junho ao dia 3 de julho de 1826. Nessa reunião, ele apresentou sua proposta de criação de uma confederação baseada no "princípio da solidariedade” entre os Estados hispano-americanos com vistas a protegê-

\footnotetext{
219 ALEIXO, José Carlos Bradi. Visão e atuação internacional de Simón Bolívar. Revista de informação Legislativa. Brasília, v. 20, n. 80, p. 33, out./dez. 1983.

${ }^{220}$ BOLÍVAR, Simon. Op. cit., 1999, p. 21.

${ }^{221}$ CASTRO, Therezinha de. Op. cit., 1994, p. 237.
} 
los das ameaças estrangeiras, que pretendiam recolonizar a América Espanhola. No encontro, foi elaborada e aprovada pela Assembleia Americana o Tratado de União, Liga e Confederação Perpétua. Por essa razão, Meira Mattos afirma que diferente do monroísmo, o bolivarianísmo "não é unilateral, não sanciona nem aceita a predominância de um Estado, dando-lhe direitos de tutoria sobre os demais"222. A geoestratégia contra-hegemônica de Bolívar fica mais evidente no artigo $3^{\circ}$ do tratado, que dispõe:

\begin{abstract}
As partes contratantes se obrigam e comprometem a defender-se mutuamente de todo ataque que ponha em risco sua existência política, e empregar, contra os inimigos da independência de todas ou parte delas, toda a sua influência, recursos e forças marítimas e terrestres, segundo os contingentes com que cada um está obrigado, por convenção separada, desta referida data, a defender a sustentação da causa comum ${ }^{223}$.
\end{abstract}

Tal tratado constitui-se na criação da primeira instituição de segurança com vistas a assegurar a paz e a segurança internacional. Conforme o artigo $2^{\circ}$, que dispõe:

\begin{abstract}
O objetivo deste pacto perpétuo, será manter, em comum, defesas e ofensivas se for necessário, a soberania e independência de todos cada um dos Estados confederados da América contra toda dominação estrangeira, e se assegurar, desde agora, para sempre, a importância de uma paz inalterável, e promover, ao efeito, a melhor harmonia e boa inteligência entre os povos, cidadãos e temas, respectivamente, com as demais potências com quem deve-se manter ou iniciar relações amistosas ${ }^{224}$.
\end{abstract}

Embora o tratado não tenha entrado em vigor, visto que foi ratificado somente pela Grande Colômbia (Colômbia, Equador, Panamá e Venezuela de hoje), seus ideais e valores enunciados estabeleceram as bases jurídicas para as relações internacionais contemporâneas. Para Jesus Maria Yepes, o tratado trouxe inovações:

Manutenção da paz, segurança coletiva, defesa recíproca e mútua ajuda
contra o agressor, garantia da independência política e da integridade
territorial dos Estados-membros; solução pacífica de controvérsias

\footnotetext{
222 MATTOS, Carlos de Meira. Projeção Mundial do Brasil. In: MATTOS, Carlos de Meira. Geopolítica. Rio de Janeiro: Editora FGV, 2011, v. 1, p. 65.

223 TRATADO de União Liga e Confederação Perpétua, 1826. In: MENEZES, Wagner. A contribuição da América Latina para o Direito Internacional: o Princípio da Solidariedade. Tese de Doutorado apresentada ao Programa de Pós-Graduação em Integração da América Latina (PROLAM) da Universidade de São Paulo. São Paulo, 2007, p. 274-5.

${ }^{224}$ Ibidem, p. 274.
} 
internacionais, quais quer que sejam suas naturezas e origens, codificação do Direito Internacional ${ }^{225}$.

O Tratado de União, Liga e Confederação Perpétua, apresentado no Congresso do Panamá, em 1826, influenciou também na criação de organizações intergovernamentais, tanto é assim que seus dispositivos foram reproduzidos em textos dos tratados constitutivos da Liga das Nações, em 1919, e das Nações Unidas, em 1945, que permanecem até hoje para a sociedade internacional.

Nesse sentido, o professor José Carlos Brandi Aleixo aponta:

Os artigos II e XXI do Tratado do Panamá são antecedentes lógicos do artigo $\mathrm{X}$ da Liga das Nações, que trata da garantia da independência política e integridade territorial dos Estados. A respeito, o renomado internacionalista francês Albert de La Pradelle dizia que "o artigo X do Pacto da Sociedade das Nações não é mais do que a aplicação ao mundo inteiro das doutrinas de Simon Bolívar"226.

A título de exemplo, vale ressaltar outros pontos do Tratado do Panamá. Pelo artigo XVI, "as partes contratantes se obrigam, e se comprometem solenemente a transigir amigavelmente entre si todas as diferenças que existam ou possam existir entre elas [...]". Segundo Jesus Maria Yepes, é no Tratado do Panamá que se menciona pela primeira vez, na história das instituições internacionais, o sistema de conciliação para resolver os conflitos entre os Estados, a cargo da Assembleia Geral. O princípio de Consulta Mútua, que só é firmado na Conferência Interamericana para a Manutenção da Paz, realizada em Buenos Aires, em 1936, encontra-se claramente no artigo XIII do Tratado do Panamá ${ }^{227}$.

As Nações Unidas prestaram um tributo a Simon Bolívar, reconhecendo-o como um dos grandes expoentes na luta pela independência da América, tendo o seu nome homenageado numa placa no edifício Sede da organização como uma lembrança permanente a sua memória. De acordo com Wagner Menezes, com a independência dos países da América Latina ampliou consideravelmente a sociedade internacional; o Direito Internacional deixa de ser marcadamente eurocêntrico e, pela primeira vez na História, passa a contar com novos atores ${ }^{228}$.

\footnotetext{
225 YEPES, Jesus Maria. Del Congresso do Panamá a la Conferência de Caracas. Caracas: Oficina Central de Informação, 1976, p. 106.

${ }^{226}$ ALEIXO, José Carlos Brandi. O Brasil e o Congresso Anfictiônico do Panamá. Revista Brasileira de Política Internacional. Brasília: FUNAG, ano 43, n.2, 2000, p. 172.

${ }^{227}$ Ibidem, p. 172.

${ }^{228}$ MENEZES, Wagner. Op. cit., 2007, p. 90.
} 


\subsection{Arquitetura contemporânea de segurança regional}

Atualmente, um dos desdobramentos do monroísmo e do bolivarianismo na América Latina é uma arquitetura de segurança marcada pela presença de forças centrífugas e centrípetas na região. Para Milton Santos, as forças centrípetas são forças de agregação que dão coesão a uma base territorial específica, já as forças centrífugas são forças de desagregação que produzem tendência à fragmentação ${ }^{229}$.

Nesse sentido, o bolivarianismo é identificado como sendo uma força centrípeta pelo fato de ter influenciado na criação de instituições de segurança regionais como a União de Nações Sul-Americanas (UNASUL) e a Comunidade de Estados LatinoAmericanos e Caribenhos (CELAC). Mesmo com pouco tempo em funcionamento, essas instituições desempenham, politicamente, um papel relevante na solução pacífica de controvérsia, tendo atingido avanços importantes na mediação de tensões regionais a exemplo da crise separatista do Pando (Bolívia, 2008), do acordo EUA-Colômbia que visava ampliar as bases militares no território colombiano (2009), da crise entre Colômbia e Venezuela (2010), do apoio à ordem constitucional e democrática do Equador quando da sublevação de sua Polícia Nacional $(2010)^{230}$, de reconhecer o direito da Argentina sobre as Ilhas Malvinas (2014), de rejeitar o decreto dos Estados Unidos contra a Venezuela (2015) e do apoio ao processo de paz na Colômbia $(2016)^{231}$.

Todas essas ações demonstram a importância da UNASUL e da CELAC que atuam como forças centrípetas na arquitetura contemporânea de segurança da América Latina, respeitando os princípios e normas do Direito Internacional, portanto, corroborando a tese de que a região é uma "Zona de Paz"232. A seguir, apresentaremos cinco fatores que fundamentam essa ideia:

\footnotetext{
${ }^{229}$ SANTOS, Milton. A natureza do Espaço: Técnica e Tempo, Razão e Emoção. 4 ed. São Paulo: Editora da Universidade de São Paulo, 2014, p. 286; SANTOS, Milton. Op. cit., 2015, p. 110.

${ }^{230}$ UNASUL. Ministerio das Relações Exteriores. Disponível em: <http://www.itamaraty.gov.br/ptBR/politica-externa/integracao-regional/688-uniao-de-nacoes-sul-almericanas $>$. Acesso em: 2 ago. 2017.

231 Presidente Correa: Países miembros de Celac confirman su compromiso de integración. La Comunidad de Estados Latinoamericanos y Caribeños, ene. 28, 2016. Disponível em: $<$ https://celac.cancilleria.gob.ec/presidente-correa-paises-miembros-de-celac-confirman-sucompromiso-de-integracion/>. Acesso em: 14 jul. 2017.

${ }^{232}$ PERES, Bruno. Celac declara América Latina e Caribe como Zona de Paz. Valor Econômico, São Paulo, 29 jan. 2014. Disponível em: 〈http://www.valor.com.br/internacional/3412940/celac-declaraamerica-latina-e-caribe-como-zona-de-paz>. Acesso em: 26 jul. 2017.
} 
1) Pelo fato da América Latina, historicamente, ter sido subjugada pelo colonialismo, neocolonialismo e depois pelo imperialismo, formou-se na região uma consciência de respeito à soberania dos Estados. Por essa razão, em muitos casos de litígios fronteiriços, os países utilizaram o critério do uti possidetis como mecanismo de solução pacífica de controvérsias;

2) Há uma escola de pensamento jurídico (latino-americana) que está na vanguarda do Direito Internacional. Seus expoentes são dois argentinos Carlos Calvo e Luis Maria Drago, que elaboraram respectivamente a "Doutrina Calvo"233 e a "Doutrina Drago"234, e também o ministro das Relações Exteriores do Uruguai, Baltasar Blum, autor da "Doutrina Blum"235. A contribuição deles foi tão relevante que suas doutrinas foram incorporadas na Carta das Nações Unidas ${ }^{236}$ e da OEA ${ }^{237}$;

233 A Doutrina Calvo é uma doutrina latino-americana de direito internacional responsável por estabelecer que as pessoas que vivem em um país estrangeiro devem submeter suas reclamações e reivindicações à jurisdição local, evitando recorrer às pressões diplomáticas ou à intervenção militar de seu país de origem. Dessa forma, busca-se impedir que os países mais poderosos interfiram na jurisdição dos mais fracos (ARGENTINA. Ministerio de Defensa. Libro Blanco de La Defensa. Buenos Aires, 2010, p. 25).

234 A Doutrina Drago foi anunciada em 1902. Ela estabeleceu que nenhum país estrangeiro poderia utilizar a força intervindo contra uma nação americana para cobrar uma dívida, uma vez que os Estados são entidades de direito perfeitamente iguais entre si e mutuamente credores porque as mesmas considerações e respeito vale para eles [...] sem a limitação de seu direito primordial de entidade soberana (Ibidem, p. 25). O motivo de tal doutrina foi o bloqueio naval contra a Venezuela realizado pelas armadas do Reino Unido, Alemanha e Itália diante do não pagamento da elevada dívida externa acumulada pela Venezuela e cujo presidente, Cipriano Castro, se negava a pagar. Apesar de que a doutrina Monroe o exigia, os Estados Unidos se negaram a defender a Venezuela com o argumento de que não ajudaria em casos de não pagamento de dívida. Disponível em:

<http://cadtm.org/spip.php?page=imprimer\&id article=10700\#nb3 > Acesso em: 8 jun. 2015.

${ }^{235}$ A Doutrina Blum guarda relação com o Princípio de Solidariedade existente entre os Estados latinoamericanos e também invoca os laços de defesa comum continental diante de uma ameaça estrangeira, como continuidade aos preceitos bolivarianos. Em 12 de junho de 1917, o ministro das Relações Exteriores do Uruguai, Baltasar Blum, diante das repercussões da Primeira Guerra Mundial, emitiu nota da chancelaria invocando os laços de amizades entre os países da região no sentido de que todo ato frontalmente contrário aos princípios e regras do Direito Internacional, realizado contra os países da América, constituiria uma ofensa a todos, e, em função disso, provocaria em todos uma reação comum (MENEZES, Wagner. Derecho Internacional en América Latina. Brasília: FUNAG, 2010, p. 149-150).

${ }^{236}$ Ao buscar a solução pacífica de controvérsias, a ONU reconhece no seu artigo $2^{\circ}$, parágrafo $4^{\circ}$, a "Doutrina Drago" ao afirmar que: "Todos os membros deverão evitar em suas relações internacionais a ameaça ou o uso da força contra a integridade territorial ou a independência política de qualquer Estado". No artigo 51, reconhece o princípio de solidariedade postulado pela "Doutrina Blum" ao afirmar "o direito inerente de legítima defesa individual ou coletiva no caso de ocorrer um ataque armado contra um Membro das Nações Unidas."

${ }^{237}$ A Carta da OEA, em seus artigos 2, 19, 20, 21 e 22, consagra a "Doutrina Drago" ao afirmar o respeito ao princípio da não intervenção, a inviolabilidade territorial e a não recorrer ao uso da força. Ao enumerar os princípios em que se baseia, estabelece no artigo $2^{\circ}$, alínea "b", "Promover e consolidar a democracia representativa, respeitando o princípio da não intervenção". O artigo 19: "Nenhum Estado ou grupo de Estados tem o direito de intervir, direta ou indiretamente, seja qual for o motivo, nos assuntos internos ou 
3) Na América Latina há instituições de segurança como a OEA, UNASUL e CELAC, que contribuem para gerar informações que se traduzem em "medidas de confiança mútua", diminuindo o nível de incertezas entre os Estados;

4) A América Latina é uma região livre de armas nucleares. O Tratado de Tlatelolco, de 1967, contribuiu para a desnuclearização;

\author{
5) Embora a América Latina tenha uma história marcada por conflitos \\ interestatais $^{238}$, quando comparada com outros continentes, a região é
}

externos de qualquer outro. Este princípio exclui não somente a força armada, mas também qualquer outra forma de interferência ou tendência atentatória à personalidade do Estado e dos elementos políticos, econômicos e culturais que os constituem". O artigo 20 enuncia, por sua vez, que "Nenhum Estado poderá aplicar ou estimular medidas coercitivas de caráter econômico e político, para forçar a vontade soberana de outro Estado e obter deste vantagens de qualquer natureza". E ainda o artigo 21: "O território de um Estado é inviolável; não pode ser objeto de ocupação militar, nem de outras medidas de força tomadas por outro Estado, direta ou indiretamente, qualquer que seja o motivo, embora de maneira temporária. Não se reconhecerão as aquisições territoriais ou as vantagens especiais obtidas pela força ou por qualquer outro meio de coação". Por fim, o artigo 22: "Os Estados americanos se comprometem, em suas relações internacionais, a não recorrer ao uso da força, salvo em caso de legítima defesa, em conformidade com os tratados vigentes, ou em cumprimento dos mesmos tratados". Já a "Doutrina Calvo", foi adotada em várias constituições latino-americanas, tendo, inclusive, sido positivada no artigo $7^{\circ}$ do Pacto de Bogotá, resultante da XI Conferência Interamericana, de 1948. Tal artigo estabelece que "As altas partes contratantes comprometem-se a não fazer reclamações diplomáticas para proteger seus cidadãos, nem a iniciar a esse respeito uma controvérsia perante a jurisdição internacional, quando aqueles cidadãos tenham à sua disposição meios expedidos de recorrer aos tribunais domésticos competentes do Estado correspondente". E, por fim, a "Doutrina Blum", que inspirou o princípio da legítima defesa coletiva. Tal doutrina guarda relação com o princípio da solidariedade, inserida em 1947, no TIAR. Ao enunciar o princípio de solidariedade no seu preâmbulo, estabelece no artigo 3: "As altas Partes Contratantes concordam em que 'um ataque armado, por parte de qualquer Estado, contra um Estado americano, será considerado como um ataque contra todos os Estados Americanos,' e, em consequência, cada uma das ditas Partes Contratantes, se compromete a ajudar a fazer frente ao ataque, no exercício do direito iminente de legítima defesa individual ou coletiva que é reconhecido pelo artigo 51 da Carta das Nações Unidas." Em 1948, na Carta da OEA, estabeleceu no seu Tratado constitutivo o artigo $3^{\circ}$, alínea "h": "A agressão a um Estado americano constitui uma agressão a todos os demais Estados americanos" e também o artigo 28: "Toda agressão de um Estado contra a integridade ou a inviolabilidade do território, ou contra a soberania, ou a independência política de um Estado Americano, será considerada como um ato de agressão contra todos os Estados Americanos".

${ }^{238}$ Os conflitos interestatais na América Latina remontam desde o século XIX com a Guerra da Cisplatina no período de 1825 a 1828. Foi um conflito ocorrido entre o Império do Brasil e as Províncias Unidas do Rio da Prata, pela posse da Província Cisplatina, a região da atual República Oriental do Uruguai; a Guerra do Prata em 1851, entre Argentina e Brasil, pela influência no Uruguai e hegemonia na região do Rio da Prata; a Guerra do Uruguai, em 1864, que foi um conflito entre os partidos blanco e colorado para conquistar e se manter no poder no país com envolvimentos dos países vizinhos da região como Brasil e Argentina; a Guerra do Paraguai, de 1864 a 1870, confrontando o Paraguai e a Tríplice Aliança, composta pelo Brasil, Argentina e Uruguai, e a Guerra do Pacífico, em 1879, confrontando o Chile às forças conjuntas da Bolívia e do Peru. Ao final da guerra, o Chile anexou ricas áreas em recursos naturais de ambos os países derrotados e a Bolívia ainda perdeu a sua saída para o mar. Já entre as guerras no século XX figuram a Guerra do Chaco entre Bolívia e Paraguai, de 1932 a 1935, pela disputa territorial da região do Chaco Boreal, tendo como uma das causas a descoberta de petróleo no sopé dos Andes (o conflito acabou sem vencedores, com a região partilhada entre os dois países); a Guerra do Equador-Peru, entre 1941-1942, em que o exército do Peru invade o Equador e toma metade de seu território. A disputa 
considerada estável e pacífica, devido ao baixo índice de conflitos armados, conforme demonstra o gráfico 1 , a seguir.

\section{Gráfico 1: Total de conflitos armados por região (2006-2015)}

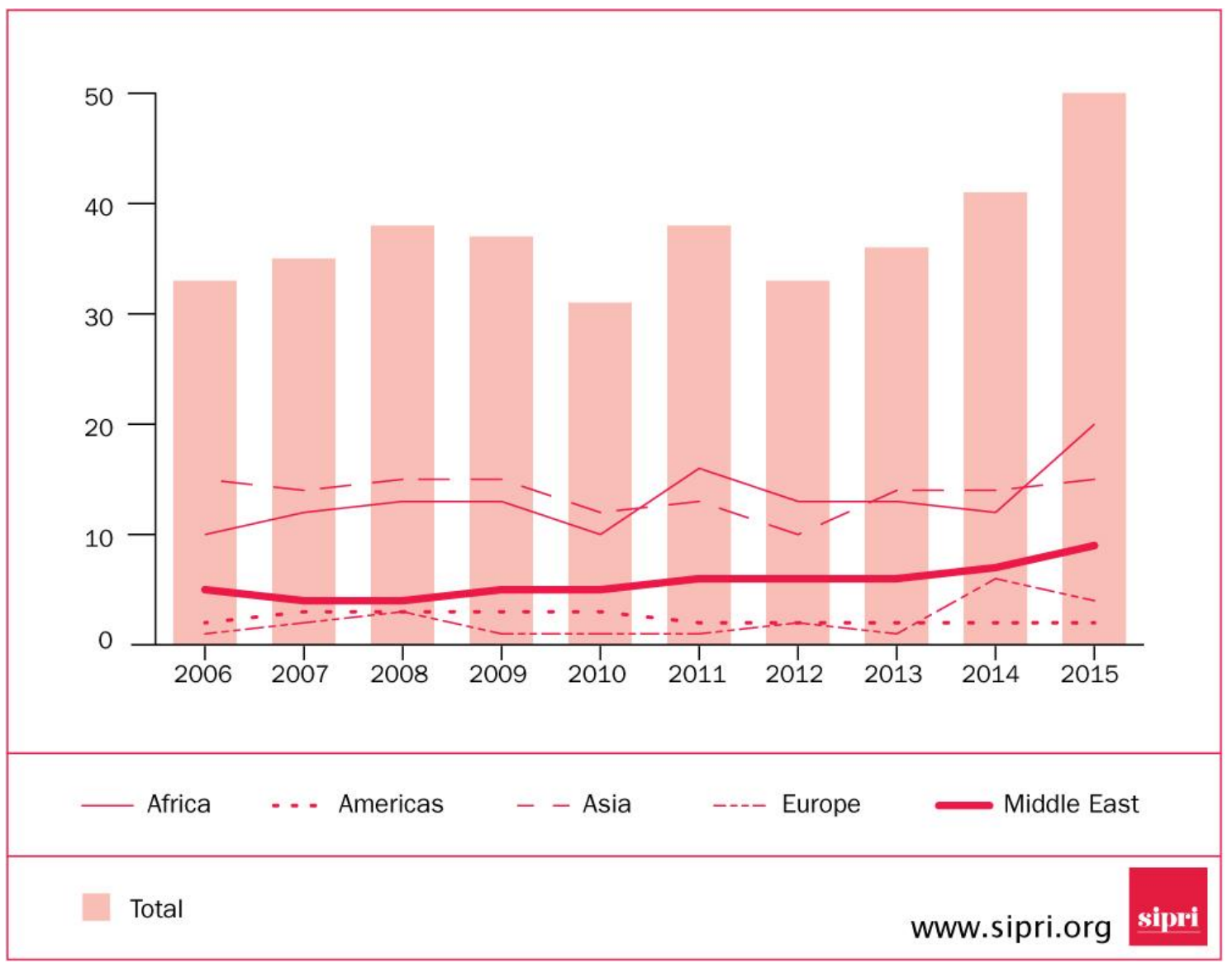

Apesar de a América Latina ser considerada, relativamente, uma zona de paz, devido ao baixo índice de conflitos armados, não significa que as questões de segurança estejam ausentes na agenda política dos países latino-americanos. Nem poderia ser diferente, sobretudo porque há forças centrífugas presentes na região que visam a sua fragmentação para impedir o processo de integração regional.

é resolvida um ano depois com a assinatura, no Rio de Janeiro, do Tratado de Paz, Amizade e Cooperação conhecido como "Protocolo do Rio". Mas a tensão na fronteira entre os dois países permanece até hoje; a Guerra do Futebol entre El Salvador e Honduras, em 1969, que durou 4 dias ou 100 horas; o conflito de Beagle, em 1971, quando a Argentina e o Chile designaram a rainha britânica Elizabeth II para arbitrar a disputa pela posse do Estreito de Beagle, na região da Terra do Fogo, extremo sul do continente americano. Em 1978, a rainha concedeu a posse de Beagle ao Chile, o que na prática garantiria ao Chile uma saída para o Oceano Atlântico. A Argentina discordou da decisão. Tropas de ambos os lados chegaram a serem mobilizadas para uma guerra, mas o papa João Paulo II interveio e impediu o derramamento de sangue. E, por fim, a última guerra interestatal, no século XX, foi a Guerra do Cenepa entre Equador e Peru, em 1995. Esse foi um conflito armado que opôs as forças armadas de ambos os países que lutaram pelo controle de uma área disputada na fronteira. 
Ao contrário do que afirmavam alguns especialistas em política e a mídia cartelizada, que depois da Queda do muro de Berlim, em 1989, o mundo estava entrando numa "nova era", em que a cooperação internacional ocuparia o lugar dos conflitos armados, não foi isso que aconteceu ${ }^{239}$. A primeira Guerra do Golfo Pérsico, em 1991, contra Saddam Hussein, não só desmente essa tese, como também inaugura, inequivocamente, agora sim, uma nova "Ordem Mundial"240. Segundo André Martin, surgiu um novo cenário geopolítico, marcado por uma tentativa de recolonização do Hemisfério Sul pelas grandes potências do Hemisfério Norte, capitaneadas pelos Estados Unidos e a Organização do Tratado do Atlântico Norte (OTAN), que sob o pretexto de intervenções humanitárias, o que estão fazendo, na verdade, é ocupar áreas no Hemisfério Sul onde coincidem recursos naturais estratégicos. Depois desse episódio, vieram muitos outros, os americanos se envolveram na guerra civil da Somália, na Iugoslávia, o segundo envolvimento no Iraque, no Afeganistão, na Líbia, no Mali e atualmente na Síria ${ }^{241}$.

Esse intervencionismo contemporâneo traz a ideia do Destino Manifesto e do monroísmo que são identificados como forças centrífugas na América Latina, pelo fato de ser uma política externa unilateral dos Estados Unidos na região e que, a rigor, ainda continua, desta vez, está expresso no projeto monopolar do país, que busca impor ao mundo uma ideologia baseada em um único modelo de sociedade e economia, fundamentalmente alicerçado no seu poderio militar colossal.

O Pentágono regionalizou o seu poderio militar em escala planetária, em seis unidades de comandos regionais, cada uma delas compreende uma área geográfica: i) $\mathrm{O}$ Comando Norte (NORTHCOM) abrange os Estados Unidos incluindo o Alasca, o Canadá, o México e as águas circundantes até aproximadamente 500 milhas náuticas. Também inclui o Golfo do México, o Estreito da Flórida, e no Caribe inclui Bahamas,

\footnotetext{
${ }^{239}$ MARTIN, André Roberto. O Brasil procura seu lugar no mundo. In: SCARLATO, Francisco Capurano et al (Org.). O novo mapa do mundo: globalização e espaço latino-americano. 4. ed. São Paulo: Hucitec, 2002, p. 106.

${ }^{240}$ Utilizamos a ideia de "Ordem Mundial" definida conceitualmente pelo Prof. Dr. André Martin. Segundo ele, o termo refere-se ao "comportamento habitual das grandes potências". Desse modo, somente quando uma grande potência se comporta de forma "não habitual" é que poderá revelar uma nova tendência, isto é, uma Nova Ordem Mundial. A título de exemplo, a saída dos Estados Unidos da Parceria Transpacífico (TPP) e o Brexit são comportamentos que ninguém esperava, sobretudo porque são os principais defensores do globalismo. Isso sim revela uma temdência para uma Nova Ordem Mundial pós-Globalização.

${ }^{241}$ Palestra de Encerramento do Prof. Dr. André Martin no $3^{\circ}$ Simpósio Nacional de Geografia Política. Manaus, 07 a 10 de maio de 2013. Disponível em: <https://www.youtube.com/watch?v=Dm8cVCtbObQ>. Acesso em: 03 nov. 2016.
} 
Porto Rico e as Ilhas Virgens dos Estados Unidos ${ }^{242}$; ii) O Comando Sul (SOUTHCOM) inclui a América Latina a partir do sul do México, as águas adjacentes à América Central e do Sul e o Mar do Caribe ${ }^{243}$; iii) O Comando Europeu (EUCOM) abrange a Europa incluindo toda a Rússia, a costa leste do Mediterrâneo, conhecida como Levante que abrange o Chipre e Israel, e o sudoeste da Ásia que compreende a Turquia, Armênia, Azerbaijão e Geórgia ${ }^{244}$; iv) O Comando da África (AFRICOM) compreende o continente africano, exceto o Egito ${ }^{245}$; v) O Comando Central (CENTCOM) abrange 20 nações do Oriente Médio, incluindo também o Egito, Ásia Central e do Sul e os cursos de água estratégicos que os rodeiam ${ }^{246}$; vi) O Comando do Pacífico (PACOM) que inclui 36 nações que compõem a região Ásia-Pacífico ${ }^{247}$, desde o extremo oriente, a Ásia meridional, o sudeste asiático até a Oceania.

\footnotetext{
242 Área de responsabilidade do Comando Norte dos Estados Unidos. Disponível em: <http://www.northcom.mil/About-USNORTHCOM/>. Acesso em: 6 maio 2017.

243 Área de responsabilidade do Comando Sul dos Estados Unidos. Disponível em: <http://www.southcom.mil/About/Area-of-Responsibility/>. Acesso em: 6 maio 2017.

244 Área de responsabilidade do Comando Europeu dos Estados Unidos. Disponível em: <http://www.eucom.mil/about/the-region>. Acesso em: 6 maio 2017.

${ }^{245}$ Área de responsabilidade do Comando da África dos Estados Unidos. Disponível em: $<$ http://www.africom.mil/area-of-responsibility>. Acesso em: 6 maio 2017.

246 Área de responsabilidade do Comando Central dos Estados Unidos. Disponível em: <http://www.centcom.mil/ABOUT-US/COMPONENT-COMMANDS/>. Acesso em: 6 maio 2017.

${ }^{247}$ Área de responsabilidade do Comando do Pacífico dos Estados Unidos. Disponível em: $\langle$ http://www.pacom.mil/About-USPACOM/USPACOM-Area-of-Responsibility/l. Acesso em: 6 maio 2017.
} 


\section{Mapa 17: O Projeto Monopolar dos Estados Unidos}

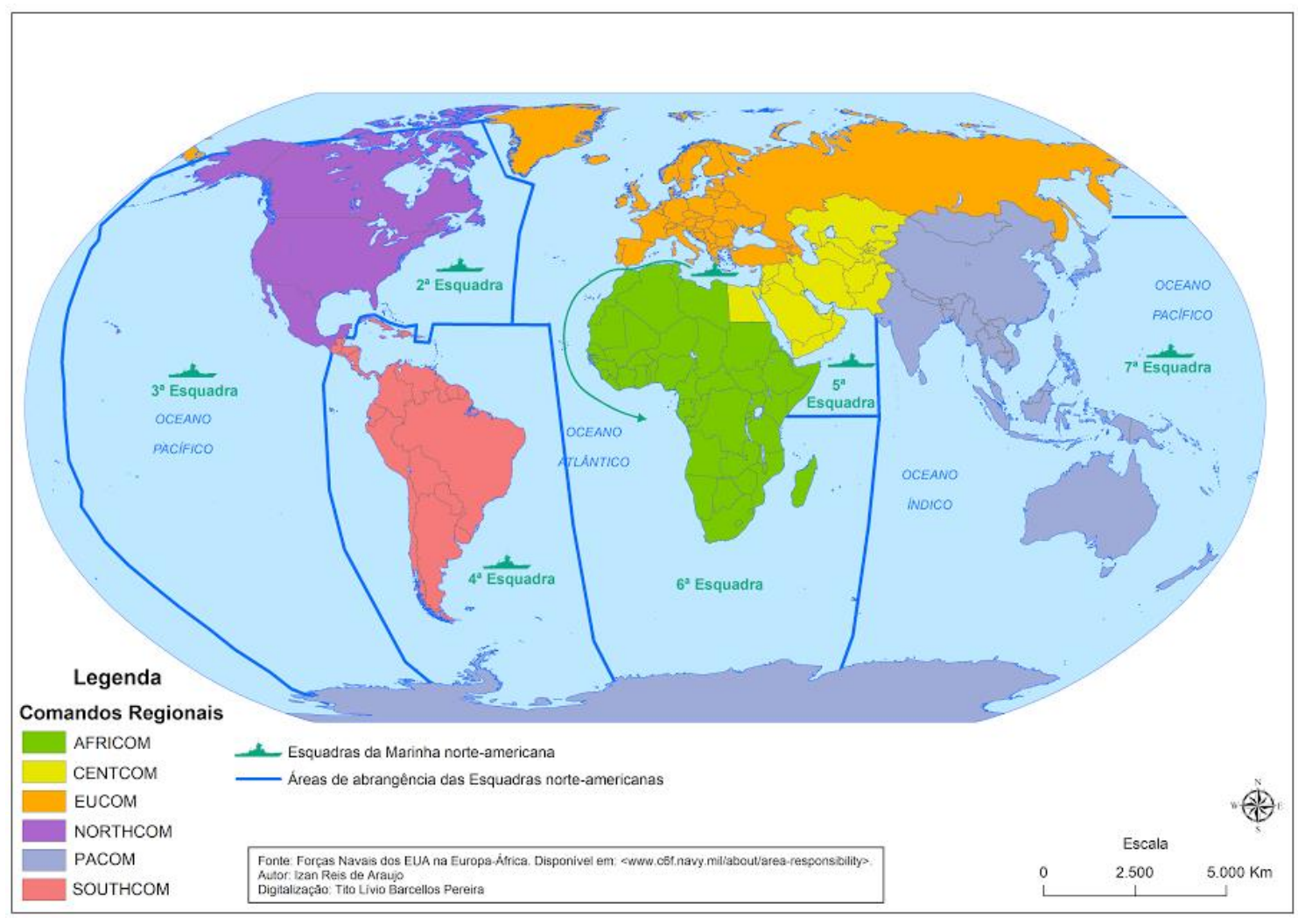

O mapa acima mostra que cada uma das esquadras está na jurisdição de uma determinada Unidade de Comando Regional, com exceção do Comando da África que não possui nenhuma esquadra na sua área de responsabilidade. Por essa razão, a Sexta Esquadra que está vinculada, operacionalmente, ao EUCOM - abrange aproximadamente metade do Oceano Atlântico, do Ártico à Antártida, bem como os mares Barents, Báltico, do Norte, Mediterrâneo, Adriático, Negro e Cáspio - atua também numa parte significativa do continente africano ${ }^{248}$. Já a Segunda Esquadra está vinculada ao NORTHCOM; a Terceira e a Sétima Esquadras estão na jurisdição do PACOM; A Quinta Esquadra opera na área de responsabilidade do CENTCOM e, finalmente, no SOUTHCOM, a Quarta Esquadra está operando.

Além das esquadras, essas unidades de comandos regionais contam também com bases militares espalhadas na sua área de responsabilidade. Com esse poderio aeronaval colossal, os Estados Unidos estão prontos para intervir em qualquer país, se for

${ }^{248}$ U.S. Naval Forces Europe-Africa/ U.S. 6th Fleet. Disponível em:

〈http://www.c6f.navy.mil/about/area-responsibility>. Acesso em: 17 mar. 2017. 
necessário. A atuação da Quinta Esquadra, nas intervenções no Afeganistão, em 2001, e no Iraque, em 2003, corrobora essa tese ${ }^{249}$.

Dentre os Comandos Regionais, o Comando Sul é o mais antigo, existe desde 1941, na época era chamado de Comando de Defesa do Caribe, desmentindo a tese de que América Latina não é uma prioridade na agenda dos Estados Unidos como dizem alguns especialistas e a mídia cartelizada ${ }^{250}$. Outro exemplo de que a região é importante na estratégia global de Washington foi o próprio Tratado Interamericano de Assistência Recíproca (TIAR), que surgiu em 1947, dois anos antes da criação da OTAN. Por fim, o Tratado de Tlatelolco foi celebrado em 1967, enquanto que o Tratado de Não Proliferação Nuclear (TNP) foi assinado apenas no ano seguinte. Diante disso, a pergunta certa a se fazer é o porquê da prioridade na região?

Ao analisar a América Latina à luz da geografia política, identificam-se o "espaço" e a "posição" como dois conceitos significativos que juntos não só valorizam essa região, mas também podem mudar a percepção das pessoas sobre o papel da América Latina nas relações internacionais. O seu "espaço" geográfico é rico em recursos naturais indispensáveis para uma sociedade que, no caso latino-americano, ainda apresenta uma demografia pujante, além disso, a sua "posição" geográfica lhe confere uma importância geoestratégica. Tanto isto é certo que a abertura do canal do Panamá, em 1914, possibilitou que os Estados Unidos dessem o sentido de ilha continente ao país, fazendo a articulação do seu litoral, do Atlântico ao Pacífico, conforme apontava Mahan, sem precisar das longas circum-navegações em torno do cabo Horn na porção meridional da América do Sul. O próprio Pentágono revelou que a América Latina “ocupou um lugar central na estratégia global dos Estados Unidos durante todo o século XX"251.

É por isso mesmo que, nos últimos anos, especialmente depois da crise econômica mundial, em 2008, os Estados Unidos têm aumentado a sua ingerência na região para não perder a sua zona de influência para os chineses que estão presentes na

\footnotetext{
${ }^{249}$ US. Naval Forces Central Command and Fith Fleet. Disponível em:

<http://web.archive.org/web/20070205012103/http://www.cusnc.navy.mil/history/index.html >. Acesso em 17 mar. 2017.

${ }^{250}$ ROSSI, Clóvis. América Latina volta à "irrelevância". Folha de S. Paulo. São Paulo, 23 set. 2001. Disponível em: 〈http://www1.folha.uol.com.br/fsp/especial/fj2309200112.htm〉. Acesso em: 21 out. 2015.

${ }^{251}$ Documento oficial do governo dos Estados Unidos afirma que a América Latina foi prioridade na agenda da política externa do país em todo o século XX (U.S. SOUTHER COMMAND, a Pictorial History, s.d. p, 6. Disponível em: 〈http://www.southcom.mil/50/Pages/Main.aspx $>$. Acesso em 8 jan. 2016.
} 
América Latina, especialmente através do bloco geopolítico formado pelo Brasil, Rússia, Índia, China e África do Sul (BRICS). Moniz Bandeira descreve o intervencionismo americano como uma "geopolítica do cerco" ao Brasil e seu projeto de integração regional sul-americano ${ }^{252}$. Essa hipótese se confirmava empiricamente nas três frentes geoestratégicas do Pentágono na América do Sul: o Cone Sul, o Atlântico Sul e a região andina.

$\mathrm{Na}$ primeira frente geoestratégica, localizada no Cone Sul, os americanos estabeleceram uma base militar no território paraguaio ${ }^{253}$ sob o pretexto de que grupos terroristas estariam utilizando a Tríplice Fronteira como fonte de captação de recursos para financiar grupos radicais islamitas, tais como Hezballah e Hamas. Assim, afirma Carlos Mele:

\begin{abstract}
Os Estados Unidos - os primeiros a reconhecerem o novo governo do Paraguai pós-Lugo - têm interesse na manutenção de sua hegemonia na região, em detrimento de uma integração latino-americana. O estabelecimento da suposta base permitiria maior proximidade com os países sul-americanos e respostas imediatas na hipótese de confrontos, devido a sua localização geográfica estratégica. Também permite o acesso americano ao Aquífero Guarani, uma das maiores reservas de água potável do mundo, e facilita as ações de órgãos de segurança dos Estados Unidos - como o Departamento Federal de Investigação (FBI) e a Agência Central de Inteligência (CIA) - na área da tríplice fronteira, apontada pelos militares ianques como reduto de células terroristas do Hezbollah, do Hamas e da AlQaeda ${ }^{254}$.
\end{abstract}

Na segunda frente do Pentágono, sob a alegação de combater a pirataria que ameaça o fluxo do livre comércio no mar do Caribe e no Atlântico Sul, os Estados Unidos reativaram a Quarta Esquadra, em 2008 e, nesse mesmo ano, criaram o

252 MONIZ BANDEIRA, Luiz Alberto. A Geopolítica do Cerco. Defesanet. Brasília, 17 fev. 2015. Disponível em: <http://www.defesanet.com.br/pensamento/noticia/18221/Geopolitica-do-Cerco----Tesede-Moniz-Bandeira-/>. Acesso em: 17 jun. 2016.

${ }^{253}$ A base militar no Paraguai, muito próxima a Itaipu, é uma espécie de reserva estratégica: possui pista de pouso que permite a operação de aviões do porte dos B-52 e Galaxys e instalações que podem abrigar 16 mil soldados nas proximidades da fronteira entre Brasil, Argentina e Bolívia. O Congresso paraguaio autorizou, em junho de 2005, a livre circulação de tropas norte-americanas e concedeu-lhes imunidade penal. Isso significa que, qualquer que seja o ato praticado pelos soldados dos EUA no Paraguai, eles não poderão ser julgados pelas côrtes do país. O objetivo de Washington era obter as mesmas regalias nas demais nações do Cone Sul, mas a resistência do Brasil e da Argentina impediu que isso acontecesse. Disponível em: 〈www.diplomatique.or.br/print.php?tipo=ar\&id=200〉. Acesso em 17 dez. 2014.

254 OHARA, Carlos. Presença de militares dos EUA levanta suspeita no Paraguai. Terra, Assunção, 25 ago. 2012. Disponível em: <http://noticias.terra.com.br/mundo/presenca-de-militares-dos-eua-levantasuspeitas-no-paraguai,acea9c01358da310VgnCLD200000bbcceb0aRCRD.html>. Acesso em 14 jan. 2015. 
Comando da África, mas, paradoxalmente, não ratificaram ${ }^{255}$ a Convenção das Nações Unidas sobre o Direito do Mar que já aborda a questão da pirataria. Para Moniz Bandeira, "as reservas descobertas na camada pré-sal inseriram o Brasil no mapa geopolítico do petróleo, levando o presidente George W. Bush a restaurar a Quarta Frota para o Atlântico Sul"256.

Referente à terceira frente, na região andina, o geógrafo brasileiro Wanderley Messias destaca que:

A implantação mais recente de bases militares em território colombiano (Plano Colômbia). A pretexto de apoio a esse país no combate ao narcotráfico e às Farc passou a dispor de poderoso aparato militar, sobretudo o aéreo, cujo poder de ataque alcança agora a escala da América do Sul Setentrional, incluindo o Caribe Meridional e a borda noroeste do Atlântico $\mathrm{Sul}^{257}$.

A presença militar norte-americana no território colombiano e também paraguaio fundamenta-se na classificação de "Estados frágeis" ${ }^{258}$. Isso implicou no aumento de capacidade desses Estados, alterando a arquitetura de segurança da América do Sul, trazendo à tona tensões fronteiriças que remetem ao conceito de "dilema de segurança", elaborado por John Herz, para designar que o acréscimo das capacidades militares de um Estado não gera segurança, mas sim insegurança aos demais Estados, pois eles percebem esse acréscimo da capacidade de seus vizinhos como ameaça e consequentemente aumentam seus investimentos em defesa.

Nas palavras de Herz:

A existência de um sistema internacional anárquico leva inevitavelmente a um "dilema de segurança". Grupos ou indivíduos vivendo em um ambiente dessa natureza têm preocupações em serem atacados, subjugados, dominados ou aniquilados por outros grupos ou outros indivíduos. Desse modo, os

\footnotetext{
${ }^{255}$ EUA querem ratificar convenção sobre mares de 1982. GGN, 24 maio 2012. Disponível em: $<$ http://jornalggn.com.br/blog/luisnassif/eua-querem-ratificar-convencao-sobre-mares-de-1982>. Acesso em: 4 jul. 2017.

${ }^{256}$ MONIZ BANDEIRA, Luiz Alberto. A Importância Geopolítica da América do Sul na Estratégia dos Estados Unidos. Revista da Escola Superior de Guerra, v. 14, p. 28, 2008.

${ }^{257}$ COSTA, Wanderley Messias da. Projeção do Brasil no Atlântico Sul: Geopolítica e Estratégia. Revista USP, São Paulo, n. 95, p. 18-9, 2012.

${ }^{258} \mathrm{Na}$ percepção de Washington, os "Estados frágeis" representam uma ameaça para a comunidade internacional porque são vulneráveis ao terrorismo, apresentam instituições fracas e não controlam seu território. A Estratégia Nacional de Combate ao Terrorismo concentra-se em "identificar e neutralizar ameaças antes que elas atinjam as nossas fronteiras" (WHITE HOUSE. National Strategy for Combating Terrorism. Washington D.C., 2003, p. 2). Desse modo, em nome da "paz e segurança internacional" esses "Estados frágeis" devem sofrer intervenção americana sem passar por nenhuma consulta das organizações internacionais.
} 
Estados, esforçando-se para alcançar a segurança de tal ataque, são levados a adquirir mais e mais poder, a fim de escapar do impacto do poder de outros. Isso, por sua vez, leva os outros Estados a sentirem-se mais inseguros e os obriga a se preparar para o pior. Uma vez que nenhum deles pode se sentir totalmente seguro, essa situação torna-se um círculo vicioso de segurança e aumento de capacidade ${ }^{259}$.

O conceito de "dilema de segurança" ficou evidente, especialmente depois da utilização da base militar de Palanquero, na Colômbia pelos Estados Unidos e sua ampliação para sete bases militares no país, em 2009. O aumento de capacidade do país vizinho levou o presidente Hugo Chávez a responder, enviando 15 mil soldados para a fronteira em novembro do mesmo ano. Nesse sentido, vale recordar Moniz Bandeira quando afirma que "[...] o temor de Chávez é que não querendo ou não podendo atacar diretamente a Venezuela, os Estados Unidos tratem de forjar um incidente na fronteira com a Colômbia, de modo a provocar um conflito. Seu armamentismo é meramente defensivo" $" 260$.

No livro intitulado Imperialismo, estágio superior do capitalismo, publicado 1917, Lenin já apontava para a tentativa de recolonização das grandes potências centrais, que partilharam o mundo entre as associações de monopolistas capitalistas:

\begin{abstract}
As associações de monopolistas capitalistas - cartéis, sindicatos, trustes partilham entre si, em primeiro lugar, o mercado interno, apoderando-se mais ou menos completamente da produção do país. Mas, sob o capitalismo, o mercado interno está inevitavelmente vinculado ao externo. Há muito que o capitalismo criou um mercado mundial. E, à medida que aumentava a exportação de capitais e se ampliavam, sob todas as formas, as relações com o estrangeiro e com as colônias, assim, como as "esferas de influência" das maiores associações monopolistas, a marcha "natural" das coisas levou a um acordo universal entre elas, à constituição de cartéis internacionais ${ }^{261}$.
\end{abstract}

Desse modo, 31\% das maiores transnacionais do mundo são dos Estados Unidos $^{262}$. Essas empresas estão presentes em diversos ramos da economia, desde o setor automobilístico, informática, eletroeletrônica, aeroespacial, até o petróleo. Contudo, o monopólio do petróleo no mercado latino-americano está ameaçado por

\footnotetext{
${ }^{259}$ HERZ, John. "Idealist Internationalism and the Security Dilemma". World Politics, v. 2, n. 2, p. 157, 1950.

${ }^{260}$ MONIZ BANDEIRA, Luiz Alberto. Seria difícil para Chávez sustentar qualquer guerra. A tarde, Bahia, 8 jul. 2007. Entrevista.

${ }^{261}$ LENIN, Vladimir Llitch. Op. cit., 2012, p. 99.

${ }^{262}$ OLIVEIRA, Ariovaldo Umbelino de. A Mundialização do Capitalismo e a Geopolítica mundial no Fim do Século XX. In: ROSS, Jurandyr Luciano Sanches. (Org.).Geografia do Brasil. 6. ed. São Paulo: EDUSP, 2011, p. 253.
} 
duas empresas estatais que não estão vinculadas a essas grandes associações capitalistas: a brasileira Petrobras e a venezuelana PDVSA.

De acordo com o cientista político brasileiro André Neves, o petróleo desempenha um papel central para os Estados Unidos, tanto para a robustez da sua economia quanto para a operacionalidade de seu poderio militar:

\begin{abstract}
Além do aspecto econômico, o petróleo também desempenha um papel decisivo para a segurança nacional, pois o aparato militar americano - que inclui navios, aviões, helicópteros, carros de combate e transporte de tropas depende da energia fornecida pelos diversos derivados do petróleo. A dependência da energia fóssil cresce na medida em que as reservas próprias escasseiam, gerando dependência a fornecedores externos ${ }^{263}$.
\end{abstract}

Os dados a seguir (gráfico 2), publicados pela Organização dos Países Exportadores de Petróleo (OPEP), apontam que a Venezuela possui as maiores reservas de petróleo bruto do mundo, com depósitos totalizando 302,25 bilhões de barris. Suas receitas de petróleo representam cerca de $95 \%$ do total da exportação do país. Além do petróleo, os recursos naturais da Venezuela incluem: gás natural, minério de ferro, ouro, bauxita, diamantes e outros minerais.

${ }^{263}$ NEVES, André Luiz Varella. Governo George Walker Bush (2001-2004): Uma análise geopolítica das Guerras do Afeganistão e do Iraque. Tese de Doutorado apresentada ao Departamento de Ciência Política da Faculdade de Filosofia, Letras e Ciências Humanas da Universidade de São Paulo. São Paulo, 2010, p. 143. 
Gráfico 2: Participação da OPEP nas reservas mundiais de petróleo bruto (2016)

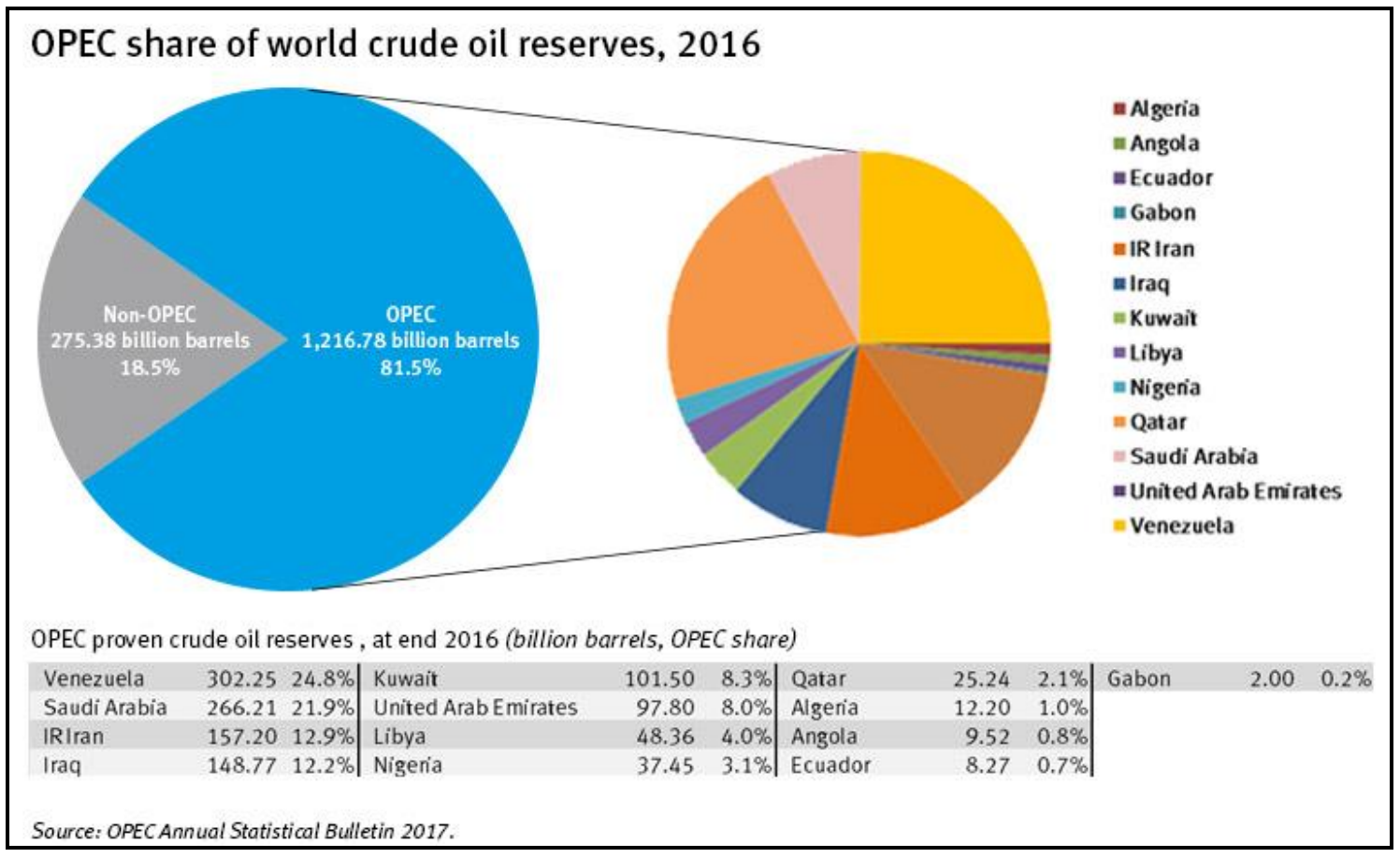

Em função dos recursos naturais estratégicos da América Latina, em especial o petróleo da Venezuela, os Estados Unidos continuarão se expandindo militarmente no subcontinente para assegurar que seus interesses comerciais e econômicos não sejam ameaçados, especialmente no Caribe que é a sua zona de presença imediata. Ainda nessa linha, em 2010, um documento secreto do Departamento de Estado Americano, vazado pelo site WikiLeaks, incluiu as minas brasileiras de nióbio na lista de locais cujos recursos naturais são consideradas estratégicos e imprescindíveis aos Estados Unidos $^{264}$.

Cabe destacar também que embora os recursos naturais despertem uma cobiça internacional, não podemos deixar de lembrar que Ratzel tinha razão ao ensinar que para a geografia política as categorias "espaço" e "posição" são igualmente relevantes para a valorização do território. O espaço revela a importância geoeconômica de um Estado, em decorrência dos seus recursos naturais, e a posição identifica a situação geoestratégica do território. Como exemplo de posição geográfica, temos as Malvinas, no Atlântico Sul, e também a base militar de Guantánamo, Cuba, localizada

${ }^{264}$ ALVARENGA, Darlan. Monopólio brasileiro do nióbio gera cobiça mundial, controvérsia e mitos. G1, São Paulo, 9 abr. 2013. Disponível em: <http://g1.globo.com/economia/negocios/noticia/2013/04/monopolio-brasileiro-do-niobio-gera-cobicamundial-controversia-e-mitos.html >. Acesso em: 9 maio 2016. 
geoestrategicamente no Caribe, em frente ao Golfo do México, que é a primeira linha de defesa dos Estados Unidos. Nesses dois casos, há uma cobiça nesses territórios em função de sua posição geográfica estratégica e não necessariamente em recursos naturais.

De acordo com o Embaixador Samuel Pinheiro Guimarães, para que o Brasil e a América do Sul "possam ser capazes de defender efetivamente seus interesses de longo prazo em um mundo instável, violento e arbitrário, é indispensável trabalhar de forma consistente e persistente em favor da emergência de um sistema mundial multipolar"265. Porque somente "a luta pela multipolaridade amplia, para o Brasil, o leque de possibilidades de construção de alianças específicas com o objetivo de reduzir os efeitos da concentração de poder que aumenta cotidianamente o fosso entre Estados"266.

\subsection{Instituições de Segurança}

Em uma sociedade internacional anárquica, em que as percepções de ameaças tradicionais e novas ameaças são iminentes, surgem as instituições de segurança que geram informações que se traduzem em confiança mútua, diminuindo o nível de incerteza entre os Estados. As primeiras ideias sobre a construção de instituições regionais na América Latina surgiram em 1815, com Simon Bolívar, ao escrever na famosa Carta da Jamaica "sobre sua esperança pela integração dos países latinoamericanos, que lutavam na época por sua independência definitiva da Espanha"267.

Essas instituições de segurança estão presentes em três níveis de análise: em escala mundial, regional e sub-regional. Na escala mundial, estão o Conselho de Segurança da ONU e a Corte Internacional de Justiça (CIJ), em Haia, que na qualidade de principal órgão jurídico das Nações Unidas tem contribuído na resolução pacífica de litígios sobre fronteiras nacionais. O caso mais recente foi quando o tribunal concedeu ao Peru parte do mar sob o controle do Chile, encerrando, assim, um dos litígios

\footnotetext{
265 GUIMARÃES, Samuel Pinheiro. Desafios brasileiros na era de gigantes. Rio de Janeiro: Contraponto, 2005, p. 275.

${ }^{266}$ GUIMARÃES, Samuel Pinheiro. Quinhentos anos de periferia: uma contribuição ao estudo da política internacional. 3. ed. Rio de Janeiro: Contraponto, 2001, p. 152.

${ }^{267}$ DOMINGUEZ, Jorge. "International cooperation in Latin America: the design of regional institutions by slow accretion". In: AMITAV, Acharya; ALASTAIR, Iain Johnston. (Org.). Crafting Cooperation: Regional International Institutions in Comparative Perspective. New York, Cambridge University Press, 2007, p. 85.
} 
territoriais mais antigos do continente ${ }^{268}$. Outra instituição de segurança, um tanto controversa nessa escala de análise, é a OTAN, pois muito embora a maioria dos países signatários seja da Europa, ainda há membros de outros dois continentes: América (Canadá e Estados Unidos) e Ásia (Turquia). Paradoxalmente, mesmo com o final da Guerra Fria, em 1991, onde não há mais a ameaça da aliança militar do bloco socialista capitaneada pelo Pacto de Varsóvia, a OTAN vem buscando o seu alargamento em direção ao leste europeu. Em 2014, a organização convidou a Ucrânia a entrar na aliança atlântica, mas o país preferiu se integrar no espaço geoeconômico russo proposto por Vladimir Putin, o que implicou numa crise colossal envolvendo a Rússia e o Ocidente cujos desdobramentos estamos presenciando na atualidade.

$\mathrm{Na}$ escala regional, figura a OEA como uma instituição de segurança que foi criada, em 1948, a partir da Carta de Bogotá, para centralizar o sistema interamericano $^{269}$. Suas iniciativas têm contribuído para as Medidas de Confiança Mútua (MCM). Segundo Francisco Aravena, essas medidas "são ações bilaterais e multilaterais para prevenir crises e conflitos. Ajudam na comunicação entre os atores. Criam uma atmosfera propícia para estabelecer um quadro de entendimento"270. A OEA, através de seu Conselho Permanente e da Comissão de Segurança Hemisférica, tem cooperado como fórum intergovernamental com algumas medidas de confiança na área de segurança, promovendo, por exemplo, a Conferência Ministerial de Defesa entre os ministros de Defesa e seus membros. Para Michele Bachelet, "só o fato de que entrem em contato direto os ministros da defesa de uma região, cuja história se caracterizou até pouco tempo por um número significativo de conflitos interestatais é, por si só, uma grande fonte de confiança a nível hemisférico"271.

\footnotetext{
${ }^{268}$ Tribunal concede ao Peru parte do mar sob controle do Chile. G1, São Paulo, 11 jan. 2014. Disponível em: <http://g1.globo.com/mundo/noticia/2014/01/tribunal-concede-ao-peru-parte-do-mar-sob-controledo-chile.html $>$. Acesso em: 30 out. 2014.

${ }^{269} \mathrm{O}$ marco doutrinário do surgimento do Sistema Interamericano foi em 1889 , quando ocorreu a Primeira Conferência Pan-americana, reunida na cidade de Washington [...]. Foi naquele momento que doutrinariamente se cunhou o termo pan-amercanismo para expressar um movimento de coesão continental resgatando suas raízes nos dois acontecimentos históricos tendo como referência tanto o bolivarianismo hispânico ou o monroísmo norte-americano. Por sistema interamericano é chamado o conjunto de instituições e regras que compõem a estrutura de representação dos Estados e está assentado sobre a OEA (MENEZES, Wagner. Op. cit., 2007, p. 79-80).

${ }^{270}$ ARAVENA, Francisco Rojas. Las Medidas de Confianza Mutua y de Seguridad: perspectivas desde Chile. Fasoc, v. 17, n. 1 - n. 2, p. 33, enero/junio, 2002.

${ }^{271}$ ORGANIZAÇÃO DOS ESTADOS AMERICANOS (OEA). Relatório da Presidência da Quinta Conferência de Ministros da Defesa das Américas. Washington, D.C., 2003, p. 2.
} 
Todavia, a instituição tem perdido influência nos países latino-americanos por dois fatores: primeiro porque essa organização tem se demonstrado ineficaz na resolução de alguns problemas, como no caso da Guerra das Malvinas, em 1982, quando o TIAR foi desrespeitado pelos Estados Unidos, uma vez que seu artigo 3 estabelece: “[...] um ataque armado, por parte de qualquer Estado, contra um Estado Americano, será considerado como um ataque contra todos os Estados Americanos [...]”. À época, o TIAR foi evocado pela Argentina, mas os Estados Unidos não ajudaram. Paradoxalmente, o governo americano, não satisfeito, ainda prestou apoio logístico aos ingleses contra a Argentina. Em segundo lugar, a cientista política Brigitte Weiffen afirma que durante a Guerra Fria, na América Latina, a OEA “foi percebida como um instrumento a partir do qual opera os Estados Unidos para fazer valer seus interesses hegemônicos"272.

Ainda na escala regional, outra instituição de segurança que surgiu mais recentemente foi a CELAC, criada em fevereiro de 2010, durante a Cúpula da Unidade da América Latina e do Caribe, realizada em Riviera Maya, México. A organização foi fundada como contraponto à OEA que excluiu Cuba do seu quadro de sócios enquanto que a CELAC reúne 33 países latino-americanos, inclusive a Ilha socialista, e também não admite países da América anglo-saxônica como os Estados Unidos e Canadá e propugna a integração da América Latina ${ }^{273}$.

Por fim, na escala sub-regional, temos a UNASUL, atuando apenas na América do Sul, através do Conselho de Defesa Sul-Americano (CDS) como um mecanismo de cooperação militar e defesa. Todas essas iniciativas contribuem para uma "comunidade de segurança", conceito criado por Karl Deutsch, em 1957, em que os conflitos entre os membros da comunidade serão resolvidos sem guerra, mas pelo diálogo ${ }^{274}$. Se esse modelo se multiplicar em outros continentes, a hegemonia norte-americana será seriamente ameaçada. Para Joseph Nye, "há uma lei natural da política internacional:

\footnotetext{
272 WEIFFEN, Brigitte. The Inter-American Security System: Changes and Challenges. Carta Internacional, São Paulo, v. 5, n 1, p. 25, 2010.

273 MARTINS, Umberto. A Celac desenha uma nova realidade geopolítica na América Latina. Portal Vermelho. São Paulo, s.d. Disponível em:

<http://www.vermelho.org.br/coluna.php?id_coluna_texto=5688\&id_coluna=35>. Acesso em: 05 set. 2015.

274 DEUTSCH, Karl Wolfgang et al. Political Community and the North Atlantic Area: International Organization in the Light of Historical Experience. Princeton: Princeton University, 1957.
} 
quando uma nação se torna excessivamente poderosa, as outras se unem justamente para contrabalancear esse poder", como já advertia Lord Acton, “o poder corrompe"275.

${ }^{275}$ NYE, Joseph. O Paradoxo do Poder Americano. São Paulo: Editora da Unesp, 2002, p. 27. 


\title{
CAPÍTULO III - O PAPEL DO ESTADO BRASILEIRO NA AMÉRICA LATINA
}

\begin{abstract}
A República Federativa do Brasil buscará a integração econômica, política, social e cultural dos povos da América Latina, visando à formação de uma comunidade latino-americana de nações ${ }^{276}$.
\end{abstract}

No terceiro capítulo, finalmente, abordaremos a inserção do Estado brasileiro na América Latina, inicialmente com a Operação Pan-Americana e, em seguida, o estudo será direcionado para o processo de integração regional na agenda do Itamaraty, desde 1960 até os nossos dias. Analisaremos a América Latina do ponto de vista do seu coeficiente de poder para demonstrar que a região possui excedentes de recursos suficientes para gerar poder em escala global. Explicaremos a crise política brasileira e seu desdobramento geopolítico na região. Utilizaremos ainda a teoria "meridionalista" brasileira de André Martin, para mostrar que a América Latina é a posição (lage) geográfica do Brasil em escala regional e um espaço vital para a projeção mundial do nosso país.

\section{Operação Pan-Americana e a inserção do Brasil na América Latina}

O conceito de "América Latina" no Brasil não foi muito assimilado porque, historicamente, desde o século XIX, o Estado brasileiro era um pouco outsider nesses movimentos de integração regional, devido aos problemas que o país enfrentava em torno de sua própria unidade territorial que, na época de sua independência, queria evitar a fragmentação hispano-americana. Por essa razão, a perspectiva de se integrar à América Latina era um pouco distante. Isso vai começar a mudar apenas na segunda metade do século XX, quando o presidente Juscelino Kubitschek (1956-1960) lança a Operação Pan-Americana (OPA), em 1958, buscando o multilateralismo nas relações dos Estados Unidos com a América Latina. Talvez esse seja um dos fatores que corroboraram para que o Brasil pensasse a questão da integração regional num viés estado-unidense em detrimento de sua latino-americanidade. De todo modo, representou o marco inicial da inserção do Brasil na região.

\footnotetext{
${ }^{276}$ Parágrafo único do art. $4 .^{\circ}$ da Constituição Federal.
} 
O lançamento da OPA foi uma mudança importante na chancelaria brasileira, constituindo o início da integração do Brasil na América Latina, após anos de relações centradas nos Estados Unidos e Europa ${ }^{277}$. Ainda nessa linha, Francisco Doratioto e Carlos Vidigal observam que representou o início da latino-americanização da política exterior brasileira $^{278}$.

Moniz Bandeira destacou a reivindicação brasileira, mediante a OPA, por uma maior atenção de Washington às necessidades de desenvolvimento da América Latina, levando os Estados Unidos a dialogar com todos os países da região, enquanto conjunto, como se fosse um só bloco, e não com cada um separadamente, como até então eles fizeram $^{279}$.

Em 1958, o vice-presidente dos Estados Unidos, Richard Nixon, realiza uma série de visitas programadas à América do Sul: Argentina, Uruguai, Paraguai, Bolívia, Peru, Equador, Colômbia e Venezuela. O Brasil ficava de fora porque já estava agendada uma visita do secretário de Estado John Foster Dulles, nesse mesmo ano, e também Nixon já havia estado no país, em 1956, comparecendo à posse de Juscelino Kubitschek. A viagem de Nixon tinha dois objetivos: a) prestigiar a posse do presidente da Argentina, Arturo Frondizi, num gesto que procurava demonstrar o apoio norteamericano aos novos governos democráticos que se consolidavam na região e, dessa forma, neutralizar em parte a imagem anterior de apoio a $\operatorname{ditaduras}^{280}$ e b) $\mathrm{o}$ Departamento de Estado e o Pentágono mantiveram a doutrina Truman no governo Eisenhower, por essa razão se preocupavam com o avanço do socialismo na região, e para contê-lo, haviam programado uma série de visitas para o ano de $1958^{281}$.

Contudo, Washington não contava com a impopularidade do seu governo na região. As manifestações antinorte-americanas, provocadas pela visita de Nixon, não foram por acaso, pois em janeiro desse mesmo ano, uma insurreição popular havia derrubado, na Venezuela, a ditadura do general Marcos Pérez Jiménez, sustentada

\footnotetext{
${ }^{277}$ LIGIERO, Luiz Fernando. A autonomia na política externa brasileira: a política externa independente e o pragmatismo responsável: momentos diferentes, políticas semelhantes? Brasília: Fundação Alexandre de Gusmão, 2011, p. 25.

${ }^{278}$ DORATIOTO, Francisco Fernando Monteoliva; VIDIGAL, Carlos Eduardo. Op. cit., 2014, p. 57.

${ }^{279}$ MONIZ BANDEIRA, Luiz Alberto. Op. cit., 2010, p. 293.

${ }^{280}$ A imagem da administração Eisenhower (e dos EUA, em geral), estava desgastada na América Latina, devido o apoio político aos governos ditatoriais de Manuel Odria, no Peru (1948-1956), Marcos Perez Jimenéz, na Venezuela (1952-1958), Rojas Pinilla, na Colômbia (1953-1957), e o regime militar, na Argentina (1955-1958), que derrubaram Perón do governo, obrigando-o a se exilar no Paraguai e, depois, na Espanha (SILVA, Alexandra de Mello e. A política externa de JK: a Operação Pan-Americana. Rio de Janeiro: CPDOC, 1992, p. 13).

${ }^{281}$ Ibidem, p. 16.
} 
igualmente pelos Estados Unidos ${ }^{282}$. Além disso, Washington havia deixado a América Latina à margem do Plano Marshall, desse modo, a região não conhecia os benefícios da cooperação então vigentes em outras áreas do globo ${ }^{283}$. Ou seja, aquela máxima de que "se você não pode ajudar, não atrapalhe", para os Estados Unidos, era justamente ao contrário, porque além de não ajudarem no desenvolvimento econômico da região, eles ainda atrapalhavam apoiando regimes totalitários no subcontinente.

Os protestos e manifestações populares ocorridos no Peru e na Venezuela levaram o Pentágono a deslocar tropas para suas bases no Caribe, a fim de realizar uma “operação-resgate”, caso fosse necessário ${ }^{284}$. Esse episódio levou o presidente Juscelino Kubitschek a enviar uma carta ao presidente Dwight Eisenhower, em 28 de maio de 1958, lamentando os incidentes enfrentados por Nixon, aproveitou o ensejo para falar sobre a necessidade de uma revisão das relações dos Estados Unidos com a América Latina $^{285}$, e propôs a OPA, cuja ênfase deveria recair doravante na superação da pobreza, por meio de um esforço conjunto em prol do desenvolvimento regional ${ }^{286}$.

Letícia Pinheiro explica que a proposta brasileira propugnava ser a pobreza interna dos países a geradora da subversão e não necessariamente a ameaça externa da Guerra Fria:

\begin{abstract}
Na prática, a OPA visava estimular o aumento de aporte de recursos públicos norte-americanos para os projetos de desenvolvimento dos países latinoamericanos com base em uma nova e interessante estratégia: invertendo a lógica da política externa norte-americana característica da Guerra Fria que percebia o comunismo como fonte de ameaça à segurança e à estabilidade política dos países ocidentais, a OPA propugnava ser esta ameaça uma consequência dos problemas sociais cuja causa profunda residia no subdesenvolvimento e na miséria, estes sim estímulos para a proliferação do ideário comunista ${ }^{287}$.
\end{abstract}

Amado Cervo e Clodoaldo Bueno explicam que a OPA era uma proposta de cooperação internacional de âmbito hemisférico, na qual se insistia na tese de que o desenvolvimento e o fim da miséria na América Latina seriam as maneiras mais

\footnotetext{
${ }^{282}$ MONIZ BANDEIRA, Luiz Alberto. Op. cit., 2014, p. 200.

${ }^{283}$ CERVO, Amado Luiz; BUENO, Clodoaldo. História da política exterior do Brasil. 3. ed. Brasília: Editora Universidade de Brasília, 2008, p. 290.

${ }^{284}$ DORATIOTO, Francisco Fernando Monteoliva; VIDIGAL, Carlos Eduardo. Op. cit., 2014, p. 77.

${ }^{285}$ LESSA, Antônio Carlos. Há cinquenta anos a Operação Pan-Americana. Revista Brasileira de Política Internacional. Brasília, v. 51, n. 2, p. 5, jul./dez. 2008.

${ }^{286}$ CERVO, Amado Luiz. Relações Internacionais da América Latina: velhos e novos paradigmas. Brasília: IBRI, 2001, p. 104.

${ }^{287}$ PINHEIRO, Letícia de Abreu. Política externa brasileira, 1889-2002. Rio de Janeiro: Jorge Zahar Ed., 2004, p. 32.
} 
eficazes de se combater a ameaça socialista na região ${ }^{288}$. A proposta do presidente Kubitschek foi bem recebida pelo presidente Eisenhower, e conversações foram postas em marcha. Como resultado imediato dessa iniciativa, a OEA criou um Comitê Especial dos representantes dos seus 21 membros, visando discutir e implementar as medidas propostas pela OPA $^{289}$. No entanto, no ano seguinte, Cuba irá adotar um regime socialista, o que irá mobilizar todos os esforços de Washington em erradicar o regime instalado na ilha caribenha. Agora, a prioridade do Pentágono seria conter o avanço do socialismo na região.

O presidente seguinte, John Kennedy, irá se "apropriar" da ideia da OPA, adaptando-a aos objetivos da política de segurança dos Estados Unidos na Guerra Fria. O lançamento da Aliança para o Progresso, em 13 de março de 1961, concentrava-se pesadamente no combate ao socialismo, seu caráter assistencialista a distanciava do desenvolvimento econômico na forma proposta por Kubitschek ${ }^{290}$. Enquanto a Aliança para o Progresso priorizava capitais privados e as relações bilaterais, a OPA enfatizava a utilização de capitais públicos e o multilateralismo nas relações internacionais da América Latina ${ }^{291}$.

Embora a iniciativa brasileira tenha tido poucos resultados efetivos, contribuiu para a inserção do Brasil na América Latina, sendo a primeira tentativa de estabelecer uma coordenação regional em favor do desenvolvimento ${ }^{292}$. A iniciativa ganha vulto quando examinamos o seu legado para a política externa brasileira: a) a reivindicação de um novo lugar para o país na política em escala regional e mundial; b) uma nova construção de autonomia nas suas relações com os Estados Unidos; e c) a valorização do multilateralismo nas relações exteriores do Brasil ${ }^{293}$.

Como resultados da OPA, comumente, costuma-se apontar apenas o Banco Interamericano de Desenvolvimento (BID), fundado em 1959, com a finalidade de financiar projetos de desenvolvimento na América Latina. Mas, na verdade, a

\footnotetext{
${ }^{288}$ CERVO, Amado Luiz; BUENO, Clodoaldo. Op. cit., 2008, p. 290.

${ }^{289}$ Ibidem, p. 292.

${ }^{290}$ DORATIOTO, Francisco Fernando Monteoliva; VIDIGAL, Carlos Eduardo. Op. cit., 2014, p. 78.

291 VISENTINI, Paulo Gilberto Fagundes. Política exterior e desenvolvimento (1951-1964): o nacionalismo e a política externa independente. Revista Brasileira de História. São Paulo: ANPUH/Marco Zero, v. 14, n. 27, p. 103, 1994.

${ }^{292}$ DORATIOTO, Francisco Fernando Monteoliva; VIDIGAL, Carlos Eduardo. Op. cit., 2014, p. 78.

${ }^{293}$ LESSA, Antônio Carlos. Op. cit., 2008, p. 5.
} 
Associação Latino-Americana de Livre Comércio (ALALC) e a Aliança para o

Progresso do presidente Kennedy foram desdobramentos da proposta brasileira ${ }^{294}$.

\subsection{A integração regional na agenda do Itamaraty}

A integração regional da América Latina começou na década de 1960 com a fundação da ALALC em decorrência das discussões da Comissão Econômica para a América Latina e o Caribe (CEPAL) ${ }^{295}$, que pensou numa ideia de criar uma zona de

\footnotetext{
${ }^{294}$ CERVO, Amado Luiz; BUENO, Clodoaldo. Op. cit., 2008, p. 292.
}

${ }^{295}$ O economista argentino Raúl Prebisch (1901-1986) observou que a divisão internacional do trabalho preconizada por David Ricardo beneficiava apenas os grandes centros industriais, em detrimento da América Latina, cuja inserção internacional se dava na periferia do sistema econômico mundial, especializando-se na produção de alimentos e matérias-primas de baixo valor, ao passo que os produtos que importava eram industrializados com alto valor. Essa constatação empírica leva Prebisch a chamar esse processo de deteriorização dos termos de intercâmbio, pois os preços dos produtos primários tendem a cair, em decorrência do aumento de sua oferta no mercado mundial, beneficiando os países centrais que importam nossos produtos mais baratos. Para ele, isso criava um desequilíbrio estrutural na balança de pagamentos dos países latino-americanos resultando no seu subdesenvolvimento (PREBISCH, Raúl. O desenvolvimento econômico da América Latina e alguns de seus problemas principais. In: BIELCHOSWSKY, Ricardo (Org.). Cinquenta anos de pensamento na CEPAL. Rio de Janeiro: Record, 2000 , v. 1, p. 69-72). A conclusão de Prebisch, o colocava em direta oposição à teoria clássica do comércio internacional de David Ricardo, publicada em 1817, onde defendia que cada país deveria se especializar na produção de bens em que seja relativamente mais eficiente, pois isso seria benéfico para todas as nações. Assim, o que explica o comércio internacional, para ele, não é a vantagem absoluta de Adam Smith, mas sim a vantagem comparativa. Segundo Ricardo, esse deve ser o princípio que determina a divisão internacional do trabalho (RICARDO, David. Princípios de Economia Política e Tributação. Tradução Paulo Henrique Ribeiro Sandroni. São Paulo: Nova Cultural, 1996. Original inglês, p. 97). Ainda nessa linha, Prebisch chegou à conclusão de que a teoria clássica do comércio internacional ricardiana sustenta mecanismos que reproduzem as condições do subdesenvolvimento, perpetuando-as no tempo, ou seja, convertendo-as em estruturas permanentes. Por essa razão, ele substituiu a ideia de Ricardo pautada na divisão internacional do trabalho e a especialização dos mercados pela visão de um mundo dividido em duas metades, o centro e a periferia (CERVO, Amado Luiz. Inserção Internacional: formação dos conceitos brasileiros. São Paulo: Saraiva, 2008, p. 14). Nesse contexto que a CEPAL surgiu, em 1948, no âmbito das Nações Unidas, defendendo que apenas por intermédio da industrialização, se resolveria o problema do subdesenvolvimento latino-americano. Para tanto, buscaram aplicar um "Plano Marshall" para a região através da criação de um mercado intra-regional que estimulasse a industrialização dos países, por meio da política de substituição de importações. Todavia, o que a CEPAL não esperava era que embora alguns países da região se industrializassem nas décadas de 50, 60 e 70 como o Brasil, a Argentina e o México, a deteriorização dos termos de troca não diminuía, mas se mantiveram com perdas ainda mais acentuadas do que em outrora, quando se exportavam produtos agrícolas com baixos preços. Devido à incapacidade da CEPAL em resolver esse problema, os seus críticos formularam, na década de 1960, a teoria da dependência, desenvolvida em duas linhas de interpretações. A primeira vertente, mais ortodoxa, desenvolvida por Fernando Henrique Cardoso e Enzo Faleto. A outra vertente, de caráter marxista, elaborada por Ruy Mauro Marini, Theotônio dos Santos, Vânia Bambirra e André Gunder Frank. Esses últimos teóricos ligados a corrente marxista da dependência passaram a reconhecer o problema identificado pela CEPAL como verdadeiro, contudo, passaram a tratá-lo numa outra perspectiva. Dentre seus expoentes destaca-se Ruy Mauro Marini que escreveu A dialética da dependência, publicado em 1968, contudo, suas ideias eram tidas como subversivas, por essa razão ele e os demais teóricos foram exilados para o Chile durante o regime militar, e lá formularam a teoria da dependência. Seus textos permaneceram por muito tempo desconhecidos nas universidades brasileiras. 
livre comércio em escala regional para estimular a industrialização dos países latinoamericanos, por meio da política de substituição de importações ${ }^{296}$.

A proposta da CEPAL visava assegurar uma inserção mais favorável da América Latina no comércio internacional. Para atingir esse objetivo, os países da região precisavam diversificar as suas pautas de exportação, tentando incluir produtos mais elaborados. Dado que esses produtos não conseguiriam, num primeiro momento, concorrer com os similares fabricados pelos países industrializados, a saída seria criar não só um mercado doméstico, mas também um mercado em escala regional, onde os países pudessem intensificar o intercâmbio comercial entre si. A materialização do pensamento cepalino ocorreu com a criação da $\operatorname{ALALC}^{297}$.

A ALALC foi criada em 18 de fevereiro de 1960, com a assinatura do Tratado de Montevidéu pelo Brasil, Argentina, Paraguai, Uruguai, Peru, Chile e México. Posteriormente, aderiram ao tratado a Colômbia (1961), o Equador (1962), a Venezuela (1966), e a Bolívia (1967) ${ }^{298}$. O acordo previa o estabelecimento de uma área de livre comércio entre os países-membros e a gradual eliminação das taxas de importação e tarifas alfandegárias em um prazo máximo de 12 anos. A iniciativa, no entanto, se mostrou demasiada ousada por tentar integrar, naquele momento histórico, países com tantas assimetrias entre si, do ponto de vista político, econômico e territorial. A ALALC terminou se flexibilizando e se afastando cada vez mais dos seus objetivos iniciais ${ }^{299}$ :

Na análise das razões econômicas do definhamento da ALALC, deve-se levar
em conta o surgimento de graves diferenças entre os países, cujas causas
foram de várias origens. À medida que a negociação levava ao rebaixamento
de tarifas de produtos com baixa competitividade, que poderiam ser
compradas a preços menores em países externos à Associação, as tensões iam
aumentando. Ao mesmo tempo, questão essencial em todos os processos de
integração regional, vislumbravam-se crescentemente situações de
distribuição desigual de custos e benefícios. Enquanto alguns, sobretudo
Argentina, Brasil e México, obtinham resultados positivos, particularmente
no comércio de manufaturados, outros se encontravam em desvantagem.
Conflitos sobre o tratamento tarifário de produtos importantes, como petróleo
e trigo, foram aumentando as tensões. Certamente esta foi uma das razões

${ }^{296}$ SILVA, Alexandra de Mello e. Op. cit., 1992, p. 31.

${ }^{297}$ COSTA, Darc Antonio da Luz. Um Discurso de Estratégia Nacional: A Cooperação Sul-Americana como Caminho para a Inserção Internacional do Brasil. Tese de Doutorado apresentada ao Programa de Pós-Graduação em Engenharia de Produção da Universidade Federal do Rio de Janeiro. Rio de Janeiro, 1999, p. 82.

298 Tratado de Montevidéu em 1960. Disponível em:

<http://www2.uol.com.br/actasoft/actamercosul/espanhol/tratado_de_montevideo.htm> Acesso em: 10 maio 2017.

${ }^{299}$ PIERI, Vitor Stuart Gabriel de; TELES; Reinaldo Miranda de Sá; OLIVEIRA, Fabiana de. Op. cit., 2015, p. 30-1. 
importantes que acabou por levar um grupo de países ao Acordo de Cartagena, de maio de 1969, quando Bolívia, Chile, Colômbia, Equador e Peru criam o Grupo Andino. A percepção de prejuízos de parte dos países menores e médios acabou afetando a credibilidade do bloco ${ }^{300}$.

As assimetrias dos países da região levaram a uma estagnação das negociações comerciais, sobretudo em torno da eliminação gradual das tarifas alfandegárias. Diante disso, houve uma ruptura no seio da associação por parte dos países andinos, que celebraram o Acordo de Cartagena, criando o Pacto Andino, em 1969 - mais tarde Comunidade Andina (CAN). Consequentemente, os países tiveram que reformular o Tratado de Montevidéu 1960 para flexibilizá-lo a fim de poderem avançar nas negociações comerciais resultando na substituição da ALALC pela Associação LatinoAmericana de Integração (ALADI) ${ }^{301}$.

A ALADI foi criada em 12 de agosto de 1980, com a assinatura do Tratado de Montevidéu. Os países membros fundadores da associação são: Brasil, Argentina, Paraguai, Uruguai, Chile, Bolívia, Peru, Equador, Colômbia, Venezuela e México. Nos anos seguintes, também aderiram ao tratado Cuba (1999) e Panamá (2012). Atualmente, a Nicarágua está em processo de adesão ${ }^{302}$. Juntos representam um mercado de 561,9 milhões de habitantes ${ }^{303}$ e um território de 20 milhões de $\mathrm{km}^{2}$. A associação possui uma sede na cidade de Montevidéu, Uruguai. Continuando com o processo iniciado pela ALALC, visa contribuir para a integração regional latino-americana, mas com objetivos menos ambiciosos. A associação abandonou a ideia de criação de uma área de livre comércio na América Latina e, em seu lugar, passou a defender acordos de preferências econômicas entre os países, o que permitiu a formação de novos arranjos em escala subregional. Com um maior dinamismo econômico, essas novas entidades poderão futuramente ser conjugadas formando um bloco mais amplo que resulte finalmente na integração regional da América Latina. Por essa razão, a organização pode ser considerada como um acordo "guarda-chuva" institucional e normativo que abrange

\footnotetext{
300 BUENO, Clodoaldo; RAMANZINI JÚNIOR, Haroldo; VIGEVANI, Tullo. Uma Perspectiva de Longo Período sobre a Integração Latino-americana Vista pelo Brasil. Contexto internacional, Rio de Janeiro, v. 36, n.2, p. 566-7, dez. 2014.

${ }^{301}$ ARAUJO, Assilio Luiz Zanella; FERRARI FILHO, Fernando. O processo de integração na América do Sul: da ALALC à UNASUL. Ensayos de Economía, Medellín, Colômbia, v. 25, n. 46, p. 105, 2015.

${ }^{302}$ Associação Latino-Americana de Integração. Disponível em:

$<$ http://www.aladi.org/sitioAladi/quienesSomos.html>. Acesso em: 10 maio 2017.

${ }^{303}$ Relatório da ALADI. Indicadores Sócioeconômicos, 2016. Disponível em: $<$ http://www.aladi.org/nsfaladi/sitioAladi.nsf/indicadorEcDatosP.xsp?databaseName=CN=websrv/O=AL ADI!!nsfaladi\%5Cindicado.nsf\&documentId=251AEB7DB8C1F624032567B4005CD7E6\&action=editD ocument>. Acesso em: 14 fev. 2017.
} 
outras iniciativas de integração econômica menores, apresentando-se como uma alternativa mais flexível para alcançar a unidade latino-americana ${ }^{304}$.

Após décadas de governos militares e uma onda de golpes de Estado na América Latina, Brasil e Argentina retomaram a democracia. Em 1984, Raúl Alfonsin assumiu o governo na Argentina, e no ano seguinte, José Sarney chegou à presidência do Brasil. Os dois presidentes civis "decidiram lançar um processo de integração bilateral gradual com vistas a promover o desenvolvimento econômico"305. Desse ato político nasceu a Declaração de Iguaçu, em 29 de novembro de 1985 - documento que lançou as bases para o MERCOSUL ${ }^{306}$. Oito meses depois, em 28 de julho de 1986, Sarney visitou Buenos Aires e firmou com Alfonsín a Ata para a Integração Brasil-Argentina, que instituiu o Programa de Integração e Cooperação Econômica (PICE) ${ }^{307}$, com 12 protocolos anexos que mencionava, pela primeira vez, a intenção de instituir um espaço geoeconômico comum ${ }^{308}$.

Segundo Moniz Bandeira, a associação da Argentina com o Brasil, na década de 80, não foi por acaso; a Guerra das Malvinas havia provocado um dissenso político tanto com a Comunidade Econômica Europeia (CEE), quanto com os Estados Unidos, em virtude do apoio que deram à Grã-Bretanha. Diante disso, só restava aos argentinos o caminho da integração regional ${ }^{309}$.

Em 29 de novembro de 1988, o Brasil e a Argentina assinaram o Tratado de Integração, Cooperação e Desenvolvimento, com o objetivo de instituir um mercado comum no prazo máximo de dez anos ${ }^{310}$. Contudo, em 20 de dezembro de 1990, os dois países assinaram o Acordo de Complementação Econômica n ${ }^{\circ}$ 14, dentro da ALADI,

\footnotetext{
${ }^{304}$ MILANI, Carlos Roberto Sanchez et al. Atlas da política externa brasileira. Rio de Janeiro: EdUERJ; Buenos Aires: Clasco, 2015, p. 82.

305 GUIMARÃES, Samuel Pinheiro. O mundo multipolar e a integração sul-americana. Comunicação \& Política, Rio de Janeiro: Cebela, v. 25, n. 3, p. 179, set./dez. 2007.

306 Do ponto de vista geopolítico, a Guerra do Paraguai (1864-1870) foi o núcleo geohistórico da integração regional sul-americana porque "pela primeira vez, coincidiam os interesses do Brasil e da Argentina nas questões platinas" que permitiu a formação da Tríplice Aliança entre os dois antigos rivais e o Uruguai contra o Paraguai que, derrotado, viu as suas fronteiras serem redefinidas após a guerra alterando assim a balança de poder na região. (DORATIOTO, Francisco Fernando Monteoliva. Guerra do Paraguai. In: MAGNOLI, Demétrio. (Org.). História das Guerras. 1. ed. São Paulo: Contexto, 2006, p. 257).

${ }^{307}$ MENEZES, Wagner. Mercado Comum do Sul (MERCOSUL). In: MERCADANTE, Araminta de Azevedo; CELLI JUNIOR, Umberto; ARAUJO, Leandro Rocha de. (Org.). Blocos Econômicos $e$ Integração na América Latina, África e Ásia. Curitiba: Juruá, 2006, v. 1, p. 140.

${ }^{308}$ MONIZ BANDEIRA, Luiz Alberto. Op. cit., 2010, p. 457-58.

${ }^{309}$ Ibidem, p. 462.

310 ALMEIDA, Paulo Roberto de. O Mercosul no contexto regional e internacional. São Paulo: Aduaneiras, 1993, p. 77.
} 
reduzindo pela metade os prazos acordados no tratado de 1988. Isto é, foi reduzido de dez para cinco anos o prazo para a remoção de todas as barreiras tarifárias e não tarifárias ao intercâmbio recíproco de mercadorias. Com isso, os presidentes Carlos Menem (1989-95 e 1995-99) e Collor de Mello (1990-92) precipitaram, para 31 de dezembro de 1994, o ritmo das políticas de abertura econômica e reforma aduaneira, visando à liberalização comercial, em detrimento do tratado de 1988, que previa a integração gradual, flexível e equilibrada até $1999^{311}$.

Posteriormente, decidiu-se estender o mercado comum aos dois outros vizinhos - Paraguai e Uruguai - sendo então celebrado entre os quatros países o Tratado de Assunção, em 26 de março de $1991^{312}$, com vistas a criar o Mercado Comum do Sul (MERCOSUL). O seu propósito é ser uma região coesa que permita a integração econômica, política e social entre os países que o integram, fortalecendo os vínculos entre os cidadãos do bloco, contribuindo para uma melhor qualidade de vida e, também, ser uma plataforma para enfrentar a globalização das grandes potências do Hemisfério Norte. A configuração atual do MERCOSUL encontra seu marco institucional no Protocolo de Ouro Preto, assinado em 17 de dezembro de 1994. O Protocolo reconhece a personalidade jurídica de direito internacional do bloco, atribuindo-lhe, assim, competência para negociar, em nome próprio, acordos com terceiros países, grupos de países e organismos internacionais. Também cabe destacar a sede administrativa do MERCOSUL em Montevidéu, Uruguai, que foi inaugurada em 15 de dezembro de 1997.

Tendo em vista que o Tratado de Assunção permite a adesão dos demais países membros da ALADI ao MERCOSUL, em 2012, o bloco passou pela primeira ampliação desde sua criação, com o ingresso definitivo da Venezuela como Estado Parte, unindo-se ao Brasil, à Argentina, ao Paraguai, e ao Uruguai. Atualmente, são sete os Estados Associados do MERCOSUL: o Chile (desde 1996); a Bolívia (em processo de adesão como Estado Parte, desde 2012); o Peru (desde 2003); o Equador e a Colômbia (desde 2004). Finalmente, a Guiana e o Suriname tornaram-se Estados Associados em 2013. Com isso, todos os países sul-americanos fazem parte do

\footnotetext{
${ }^{311}$ MONIZ BANDEIRA, Luiz Alberto. Op. cit., 2010, p. 480.

312 ALMEIDA, Paulo Roberto de. O desenvolvimento do Mercosul: progressos e limitações. Revista Espaço da Sophia, n. 43, p. 4, jul./set., 2011. Disponível em: <http://docplayer.com.br/4177752-Odesenvolvimento-do-mercosul-progressos-e-limitacoes.html>. Acesso em: 1 mar. 2017.
} 
MERCOSUL, seja como Estados Partes ou Associados ${ }^{313}$. Exceto a Guiana Francesa, em virtude de ser um território ultramarino da França no subcontinente. Em 2012, foi assinado o Protocolo de Adesão da Bolívia ao MERCOSUL, uma vez ratificado pelos congressos dos Estados Partes, fará do país andino o sexto membro pleno do bloco. Lembrando que o Congresso argentino, uruguaio e venezuelano já o ratificaram, faltam apenas o brasileiro e o paraguaio.

\section{Mapa 18: Primeiras iniciativas de integração regional da América Latina}

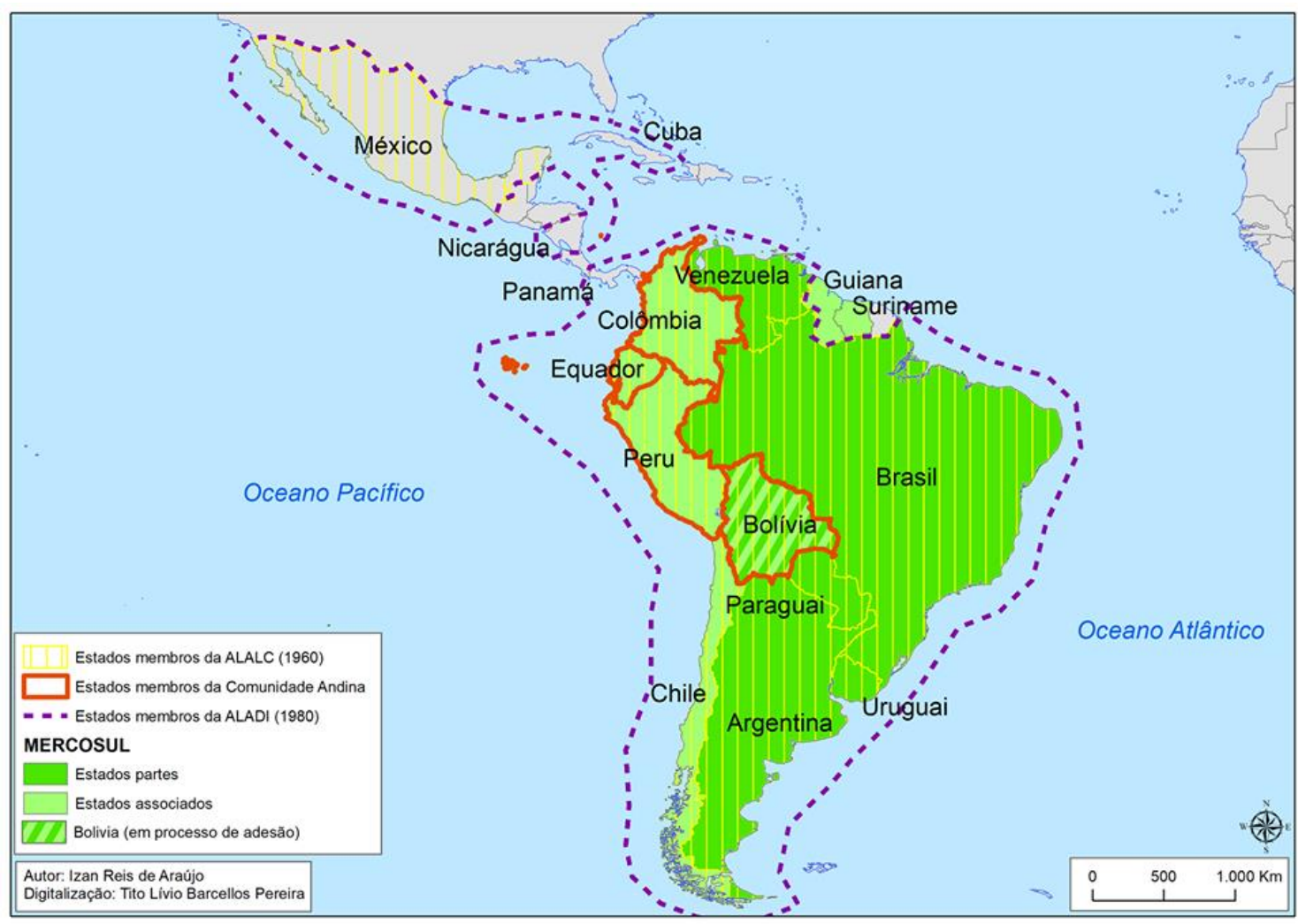

$\mathrm{Na}$ última década, o MERCOSUL demonstrou particular capacidade de aprimoramento institucional. Entre os inúmeros avanços, vale registrar a assinatura do Protocolo de Olivos, em 18 de fevereiro de 2002, que criou o Tribunal Permanente de Revisão; do Protocolo Constitutivo do Parlamento do MERCOSUL, assinado em 9 de dezembro de 2005, que criou o Parlamento do Sul (PARLASUL); do Instituto Social do MERCOSUL, criado em 18 de janeiro de 2007; do Instituto de Políticas Públicas de Direitos Humanos, em 24 de julho de 2009, bem como a aprovação, em 16 de dezembro

${ }^{313}$ MERCOSUL. Disponível em: <http://www.mercosul.gov.br/saiba-mais-sobre-o-mercosul〉. Acesso em: 15 fev. 2017. 
de 2010, do Plano Estratégico de Ação Social (PEAS) do MERCOSUL; e o estabelecimento do cargo de Alto Representante-Geral do MERCOSUL, em 17 de dezembro de 2010.

Merece especial destaque a criação, em 16 de dezembro de 2004, do Fundo para a Convergência Estrutural do MERCOSUL (FOCEM), por meio do qual são financiados projetos de convergência estrutural e coesão social, contribuindo para a mitigação das assimetrias entre os Estados Partes. Em operação, desde 2007, o FOCEM conta hoje com uma carteira de projetos de mais de US\$ 1,5 bilhão, com particular benefício para as economias menores do bloco (Paraguai e Uruguai). O fundo tem contribuído para a melhoria em setores como habitação, transportes, incentivos à microempresa, biossegurança, capacitação tecnológica e aspectos sanitários ${ }^{314}$.

Em 24 de julho de 1998, o bloco aprovou a cláusula democrática (Protocolo de Ushuaia), sobre o compromisso com a democracia e, em 20 de dezembro de 2011, assinou-se o Protocolo de Montevidéu (Ushuaia II), reiterando esse princípio entre os países membros. Segundo Wagner Menezes, “o MERCOSUL se encontra entre uma zona de livre-comércio incompleta e uma união aduaneira imperfeita, cujo objetivo central é chegar a um mercado comum"315.

\subsubsection{América do Sul e a UNASUL}

Localizado na América do Sul, o Estado brasileiro possui um espaço (raum) com dimensões continentais. Há cerca de 8,5 milhões de $\mathrm{km}^{2}$ de área terrestre e 4,5 milhões de $\mathrm{km}^{2}$ de área marítima, totalizando 13 milhões de $\mathrm{km}^{2}$. Seus 16,9 mil km de extensão, dos quais aproximadamente 12 mil correspondem à fronteira da Amazônia Legal, fazem fronteira com 9 países sul-americanos e um território ultramarino da França. O litoral brasileiro se estende por cerca de 7,4 mil km. No Atlântico Sul brasileiro, cruzam-se importantes rotas de navegação, vitais para a economia nacional. Aí estão localizadas as reservas do pré-sal brasileiro, de alto significado geoeconômico, geopolítico e geoestratégico $^{316}$. Ora, se a tese ratzeliana de que "espaço é poder" continua atual, então

\footnotetext{
${ }^{314}$ MERCOSUL. Disponível em: 〈http://www.mercosul.gov.br/saiba-mais-sobre-o-mercosul $>$. Acesso em: 15 fev. 2017.

${ }^{315}$ MENEZES, Wagner. Op. cit., 2006, p. 151.

${ }^{316}$ BRASIL. Ministério da Defesa. Op. cit., 2012, p. 17.
} 
o Brasil é, de certa forma, uma potência regional, devido aos fatores geográficos apresentados.

A adesão do México ao NAFTA, em 17 de dezembro de $1992^{317}$, levou o Itamaraty a abandonar o conceito de "América Latina" e, em seu lugar, o Estado brasileiro passou a defender uma política voltada para a "América do Sul”, que começou a se desenhar com o projeto de criação de um Área de Livre Comércio SulAmericana (ALCSA), feita pelo presidente Itamar Franco, em 1993, na cúpula do Grupo do Rio, em Santiago do Chile ${ }^{318}$. De acordo com Moniz Bandeira, o objetivo da ALCSA foi "constituir um contrapeso para o NAFTA, mediante a formação do espaço econômico sul-americano"319. Para ele, foi a partir daí que "os interesses do Brasil e do MERCOSUL se tornaram distintos dos interesses do México"320, pois enquanto o governo brasileiro estava buscando aprofundar a integração regional, ainda que de forma incipiente, o governo mexicano apontava numa outra direção, aprofundando suas relações com a América Anglo-saxônica. Por tudo isso, houve uma inflexão na política externa brasileira, em que o recorte sul-americano passou a ser uma prioridade para o projeto brasileiro de liderança regional ${ }^{321}$, sob a alegação de que as grandes questões geopolíticas, geoeconômicas e a integração regional só poderiam se desenvolver, pelo menos nesse momento histórico, no âmbito da América do Sul.

Conforme explica o Embaixador Celso Amorim:

Embora a integração latino-americana seja, além de um princípio constitucional, um objetivo legítimo, estava claro para mim que, dada as diferentes situações geopolíticas, tal objetivo só poderia ser atingido - se o fosse - no longuíssimo prazo $^{322}$.

Além disso, havia a percepção de que os países da América Central e Caribe estavam sob a influência hegemônica dos Estados Unidos, que possuem tratados de livre comércio e acordos preferenciais na região ${ }^{323}$.

\footnotetext{
${ }^{317}$ NAFTA. Disponível em: <http://www.naftanow.org/about/default_en.asp> Acesso em: 30 abr. 2017. 318 SANTOS, Luís Cláudio Villafañe Gomes. A América do Sul no discurso diplomático brasileiro. Brasília: Funag, 2014, p. 28.

${ }^{319}$ MONIZ BANDEIRA, Luiz Alberto. Op. cit., 2010, p. 487.

${ }^{320}$ MONIZ BANDEIRA. O Brasil e a América do Sul. Folha de S. Paulo, São Paulo, 22 maio 2005. Disponível em: <http://www1.folha.uol.com.br/fsp/opiniao/fz2205200509.htm〉. Acesso em: 10 set 2015. ${ }^{321}$ MILANI, Carlos Roberto Sanchez et al. Op. cit., 2015, p. 85.

322 AMORIM, Celso. Breves narrativas diplomáticas. São Paulo: Benvirá, 2013, p. 124.

${ }^{323}$ Conferência magna do Embaixador Celso Amorim no Seminário sobre "A Integração Sul-Americana", promovida pelo Centro Internacional Celso Furtado e o Conselho Nacional do Sesi, em 30 de setembro de 2015. Disponível em: <https://www.youtube.com/watch?v=CS0vQa1jiMM>. Acesso em: 4 maio 2017.
} 
Posteriormente, Fernando Henrique Cardoso se apropria do conceito de “América do Sul" formulado pelo governo Itamar Franco e convoca a I Reunião de Presidentes da América do Sul, realizada em Brasília, em 2000. Foi a primeira vez que os presidentes sul-americanos se reuniram apenas entre si. Antes já havia a Cúpula das Américas, mas uma reunião exclusiva para os países da América do Sul foi uma iniciativa inédita do Brasil. Desse encontro resultou o lançamento da Iniciativa para a Integração da Infraestrutura Regional Sul-Americana (IIRSA), dentro da lógica do regionalismo aberto $^{324}$, isso não é por acaso, mas porque justamente naquela época os Estados Unidos buscavam ampliar a sua zona de influência em toda a América Latina através da criação de uma Área de Livre Comércio das Américas (ALCA) ${ }^{325}$. Embora a IIRSA tenha integração energética, a iniciativa tem sido criticada pelo fato de seus projetos privilegiarem os corredores de exportação para o mercado global visando à exportação de commodities ${ }^{326}$. Tanto isto é certo que o diplomata João Mendes Pereira, que foi o responsável pelo tema no Itamaraty, disse, numa entrevista, ao jornal Folha de S. Paulo, que "o enfoque do Programa de Ação Estratégica do COSIPLAN será diferente da antiga IIRSA". Uma mudança relevante que o ministro assinala é que "em vez de corredores de exportação de insumos para fora do subcontinente, será privilegiado 'o desenvolvimento interno' da região", sendo o Brasil o grande beneficiado, pois os 11 países vizinhos são responsáveis por dois terços das exportações brasileiras de manufaturados, além de concentrarem os investimentos das empresas transnacionais de origem brasileira ${ }^{327}$.

Enquanto a proposta da ALCSA visava intensificar o comercio intra-regional, o BID - principal articulador do projeto IIRSA ${ }^{328}$ - sob o pretexto de combater a falta de

\footnotetext{
324 TAVARES, Rubens Diniz. Políticas Externas de Argentina e Brasil: Regionalismo e projetos de Integração na América do Sul 2003 a 2013. Dissertação de Mestrado apresentada ao Programa de PósGraduação em Integração da América Latina (PROLAM) da Universidade de São Paulo. São Paulo, 2015, p. 169.

325 III Cúpula das Américas. Declaração de Quebec, 20-22 abr. 2001. Disponível em:<http://www.ftaaalca.org/summits/quebec/declara_p.asp>. Acesso em: $21 \mathrm{dez} .2017$.

${ }^{326}$ COSTA, Alex Vander Lima. Integração Sul-americana: um teorema sem fim. Monografia apresentada ao Departamento de Estudos da Escola Superior de Guerra como requisito à obtenção do diploma do Curso de Altos Estudos de Política e Estratégia (CAEPE). Rio de Janeiro, 2012, p. 78.

327 ANTUNES, Cláudia; HENNEMANN, Gustavo. América do Sul relança projetos de infraestrutura. Folha de S. Paulo, São Paulo, 30 nov. 2011. Disponível em:

$<$ http://www1.folha.uol.com.br/fsp/mercado/12000-america-do-sul-relanca-projetos-deinfraestrutura.shtml >. Acesso em 21 dez. 2017.

328 O governo brasileiro na época da I Cúpula de Presidentes da América do Sul solicitou que o BID elaborasse um plano de ação para proposta do IIRSA. O estudo foi apresentado pelo banco, em dezembro de 2000 e está disponível em:
} 
infraestrutura física na região, buscava, na verdade, preparar o Brasil e a América do Sul para a implementação da ALCA, deixando o subcontinente relegado a um segundo plano na divisão internacional do trabalho, atribuindo o papel específico de produzir alimentos e matérias-primas para os grandes centros industriais.

Por essa razão, após a institucionalização, em 2009, do Conselho Sul-Americano de Infraestrutura e Planejamento (COSIPLAN), no seio da UNASUL, substituiu-se a IIRSA que tinha uma abordagem meramente técnica. Sendo assim, esse novo órgão passou a formular as políticas territoriais de integração regional na América do Sul com uma perspectiva mais estratégica para incentivar o comércio entre os países vizinhos e reduzir a influência do BID que a exemplo da OEA também é percebido como mais um organismo latino-americano capturado pelos Estados Unidos ${ }^{329}$. O que se pode perceber com isso é que embora haja uma identidade latino-americana e a diplomacia brasileira participe das organizações regionais como a OEA, não há uma correspondência geopolítica no sentido de estratégia como conseguiram fazer na América do Sul com o MERCOSUL, a UNASUL e o CDS. Por outro lado, na América do Sul, há uma geopolítica, mas não há uma identidade sul-americana.

No governo Lula, a América do Sul continuou sendo, desde o primeiro momento, a prioridade da política externa brasileira, como ele mesmo declarou na Sessão de posse, no Congresso, em 1 de janeiro de 2003:

\begin{abstract}
A grande prioridade da política externa durante o meu Governo será a construção de uma América do Sul politicamente estável, próspera e unida, com base em ideias democráticas e de justiça social. Para isso, é essencial uma ação decidida de revitalização do MERCOSUL, enfraquecido pelas crises de cada um de seus membros e por visões muitas vezes estreitas e egoístas do significado da integração. O MERCOSUL, assim como a integração da América do Sul em seu conjunto é, sobretudo, um projeto político $^{330}$.
\end{abstract}

Com a ascensão da "tróica", formada por Celso Amorim, Marco Aurélio Garcia e Samuel Pinheiro Guimarães à testa do Itamaraty, a América do Sul continuou sendo a prioridade da política externa brasileira. No discurso de posse como chanceler, o

<http://www.iirsa.org/admin iirsa_web/Uploads/Documents/Un\%20Nuevo\%20Impulso\%20a\%201a\%20I ntegracion\%20de\%201a\%20Infraestructura.pdf >. Acesso em 20 dez. 2017.

${ }^{329}$ PADULA, Raphael. Da IIRSA ao COSIPLAN da UNASUL: a integração de infraestrutura na América do Sul nos anos 2000 e suas perspectivas de mudança. In: NETO, Walter Antonio Desiderá (Org.). $O$ Brasil e novas dimensões da integração regional. 1. ed. Brasília: IPEA, 2014, p. 291-2.

${ }^{330}$ SILVA, Luis Inácio Lula da; AMORIM, Celso; GUIMARAES, Samuel Pinheiro. A Política externa do Brasil. Brasília: IPRI/Funag, 2003, p. 40-1. 
Embaixador Celso Amorim afirmou que "no governo Lula, a América do Sul será a nossa prioridade" ${ }^{331}$. Ainda nessa linha, o Embaixador Samuel Pinheiro Guimarães enfatizou que "a América do Sul se encontra, necessária e inarredavelmente, no centro da política externa brasileira" ${ }^{332}$. Na sua cerimônia de posse, como Secretário-Geral, ele também confirmou essa diretriz:

\begin{abstract}
A América do Sul constitui a prioridade da política externa, conforme deixado claro o Senhor Presidente da República e Vossa Excelência [Embaixador Celso Amorim]. A ação na América do Sul deverá atender ao objetivo de construção da integração econômica e da cooperação política e social, a partir de uma atitude brasileira que reconheça as assimetrias e procure equacioná-las de forma generosa ${ }^{333}$.
\end{abstract}

Por fim, o Assessor especial da presidência da República, desde 2003, Marco Aurélio Garcia afirmou que a "opção sul-americana foi o principal traço da política externa dos governos de Luiz Inácio Lula da Silva e Dilma Rousseff'334.

Com o presidente Lula no Palácio do Planalto, o Brasil buscou intensificar a aproximação com os países da América do Sul, recebendo todos os presidentes da região em seu primeiro ano de governo, e visitando todos os países do subcontinente em pouco mais de 24 meses $^{335}$. Além disso, foi criada a Subsecretaria-Geral da América do Sul (SGAS) no Itamaraty ${ }^{336}$.

Nesse contexto, o presidente peruano Alejandro Toledo entrou em contato com o Brasil, em 2003, querendo negociar um acordo comercial. Todavia, como o governo brasileiro não podia fechar nenhum acordo bilateral de livre comércio, sem os outros membros do MERCOSUL ${ }^{337}$, o acordo acabou envolvendo os demais países do bloco e, por conseguinte, os parceiros do Peru no âmbito da CAN. Desse modo, através de uma série de negociações entre os dois principais blocos econômicos do subcontinente, se

\footnotetext{
${ }^{331}$ SILVA, Luis Inácio Lula da; AMORIM, Celso; GUIMARAES, Samuel Pinheiro. Op. cit., 2003, p. 54.

${ }^{332}$ GUIMARÃES, Samuel Pinheiro. Op. cit., 2007, p. 169.

${ }^{333}$ SILVA, Luis Inácio Lula da; AMORIM, Celso; GUIMARAES, Samuel Pinheiro. Op. cit., 2003, p. 66.

${ }^{334}$ GARCIA, Marco Aurélio. Para nós, América do Sul é um grande ativo. Ópera Mundi, 18 out. 2014. Disponível em:

<http://operamundi.uol.com.br/conteudo/opiniao/38243/marco+aurelio+garcia+assessor+de+dilma+para+ nos+america+do+sul+e+um+grande+ativo.shtml>. Acesso em: 4 maio 2017.

${ }^{335}$ AMORIM, Celso. Op. cit., 2013, p. 127.

${ }^{336}$ SANTOS, Luís Cláudio Villafañe Gomes. Op. cit., 2014, p. 151.

${ }^{337}$ A decisão 32 do MERCOSUL, de 2000, estabelece o compromisso dos membros do bloco de negociar de forma conjunta os acordos comerciais que incluem preferências tarifárias com terceiros países. (MELLO, Patrícia Campos. Itamaraty quer mudar regra para fazer acordos sem países do Mercosul. Folha de São Paulo, São Paulo, 24 jun. 2016). Disponível em: <http://www1.folha.uol.com.br/mercado/2016/06/1785036-itamaraty-quer-mercosul-flexivel-paradestravar-acordos-comerciais.shtml>. Acesso em: 5 maio 2017.
} 
criou uma área de livre comércio sul-americana, concretizando o antigo projeto ALCSA, mas com outro nome. Com a conclusão do acordo MERCOSUL-CAN e o Chile, em 18 de outubro de 2004, a ideia de dar um componente político a esse novo arranjo regional amadureceu. Finalmente, em 8 de dezembro de 2004, o presidente peruano convocou a III Reunião de Presidentes da América do Sul, em Cusco. Nesse encontro, foi criada a Comunidade Sul-Americana de Nações (CASA). Os seus objetivos foram estabelecidos na Declaração de Cusco.

Em 16 de abril de 2007, durante a I Cúpula de Energia Sul-Americana, que foi realizada na Ilha Margarita, Venezuela, os Chefes de Estados decidiram mudar o nome da CASA para UNASUL ${ }^{338}$. Na visão da chancelaria brasileira, deveria permanecer o nome da organização porque tem um caráter mais aberto e plural ${ }^{339}$. No entanto, prevaleceu à opinião do presidente venezuelano Hugo Chávez, que advogava ser UNASUL um nome mais forte e que expressava sutilmente um contraponto ao malogrado projeto ALCA e a OEA ${ }^{340}$.

Por fim, na I Cúpula de Chefes de Estados, realizada em Brasília, em 23 de maio de 2008, foi criado o Tratado Constitutivo da UNASUL, que entrou em vigor apenas em 11 de março de $2011^{341}$, quando foi ratificado por nove Estados signatários conforme previsto no artigo 26 do instrumento.

Segundo Rubens Tavares, a UNASUL não possui o objetivo de conformar um mercado comum, opera dentro de um contexto de diversidade de visões de desenvolvimento e modelos econômicos, busca ser um espaço de articulação política ${ }^{342}$. Nessa linha, Samuel Pinheiro Guimarães salienta que o Brasil buscou o fortalecimento da América do Sul como um polo indispensável de maior autonomia em relação aos Estados Unidos, em favor de um sistema multipolar ${ }^{343}$. Mas, se a questão é essa, então o conceito de "América Latina" não é mais conveniente do que o recorte espacial sulamericano?

\footnotetext{
${ }^{338}$ UNASUL. Disponível em: 〈http://www.unasursg.org/es/historia >. Acesso em: 10 maio 2017.

339 TAVARES, Rubens Diniz. Op. cit., 2015, p. 175.

${ }^{340}$ Chávez: Presidentes acordaran llamar Unasur a integración política regional. La Tercera. Santiago, 16 abr. 2007. Disponível em:

<http://web.archive.org/web/20071018022526/http://latercera.cl/medio/articulo/0,0,3255_5702_2633398

50,00.html>. Acesso em: 10 maio 2017.

${ }^{341}$ Itamaraty. Disponível em:

<http://www.itamaraty.gov.br/pt-BR/notas-a-imprensa/2470-entrada-em-vigor-do-tratado-constitutivoda-unasul >. Acesso em: 11 maio 2017.

${ }^{342}$ TAVARES, Rubens Diniz. Op. cit., 2015, p. 176.

${ }^{343}$ GUIMARÃES, Samuel Pinheiro. Op. cit., 2005, p. 275.
} 
O próprio cientista político norte-americano, Samuel Huntington, em seu artigo intitulado The Clash of Civilizations?, publicado em 1993, na revista Foreign Affairs, reconhece que os países latino-americanos estão assentados em bases culturais comuns que lhes permitem serem vistos em conjunto como uma civilização. Por essa razão, ele criticou, ainda no mesmo artigo, o MERCOSUL e o CARICOM por não estarem conjugados, formando uma entidade econômica mais ampla, pois, segundo Huntington, os blocos regionais terão maior possibilidade de terem sucesso quando estiverem radicados numa civilização comum ${ }^{344}$.

Além do aspecto civilizacional levantado por Huntington, do ponto de vista geopolítico, a utilização do recorte sul-americano fragmenta a unidade hispanoamericana em duas zonas de influência: a América Central e o Caribe na órbita dos americanos e, a América do Sul na órbita brasileira. Como o Brasil quer liderar a região se ele próprio está ajudando a fragmentar a vizinhança hispano-americana sob o pretexto de uma suposta "identidade sul-americana de defesa"? Não faz sentido, mas, por incrível que pareça, o governo brasileiro ainda espera que a integração sulamericana "contribua para a unidade da América Latina" ${ }^{345}$. Ora, se há alguma "identidade de defesa", certamente não é do Brasil com os países da América do Sul, porque, historicamente, no século XIX, enquanto o Brasil tinha o reconhecimento internacional de sua independência em virtude de ter um governo regido por um monarca europeu, conforme previa a Ordem de Viena, a soberania das novas repúblicas hispano-americanas continuava ameaçada por Castela que ambicionava recolonizar a região. Por essa razão, Simon Bolívar escreveu a Carta da Jamaica e, posteriormente, propôs o Tratado de União, Liga e Confederação Perpétua no Congresso do Panamá. Ele desejava a integração regional em torno de uma confederação que fosse capaz de assegurar a unidade hispano-americana.

A fragmentação da América espanhola obviamente cria um "vácuo de poder"346 na região, permitindo o expansionismo dos Estados Unidos até a América do Sul. O

\footnotetext{
${ }^{344}$ HUNTINGTON, Samuel Phillips. The Clash of Civilizations?. Foreign Affairs, 1993. Disponível em: <https://www.foreignaffairs.com/articles/united-states/1993-06-01/clash-civilizations>. Acesso em: 13 maio 2017.

${ }^{345}$ BRASIL. Ministério da Defesa. Op. cit., 2012, p. 34-5.

${ }^{346}$ O conceito de "vácuo de poder" refere-se a um território geoestratégico formado por países que estão deficientes dos mais importantes elementos de poder. Isso acaba sendo um estímulo ao imperialismo e constitui pelo menos uma ameaça potencial à sobrevivência das nações daquela região (MORGENTHAU, Hans Joachim. A Política entre as nações: a luta pelo poder e pela paz. São Paulo: IOESP-UnB-IPRI, 2003, p. 115). Um exemplo emblemático de vácuo de poder foi quando o Congresso de Viena, em 1815,
} 
próprio geopolítico brasileiro Mario Travassos já alertava no seu livro Projeção Continental do Brasil para o perigo de uma potência extra-regional, ele apontava que o mar do Caribe e o canal do Panamá seriam os meios pelo quais se daria o extravasamento econômico e político dos Estados Unidos na América do Sul, pois, para ele, não se pode negar a "força de atração" que o istmo impõe entre os dois maiores oceanos do globo.

Em suas próprias palavras:

Está mais que evidente a possibilidade de o potencial yankee exceder o recipiente antilhano e canalizar-se por onde for mais fácil e necessário escoarem-se os seus interesses econômicos [...]. Embora não seja fácil prognosticar, tudo faz crer que os maiores progressos da infiltração dos interesses norte-americanos em nosso continente se farão pelas vias andinas e ao longo da costa do Pacífico. Corroboram nosso prognóstico, além das facilidades fisiográficas, o fracionamento político do território ${ }^{347}$.

Sua hipótese se confirmava empiricamente com a criação da Aliança do Pacífico, em 2011. Somando 215 milhões de habitantes e representando o que seria a nona economia mundial e o quinto maior mercado do mundo, este bloco econômico está ligado ao espaço geoeconômico mais alinhado ao Hemisfério Norte, em especial aos Estados Unidos e visa fazer um contraponto ao MERCOSUL ${ }^{348}$.

\subsubsection{América Latina e seu coeficiente de poder}

Nesse tópico, abordaremos quais são os coeficientes de poder da América Latina que contribuem para o seu maior protagonismo nos foruns internacionais. Para realizar esta análise, utilizaremos a teoria do poder perceptível elaborada pelo Professor Ray Cline, da Universidade de Georgetown.

De acordo com Cline, a distribuição de poder mundial entre os Estados demonstra que os países não são necessariamente iguais no campo das Relações Internacionais:

$\mathrm{Na}$ atmosfera retórica das Nações Unidas, todas as 152 nações soberanas do mundo são iguais, mas qualquer um concorda que no mundo real algumas

criou a Confederação Germânia na Europa central, justamente para ocupar o vácuo de poder que atraíra o expansionismo francês (KISSINGER, Henry. Diplomacia. São Paulo: Saraiva, 2012. p. 852).

347 TRAVASSOS, Mario. Op. cit., 1938, p. 76, 79.

${ }^{348}$ PIERI,Vitor Stuart Gabriel de; TELES;Reinaldo Miranda de Sá; OLIVEIRA, Fabiana de. Op. cit., p. 60. 
nações são mais iguais do que outras. Umas tem um poder tremendo, outras pequeno $^{349}$.

A fórmula matemática de Cline explica a distribuição do poder mundial e traduz de maneira inconfundível quais os fatores que influem na constituição do poder ${ }^{350}$.

Cline elaborou a seguinte equação:

$$
\mathrm{Pp}=(\mathrm{C}+\mathrm{E}+\mathrm{M}) \mathrm{x}(\mathrm{S}+\mathrm{W})
$$

Vamos identificar esses valores:

$$
\begin{aligned}
& \text { Pp = Poder Perceptível } \\
& \text { C = Massa Crítica (Território + População) } \\
& \text { E = Capacidade Econômica } \\
& \text { M = Capacidade Militar } \\
& \text { S = Concepção Estratégica (Strategy) } \\
& \text { W = Vontade de realizar a Estratégia Nacional (Will) }
\end{aligned}
$$

Observa-se, na fórmula acima, que no primeiro termo encontram-se os valores físicos do poder - população, território, economia e capacidade militar. No segundo termo, os fatores abstratos do poder - concepção estratégica e vontade. Para o General Meira Mattos, a fórmula de Cline ficaria mais completa se acrescentasse, no segundo termo, onde se reúnem os fatores abstratos, uma nova variável, $P$, que corresponderia ao Poder de Persuasão, isto é, sua capacidade de convencimento.

Em suas palavras:

Como uma exemplificação de que este valor $P$ está faltando no contexto do poder, diríamos que na recente Guerra do Vietnã, o que mais careceu aos Estados Unidos não foi tanto uma estratégia ou vontade de vencer a guerra, (mormente por parte do governo e combatentes) mas, essencialmente, o isolamento em que se viu o governo por ter sido incapaz de convencer aos seus aliados e ao seu próprio povo da justiça de sua causa, de persuadir sobre o interesse em se engajar em tal conflito. Ficou o governo norte-americano, por não ter tido força de persuasão, isolado em seu próprio país, depois de ter sido abandonado pelos seus tradicionais aliados ${ }^{351}$.

Segundo Meira Mattos, embora um país tenha uma estratégia formulada e um poder de dissuasão que expresse a firme vontade de vencer uma guerra - por parte do Estado e da sociedade - se ele não tiver poder de persuasão capaz de convencer os

\footnotetext{
${ }^{349}$ CLINE, Ray Steiner. World Power Assessment - A Calculus of Strategic Drift, 1975. In: MATTOS, Carlos de Meira. A Geopolítica e as projeções do poder. Rio de Janeiro: Biblioteca do Exército, 1977, p. 125.

${ }^{350}$ Ibidem, p. 131.

${ }^{351}$ Ibidem, p. 131-2.
} 
demais Estados, logo ele ficará isolado e consequentemente será derrotado ${ }^{352}$. A Guerra do Vietnã demonstra empiricamente essa tese.

Por isso mesmo, Meira Mattos propõe a seguinte fórmula:

$$
\mathrm{Pp}=(\mathrm{C}+\mathrm{E}+\mathrm{M}) \mathrm{x}(\mathrm{S}+\mathrm{W}+\mathrm{P})
$$

Tendo em vista os fatores físicos e abstratos de poder, vamos analisar o caso latino-americano. Iniciaremos pela primeira expressão de sua fórmula $(\mathrm{C}+\mathrm{E}+\mathrm{M})$. $\mathrm{Na}$ variável $C=$ Massa Crítica (Território + População), o território da América Latina chega a 21 milhões $\mathrm{km}^{2}$, representa mais do que o dobro do território americano com 9,3 milhões $\mathrm{km}^{2}$. No entanto, se somarmos o Canadá que possui uma extensão de 9,9 milhões de $\mathrm{km}^{2}$, então a América anglo-saxônica terá uma extensão territorial de 19,2 milhões de $\mathrm{km}^{2}$. Desse modo, haverá uma equipotência entre as duas regiões. Todavia, do ponto de vista estratégico, a América Latina terá vantagens, porque o seu território apresenta a maior reserva de petróleo, de água doce e de biodiversidade do planeta, mais de $90 \%$ de nióbio, mineral que é fundamental para a indústria aeroespacial, nuclear e automobilística. A América Latina também apresenta três regiões vitais no quadro geoestratégico mundial - o canal do Panamá, a base de lançamento de Alcântara (MA) e o Atlântico Sul.

O canal do Panamá é relevante porque abre novas linhas de comunicação, comércio e defesa entre o Atlântico e Pacífico. A base de lançamento de Alcântara é importantíssima pelo fato de sua localização, próxima à linha do Equador, possibilitar um menor gasto de combustível com foguete, que percorrerá uma distância menor até a órbita prevista para o satélite. Por fim, no Atlântico Sul, cruzam importantes rotas de navegação, vitais para a economia mundial. Aí estão localizadas as reservas do pré-sal brasileiro, de alto significado geoeconômico, geopolítico e geoestratégico.

Ainda analisando a variável $C$, com destaque para a População. Em termos populacionais, a América do Sul possui 414 milhões de habitantes ${ }^{353}$, mas a América Latina tem 641 milhões de habitantes ${ }^{354}$. Se levarmos ainda em conta o fato de que vivem nos Estados Unidos 55 milhões de latino-americanos ${ }^{355}$ e os franco-canadenses

\footnotetext{
352 Ibidem, p. 132.

353 BRASIL. Ministério das Relações Exteriores. Estatísticas para o estudo das relações internacionais: maio de 2016. Brasília: Instituto de Pesquisa de Relações Internacionais/ FUNAG, 2016.

${ }^{354}$ Anuário Estatístico da CEPAL, 2016, p. 13. Disponível em:

<http://repositorio.cepal.org/bitstream/handle/11362/40972/4/S1601037_mu.pdf >. Acesso em: 29 jul. 2017.

${ }^{355}$ United States Census Boreau, 2014. Disponível em:
} 
são mais de 8 milhões ${ }^{356}$, então culturalmente falando, os latino-americanos alcançam a espantosa cifra de 704 milhões de pessoas, o equivalente a cerca de $10 \%$ da população mundial. É quase o dobro da população formada pelos anglo-americanos, que na soma entre Estados Unidos ${ }^{357}$ e Canadá ${ }^{358}$ chegam à casa dos 361 milhões de habitantes. Nesta escala, os antilhanos e guianeses anglófonos são residuais.

Ainda nessa linha, é preciso observar, no mapa 19, que há um problema no conceito de "América Latina" por não considerar Quebec - onde a imensa maioria da população não utiliza o inglês e sim o francês, um idioma de origem latina - devido aos seus elevados indicadores de desenvolvimento ${ }^{359}$ que o enquadram no Hemisfério Norte numa perspectiva geoeconômica de regionalização Norte/Sul. Contudo, isso não quer dizer que Quebec não faça parte do Hemisfério Sul, do mesmo modo que a Austrália e a Nova Zelândia. Ademais, os québécois separados da América Latina nunca conseguiram concretizar a sua emancipação política. O que demonstra que a província possui uma característica singular dos países latino-americanos que é a luta por territórios não controlados, isto é, por soberania, a exemplo das Malvinas, Porto Rico e Guiana Francesa.

$<$ https://factfinder.census.gov/faces/tableservices/jsf/pages/productview.xhtml?src=bkmk>. Acesso em: 29 jul. 2017.

356 Statistics Canada, 2017. Disponível em:

<http://www.statcan.gc.ca/daily-quotidien/170615/dq170615c-eng.htm?HPA=1\&indid=40981 \&indgeo $=0$ >. Acesso em: 29 jul. 2017.

357 United States Census Boreau, 2017. Disponível em: 〈https://www.census.gov/popclock〉. Acesso em: 29 jul. 2017.

${ }^{358}$ Statistics Canada, 2017. Disponível em:

$<$ http://www.statcan.gc.ca/daily-quotidien/170615/dq170615c-eng.htm?HPA=1\&indid=40981 \&indgeo=0 $>$. Acesso em: 29 jul. 2017.

359 O Canadá apresenta um dos mais altos IDH do mundo $\left(0,913,9^{\circ}\right.$ lugar, em 2015) o que revela a alta qualidade de vida de seus habitantes. Seus indicadores sociais e econômicos demonstram isto. Sua taxa de mortalidade infantil fica em 8 para cada mil habitantes, a esperança de vida é de 82 anos e sua renda per capita é de US\$ 43.206. Dados do IBGE, 2016. Disponível em:

<http://paises.ibge.gov.br/\#/pt/pais/canada/info/indicadores-sociais>. Acesso em: 29 jul. 2017. 


\section{Mapa 19: Regionalização geoeconômica e geopolítica da América Latina}
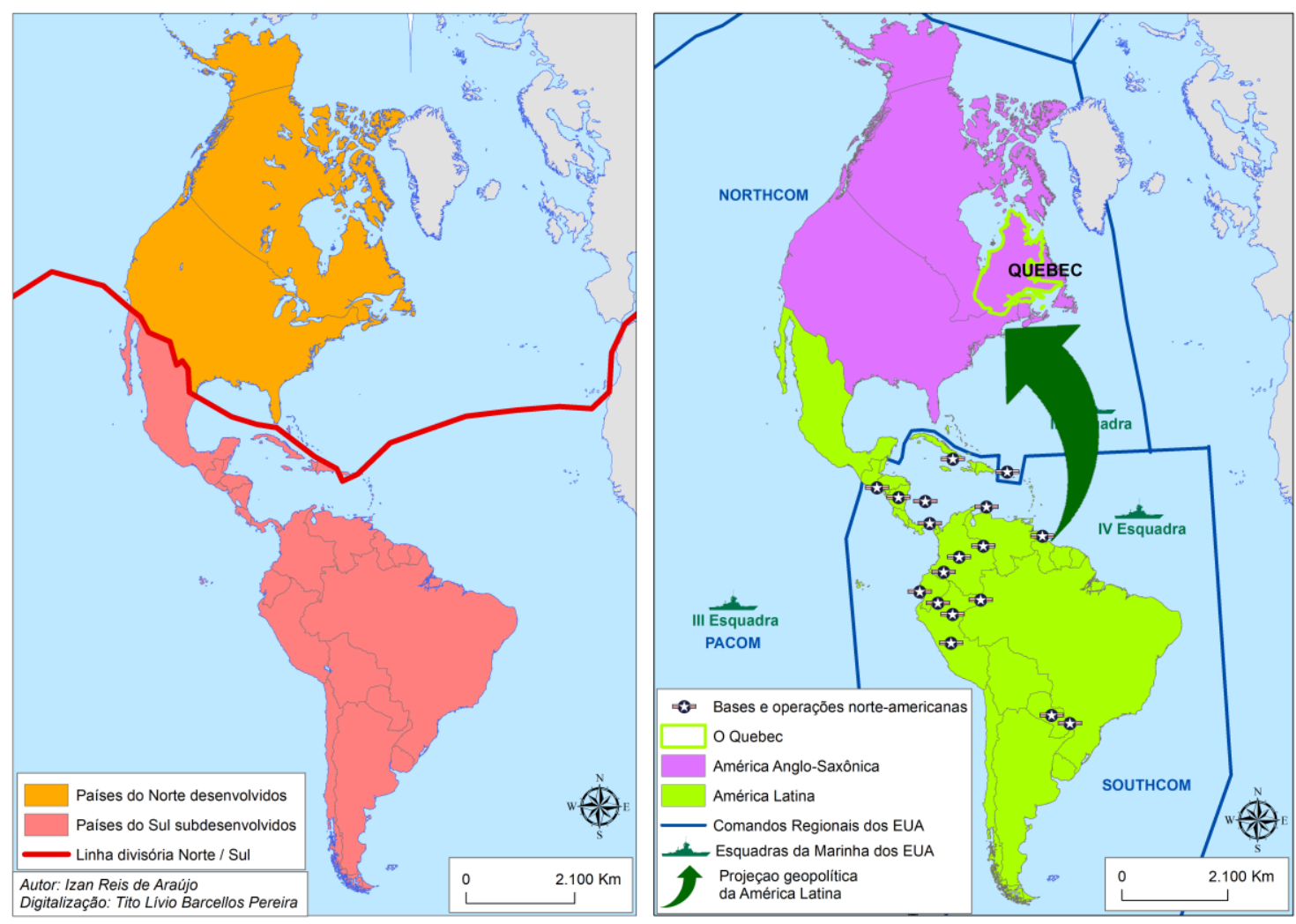

O mapa 19 ilustra ainda que, do ponto de vista geopolítico, se o Itamaraty defender apenas o recorte espacial sul-americano, os Estados Unidos estarão em nossas fronteiras com o Comando Sul, a Quarta Esquadra e suas bases militares instaladas na América do Sul, mas, se pensarmos no conceito de "América Latina", então, somos nós que nos projetamos nos Estados Unidos, culturalmente falando, com um "soft power" expresso nos 55 milhões de latino-americanos que vivem no país e mais os 8 milhões de franco-canadenses de Quebec. Nesse sentido, o próprio Gilberto Freire mostrou que a América Latina tem uma identidade cultural, religiosa e histórica própria, que nos permite ser considerados como um ethos supranacional ${ }^{360}$.

Na variável $E$ = Capacidade Econômica, a América Latina é a terceira maior economia mundial, com um PIB de aproximadamente US\$ 5,979 trilhões ${ }^{361}$, superando

\footnotetext{
${ }^{360}$ FREYRE, Gilberto. Americanidade e latinidade da América Latina e outros textos afins. Organizado por Edson Nery da Fonseca. Brasília: Ed. da Universidade de Brasília, 2003, p. 26-8.

${ }^{361}$ Anuário Estatístico da Cepal, 2014, p. 75. Disponível em: <http://interwp.cepal.org/anuario_estadistico/anuario_2014/PDF/AnuarioEstadisticoALC-2014.pdf>. Acesso em: 13 out. 2015.
} 
o PIB do Japão US\$ 4,788 trilhões e muito superior à soma do PIB da Alemanha 3,621 trilhões e do Canadá 1,57 trilhões $^{362}$.

Por fim, a variável $M=$ Capacidade Militar é a última variável dos fatores físicos de poder. Embora a América Latina esteja distante dos Estados Unidos, nós temos condições de ter uma capacidade militar equiparada aos países europeus. De fato, isso é uma meta realista, porque a América Latina reúne o quarto maior gasto militar mundial, com uma despesa em US\$ 66,6 bilhões, em 2016, superando a Arábia Saudita US\$ 63,7 bilhões e os países europeus - França, Reino Unido e Alemanha, individualmente, obviamente.

Gráfico 3: Os dez maiores gastos militares do mundo em 2016 (em bilhões US\$)

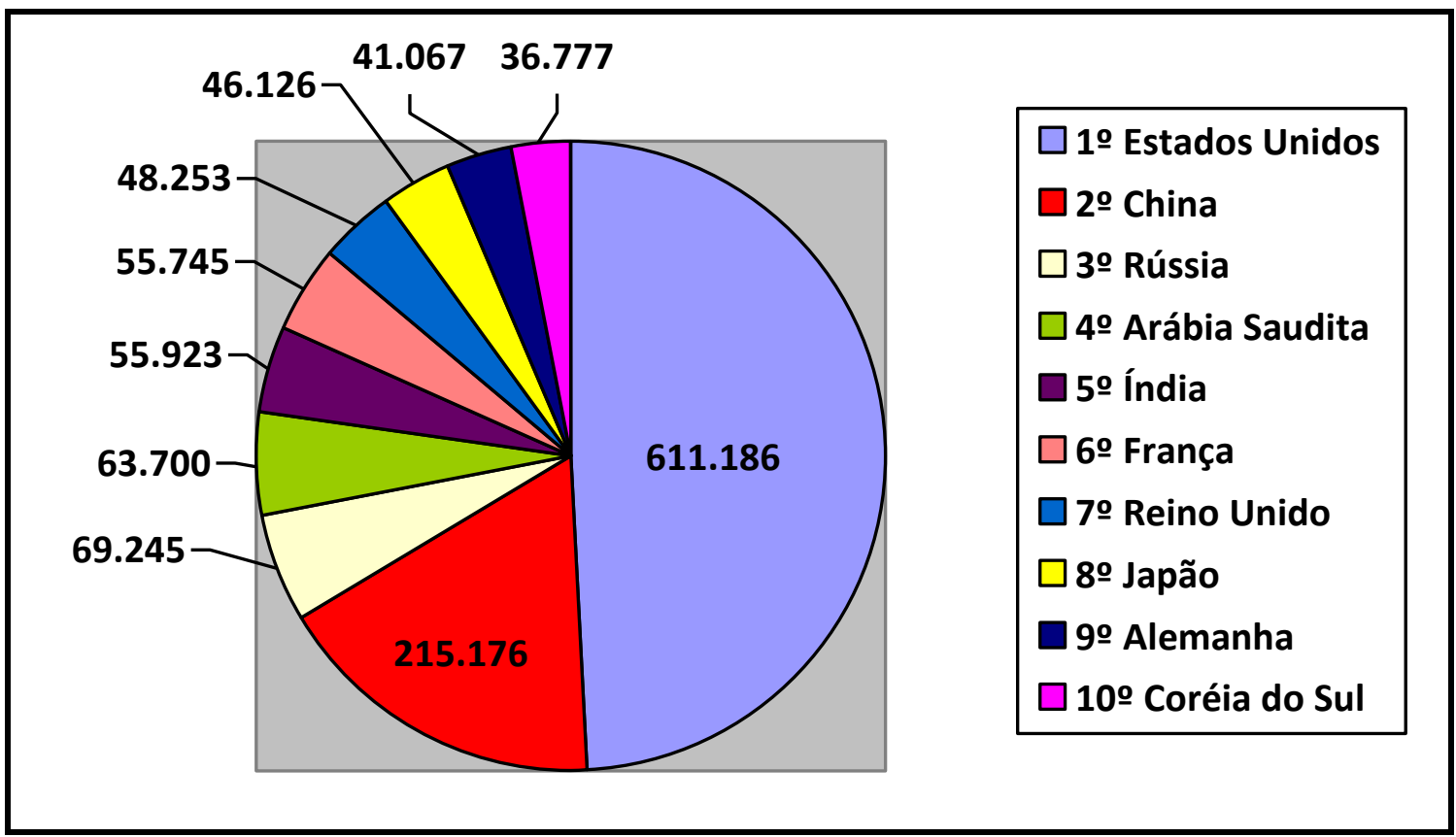

Fonte: www.sipri.org

A América Latina tem potencialidade para aumentar ainda mais o gasto militar, porque a média de gasto em defesa dos países latino-americanos não ultrapassa a marca $1,3 \%$ do PIB $^{363}$, diferentemente dos países do BRICS que têm uma média em torno de

\footnotetext{
${ }^{362}$ Fundo Monetário Internacional (FMI): World Economic Outlook Database 2014. Disponível em: $<$ http://www.imf.org/external/pubs/ft/weo/2014/02/weodata/weorept.aspx?pr.x=44\&pr.y=7\&sy=2012\&e $\mathrm{y}=2019 \& \mathrm{scsm}=1 \& \mathrm{ssd}=1 \&$ sort $=$ country $\& \mathrm{ds}=. \& \mathrm{br}=1 \& \mathrm{c}=156 \% 2 \mathrm{C} 158 \% 2 \mathrm{C} 132 \% 2 \mathrm{C} 112 \% 2 \mathrm{C} 134 \% 2 \mathrm{C} 111$ $\% 2 \mathrm{C} 136 \& \mathrm{~s}=$ NGDPD\%2CNGDPDPC\%2CPPPGDP\%2CPPPPC\&grp=0\&a=>. Acesso em: 13 out. 2015.

${ }^{363}$ Red de Seguridad y Defensa de América Latina (RESDAL). Atlas Comparativo de la Defensa en América Latina y Caribe. Edición 2014. Disponível em: http://www.resdal.org/assets/atlas-2016-espcompleto.pdf>. Acesso em: 20 abr. 2017.
} 
2,4\% do seu PIB ${ }^{364}$. Um exemplo de superação é a Índia que, em 2006, tinha um gasto militar de US\$ 35,7 bilhões, mas, em dez anos, o país atingiu o patamar de US\$ 55,9 bilhões que representa $2,5 \%$ do seu PIB, tornando-se o quinto maior gasto militar do mundo. Esse investimento contribui não só para uma maior capacidade militar do país, mas também para a educação, na medida em que as forças armadas têm muitas escolas de formação, também geram emprego, ciência e tecnologia para a sua sociedade.

Com relação ao segundo termo da fórmula de Cline $(\mathrm{S}+\mathrm{W})$, vamos incluir nela a variável $P$, conforme proposto por Meira Mattos, significando Poder de Persuasão. Assim, teremos a seguinte fórmula $(\mathrm{S}+\mathrm{W}+\mathrm{P})$. Buscaremos agora abordar a América Latina tendo em vista esses três fatores abstratos do poder.

Na variável $S=$ Strategy, vários países da América Latina apresentam suas concepções estratégicas de segurança e defesa nacional por meio da divulgação de documentos conforme demonstra o mapa 20.

${ }^{364}$ KLEIN, Cristian. Gasto militar brasileiro causa polêmica em seminário sobre os Brics. Valor Econômico, 9 jun. 2015. Disponível em: 〈http://www.valor.com.br/brasil/4087006/gasto-militarbrasileiro-causa-polemica-em-seminario-sobre-os-brics >. Acesso em: 20 abr. 2017. 
Mapa 20: Documentos de Políticas de Defesa na América Latina

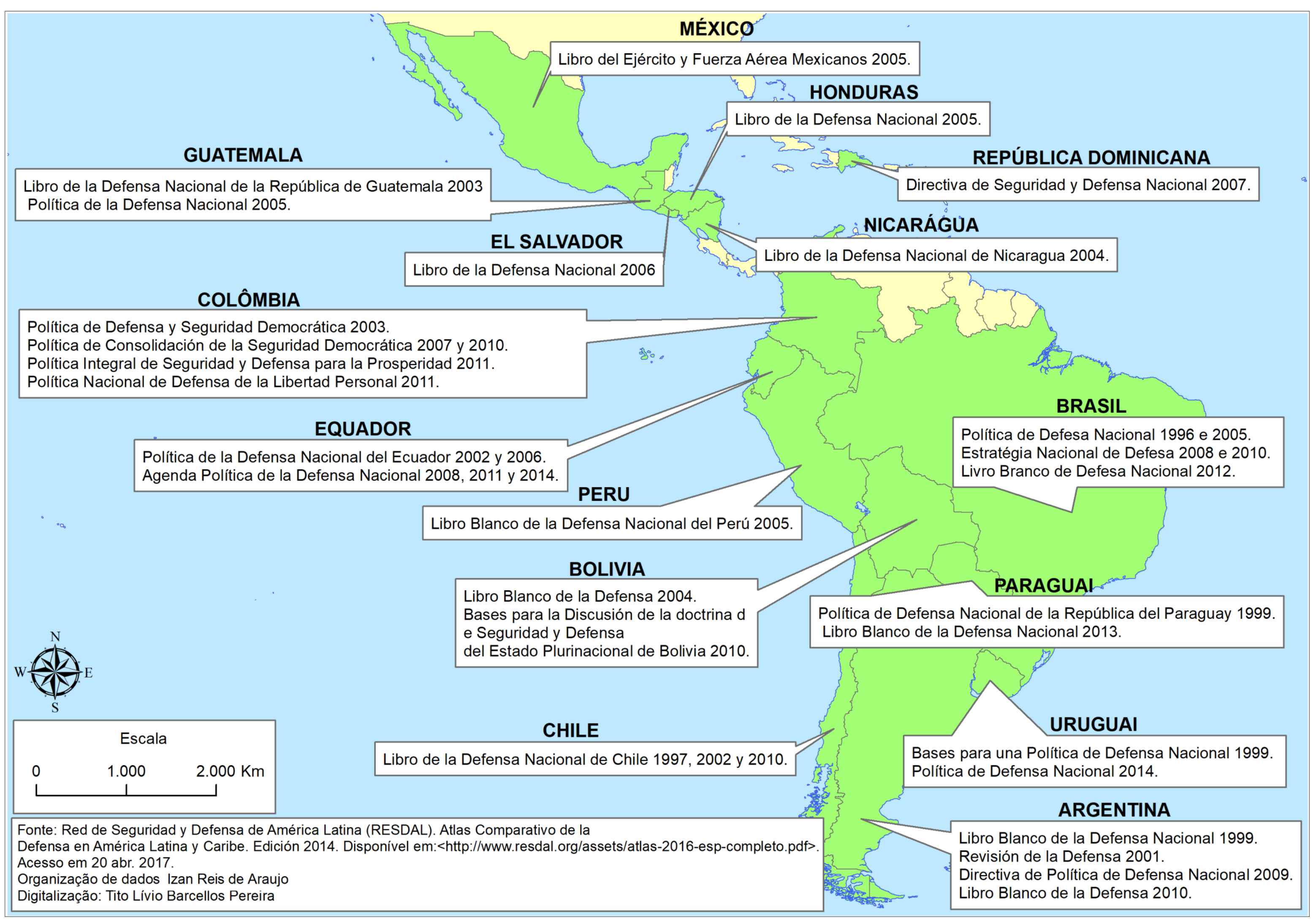


A produção de documentos que apresentam as concepções estratégicas dos países latino-americanos está aumentando significativamente, sobretudo depois de 2001. Isso reflete um cenário geopolítico mundial contemporâneo marcado pelo intervencionismo dos Estados Unidos, cuja estratégia de segurança nacional, denominada de Doutrina Bush, defende o unilateralismo e ataques preventivos. Esses documentos também são um estímulo para o aumento das "medidas de confiança mútua" entre os Estados vizinhos, evitando, assim, o "dilema de segurança".

No que tange à variável $W=$ Vontade de realizar a Estratégia Nacional, a criação do CDS, em 2008, e da Escola Sul-Americana de Defesa (ESUDE), em 2015, é a materialização da vontade dos Estados (governos e sociedades) em realizar uma estratégia de Defesa Nacional, sobretudo após as revelações de Edward Snowden, em 2013, que denunciou os programas de espionagem e rastreamento da Agência de Segurança Nacional (NSA, na sigla em inglês) dos Estados Unidos em vários países sulamericanos $^{365}$. Segundo Darc Costa, a nossa estratégia de defesa mais aconselhada, em face deste tipo de ameaças, é a dissuasão:

\begin{abstract}
Essa estratégia vem dando certo nos últimos conflitos em que países pequenos e médios, como a Somália e grupos armados na dividida exIuguslávia, querendo evitar a intervenção militar em seus territórios, apresentaram uma capacidade de resistência que os governos dos "grandes" não podem pagar, sem se submeterem a um tremendo desgaste político perante a opinião pública de seus países [...]. Finalizando, em face do quadro internacional de incertezas que vislumbramos para o futuro, temos de mostrar, claramente, que somos capazes de vender caro a nossa soberania ${ }^{366}$.
\end{abstract}

Finalmente, a variável $P=$ Poder de Persuasão. Nesse particular, a América Latina está em franca vantagem em relação à América Anglo-saxônica, porque conforme afirma Meira Mattos, o governo estado-unidense não tem "força de persuasão" 367 . Os Estados Unidos perderam a credibilidade perante a sociedade internacional depois de intervir no Iraque, em 2003, sem o consentimento das Nações Unidas, onde perderam 4.486 soldados, tiveram 33.184 seriamente feridos e mataram

\footnotetext{
${ }^{365}$ CARMO, Marcia. Escola de Defesa da Unasul começa a funcionar em busca de autonomia regional. BBC Brasil, 17 abr. 2015. Disponível em:

<http://www.bbc.com/portuguese/noticias/2015/04/150417_escola_defesa_unasul_mc>. Acesso em: 7 jun. 2016.

${ }^{366}$ COSTA, Darc Antônio da Luz. Segurança e Defesa: uma única visão abaixo do Equador. In: GUIMARÃES, Samuel Pinheiro; LLADÓS, José Maria (Orgs.). Perspectivas Brasil e Argentina. Rio de Janeiro: IPRI, 1999, v. 2, p. 62, 69.

${ }^{367}$ MATTOS, Carlos de Meira. Op. cit., 1977, p. 131.
} 
entre 106.00 e 115.000 iraquianos $^{368}$. O desrespeito ao direito internacional não para por aí, recentemente, o país bombardeou a Síria sob o pretexto de que o governo Bashar alAssad havia utilizado armas químicas contra a população síria, mas tal acusação não foi comprovada pelas Nações Unidas. Por outro lado, a América Latina, por ter sido historicamente subjugada pelo colonialismo, depois pelo neocolonialismo e, finalmente, pelo imperialismo, formou-se na região uma consciência de respeito ao direito internacional, que passou a ser visto como um mecanismo para a solução pacífica de controvérsias entre os Estados ${ }^{369}$.

\subsection{A crise brasileira e seu desdobramento geopolítico na América Latina}

Seria um equívoco pensar que a crise do Brasil é um assunto meramente doméstico, para Leonardo Boff, "está inserida no contexto internacional"370, o que Moniz Bandeira denominou "Segunda Guerra Fria" que envolve principalmente a balança de poder mundial entre os Estados Unidos e a China ${ }^{371}$. O governo estadounidense não admite perder a sua hegemonia na América Latina para os chineses que avançam na região em busca de novos mercados, especialmente o brasileiro ${ }^{372}$.

Em suas palavras:

Por trás do processo golpista no Brasil, que levou à ascensão do presidente interino Michel Temer no lugar da presidenta legítima Dilma Rousseff, há poderosos interesses dos Estados Unidos, para ampliar sua presença econômica e geopolítica na América do $\mathrm{Sul}^{373}$.

\footnotetext{
${ }^{368}$ MONIZ BANDEIRA, Luiz Alberto. A segunda Guerra Fria: geopolítica e dimensão estratégica dos Estados Unidos - Das rebeliões na Eurásia à África do Norte e ao Oriente Médio. 2. ed. Rio de Janeiro: Civilização Brasileira, 2014, p. 145.

${ }^{369}$ ARAUJO, Izan Reis de. Relações Internacionais na América Latina: do pan-americanismo aos nossos dias. In: PEREIRA, Ana Cristina Paulo; MENEZES, Wagner (Org.). Direito e Relações Internacionais na América Latina. Belo Horizonte: Arraes Editores, 2015, p. 384.

${ }^{370}$ BOFF, Leonardo. La crisis de Brasil y La geopolítica mundial. KontraInfo, 21 abr 2016. Disponível em: 〈http://kontrainfo.com/?p=1568>. Acesso em: 27 jun 2016.

${ }^{371}$ MONIZ BANDEIRA, Luiz Alberto. Op. cit., 2014.

372 NINIO, Marcelo. Brasil torna-se o primeiro destino de empréstimo chinês na América Latina. Folha de São Paulo, 11 fev. 2016. Disponível em: <http://www1.folha.uol.com.br/mercado/2016/02/1738777brasil-torna-se-primeiro-destino-de-emprestimo-chines-na-america-latina.shtml $>$. Acesso em: 27 jun. 2016.

373 MONIZ BANDEIRA, Luiz Alberto. Ponto de vista: Moniz Bandeira denuncia apoio dos EUA e o golpe no Brasil. Brasil Alemanha, 15 jun 2016. Disponível em:

<http://www.brasilalemanha.com.br/novo_site/noticia/ponto-de-vista-moniz-bandeira-denuncia-apoiodos-eua-a-golpe-no-brasil/8012>. Acesso em: 27 jun 2016.
} 
Além disso, para Moniz Bandeira, no plano internacional, o Brasil estava “contrariando Washington, com a criação do Banco do BRICS, uma alternativa ao FMI e ao Banco Mundial e o regime de partilha para o pré-sal, que conferiu papel estratégico à Petrobras, deslocando as petroleiras estrangeiras" ${ }^{\text {374 }}$. Portanto, não foi por acaso que a Petrobras e a presidenta Dilma Rousseff foram espionadas pela NSA, contradizendo o Pentágono que diz que não faz espionagem com interesses econômicos ${ }^{375}$. Esses são alguns indícios de que Washington, evidentemente, busca controlar o aparelho do Estado brasileiro para criar as condições favoráveis à acumulação lucrativa de capital pelos atores geoeconômicos internacionais. Para David Harvey, esse tipo de aparelho de Estado é conhecido como "Estado neoliberal", pois as suas ações refletem os interesses dos detentores de propriedade privada, dos negócios, das corporações monopolistas transnacionais e do capital financeiro ${ }^{376}$. De acordo com Noam Chomsky, os Estados Unidos estão mais preocupados em construir as condições mais favoráveis para os seus investimentos privados no exterior do que com o funcionamento do regime democrático nos países da América Latina ${ }^{377}$. A queda dos governos de Honduras, do Paraguai e do Brasil demonstra empiricamente essa tese.

No caso de Honduras, em 2009, embora o presidente Manuel Zelaya fosse do Partido Liberal (PL), o seu governo se afastou gradualmente das posições conservadoras do seu partido, no âmbito doméstico aumentou o salário mínimo e, no plano internacional, em 2008, o país associou-se ao Petrocaribe - acordo bilateral com a Venezuela para a compra de petróleo a preços subsidiados inferiores aos do mercado internacional. No mesmo ano, ingressou na Aliança Bolivariana das Américas (ALBA). A adesão do país ao grupo foi o estopim do golpe contra Zelaya ${ }^{378}$.

\footnotetext{
${ }^{374}$ MONIZ BANDEIRA: "Estados Unidos estão agindo para desestabilizar a América Latina". Opera Mundi. 23 mar. 2016. Acesso em: <http://operamundi.uol.com.br/dialogosdosul/moniz-bandeira-euaestao-agindo-para-desestabilizar-a-america-latina/23032016/>. Acesso em: 18 maio 20177

375 BRIDI, Sônia. Petrobras foi espionada pelos EUA, apotam documentos da NSA. Fantástico, 8 set. 2013. Disponível em: <http://g1.globo.com/fantastico/noticia/2013/09/petrobras-foi-espionada-pelos-euaapontam-documentos-da-nsa.html>. Acesso em: 29 jun. 2016.

${ }^{376}$ HARVEY, David. $O$ neoliberalismo: história e implicações. 5. ed. São Paulo: Edições Loyola, 2014, p. 17.

${ }^{377}$ CHOMSKY, Noam. Os EUA e a "pacificação presidencial" na América Latina. Esquerda.net, 16 jan. 2010. Disponível em: <http://www.esquerda.net/dossier/os-eua-e-pacifica\%C3\%A7\%C3\%A3opresidencial-na-am\%C3\%A9rica-latina $>$. Acesso em: 27 jun. 2016.

378 MARTIN, André Roberto. Sopa de letrinhas: Alba, Alca, Mercosul, Unasul, Can...Para onde vai a integração latino-americana? In: ARROYO, Mônica; ZUSMAN, Perla (Orgs.). Argentina e Brasil: possibilidades e obstáculos no processo de integração territorial. São Paulo: Humanitas, 2010, p. 39.
} 
O pretexto para o golpe foi a proposta de Zelaya de realizar um referendo sobre a possibilidade de convocar uma Assembleia Constituinte, e que permitisse a reeleição do chefe de Estado. Mas os golpistas alegaram duas questões: i) a Constituição do país proibia a consulta popular; ii) que ele visava a sua reeleição no próximo pleito, o que a Constituição também não permite.

Concernente à primeira questão, Ramón Barrios, professor de Direito Constitucional, em San Pedro Sula, em Honduras, lembra, "apesar de a Constituição hondurenha não permitir consultas populares, havia sido aprovada meses antes a Lei de Participação Cidadã, que possibilitaria a realização de um referendo" ${ }^{379}$. Com relação à segunda questão, a eventual eleição para a Constituinte seria em novembro, no mesmo dia do pleito para a sucessão presidencial, o que tornaria impossível sua reeleição. Em 28 de junho - data em que aconteceria o referendo - a Suprema Corte destituiu Zelaya. O presidente foi sequestrado ainda vestindo pijama, pelos militares, e levado para a Costa Rica. De acordo com ele, o avião que o levou à Costa Rica pousou antes em uma base aérea norte-americana próxima à capital hondurenha, Tegucigalpa. O próprio chefe do Comando Sul dos Estados Unidos, o general Douglas Fraser, confirmou o uso da base militar de Palmerola, no norte da capital hondurenha, Tegucigalpa, no golpe de Estado contra o presidente do país, Manuel Zelaya ${ }^{380}$.

O presidente do Congresso, Roberto Micheletti, também do PL, assumiu interinamente a Presidência. Curiosamente, o apoio e reconhecimento dos Estados Unidos ao processo eleitoral posterior que elegeu o novo governo "Pepe" Lobo, do Partido Nacional, rendeu ao Pentágono o uso da base aérea hondurenha de Palmerola. A posição dos Estados Unidos, nesse caso, ficou marcada pela ambiguidade, pois embora o presidente Barack Obama tenha classificado a ação em Honduras de golpe, a secretária de Estado americano, Hillary Clinton, evitou inicialmente assumir essa posição e não falou em exigir a volta de Zelaya. Diferentemente, o Brasil, a Argentina, a

\footnotetext{
379 GOMBATA, Marsílea. Honduras e Paraguai, motivos de inspiração. Carta Capital, 6 abr. 2016. Disponível em: 〈http://www.cartacapital.com.br/revista/895/honduras-e-paraguai-motivos-de-inspiracao $>$ Acesso em: 5 jul. 2016.

${ }^{380}$ FRANCE PRESSE. EUA admitem uso de base durante golpe hondurenho. Folha de São Paulo, 3 nov. 2009. Disponível em: <http://www1.folha.uol.com.br/mundo/2009/09/618851-eua-admitem-uso-de-basedurante-golpe-hondurenho.shtml>. Acesso em: 2 fev. 2017.
} 
Venezuela e tantos outros governos da região não reconheceram a legitimidade do processo eleitoral e do novo governo ${ }^{381}$.

Depois do golpe em Honduras, foi a vez de o Paraguai assistir à deposição do seu presidente legítimo Fernando Lugo, em junho de 2012. O golpe foi encoberto pelo impeachment - um processo com aparência legal - que foi aberto e votado em menos de 48 horas, dos quais Lugo só teve 16 horas para se defender das acusações genéricas feitas pela oposição. O motivo alegado para o impeachment é que Lugo não teve "competência" para administrar o país diante de uma crise no campo - na reintegração de posse de uma fazenda, em que morreram 11 camponeses e 6 policiais. A oposição exigia do presidente mais repressão contra os movimentos sociais dos camponeses. Não por acaso, o novo governo que assumiu o poder depois do golpe é dominado pelos latifundiários. Isso implicou na suspensão da participação do Paraguai em reuniões do MERCOSUL, pelos governos do Brasil, da Argentina, e do Uruguai. Lugo foi o primeiro presidente de esquerda do país que interrompeu uma hegemonia de 61 anos no poder do conservador Partido Colorado. A sua política no plano doméstico apoiava a reforma agrária por dentro das instituições ${ }^{382} \mathrm{e}$, na agenda internacional, havia uma ação concertada com os países da região pelo multilateralismo através do MERCOSUL, UNASUL e CELAC. Ainda nessa linha, documentos da embaixada americana em Assunção, vazados pelo Wikileaks, revelaram que o embaixador dos Estados Unidos informou a Washington, em março de 2009, que um golpe já estava sendo orquestrado pela direita contra Lugo, mediante parlamento ${ }^{383}$.

Uma análise, à luz desses "movimentos sincrônicos" 384 , aponta para uma desestabilização dos governos nacionais com viés progressista na América Latina, de modo que a crise que a região enfrenta, desde 2009, em Honduras, e 2012, no Paraguai,

\footnotetext{
${ }^{381}$ Hillary Clinton defiende su rol en el golpe de Estado en Honduras al ser cuestionada por Juan González. Democracy Now. Nova York, 13 abr. 2016. Disponível em:

$\langle$ https://www.democracynow.org/es/2016/4/13/hear_hillary_clinton_defend_her_role>. Acesso em: 18 maio 2017.

${ }^{382}$ CRISTALDO, Mariel. Lugo anuncia criação de conselho da reforma agrária no Paraguai. O Globo, 11 nov. 2008. Disponível em: 〈http://oglobo.globo.com/mundo/lugo-anuncia-criacao-de-conselho-dareforma-agraria-no-paraguai-3818005>. Acesso em: 04 jul. 2016.

383 Em 2009, EUA já previam golpe no Paraguai. Brasil 247, 25 jun. 2009. Disponível em: <http://www.brasil247.com/pt/247/mundo/66317/Em-2009-EUA-j\%C3\%A1-previam-golpe-no-

Paraguai.htm>. Acesso em: 04 jul. 2016.

${ }^{384}$ Movimentos sincrônicos são acontecimentos políticos que ocorrem simultaneamente entre os Estados num determinado contexto histórico, gerando um "efeito dominó". Esses movimentos sincrônicos são mostrados pela História de forma evidente: o movimento independentista na América Latina no século XIX, o golpe civil-militar nos países da região no contexto da Guerra Fria, o movimento pela redemocratização e tantos outros (MENEZES, Wagner. Op. cit., 2007, p. 85).
} 
é política, assim como também é política a causa da crise brasileira, cujos efeitos reverberam na economia que já apresenta a maior recessão da história do nosso país. Tanto isso é certo que no plano doméstico, a decisão do presidente da Câmara, Eduardo Cunha, de acolher o pedido de impeachment da presidente Dilma Rousseff, em 2 de dezembro de 2015, ocorreu somente poucas horas após a bancada do Partido dos Trabalhadores anunciar que iria votar a favor da cassação dele no Conselho de Ética. O deputado Eduardo Cunha estava sendo acusado de quebra de decoro parlamentar por mentir sobre a existência de contas bancárias no exterior em seu nome. Durante depoimento na Comissão Parlamentar de Inquérito (CPI) da Petrobras, em março de 2015, Cunha negara a existência de tais contas - o que acabaria sendo desmentido meses depois pela Procuradoria-Geral da República. Nesse contexto, a oposição, que foi derrotada no último pleito, em 2014, se aliou a Eduardo Cunha, formando um "centrão fisiológico" com uma estratégia bem clara de "quanto pior melhor" em relação à crise brasileira para justamente desgastar o governo Dilma perante a opinião pública, justificando, assim, sua queda via parlamento sob o pretexto de pedaladas fiscais.

No plano internacional, a tese de que a causa da crise brasileira é política também se confirma, pois, o Brasil é apenas mais um capítulo dentro da geoestratégia global de Washington que durante o governo Obama buscou ampliar a sua zona de influência em todo o continente americano, numa perspectiva geopolítica haushoferiana.

Será necessário fazer aqui uma breve digressão para apresentar o modelo geopolítico haushoferiano a fim de que se estabeleça a sua relação com o avanço da direita na América Latina capitaneada pelo governo estado-unidense.

Foi Karl Haushofer - geopolítico alemão, nascido em 1869 - quem propôs em 1937 uma regionalização do espaço mundial em quatro grandes unidades, denominada por ele de Pan-regiões, cada uma delas estaria articulada a três áreas (terra, capital e trabalho) que, por sua vez, desempenhariam diferentes funções no espaço de cada uma delas:

1) A terra seria uma área importante pelo fato de estar localizada numa região pouco povoada, logo, serviria de espaço reserva para uma futura ocupação e também seria utilizada como fonte de matérias-primas;

2) O capital é a área responsável pelo centro industrial dinâmico, galvanizador de regiões menos desenvolvidas; 
3) O trabalho é outra área cuja função principal seria a de fornecer mão de obra barata para a continuidade do processo de industrialização do centro, ou ainda, para ajudar o povoamento do espaço reserva.

Do ponto de vista da balança de poder, a teoria de Pan-regiões, de Haushofer, esboçava um mundo em equilíbrio, em que o sistema internacional estaria alinhado aos interesses nacionais das grandes potências sem superposição de nenhuma delas. Com isso, ele imaginava que a paz mundial estaria assegurada, não havendo mais a necessidade de os Estados entrarem em guerra. Contudo, essa teoria não conseguiu eliminar as assimetrias Norte-Sul, posto que todos os Estados que exerceriam a liderança das Pan-Regiões seriam as potências industriais do Hemisfério Norte. Segundo Haushofer, para construir uma “ordem mundial ideal”, era necessária uma aliança entre Alemanha, URSS e Japão em oposição à Inglaterra, à França e à China; e sem mexer com os Estados Unidos e sua hegemonia no novo continente ${ }^{385}$.

Como aponta André Martin:

Haushofer compreendia perfeitamente que o resgate do poderio alemão
dependia, portanto, de uma aliança com a Rússia, e dedicaria o principal dos
seus esforços para convencer seus compatriotas do acerto desta aliança.
Apesar de ideologicamente identificado com o pan-germanismo, ele teve o
mérito de renunciar às suas preferências, tendo em vista o apreço pela teoria
do Heartland de Mackinder, a qual lhe parecia uma explicação mais aderente
à realidade, do que aquela outra, também muito difundida à época, de que os
germânicos compunham uma "raça superior". Foi com base, e na convicção
de que a tendência histórica irreversível apontava para o declínio das velhas
potências colonialistas - Inglaterra e França, e em favor da ascensão das
novas potências industriais - Estados Unidos, Alemanha, Rússia e Japão que
ele desenvolveu sua teoria das "pan-regionen", substituindo o "povo", pelo
"espaço", como categoria unificadora dos grandes aglomerados
geopolíticos

Essa aliança costurada pela Alemanha consistiria na regionalização do espaço mundial em quatro grandes zonas de influências distribuídas para cada uma das novas potências industriais:

1) A zona de influência alemã, denominada de Euráfrica, que abarcaria a Europa exceto a Rússia, mais o Oriente Médio exceto o Irã, e todo o continente africano. Nessa perspectiva, a Alemanha seria o centro geoeconômico (capital), o mundo árabe entraria como espaço reserva e

${ }^{385}$ VESENTINI, José William. Op. cit., 2011, p.21.

${ }^{386}$ MARTIN, André Roberto. Op. cit., 2004, p. 25. 
fornecedor de petróleo (terra), e a África sub-saariana serviria de viveiro de mão de obra (trabalho);

2) A zona de influência da URSS, isto é, a Pan-Rússia estabelecia a Rússia europeia como o centro industrial (capital), a Sibéria a área-reserva (terra) e a Índia a fonte de mão de obra (trabalho);

3) A zona de influência japonesa, conhecida como Pan-Ásia ou a Esfera de Co-prosperidade asiática, nome dado pelos japoneses à vasta área em que o Japão representaria o centro industrial (capital), a Austrália serviria como área-reserva (terra), e a China como a fornecedora de mão de obra (trabalho);

4) A zona de influência dos Estados Unidos, chamada de Pan-América, reunido todo o continente americano, onde os Estados Unidos seriam a cabeça industrial (capital), o Canadá o espaço reserva (terra), e a América Latina o "viveiro" de mão de obra (trabalho).

De acordo com o geopolítico alemão, cada uma dessas quatro grandes unidades políticas teria uma grande potência como cabeça. Isso permitiria que as grandes potências centrais estivessem geopolíticamente satisfeitas, garantindo, assim, o equilíbrio de poder entre elas e, consequentemente, a paz e a segurança internacional, como se pode ver no mapa 21. 
Mapa 21: As Pan-regiões de Haushofer (1937)

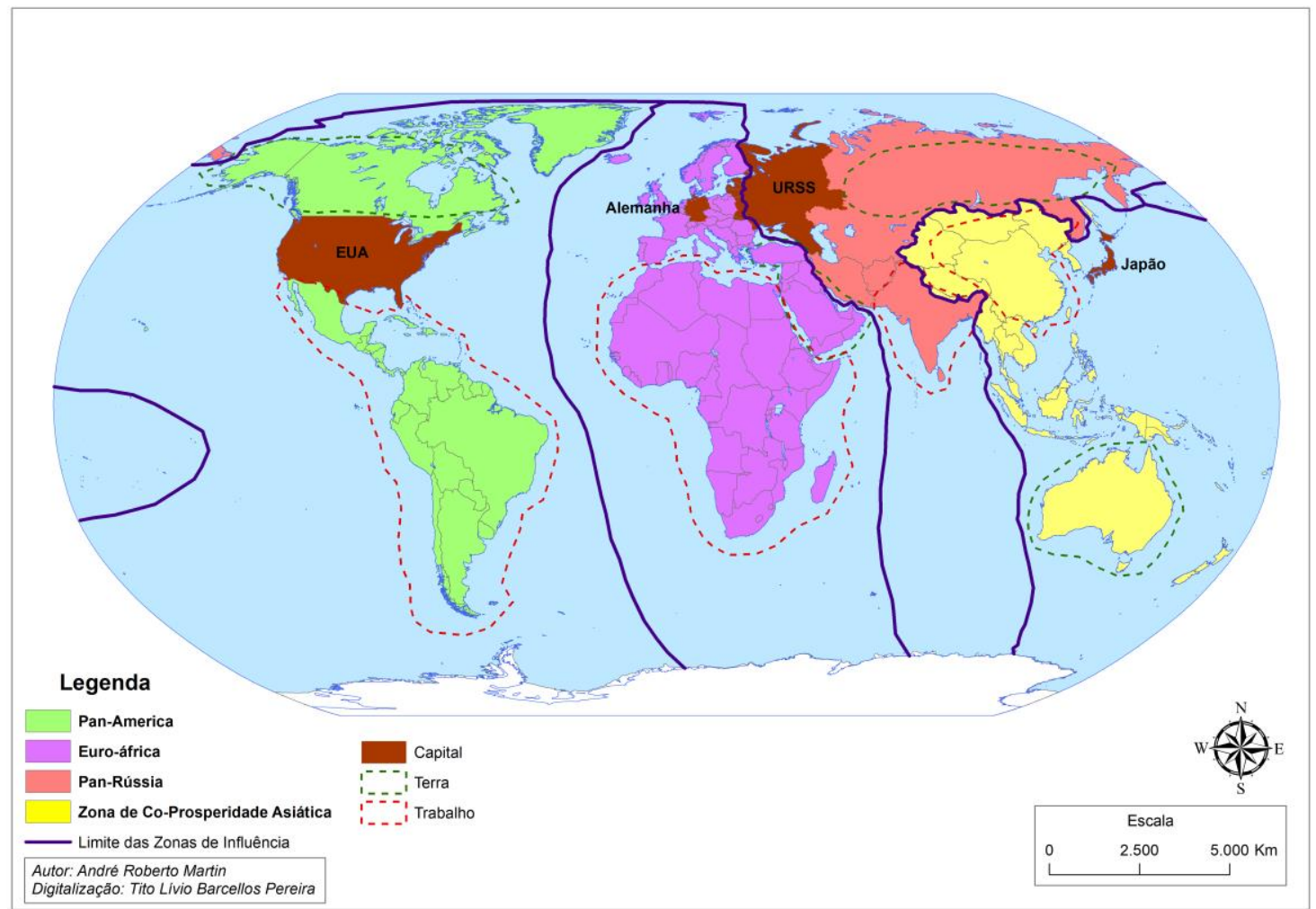

Diante dessa regionalização do espaço mundial, proposta por Haushofer, a questão que se coloca é a seguinte: é possível essa teoria atualmente? Como poderíamos pensá-la na contemporaneidade? Até que ponto os blocos econômicos podem exemplificar essa teoria?

No tocante à teoria das Pan-regiões, de Haushofer, fica evidente o papel da PanAmérica na geopolítica dos Estados Unidos na América Latina, pois do mesmo modo que a ALCA, a Aliança do Pacífico permitirá que Washington amplie a sua zona de influência em todo o continente americano, recompondo o "seu" mercado já ameaçado pela concorrência da China que desponta como um novo ator extra-regional. Desse modo, temendo perder espaço na América Latina para os chineses, os norte-americanos adotaram uma política externa de aproximação com os países da costa oeste da América do Sul - Colômbia, Peru, Chile - e trouxeram o México como cabeça de ponte para se projetarem na região.

Conforme assinalou Emir Sader:

A Aliança do Pacifico é a versão para o século XXI de outros projetos fracassados dos EUA para estender a todo o continente uma área de livre comércio. A primeira versão foi o Nafta - Área de Livre Comércio da America do Norte -, assinado entre os EUA, o Canadá e o México, em 1994, 
cujos planos iniciais eram ir incorporando a países do continente, conforme seus governos correspondessem às normas do Consenso de Washington ${ }^{387}$.

Nesse contexto, o próximo país que pretendia ingressar no NAFTA era o Chile, porém, no mesmo ano da assinatura do acordo, o México entrou numa crise econômica monumental, causada pela desvalorização do peso mexicano, em dezembro de 1994, conhecida como "efeito tequila", que refletiu fortemente na região, sendo a primeira crise do neoliberalismo na América Latina. Os Estados Unidos tiveram que mudar sua geoestratégia. Não havia mais como seguir convidando outros países latino-americanos a seguir o exemplo mexicano em sua opção, quando os primeiros resultados do novo bloco econômico já haviam sido negativos. Por isso mesmo, Washington elaborou uma nova versão da sua geoestratégia denominada ALCA. A proposta foi apresentada por George Bush, em 2001, na III Cúpula das Américas em Quebec, Canadá388. O alvo número um dessa ofensiva imperialista foi o MERCOSUL, que detém 10\% do mercado das Américas e dentro deste, o Brasil, cujo mercado equivalia a 2/3 do mercado da região correspondente ${ }^{389}$.

Conjunturalmente, na América do Sul, surge um movimento anti-imperialista por meio da ascensão de vários governos progressistas na região - Hugo Chávez na Venezuela (1998), Lula no Brasil (2003), Néstor Kirchner na Argentina (2003), Evo Morales na Bolívia (2006), Michele Bachelet no Chile (2006), Rafael Correa no Equador (2007), Fernando Lugo no Paraguai (2008) e José Mujica no Uruguai (2010) -, que ao invés de assinar Tratados de Livre Comércio com os Estados Unidos, privilegiaram os processos de integração regional - MERCOSUL, UNASUL, Banco do Sul, CDS, ALBA, CELAC, entre outros, portanto, pondo fim ao projeto ALCA. Diante desse novo cenário geopolítico regional, que se desenhava nos anos 2000, a correlação de forças ficou desfavorável para os Estados Unidos que, consequentemente, passaram a sofrer o maior isolamento da sua história na América Latina. Por essa razão, mudaram novamente a sua geoestratégia e passaram a costurar acordos bilaterais com os países da região que mantiveram a opção pelo livre comércio.

\footnotetext{
${ }^{387}$ SADER, Emir. A Aliança do Pacífico, uma alternativa? Carta Maior, 26 fev. 2014. Disponível em: $\langle$ http://www.cartamaior.com.br/?/Blog/Blog-do-Emir/A-Alianca-do-Pacifico-uma-alternativa-/2/30348 $>$. Acesso em: 17 jun. 2016.

${ }^{388}$ Bush quer fast-track para negociar Alca com latinos. BBC Brasil, 23 mar. 2001. Disponível em: $<$ http://www.bbc.com/portuguese/noticias/2001/010323 bush.shtml >. Acesso em: 21 dez. 2017.

389 SERRA, José. A Alca e a abertura. Folha de S. Paulo, 15 maio 1997. Disponível em: $\langle$ http://www1.folha.uol.com.br/fsp/dinheiro/fi150508.htm>. Acesso em: 11 jul. 2016.
} 
Atualmente, com a transferência da economia global para o Pacífico e a promessa de relações privilegiadas com mercados do Extremo Oriente com os quais tem estreitas relações, Washington atraiu para a sua zona de influência os governos conservadores da América do Sul através da Aliança do Pacífico. Esse novo bloco econômico visa estender a todo o continente americano uma zona de livre comércio em detrimento da integração sul-americana.

Como afirma o Embaixador Celso Amorim:

Ninguém vai dizer "vamos acabar com a Unasul, vamos acabar com o Mercosul". Eles vão dizer "vamos flexibilizar o Mercosul, vamos abrir a Unasul para entrar um ou outro país de fora da América do Sul, com perspectivas diferentes". "Vamos fazer uma associação com a Aliança para o Pacífico". É isso que vai acontecer ${ }^{390}$.

Através da Aliança do Pacífico, os Estados Unidos buscam não só retomar a ALCA, mas também destruir o processo de integração regional colocando o Brasil de volta em um cantinho pequeno no tabuleiro de xadrez da geopolítica global. Todavia, segundo Celso Amorim, "o problema é que o Brasil é grande demais, ele não consegue se esconder em um cantinho [...] o Brasil não pode se ausentar das questões mundiais, mas ser um construtor da agenda internacional" ${ }^{391}$.

A eleição de Donald Trump, em 2016, sinaliza o fim da unipolaridade ideológica americana e uma tendência de Nova Ordem Mundial pós-Globalização. Os Estados Unidos e Inglaterra, diferentemente do que todos imaginavam, estão priorizando suas políticas econômicas no fortalecimento do seu mercado interno, em detrimento do globalismo, que há muito tempo está debilitado devido à crise econômica mundial de 2008. Além disso, do ponto de vista da política externa, "as ideias de Samuel Huntington, não apenas sobre o choque das civilizações, mas sobre o declínio americano" 392 levaram o governo Trump a abandonar o universalismo (por exemplo, da “democracia como valor universal”), e em seu lugar passou a adotar uma realpolitik

\footnotetext{
${ }^{390}$ PUFF Jefferson. Impeachment é 'maquiavelismo de província', diz Celso Amorim. BBC Brasil, 15 abr. 2016. Disponível em:

$<$ http://www.bbc.com/portuguese/noticias/2016/04/160414_celso_amorim_ping_jp > Acesso em: 5 jul. 2016.

391 "O Brasil não pode se ausentar das questões mundiais", alerta Celso Amorim. Instituto Lula, 4 jul. 2016. Disponível em: <http://www.institutolula.org/o-brasil-nao-pode-se-ausentar-das-questoesmundiais-alerta-celso-amorim $>$. Acesso em: 5 jul. 2016.

392 ASHFORD, Emma M. Trump's Team Should Ditch the 'Clash of Civilizations'. The National Interest, 7 dez. 2016. Disponível em: <http://nationalinterest.org/blog/trumps-team-should-ditch-theclash-civilizations-18654>. Acesso em: 20 maio 2017.
} 
huntingtoniana baseada na multipolaridade entre os principais "Estados-núcleos"393 _ Estados Unidos, Rússia e China - que atuariam nesse novo cenário geopolítico mundial, visando mediar os conflitos existentes nas suas respectivas zonas de influências. A aproximação dos Estados Unidos e Rússia ${ }^{394}$, a Paz de Alepo na Síria ${ }^{395}$ e, a proposta chinesa para solucionar a tensão entre as duas Coreias e os Estados Unidos ${ }^{396}$, confirmam empiricamente essa tese.

Analisando a situação do Brasil, através da metodologia SWOT, nota-se que a ameaça do globalismo, preconizada pela candidata Hillary Clinton, não se concretizou, devido à eleição de Donald Trump. Por outro lado, surgiu uma nova oportunidade para o Itamaraty ampliar a projeção externa do Brasil para além do limite sul-americano. Para tanto, é necessário um saber geopolítico para ter condições de tirar proveito do desgaste nas relações Estados Unidos-México e resgatar a ALALC. Isso é condição sine qua non para retomar a proposta de integração da América Latina.

\subsection{Meridionalismo: um paradigma para a política externa brasileira?}

André Martin pensou na abordagem meridional de fazer política por uma questão geográfica, no sentido de geografizar a política e, ao mesmo tempo, politizar a geografia $^{397}$. A sua teoria traz a geografia para o centro dos debates políticos do nosso país, posto que estava até então relegada, num segundo plano. Ao contrário do que muitos ainda acreditam, que os geógrafos não têm habilidade para analisar a conjuntura política, o "meridionalismo" e a teoria do "sexto poder" demonstram que isso não é verdade. A genialidade do autor consiste em perceber que a posição (lage) do Brasil no

\footnotetext{
393 Os Estados-núcleos são aqueles Estados que exercem a liderança de uma determinada "civilização" no sentido huntingtoniano. Eles desempenham um papel vital para a mediação dos conflitos mundiais contemporâneos (HUNTINGTON, Samuel Phillips. O choque de civilizações e a recomposição da ordem mundial. Rio de Janeiro: Objetiva, 1997, p. 193-5).

${ }^{394}$ Lavrov se reúne com secretário de Estado dos EUA antes de encontro com Trump. G1, 10 maio 2017. Disponível em: <http://g1.globo.com/mundo/noticia/lavrov-se-reune-com-secretario-de-estado-dos-enaantes-de-encontro-com-trump.ghtml $>$. Acesso em: 22 maio 2017.

395 Vitória em Aleppo é crucial para estabelecer a paz na Síria, diz Irã. Agência Brasil, 5 jan. 2017. Disponível em: <http://agenciabrasil.ebc.com.br/internacional/noticia/2017-01/vitoria-em-aleppo-ecrucial-para-estabelecer-paz-na-siria-diz-ira>. Acesso em: 22 maio 2017.

${ }^{396}$ China propõe pacto aos EUA e à Coréia do Norte para evitar 'colisão frontal'. G1, 8 mar. 2017. Disponível em: <http://g1.globo.com/mundo/noticia/china-propoe-pacto-aos-eua-e-a-coreia-do-nortepara-evitar-colisao-frontal.ghtml>. Acesso em: 22 maio 2017.

397 MELHADO, Marília. Uma nova estratégia Sul-Sul. Forúm, outubro 2007. Disponível em: $<$ http://www.revistaforum.com.br/2012/02/09/uma-nova-estrategia-sul-sul-2/>. Acesso em: 25 maio 2017.
} 
mundo confere ao país três características geográficas distintas: o ocidentalismo, o tropicalismo e o meridionalismo.

O ocidentalismo porque o Brasil está 100\% no Hemisfério Ocidental Americano, o tropicalismo em razão de o país estar $92 \%$ dentro da zona intertropical, apenas uma pequena parte do território ao sul está de fora da linha do paralelo de Capricórnio. Finalmente, o meridionalismo pelo fato de $93 \%$ do território nacional se encontrar no Hemisfério $\mathrm{Sul}^{398}$. Ao analisar essas três características geográficas do nosso país, André Martin chegou à conclusão de que embora o termo "ocidental" traga uma ideia de vínculos com a Europa, a tropicalidade brasileira desmente um pouco essa tese. A própria sociologia e antropologia brasileira desenvolveram a questão da identidade nacional em cima da ideia do luso-tropicalismo ${ }^{399}$. Para Gilberto Freire, a tropicalidade foi condição para a colonização europeia, especialmente os portugueses que tinham uma singular predisposição para a "colonização híbrida e escravocrata dos trópicos" ${ }^{400}$, ainda nessa linha, Darcy Ribeiro salienta que os trópicos aparecem como um elemento da identidade nacional com sua população notadamente de matriz ameríndia e africana ${ }^{401}$. Por essa razão, o Brasil não é plenamente um país ocidental, por outro lado, temos uma população de origem europeia que também é considerável, o que não permite que sejamos considerados exclusivamente um país tropical.

De acordo com André Martin, essa dicotomia nos acompanha desde a origem da formação do Brasil, até hoje, em que o Estado metropolitano é ocidental, mas o povo colonial é tropical ${ }^{402}$. Então, diante das três características geográficas do nosso país, ele advoga que o meridionalismo é a que atende melhor ao caso brasileiro, em razão de ser uma alternativa dialética de superação dessa dicotomia, entre o "ocidentalismo" que

398 MELHADO, Marília. Uma nova estratégia Sul-Sul. Forúm, outubro 2007. Disponível em: <http://www.revistaforum.com.br/2012/02/09/uma-nova-estrategia-sul-sul-2/>. Acesso em: 25 maio 2017.

${ }^{399}$ O termo luso-tropicalismo foi desenvolvido por Gilberto Freire. Segundo ele, os portugueses tiveram que se adaptar às condições tropicais do Brasil, indo ao extremo de abandonar alguns valores e técnicas europeias e adotando, em seu lugar, técnicas tropicais. Por essa razão, Freire assinala que "a civilização que o Brasil está desenvolvendo nos trópicos não é puramente ocidental ou europeia.” (FREYRE, Gilberto. Novo Mundo nos Trópicos. 2. ed. Rio de Janeiro: Topbooks Univer Cidade, 2000, p. 61,161.

${ }^{400}$ FREYRE, Gilberto. Casa-grande \& Senzala: formação da família brasileira sob o regime da economia patriarcal. 34. ed. Rio de Janeiro: Record, 1998, p. 4-5.

${ }^{401}$ RIBEIRO, Darcy. O povo brasileiro: a formação e o sentido do Brasil. São Paulo: Companhia das Letras, 1995, p. 454-5.

402 Palestra do Prof. Dr. André Martin sobre "Meridionalismo: O Destino Manifesto Latino-americano" no Centro Russo-Brasileiro de Estudos da Multipolaridade (CEM), em 4 abr. 2017. Disponível em: <https://www.youtube.com/watch?v=dWP5XI9L8ag\&list=PLCDAlADJ4vG_83tkPHaIJyTPZfgHfpqFF> . Acesso em: 22 maio 2017. 
mantém o Brasil numa condição periférica em relação aos grandes centros industriais e o "tropicalismo" que faz um contraponto ao propor um "isolacionismo" de conteúdo terceiro-mundista ${ }^{403}$.

O conceito de "meridionalismo" não é algo novo, no sentido de que o termo já havia sido utilizado por Gramsci para discutir a questão meridional na Itália, ou seja, o atraso do Sul da Itália com uma economia voltada para o setor primário, enquanto que o Norte do país é industrializado ${ }^{404}$. Foi a partir daí que André Martin percebeu que também existe uma "condição meridional" mundial. Isto é, para ele, parte do Hemisfério Sul, embora ligada ao Hemisfério Norte por laços históricos, não está totalmente integrada ao "sistema- mundo" 405 , porque vive uma situação de periferia como era o caso do Sul da Itália perante o Norte.

Outro autor italiano que influenciou André Martin foi Norberto Bobbio, que diz que "o grande drama internacional é a disjuntiva entre um Hemisfério com excesso de poder e outro com excesso de impotência"406. Trazendo isso para o âmbito das relações internacionais, de fato, há uma assimetria no poder mundial, pois não há nenhum país do Hemisfério Sul no Conselho de Segurança das Nações Unidas e no G- $8^{407}$. Então, como responder a esse problema? Como esses países podem superar a "condição meridional" mundial de periferia e buscarem um novo patamar de inserção internacional?

Segundo André Martin, esse problema é, de certa forma, o mesmo que se defrontou Portugal no século XIV. O país estava numa condição periférica em relação à Castela, que estava no centro na Península Ibérica e, procurava, em seu proveito,

\footnotetext{
${ }^{403}$ MARTIN, André Roberto. Qual é nosso "Bloco"? O Brasil procura o seu lugar no mundo. In: SCARLATO, Francisco Capurano et al (Org.). O Novo Mapa do Mundo: globalização e espaço latinoamericano. 4. ed. São Paulo: Hucitec, 2002, p. 119.

${ }^{404}$ GRAMSCI, Antônio. A Questão Meridional. Rio de Janeiro: Paz e Terra, 1987.

${ }^{405}$ Immanuel Wallerstein definiu conceitualmente o Sistema-Mundo como sendo uma única estrutura integrada, econômica e politicamente, sob a lógica da acumulação capitalista. Esse sistema-mundo é regido por leis de movimento que levam à exploração das economias pobres pelas economias centrais (NOGUEIRA, João Pontes; MESSARI, Nizar. Op. cit., 2005, p, 123). Nesse esquema, os países pobres estariam em desvantagem, porque enquanto exportavam produtos primários para os grandes centros industriais, estes, por sua vez, exportavam produtos manufaturados. Assim, o desnível tecnológico entre as nações da periferia e da semiperiferia em relação às potências centrais seria o ponto nevrálgico no processo de atraso econômico e social e na manutenção desse status quo (PENNAFORTE, Charles. Análise dos Sistemas-Mundo: uma pequena introdução ao pensamento de Immanuel Wallerstein. Rio de Janeiro: Cenegri edições, 2011, p. 38).

406 MELHADO, Marília. Uma nova estratégia Sul-Sul. Forúm, outubro 2007. Disponível em: $\langle$ http://www.revistaforum.com.br/2012/02/09/uma-nova-estrategia-sul-sul-2/>. Acesso em: 25 maio 2017.

${ }^{407}$ MARTIN, André Roberto. Op. cit., 2007, p. 112.
} 
unificar toda a região. Mas, dentro da sistemática geopolítica henriquina, Portugal tinha um projeto de inserção internacional baseado na "diretriz meridionalista" que consistia em chegar às Índias pelo Hemisfério Sul, contornando a costa da África (mapas 1 e 2).

Do mesmo modo que a "diretriz meridionalista portuguesa" tirou Portugal da sua condição periférica para torná-lo o centro do mundo, despontando como a primeira potência global, a "teoria meridionalista brasileira" representa para o Brasil e os demais países da América Latina uma alternativa de superação de sua "condição meridional" mundial. Esse é o desafio que enfrentaremos nos próximos anos, salienta André Martin, "globalismo ou meridionalismo, sermos a periferia dos Estados Unidos ou o centro do Hemisfério Sul?" 408 .

Para a chancelaria brasileira, isso não é algo novo, o próprio Rui Barbosa quando chefiou a delegação brasileira na Conferência de Paz, em Haia (Holanda), em 1907, defendeu o princípio da igualdade dos Estados e o fim do colonialismo não só na América Latina, mas também em todo o Hemisfério Sul.

De acordo com André Martin, o meridionalismo e a teoria do sexto poder ${ }^{409}$ advogam o reconhecimento da existência de um sexto "player global" na disputa pelo poder mundial, o qual seria representado pelo "veto compartilhado" brasileiro-indiano no Conselho de Segurança ${ }^{410}$. Segundo ele, esse arranjo geopolítico-diplomático poderia se chamar "IBASA" na medida em que a Austrália aceitasse entrar no IBAS ${ }^{411}$. Lembrando que isso não é uma política externa terceiro-mundista, porque no conceito de "terceiro mundo" está a China e não a Austrália, mas no conceito de "bloco meridional”, está a Austrália e não está a China, conforme demonstra o mapa 22.

\footnotetext{
${ }^{408}$ Idem. Op. cit., 2004, p. 46.

${ }^{409}$ A ideia do sexto "player global" surgiu na teoria do "sexto poder" de André Martin. Segundo o autor, depois que a Pentarquia redefiniu o equilíbrio de poder entre as cinco grandes potências europeias (França, Inglaterra, Prússia, Rússia e Áustria), Karl Marx disse, mas esqueceram o sexto poder? Isto é, o proletariado, que havia demonstrado sua força com a Primavera dos Povos, em 1848. Trazendo isso para o âmbito das Relações internacionais contemporâneas, o autor advoga que as cinco potências são: Estados Unidos, União Europeia, Rússia, China e Japão e o sexto poder são as potências meridionalistas representadas no bloco "IBASA".

${ }^{410}$ MARTIN, André Roberto. Op. cit., 2007, p. 112.

${ }^{411}$ Ibidem, p. 112.
} 
Mapa 22: O Meridionalismo e a Teoria do Sexto Poder de André Martin

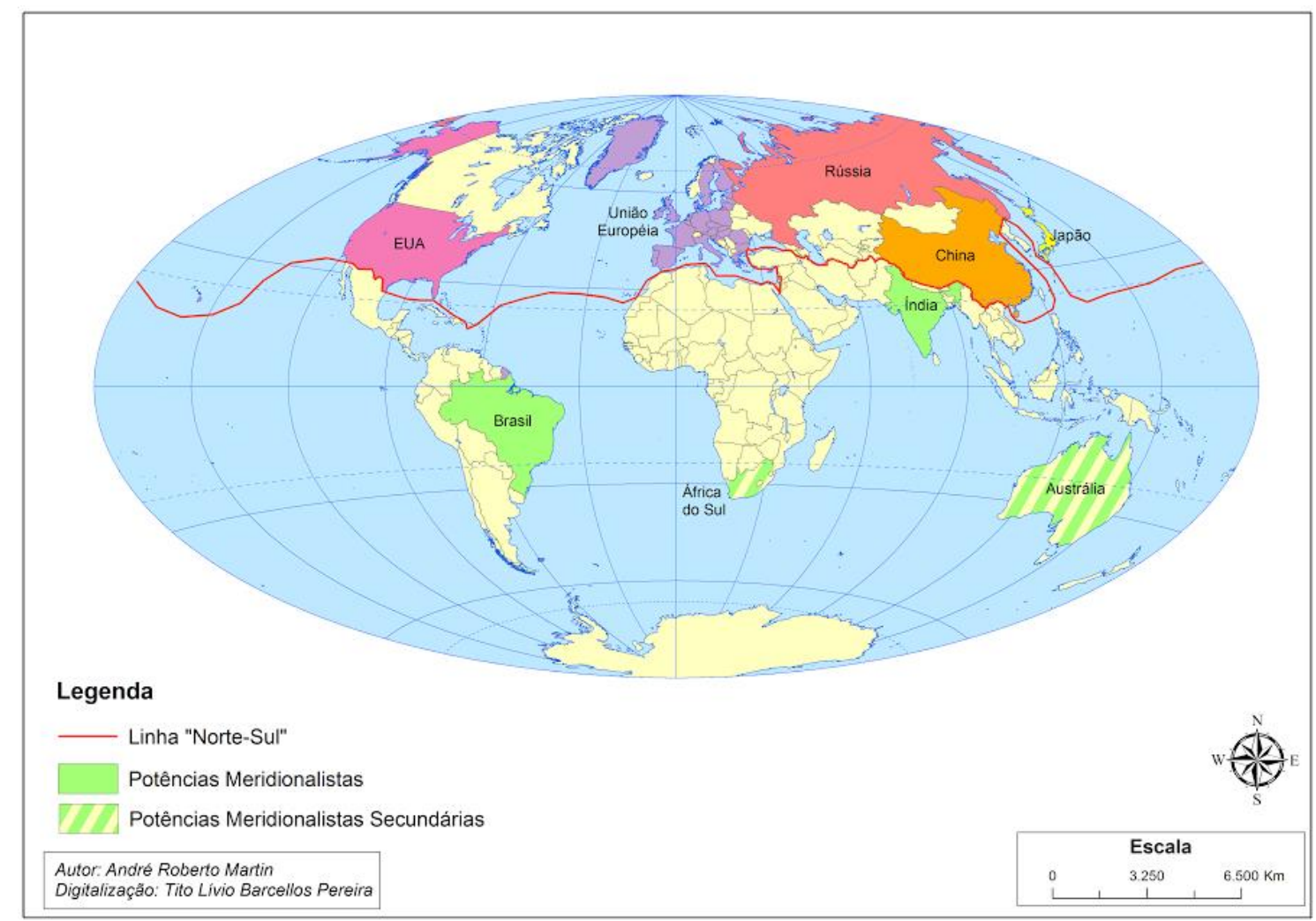

Ao inverter a projeção azimutal de Mackinder para o Hemisfério Sul, o autor identifica a África do Sul, a Índia e a Austrália, como potências regionais que poderiam estender a projeção geopolítica do Brasil para muito além da América do Sul. Ou seja, o Brasil deixaria de ser apenas uma potência terrestre e passaria a ser uma potência anfíbia. É por isso mesmo que o meridionalismo e a teoria do sexto poder são tão atuais e significativas, sobretudo no contexto da América Latina, que coloca o nosso país como o seu legítimo representante no bloco meridionalista com o objetivo de romper o cerco sul-americano de Spykman e, consequentemente, transpor a barreira da presença estado-unidense na América Central e do Caribe. Esse seria o ponto nevrálgico de um constructo de integração regional latino-americana numa perspectiva geopolítica. Nesse sentido, o bloco meridionalista, com o apoio da América Latina, permitirá que o Estado brasileiro tenha um maior protagonismo nos grandes foros internacionais - Organização das Nações Unidas (ONU) e Organização Mundial do Comércio (OMC) - e, por conseguinte, haverá uma maior possibilidade de construirmos uma Nova Ordem Mundial pós-globalização e que seja multipolar. Isso é condição sine qua non para que no futuro a humanidade seja mais justa e democrática. 


\section{CONSIDERAÇÕES FINAIS}

A presente dissertação possibilitou uma análise geopolítica da projeção do Brasil na América Latina e dos desafios contemporâneos da integração regional sul-americana. Além disso, também permitiu realizar um debate teórico sobre a relação entre os conceitos de "América do Sul" e "América Latina", com vistas a desvelar qual deve ser o espaço privilegiado de atuação da política externa brasileira que melhor corresponda com as potencialidades geopolíticas do país. Com essa abordagem, o trabalho buscou resgatar a importância do pensamento geopolítico brasileiro como um instrumento teórico-metodológico relevante para a formulação da política externa do país.

De um modo geral, os documentos do Itamaraty, em anexo, baseados nos discursos do presidente Lula, do chanceler Celso Amorim e do secretário-geral do Ministério das Relações Exteriores, Samuel Pinheiro Guimarães, corroboram a hipótese de que o recorte espacial sul-americano, adotado pelo Itamaraty, é decorrente do projeto brasileiro de ser uma potência regional com vistas a obter um maior protagonismo nos processos decisórios internacionais. Contudo, a presente dissertação demonstrou que somente a América Latina, do ponto de vista geopolítico, conta com excedentes de recursos suficientes para gerar poder em escala mundial.

No primeiro capítulo da pesquisa nos debruçamos em estudar, inicialmente, a diferença entre a Geografia Política e a Geopolítica, e constatamos que enquanto a primeira assumiu um sentido de neutralidade científica, a segunda está voltada para a transformação. Nessa nova "ciência", destaca-se Friedrich Ratzel, que além de desempenhar um papel fundamental no processo de sistematização da geografia moderna também é o pai da geopolítica. Dentre suas inúmeras contribuições, consideramos as categorias "espaço" (raum), "posição" (lage) e "Estado" decisivas para instrumentalizar este trabalho. Embora tenha passado mais de um século de sua morte, é possível afirmar que suas teorias e conceitos continuam vivos e apresentam relevantes contribuições teóricas para a análise do cenário geopolítico mundial contemporâneo.

Ainda nesse capítulo, realizamos uma análise do pensamento geopolítico brasileiro sobre a América do Sul, tentamos demonstrar que a região é o espaço (raum) no qual se formou o núcleo geohistórico do Brasil e suas fronteiras atuais. Ficou demonstrado também que a dinâmica da política sul-americana é decorrente do conceito de "instabilidade geográfica", de Mario Travassos, isto é, da oscilação de certos 
"territórios não controlados" entre países vizinhos ou mesmo uma potência extraregional que possuem características fisiográficas que os circundam. Travassos citou três exemplos de "instabilidade geográfica" na América do Sul: a Bolívia, a Colômbia e o Uruguai.

Percebemos neste trabalho que, embora os países da América Central e do Caribe sejam vistos pelo Itamaraty como um conjunto de Estados satélites dos Estados Unidos, que atuariam como um estado-tampão entre Washington e Brasília para evitar, pelo menos, uma ameaça potencial ao Brasil e assegurar o equilíbrio de poder regional, o estudo demonstrou que devido à "instabilidade geográfica" da América do Sul, os Estados Unidos estão presentes na região independentemente da diplomacia brasileira adotar o recorte sul-americano ou não. O Comando Sul, a Quarta Esquadra e as bases militares americanas, instaladas na região, comprovam, empiricamente, essa tese. Especialmente na costa noroeste da América do Sul, que se mostra acessível a influências externas via canal do Panamá, permitindo a projeção externa da potência hegemônica em todo o continente americano.

Outra grande contribuição de Travassos para o campo de estudo da geopolítica consiste na aplicação da teoria do pivot geográfico, formulado por Mackinder, na América do Sul para analisar a balança de poder regional. A pesquisa também demonstrou que a geopolítica pré-esguiana influenciou o governo Vargas, especialmente o modelo travassiano que foi implementado na política territorial do país, em particular no Plano Geral de Viação Nacional, de 1934, que articulou os corredores de exportação norte e leste, e também as comunicações do Brasil longitudinal com o Brasil Platino e Amazônico.

No segundo capítulo, demonstramos que há na literatura uma discussão polêmica em torno do conceito de "América Latina". Apesar de não haver um consenso sobre a origem do termo, ou seja, quem foi o primeiro autor a utilizar a expressão "América Latina", o que se pode perceber é um compartilhamento entre as versões geopolítica e literária e que, sem dúvida nenhuma, Chevalier foi um grande difusor e defensor do termo.

O estudo também constatou que na arquitetura contemporânea de segurança da América Latina há forças centrípetas e centrífugas presentes na região. As primeiras representadas pelas instituições de segurança como a UNASUL e a CELAC, que foram influenciadas por Simon Bolívar e visam à integração regional, por outro lado, as forças 
centrífugas são identificadas com os Estados Unidos, devido a sua ingerência na região desde a Doutrina Monroe e que, atualmente, com o seu projeto monopolar visa impor ao mundo o seu American way of life, demonstrado pelo mapa 17.

No terceiro capítulo, analisamos o processo de integração regional na agenda do Itamaraty e entendemos que a inserção do Brasil na América Latina se deu no marco da Operação Pan-Americana, proposta pelo presidente Juscelino Kubistchek. Mas, a partir de 1993, houve uma inflexão na política externa brasileira, devido a adesão do México ao NAFTA no ano anterior, levando o Itamaraty a abandonar o conceito de "América Latina" e, em seu lugar, o Estado brasileiro passou a defender uma política voltada para a "América do Sul”, que começou a se desenhar com o projeto ALCSA e essa diretriz foi mantida ao longo das próximas décadas, como uma das linhas de continuidade da política externa brasileira, especialmente no governo Lula, que a materializou com a criação da UNASUL, em 2008. Contudo, do ponto de vista geopolítico, a utilização do recorte espacial sul-americano resultará na fragmentação da América espanhola e obviamente criará um "vácuo de poder" na região que poderá ser ocupado por uma potência extra-regional, leia-se, Estados Unidos ou China.

Utilizamos ainda nessa pesquisa a teoria do poder perceptível do Professor Ray Cline e aperfeiçoada por Meira Mattos, para demonstrar que a América Latina possui um excedente de recursos suficiente para gerar poder em escala global, sobretudo em um mundo em que se valorizam tanto os dados estatísticos para a formação de blocos econômicos.

Ao analisarmos a crise política brasileira e seu desdobramento geopolítico na América Latina, procuramos demonstrar com a metodologia SWOT que a ameaça do globalismo, preconizada pela candidata Hillary Clinton, não se concretizou, devido à eleição de Donald Trump, em 2016. Nesse contexto, surgiu uma nova oportunidade para o Brasil e o México retomarem as suas relações, no sentido de juntos promoverem a integração regional da América Latina. Portanto, o Itamaraty tem uma nova chance de projetar o Brasil para além do limite sul-americano. Contudo, é necessário resgatar a velha geopolítica se quiser ter condições de tirar proveito do desgaste nas relações Estados Unidos-México e retomar a ALALC.

Ao final, o trabalho contribuiu para a compreensão do papel do Estado brasileiro na América Latina demonstrando que a região deve ser o espaço privilegiado da política externa brasileira, sobretudo no contexto do "meridionalismo" e da teoria do "sexto 
poder", de André Martin, que advoga um sexto player global em torno de um bloco no Hemisfério Sul capitaneado pelo Brasil, África do Sul, Índia e Austrália que atuariam como representantes dos seus países vizinhos num cenário geopolítico multipolar. Mas, para isso, é necessário um projeto brasileiro de potência mundial, ou caso contrário, assinalam Bertha Becker e Cláudio Egler, continuaremos "como uma potência regional, restrita em termos estratégicos à América do Sul” ${ }^{\prime 412}$ e sem protagonismo no tabuleiro de xadrez da geopolítica global.

Como sugestão de continuidade de pesquisa, entendemos que será relevante analisar quais ações da chancelaria brasileira influenciam na formação e no desenvolvimento de um "bloco meridional" com o objetivo de buscar uma maior inserção internacional do Brasil. As aporias da política externa brasileira sobretudo nos últimos anos estariam, portanto, relacionadas a esta imprecisão geopolítica.

412 BECKER, Bertha Koiffmann; EGLER Claudio Antonio Goncalves. Brasil: Uma Nova Potência Regional na Economia-Mundo. Rio de Janeiro: Bertrand Brasil, 1993, p. 167. 


\section{REFERÊNCIAS}

ALBUQUERQUE, Edu Silvestre de. Geopolítica do Brasil: a construção da soberania nacional. São Paulo: Atual, 2006.

80 anos da obra projeção continental do Brasil, de Mário Travassos. Revista do Departamento de Geografia, São Paulo, v. 29, p. 59-78, jun. 2015. Disponível em: 〈http://revistas.usp.br/rdg/article/view/102081>. Acesso em: 02 nov. 2016.

ALEIXO, José Carlos Bradi. Visão e atuação internacional de Simon Bolívar. Revista de informação Legislativa. Brasília, v. 20, n. 80, p. 25-52, out./dez. 1983.

O Brasil e o Congresso Anfictiônico do Panamá. Revista Brasileira de Política Internacional. Brasília: FUNAG, ano 43, n. 2, p. 170-191, 2000.

ALMEIDA, Paulo Roberto de. O Mercosul no contexto regional e internacional. São Paulo: Aduaneiras, 1993.

- Sovereignty and Regional Integration in Latin America: A Political Conundrum? Contexo Internacional, v. 35, n. 2, p. 471-495, 2013.

O desenvolvimento do Mercosul: progressos e limitações. Revista Espaço da Sophia, n. 43, jul/set, 2011. Disponível em: <http://docplayer.com.br/4177752-Odesenvolvimento-do-mercosul-progressos-e-limitacoes.html>. Acesso em: 1 mar. 2017.

AMORIM, Celso. Breves narrativas diplomáticas. São Paulo: Benvirá, 2013.

ANDRADE, Manuel Correia de. Geopolítica do Brasil. São Paulo: Ática, 1995.

ANSELMO, Rita de Cássia Martins de Souza; BRAY, Silvio Carlos. Geografia e Geopolítica na formação nacional brasileira: Everardo Adolpho Backheuser. In: GERARDI, Lúcia Helena de Oliveira; Mendes, Iandara Alves (Org.). Do natural, do Social e de suas Interações: Visões Geográficas. 1. ed. Rio Claro - SP: Programa de Pós-Graduação em Geografia UNESP/ AGETEO, 2002, p. 109-119.

ARANA, Marie. Bolívar: o libertador da América. São Paulo: Três Estrelas, 2015.

ARAUJO, Assilio Luiz Zanella; FERRARI FILHO, Fernando. O processo de integração na América do Sul: da ALALC à UNASUL. Ensayos de Economía, Medellín, Colômbia, v. 25, n. 46, p. 99-120, 2015.

ARAUJO, Izan Reis de. Relações Internacionais na América Latina: do panamericanismo aos nossos dias. In: PEREIRA, Ana Cristina Paulo; MENEZES, Wagner (Org.). Direito e Relações Internacionais na América Latina. Belo Horizonte: Arraes Editores, 2015, p. 384-393.

ARAVENA, Francisco Rojas. Las Medidas de Confianza Mutua y de Seguridad: perspectivas desde Chile. Fasoc, v. 17, n. 1 - n. 2, p. 32- 43, ene./jun., 2002. 
ARGENTINA. Ministerio de Defensa. Libro Blanco de La Defensa. Buenos Aires, 2010.

AYERBE, Luis Fernando. Estados Unidos e América Latina: a construção da hegemonia. São Paulo: Editora Unesp, 2002.

BACKHEUSER, Everardo. Geopolítica e Geografia Política. Revista Brasileira de Geografia. Rio de Janeiro: IBGE, n. 1, p. 21-38, jan./mar., 1942.

BARACE, Mariano Garcia. La expresión América latina no fue creada por Francisco Bilbao. In: Posición Iberoamericana. Especiais intelectuales del Rio de la Plata. Buenos Aires, Argentina. Edición dez. 2011.

BARRIOS, Miguel Ángel. Diccionário latinoamericano de seguridad y geopolítica. Buenos Aires: Biblos, 2009.

BECKER, Bertha Koiffmann. A Geografia e o Resgate da Geopolítica. Revista Brasileira de Geografia, Rio de Janeiro, v. 50, n. 2, número especial, p. 99-125, 1988.

BECKER, Bertha Koiffmann; EGLER Claudio Antonio Goncalves. Brasil: Uma Nova Potência Regional na Economia-Mundo. Rio de Janeiro: Bertrand Brasil, 1993.

BECKER, Howard Saul. Outsiders: Estudos de sociologia do desvio. Rio de Janeiro: Zahar. 2008.

BOLÍVAR, Simon. Carta da Jamaica. Toronto: Ed. Elaleph, 1999. Disponível em: <http://www.cpihts.com/PDF/Simon\%20Bolivar.pdf>. Acesso em: 5 maio 2016.

BRASIL. Constituição (1988). Constituição da República Federativa do Brasil. 35. ed. Brasília: Câmara dos Deputados, Edições Câmara, 2012.

Ministério da Defesa. Livro Branco de Defesa Nacional. Brasília, 2012.

Ministério das Relações Exteriores. Estatísticas para o estudo das relações internacionais: maio de 2016. Brasília: Instituto de Pesquisa de Relações Internacionais/ FUNAG, 2016.

BUENO, Clodoaldo; RAMANZINI JÚNIOR, Haroldo; VIGEVANI, Tullo. Uma Perspectiva de Longo Período sobre a Integração Latino-americana Vista pelo Brasil. Contexto internacional, Rio de Janeiro, v. 36, n.2, p. 549-583, dez. 2014.

CARTA DA ORGANIZAÇÃO DOS ESTADOS AMERICANOS. In: SALIBA, Aziz Tuffi. (Org.). Legislação de direito internacional. 2. ed. São Paulo: Rideel, 2007, p. 679-700.

CARTA DAS NAÇÕES UNIDAS. In: SALIBA, Aziz Tuffi. (Org.). Legislação de direito internacional. 2. ed. São Paulo: Rideel, 2007, p. 700-718. 
CARVALHO, Elyseo de. O factor geographico na política brasileira. Rio de Janeiro: S.A. Monitor Mercantil, 1921.

CASTRO, Therezinha de. Atlas-texto de geopolítica do Brasil. Rio de Janeiro: Capemi Editora, 1981.

José Bonifácio e a unidade nacional. Rio de Janeiro: Bibliex, 1984.

Nossa América: Geopolítica comparada. Rio de Janeiro: Bibliex, 1994.

Do Infante a Tordesilhas - Sistemática Geopolítica. Revista do Instituto

Geográfico Histórico Militar do Brasil, Rio de Janeiro, n. 81, p. 53-71, 1995.

CERVO, Amado Luiz. Relações Internacionais da América Latina: velhos e novos paradigmas. Brasília: IBRI, 2001.

2008.

Inserção Internacional: formação dos conceitos brasileiros. São Paulo: Saraiva,

CERVO, Amado Luiz; BUENO, Clodoaldo. História da política exterior do Brasil. 3. ed. Brasília: Editora Universidade de Brasília, 2008.

CLINE, Ray Steiner. World Power Assessment - A Calculus of Strategic Drift, 1975. In: MATTOS, Carlos de Meira. A Geopolítica e as projeção de poder. Rio de Janeiro: Biblioteca do Exército, 1977.

CORTESÃO, Jaime. Os descobrimentos portugueses. Lisboa: Livros Horizonte, v. II, 1975.

COSTA, Alex Vander Lima. Integração Sul-americana: um teorema sem fim. Monografia apresentada ao Departamento de Estudos da Escola Superior de Guerra como requisito à obtenção do diploma do Curso de Altos Estudos de Política e Estratégia (CAEPE). Rio de Janeiro, 2012.

COSTA, Darc Antonio da Luz. Um Discurso de Estratégia Nacional: A Cooperação Sul-Americana como Caminho para a Inserção Internacional do Brasil. Tese de Doutorado apresentada ao Programa de Pós-Graduação em Engenharia de Produção da Universidade Federal do Rio de Janeiro. Rio de Janeiro, 1999.

Segurança e Defesa: uma única visão abaixo do Equador. In: GUIMARÃES, Samuel Pinheiro; LLADÓS, José Maria (Org.). Perspectivas Brasil e Argentina. Rio de Janeiro: IPRI, 1999, v. 2, p. 35-69.

COSTA, Mariete Pinheiro. O Parlamento e o Soldado da Borracha no Limiar da II Guerra Mundial. Monografia apresentada ao Curso de Especialização em Instituições e Processos Políticos do Legislativo - Câmara dos Deputados, Centro de Formação, Treinamento e Aperfeiçoamento. Brasília, 2007. 
COSTA, Wanderley Messias da. O Estado e as políticas territoriais no Brasil. São Paulo: Contexto, 1988.

Projeção do Brasil no Atlântico Sul: Geopolítica e Estratégia. Revista USP, São Paulo, n. 95, p. 9-22, 2012,

Geografia Política e Geopolítica: Discursos sobre o Território e o Poder. 2. ed. São Paulo: Edusp, 2013.

COUTO E SILVA, Golbery do. Geopolítica do Brasil. Rio de Janeiro: José Olympio Editora, 1967.

COX, Robert W. Gramsci, Hegemonia e Relações internacionais: um ensaio sobre método. In: GILL, Stephen. (Org.). Gramsci: materialismo histórico e relações internacionais. Rio de Janeiro: Editora UFRJ, 2007, p. 101-123.

DEUTSCH, Karl Wolfgang et al. Political Community and the North Atlantic Area: International Organization in the Light of Historical Experience. Princeton: Princeton University, 1957.

DIAS, Demosthenes de Oliveira. Formação Territorial do Brasil: Origem e Evolução. Rio de Janeiro: Gráfica Olímpica, 1956.

DOMINGUEZ, Jorge. "International cooperation in Latin America: the design of regional institutions by slow accretion". In: AMITAV, Acharya; ALASTAIR, Iain Johnston. (Org.). Crafting Cooperation: Regional International Institutions in Comparative Perspective. New York, Cambridge University Press, 2007, p. 83-128.

DORATIOTO, Francisco Fernando Monteoliva. Guerra do Paraguai. In: MAGNOLI, Demétrio. (Org.). História das Guerras. 1. ed. São Paulo: Contexto, 2006, p. 253-285

; VIDIGAL, Carlos Eduardo. História das Relações Internacionais do Brasil. 1. ed. São Paulo: Saraiva, 2014.

ESPIELL, Héctor Gros. La doctrine du Droit International en Amérique Latine avant la première conférence panaméricaine. (Washington, 1889). Journal of the History of International. Law, v. 3, p. 1-17, 2001.

FOHLEN, Claude. O faroeste. São Paulo: Companhia das Letras, 1989.

FRAGA, Jorge Alberto. La Argentina y el Atlântico Sur: conflictos y objetivos. Buenos Aires: Editora Pleamar y Instituto de Publicaciones Navales del Centro Naval. 1983.

FREIRE, Gilberto. Casa-grande \& Senzala: formação da família brasileira sob o regime da economia patriarcal. 34. ed. Rio de Janeiro: Record, 1998.

2000.

Novo Mundo nos Trópicos. 2. ed. Rio de Janeiro: Topbooks Univer Cidade, 
- Americanidade e latinidade da América Latina e outros textos afins. Organizado por Edson Nery da Fonseca. Brasília: Ed. da Universidade de Brasília, 2003.

GRAMSCI, Antônio. A Questão Meridional. Rio de Janeiro: Paz e Terra, 1987.

GUIMARÃES, Samuel Pinheiro. Quinhentos anos de periferia: uma contribuição ao estudo da política internacional. 3. ed. Rio de Janeiro: Contraponto, 2001.

Desafios brasileiros na era de gigantes. Rio de Janeiro: Contraponto, 2005.

. O mundo multipolar e a integração sul-americana. Comunicação \& Política, Rio de Janeiro: Cebela, v. 25, n. 3, p. 169-189, set./dez., 2007.

HARVEY, David. O neoliberalismo: história e implicações. 5. ed. São Paulo: Edições Loyola, 2014.

HERZ, John. "Idealist Internationalism and the Security Dilemma". World Politics, v. 2, n. 2, p. 157-180, 1950.

HOBSBAWM, Eric John. A era dos impérios, 1875-1914. 18. ed. Rio de Janeiro: Paz e Terra, 2014.

HUNTINGTON, Samuel Phillips. The Clash of Civilizations? Foreign Affairs, 1993.

. O choque de civilizações e a recomposição da ordem mundial. Rio de Janeiro:

Objetiva, 1997.

KISSINGER, Henry. Diplomacia. São Paulo: Saraiva, 2012.

Ordem mundial. Rio de Janeiro: Objetiva, 2015.

LENIN, Vladimir Llitch. O Programa Agrário da Social-Democracia na Primeira Revolução Russa de 1905-1907. São Paulo: Livraria Editora Ciências Humanas, 1980.

2012.

Imperialismo, estágio superior do capitalismo. São Paulo: Expressão Popular,

LESSA, Antônio Carlos. Há cinquenta anos a Operação Pan-Americana. Revista Brasileira de Política Internacional. Brasília, v. 51, n. 2, p. 5-7, jul./dez. 2008.

LIGIERO, Luiz Fernando. A autonomia na política externa brasileira: a política externa independente e o pragmatismo responsável: momentos diferentes, políticas semelhantes? Brasília: Fundação Alexandre de Gusmão, 2011.

MACKINDER, Halford John. The Geographical Pivot of History. The Geographical Journal, London, v. 23, n. 4, p. 421-437, apr., 1904.

Democratic Ideals and Reality: a study in the politics of reconstruction. London: Constable and Company Ltd, 1919. 
The Round World and the Winning of The Peace. Foreign Affairs, New York, v. 21, n. 4, p. 595-605, jul., 1943.

MACMILLAN, Margaret. A Primeira Guerra Mundial. São Pulo: Globo Livros, 2014.

MAFRA, Roberto Machado de Oliveira. Geopolítica: introdução ao estudo. São Paulo: Sicureza, 2006.

MARTIN, André Roberto. Fronteiras e nações. São Paulo: Contexto, 1992.

As fronteiras internas e a "questão regional" do Brasil. Tese de Doutorado apresentada ao Departamento de Geografia da Faculdade de Filosofia, Letras e Ciências Humanas da Universidade de São Paulo. São Paulo, 1993.

O Brasil procura seu lugar no mundo. In: SCARLATO, Francisco Capurano et al (Org.). O novo mapa do mundo: globalização e espaço latino-americano. 4. ed. São Paulo: Hucitec, 2002, p. 105-121.

. Qual é nosso "Bloco"? O Brasil procura o seu lugar no mundo. In: SCARLATO, Francisco Capurano et al (Org.). O Novo Mapa do Mundo: Globalização e espaço latino-americano. 4. ed. São Paulo: Hucitec, 2002, p. 105-121.

- Geopolítica e Poder Mundial. In: CASTELAR, Sônia Maria Vanzella; MARTINS, Elvio Rodrigues (Org.). Geografia. São Paulo: Secretaria de Estado da Educação, Universidade de São Paulo, 2004.

Brasil, Geopolítica e Poder Mundial: o anti-Golbery. Tese de Livre-Docência apresentada ao Departamento de Geografia da Faculdade de Filosofia, Letras e Ciências Humanas da Universidade de São Paulo. São Paulo, 2007.

Sopa de letrinhas: Alba, Alca, Mercosul, Unasul, Can...Para onde vai a integração latino-americana? In: ARROYO, Mônica; ZUSMAN, Perla (Org.). Argentina e Brasil: possibilidades e obstáculos no processo de integração territorial. São Paulo: Humanitas, 2010, p. 37- 57.

MARX, Karl; ENGELS, Friedrich. Contribuição para uma história da América Latina. São Paulo: Edições Populares, 1982.

MATTOS, Carlos de Meira. A geopolítica e as projeções do poder. Rio de Janeiro: Biblioteca do Exército, 1977.

.Uma Geopolítica Pan-Amazônica. Rio de Janeiro: Bibliex, 1980.

1990.

Geopolítica e teoria de fronteiras: fronteiras do Brasil. Rio de Janeiro: Bibliex,

. Geopolítica e Modernidade. In: MATTOS, Carlos de Meira. Geopolítica. Rio de Janeiro: Editora FGV, v. 3, 2011. 
Projeção Mundial do Brasil. In: MATTOS, Carlos de Meira. Geopolítica. Rio de Janeiro: Editora FGV, v. 1, p. 31- 82, 2011.

MELLO, Leonel Itaussu Almeida. A Geopolítica do Brasil e a Bacia do Prata. Dissertação de Mestrado em Ciência Política apresentada ao Departamento de Ciências Sociais da Pontifícia Universidade Católica de São Paulo. São Paulo: PUC, 1987. 69, dez., 1994.

A geopolítica e o poder terrestre revisitada. Lua Nova, São Paulo, n. 34, p. 55Quem tem medo da geopolítica? 2. ed. São Paulo: Hucitec - Instituto Leonel Itaussu, 2015.

MENEZES, Wagner. Mercado Comum do Sul (MERCOSUL). In: MERCADANTE, Araminta de Azevedo; CELLI JUNIOR, Umberto; ARAUJO, Leandro Rocha de (Org.). Blocos Econômicos e Integração na América Latina, África e Ásia. Curitiba: Juruá, 2006, v. 1, p. 137-159.

A contribuição da América Latina para o Direito Internacional: o Princípio da Solidariedade. Tese de Doutorado apresentada ao Programa de Pós-Graduação em Integração da América Latina (PROLAM) da Universidade de São Paulo. São Paulo, 2007.

Derecho Internacional en América Latina. Brasília: FUNAG, 2010.

MILANI, Carlos Roberto Sanchez et al. Atlas da política externa brasileira. Rio de Janeiro: EdUERJ; Buenos Aires: Clasco, 2015.

MIYAMOTO, Shiguenoli. O Pensamento Geopolítico Brasileiro (1920-1980). Dissertação de Mestrado apresentada ao Departamento de Ciências Sociais (área de Ciência Política) da Faculdade de Filosofia, Letras e Ciências Humanas da Universidade de São Paulo. São Paulo, 1981.

A geopolítica e o Brasil potência. Marília: UNESP, Faculdade de Educação, Filosofia, Ciências Sociais e da Documentação. 1985. (Séries Monográficas. Relações Internacionais, 4).

MONIZ BANDEIRA, Luiz Alberto. Presença dos Estados Unidos no Brasil: dois séculos de história. 2. ed. Rio de Janeiro: Civilização Brasileira, 1978.

Entrevista.

Seria difícil para Chávez sustentar qualquer guerra. A tarde, Bahia, 8 jul. 2007.

A Importância Geopolítica da América do Sul na Estratégia dos Estados Unidos. Revista da Escola Superior de Guerra, v. 14, p. 7-35, 2008.

Brasil, Argentina e Estados Unidos: conflito e integração na América do Sul (da Tríplice Aliança ao Mercosul), 1870-2007. 3. ed. Rio de Janeiro: Civilização Brasileira, 2010. 
A expansão do Brasil e a formação dos Estados na Bacia do Prata: Argentina, Uruguai e Paraguai (da colonização à Guerra da Tríplice Aliança). 4. ed. Rio de Janeiro: Civilização Brasileira, 2012.

Formação do império americano: da guerra contra a Espanha à guerra no Iraque. 4. ed. Rio de Janeiro: Civilização Brasileira, 2014.

A segunda Guerra Fria: geopolítica e dimensão estratégica dos Estados Unidos - Das rebeliões na Eurásia à África do Norte e ao Oriente Médio. 2. ed. Rio de Janeiro: Civilização Brasileira, 2014.

MONTESQUIEU. Charles de. Do Espírito das Leis. São Paulo: Editora Martin Claret, 2005.

MORAES, Antonio Carlos Robert. Introdução. In: MORAES, Antonio Carlos Robert (Org.) e FERNANDES, Florestan (Coord.). Ratzel. São Paulo: Ed. Ática, 1990.

Geografia: pequena história crítica. 21. ed. São Paulo: Annablume, 2007.

MORSE, Richard McGee. O espelho de Próspero: cultura e idéias nas Américas. São Paulo, Companhia Das Letras, 1988.

MORGENTHAU, Hans Joachim. A Política entre as nações: a luta pelo poder e pela paz. São Paulo: IOESP-UnB-IPRI, 2003.

NEVES, André Luiz Varella. Governo George Walker Bush (2001-2004): Uma análise geopolítica das Guerras do Afeganistão e do Iraque. Tese de Doutorado apresentada ao Departamento de Ciência Política da Faculdade de Filosofia, Letras e Ciências Humanas da Universidade de São Paulo. São Paulo, 2010.

NOGUEIRA, João pontes; MESSSARI, Nizar. Teoria das relações internacionais: correntes e debates. Rio de Janeiro: Elsevier, 2005.

NOUR, Soraya. À paz perpétua de Kant: filosofia do direito internacional e das relações internacionais. São Paulo: Martins Fontes. 2004, p. 125.

NYE, Joseph. O Paradoxo do Poder Americano. São Paulo: Editora da Unesp, 2002.

OLIVEIRA, Ariovaldo Umbelino de. A Mundialização do Capitalismo e a Geopolítica mundial no Fim do Século XX. In: ROSS, Jurandyr Luciano Sanches. (Org.). Geografia do Brasil. 6. ed. São Paulo: EDUSP, 2011.

OLIVEIRA, Fernando. A Arte da Guerra do Mar: estratégia e guerra naval no tempo dos descobrimentos. Lisboa/Portugal: Editora 70, 2008.

ORGANIZAÇÃO DOS ESTADOS AMERICANOS (OEA). Relatório da Presidência da Quinta Conferência de Ministros da Defesa das Américas. Washington, D.C., 2003. 
PADULA, Raphael. Da IIRSA ao COSIPLAN da UNASUL: a integração de infraestrutura na América do Sul nos anos 2000 e suas perspectivas de mudança. In: NETO, Walter Antonio Desiderá (Org.). O Brasil e novas dimensões da integração regional. 1. ed. Brasília: IPEA, 2014, p. 291-352.

PALMER, Alan Warwick. Bismarck. Brasília: Editora UNB, 1982.

PARKER, Geoffrey. Atlas da História do Mundo. 4. ed. São Paulo: Folha de São Paulo, 1995.

PENNAFORTE, Charles. Análise dos Sistemas-Mundo: uma pequena introdução ao pensamento de Immanuel Wallerstein. Rio de Janeiro: Cenegri edições, 2011.

PENHA, Eli Alves. A criação do IBGE no contexto da criação do Estado Novo. Rio de Janeiro: IBGE, Centro de Documentação e Disseminação de Informações, 1993.

Somos todos americanos? Unidade e Diversidade Regional nas Américas. Cadernos Prolam/USP, São Paulo, v. 14, n. 26, p. 63-76, 2015.

PIERI, Vitor Stuart Gabriel de; TELES; Reinaldo Miranda de Sá; OLIVEIRA, Fabiana de. Breve História da Integração Latino-americana: entre o Monroísmo e Bolivarianismo. Rio de Janeiro: CENEGRI, 2015.

PINHEIRO, Letícia de Abreu. Política externa brasileira, 1889-2002. Rio de Janeiro: Jorge Zahar Ed., 2004.

PREBISCH, Raúl. O desenvolvimento econômico da América Latina e alguns de seus problemas principais. In: BIELCHOSWSKY, Ricardo (Org.). Cinquenta anos de pensamento na CEPAL. Rio de Janeiro: Record, 2000, v. 1.

RAFFESTIN, Claude. Por uma geografia do poder. Tradução Maria Cecília França. São Paulo: Ática, 1993.

RATZEL, Friedrich. O Solo, a Sociedade e o Estado. Revista do Departamento de Geografia, São Paulo, v. 2, p. 93-101, nov. 1983. Disponível em: <http://revistas.usp.br/rdg/article/view/47081>. Acesso em: 26 jul. 2016.

As leis do crescimento espacial dos Estados. In: MORAES, Antonio Carlos Robert (Org.); FERNANDES, Florestan (Coord.). Ratzel. São Paulo: Ed. Ática, 1984.

RIBEIRO, Darcy. O povo brasileiro: a formação e o sentido do Brasil. São Paulo: Companhia das Letras, 1995.

RICARDO, David. Princípios de Economia Política e Tributação. Tradução Paulo Henrique Ribeiro Sandroni. São Paulo: Nova Cultural, 1996. Original inglês.

RIO-BRANCO, Miguel Paranhos de. Alexandre de Gusmão e o Tratado de 1750. Brasília: Mec os Cadernos de Cultura, 1953. 
RIVAROLA, Andrés. Prólogo. In: BARRIOS, Miguel Ángel (Org.). Diccionário latinoamericano de seguridad y geopolítica. Buenos Aires: Biblos, 2009.

ROUSSEAU, Jean-Jaques. O contrato social. Porto Alegre: L\&PM, 2009.

SANTOS, Luís Cláudio Villafañe Gomes. A América do Sul no discurso diplomático brasileiro. Brasília: Funag, 2014.

SANTOS, Milton. A natureza do Espaço: Técnica e Tempo, Razão e Emoção. 4 ed. São Paulo: Editora da Universidade de São Paulo, 2014.

Por uma outra globalização: do pensamento único à consciência universal. 24 ed. Rio de Janeiro: Record, 2015.

SCALZARETTO, Reinaldo; MAGNOLI, Demétrio. Atlas Geopolítico. São Paulo: Editora Scipione, 1996.

SCHWARTZ, Jorge. Abaixo Tordesilhas. Revista Estudos Avançados, S. Paulo, IEA USP, n. 17, 1993.

SILVA, Alexandra de Mello e. A política externa de $J K$ : a Operação Pan-Americana. Rio de Janeiro: CPDOC, 1992.

SILVA, Leonardo Dantas. Tordesilhas: A divisão do Brasil antes de Pedro Álvares Cabral. In: ANDRADE, Manuel Correia de (Org.). Tordesilhas: um marco geopolítico. Recife: Funjaj, Ed. Massangana, 1997.

SILVA, Luis Inácio Lula da; AMORIM, Celso; GUIMARAES, Samuel Pinheiro. A Política Externa do Brasil. Brasília: IPRI/Funag, 2003.

SILVEIRA, Maria Laura. Argentina: Território e globalização. São Paulo: Brasiliense. 2003.

SOARES, Teixeira. História da Formação das Fronteiras do Brasil. Rio de Janeiro: Biblex, 1973.

TAVARES, Rubens Diniz. Políticas Externas de Argentina e Brasil: regionalismo e projetos de Integração na América do Sul 2003 a 2013. Dissertação de Mestrado apresentada ao Programa de Pós-Graduação em Integração da América Latina (PROLAM) da Universidade de São Paulo. São Paulo, 2015.

TOSTA, Octavio. Teorias geopolíticas. Rio de Janeiro: Biblex, 1984.

TRATADO de União Liga e Confederação Perpétua, 1826. In: MENEZES, Wagner. $A$ contribuição da América Latina para o Direito Internacional: o Princípio da Solidariedade. Tese de Doutorado apresentada ao Programa de Pós-Graduação em Integração da América Latina (PROLAM) da Universidade de São Paulo. São Paulo, 2007. 
TRATADO Interamericano de Assistência Recíproca. In: SALIBA, Aziz Tuffi. (Org.). Legislação de direito internacional. 2. ed. São Paulo: Rideel, 2007, p. 850-854.

TRAVASSOS, Mario. Projeção Continental do Brasil. 3. ed. São Paulo: Editora Nacional, 1938.

Introdução à Geografia das Comunicações Brasileiras (Ensaio). Rio de Janeiro: José Olympio, 1942.

U.S. SOUTHER COMMAND. A Pictorial History. Disponível em: 〈http://www.southcom.mil/50/Pages/Main.aspx >. Acesso em: 8 jan. 2016.

VLACH, Vânia Rubia Farias. Estudo preliminar acerca dos geopolíticos militares brasileiros. Revista Terra Brasilis. São Paulo,v. 4, n. 5, 2003.

VESENTINI, José William. Novas geopoíticas. 5. ed. São Paulo: Contexto, 2011. VIEIRA, Friederick Brum. Modelo travassiano: a geopolítica que guia o Brasil na ditadura e na democracia. Rio de Janeiro: Milênio, 2008.

VISENTINI, Paulo Gilberto Fagundes. Política exterior e desenvolvimento (19511964): o nacionalismo e a política externa independente. Revista Brasileira de História. São Paulo: ANPUH/Marco Zero, v. 14, n. 27, p. 99-111, 1994.

WEBER, Marx. Ciência e Política: Duas Vocações. São Paulo: Editora Martin Claret, 2006.

WEIFFEN, Brigitte. The Inter-American Security System: Changes and Challenges. Carta Internacional, São Paulo, v. 5, n 1, p. 21-37, 2010.

WEINBERG, Albert Katz. Manifest Destiny: A Study of Nationalist Expansionism in American History. In: CARVALHO, Maria Lucia Brant de. Das Terras dos Índios a Índios sem Terras. O Estado e os Guarani do Oco'y. Violência, Silêncio e Luta. Tese de Doutorado apresentada ao Departamento de Geografia da Faculdade de Filosofia, Letras e Ciências Humanas da Universidade de São Paulo. São Paulo, 2013.

WHITE HOUSE. National Strategy for Combating Terrorism. Washington D.C., 2003.

YEPES, Jesus Maria. Del Congresso do Panamá a la Conferência de Caracas. Caracas: Oficina Central de Informação, 1976. 


\section{ANEXOS}




\begin{abstract}
ANEXOS
Anexo A Discurso do Senhor Presidente da República, Luiz Inácio Lula da Silva, na Sessão de Posse, no Congresso Nacional, em Brasília - 2003

Anexo B Discurso do Embaixador Celso Amorim por ocasião da Transmissão do Cargo de Ministro de Estado das Relações Exteriores, em Brasília - 2003

Anexo C Discurso do Embaixador Samuel Pinheiro Guimarães por ocasião da Transmissão do Cargo de Secretário-Geral das Relações Exteriores, em Brasília - 2003
\end{abstract}




\author{
ANEXO A \\ DISCURSO DO SENHOR PRESIDENTE DA REPÚBLICA, \\ LUIZ INÁCIO LULA DA SILVA, NA SESSÃO DE POSSE, NO CONGRESSO \\ NACIONAL, EM BRASÍLIA
}

Brasília, $1^{\circ}$ de janeiro de 2003.

Exmos. Srs. Chefes de Estado e de Governo; senhoras e senhores; visitantes e chefes das missões especiais estrangeiras; Exmo. Sr. Presidente do Congresso Nacional Senador Ramez Tebet;

Exmo. Sr. Vice-Presidente, da República, José Alencar; Exmo. Sr. Presidente da Câmara dos Deputados, Deputado Efraim Morais, Exmo. Sr. Presidente do Supremo Tribunal Federal, Ministro Marco Aurélio Mendes de Faria Mello; Sras. e Srs. Ministros e Ministras de Estado; Sras. e Srs. Parlamentares, senhoras e senhores presentes a este ato de posse.

"Mudança"; esta é a palavra-chave, esta foi a grande mensagem da sociedade brasileira nas eleições de outubro. A esperança finalmente venceu o medo, e a sociedade brasileira decidiu que estava na hora de trilhar novos caminhos.

Diante do esgotamento de um modelo que, em vez de gerar crescimento, produziu estagnação, desemprego e fome; diante do fracasso de uma cultura do individualismo, do egoísmo, da indiferença perante o próximo, da desintegração das famílias e das comunidades.

Diante das ameaças à soberania nacional, da precariedade avassaladora da segurança pública, do desrespeito aos mais velhos e do desalento dos mais jovens; diante do impasse econômico, social e moral do País, a sociedade brasileira escolheu mudar e começou, ela mesma, a promover a mudança necessária.

Foi para isso que o povo brasileiro me elegeu Presidente da República: para mudar. Este foi o sentido de cada voto dado a mim e ao meu bravo companheiro José 
Alencar. E eu estou aqui, neste dia sonhado por tantas gerações de lutadores que vieram antes de nós, para reafirmar os meus compromissos mais profundos e essenciais, para reiterar a todo cidadão e cidadã do meu País o significado de cada palavra dita na campanha, para imprimir à mudança um caráter de intensidade prática, para dizer que chegou a hora de transformar o Brasil naquela nação com a qual a gente sempre sonhou: uma nação soberana, digna, consciente da própria importância no cenário internacional e, ao mesmo tempo, capaz de abrigar, acolher e tratar com justiça todos os seus filhos.

Vamos mudar, sim. Mudar com coragem e cuidado, humildade e ousadia, mudar tendo consciência de que a mudança é um processo gradativo e continuado, não um simples ato de vontade, não um arroubo voluntarista. Mudança por meio do diálogo e da negociação, sem atropelos ou precipitações, para que o resultado seja consistente e duradouro.

O Brasil é um País imenso, um continente de alta complexidade humana, ecológica e social, com quase 175 milhões de habitantes. Não podemos deixá-lo seguir à deriva, ao sabor dos ventos, carente de um verdadeiro projeto de desenvolvimento nacional e de um planejamento de fato estratégico. Se queremos transformá-lo, a fim de vivermos em uma Nação em que todos possam andar de cabeça erguida, teremos de exercer quotidianamente duas virtudes: a paciência e a perseverança.

Teremos que manter sob controle as nossas muitas e legítimas ansiedades sociais, para que elas possam ser atendidas no ritmo adequado e no momento justo; teremos que pisar na estrada com os olhos abertos e caminhar com os passos pensados, precisos e sólidos, pelo simples motivo de que ninguém pode colher os frutos antes de plantar as árvores.

Mas começaremos a mudar já, pois como diz a sabedoria popular, uma longa caminhada começa pelos primeiros passos.

Este é um País extraordinário. Da Amazônia ao Rio Grande do Sul, em meio a populações praieiras, sertanejas e ribeirinhas, o que vejo em todo lugar é um povo maduro, calejado e otimista. Um povo que não deixa nunca de ser novo e jovem, um povo que sabe o que é sofrer, mas sabe também o que é alegria, que confia em si mesmo e em suas próprias forças. Creio num futuro grandioso para o Brasil, porque a nossa alegria é maior do que a nossa dor, a nossa força é maior do que a nossa miséria, a nossa esperança é maior do que o nosso medo. 
O povo brasileiro, tanto em sua história mais antiga, quanto na mais recente, tem dado provas incontestáveis de sua grandeza e generosidade, provas de sua capacidade de mobilizar a energia nacional em grandes momentos cívicos; e eu desejo, antes de qualquer outra coisa, convocar o meu povo, justamente, para um grande mutirão cívico, para um mutirão nacional contra a fome.

Num país que conta com tantas terras férteis e com tanta gente que quer trabalhar, não deveria haver razão alguma para se falar em fome. No entanto, milhões de brasileiros, no campo e na cidade, nas zonas rurais mais desamparadas e nas periferias urbanas, estão, neste momento, sem ter o que comer. Sobrevivem milagrosamente abaixo da linha da pobreza, quando não morrem de miséria, mendigando um pedaço de pão.

Essa é uma história antiga. O Brasil conheceu a riqueza dos engenhos e das plantações de cana-de-açúcar nos primeiros tempos coloniais, mas não venceu a fome; proclamou a independência nacional e aboliu a escravidão, mas não venceu a fome; conheceu a riqueza das jazidas de ouro, em Minas Gerais, e da produção de café, no Vale do Paraíba, mas não venceu a fome; industrializou-se e forjou um notável e diversificado parque produtivo, mas não venceu a fome. Isso não pode continuar assim.

Enquanto houver um irmão brasileiro ou uma irmã brasileira passando fome, teremos motivo de sobra para nos cobrirmos de vergonha.

Por isso, defini entre as prioridades de meu Governo um programa de segurança alimentar que leva o nome de "Fome Zero". Como disse em meu primeiro pronunciamento após a eleição, se, ao final do meu mandato, todos os brasileiros, tiverem a possibilidade de tomar café da manhã, almoçar e jantar, terei cumprido a missão da minha vida.

É por isso que hoje conclamo: Vamos acabar com a fome em nosso País. Transformemos o fim da fome em uma grande causa nacional, como foram no passado a criação da Petrobras e a memorável luta pela redemocratização do País. Essa é uma causa que pode e deve ser de todos, sem distinção de classe, partido, ideologia. Em face do clamor dos que padecem o flagelo da fome, deve prevalecer o imperativo ético de somar forças, capacidades e instrumentos para defender o que é mais sagrado: a dignidade humana.

Para isso, será também imprescindível fazer uma reforma agrária pacífica, organizada e planejada. 
Vamos garantir acesso à terra para quem quer trabalhar, não apenas por uma questão de justiça social, mas para que os campos do Brasil produzam mais e tragam mais alimentos para a mesa de todos nós, tragam trigo, tragam soja, tragam farinha, tragam frutos, tragam o nosso feijão com arroz.

Para que o homem do campo recupere sua dignidade sabendo que, ao se levantar com o nascer do sol, cada movimento de sua enxada ou do seu trator irá contribuir para o bem-estar dos brasileiros do campo e da cidade, vamos incrementar também a agricultura familiar, o cooperativismo, as formas de economia solidária. Elas são perfeitamente compatíveis com o nosso vigoroso apoio à pecuária e à agricultura empresarial, à agroindústria e ao agronegócio. São, na verdade, complementares tanto na dimensão econômica quanto social. Temos de nos orgulhar de todos esses bens que produzimos e comercializamos.

A reforma agrária será feita em terras ociosas, nos milhões de hectares hoje disponíveis para a chegada de famílias e de sementes, que brotarão viçosas com linhas de crédito e assistência técnica e científica. Faremos isso sem afetar de modo algum as terras que produzem, porque as terras produtivas se justificam por si mesmas e serão estimuladas a produzir sempre mais, a exemplo da gigantesca montanha de grãos que colhemos a cada ano.

Hoje, tantas e tantas áreas do País estão devidamente ocupadas, as plantações espalham-se a perder de vista, há locais em que alcançamos produtividade maior do que a da Austrália e a dos Estados Unidos. Temos que cuidar bem - muito bem - deste imenso patrimônio produtivo brasileiro. Por outro lado, é absolutamente necessário que o País volte a crescer, gerando empregos e distribuindo renda.

Quero reafirmar aqui o meu compromisso com a produção, com os brasileiros e brasileiras, que querem trabalhar e viver dignamente do fruto do seu trabalho. Disse e repito: criar empregos será a minha obsessão. Vamos dar ênfase especial ao Projeto Primeiro Emprego, voltado para criar oportunidades aos jovens, que hoje encontram tremenda dificuldade em se inserir no mercado de trabalho. Nesse sentido, trabalharemos para superar nossas vulnerabilidades atuais e criar condições macroeconômicas favoráveis à retomada do crescimento sustentado para a qual a estabilidade e a gestão responsável das finanças públicas são valores essenciais. 
Para avançar nessa direção, além de travar combate implacável à inflação, precisaremos exportar mais, agregando valor aos nossos produtos e atuando, com energia e criatividade, nos solos internacionais do comércio globalizado.

Da mesma forma, é necessário incrementar - e muito - o mercado interno, fortalecendo as pequenas e microempresas. É necessário também investir em capacitação tecnológica e infraestrutura voltada para o escoamento da produção.

Para repor o Brasil no caminho do crescimento, que gere os postos de trabalho tão necessários, carecemos de um autêntico pacto social pela mudança e de uma aliança que entrelace objetivamente o trabalho e o capital produtivo, geradores da riqueza fundamental da Nação, de modo a que o Brasil supere a estagnação atual e para que o País volte a navegar no mar aberto do desenvolvimento econômico e social.

O pacto social será, igualmente, decisivo para viabilizar as reformas que a sociedade brasileira reclama e que eu me comprometi a fazer: a reforma da Previdência, reforma tributária, reforma política e da legislação trabalhista, além da própria reforma agrária. Esse conjunto de reformas vai impulsionar um novo ciclo do desenvolvimento nacional.

Instrumento fundamental desse pacto pela mudança será o Conselho Nacional de Desenvolvimento Econômico e Social que pretendo instalar já a partir de janeiro, reunindo empresários, trabalhadores e lideranças dos diferentes segmentos da sociedade civil.

Estamos em um momento particularmente propício para isso. Um momento raro da vida de um povo. Um momento em que o Presidente da República tem consigo, ao seu lado, a vontade nacional. O empresariado, os partidos políticos, as Forças Armadas e os trabalhadores estão unidos. Os homens, as mulheres, os mais velhos, os mais jovens, estão irmanados em um mesmo propósito de contribuir para que o País cumpra o seu destino histórico de prosperidade e justiça.

Além do apoio da imensa maioria das organizações e dos movimentos sociais, contamos também com a adesão entusiasmada de milhões de brasileiros e brasileiras que querem participar dessa cruzada pela retomada pelo crescimento contra a fome, o desemprego e a desigualdade social. Trata-se de uma poderosa energia solidária que a nossa campanha despertou e que não podemos e não vamos desperdiçar. Uma energia ético-política extraordinária que nos empenharemos para que se encontre canais de expressão em nosso Governo. 
Por tudo isso, acredito no pacto social. Com esse mesmo espírito constituí o meu Ministério com alguns dos melhores líderes de cada segmento econômico e social brasileiro. Trabalharemos em equipe, sem personalismo, pelo bem do Brasil e vamos adotar um novo estilo de Governo com absoluta transparência e permanente estímulo à participação popular.

O combate à corrupção e a defesa da ética no trato da coisa pública serão objetivos centrais e permanentes do meu Governo. É preciso enfrentar com determinação e derrotar a verdadeira cultura da impunidade que prevalece em certos setores da vida pública.

Não permitiremos que a corrupção, a sonegação e o desperdício continuem privando a população de recursos que são seus e que tanto poderiam ajudar na sua dura luta pela sobrevivência.

Ser honesto é mais do que apenas não roubar e não deixar roubar. É também aplicar com eficiência e transparência, sem desperdícios, os recursos públicos focados em resultados sociais concretos. Estou convencido de que temos, dessa forma, uma chance única de superar os principais entraves ao desenvolvimento sustentado do País. E acreditem, acreditem mesmo, não pretendo desperdiçar essa oportunidade conquistada com a luta de muitos milhões e milhões de brasileiros e brasileiras.

Sob a minha liderança o Poder Executivo manterá uma relação construtiva e fraterna com os outros Poderes da República, respeitando exemplarmente a sua independência e o exercício de suas altas funções constitucionais.

$\mathrm{Eu}$, que tive a honra de ser Parlamentar desta Casa, espero contar com a contribuição do Congresso Nacional no debate criterioso e na viabilização das reformas estruturais que o País demanda de todos nós.

Em meu Governo, o Brasil vai estar no centro de todas as atenções. O Brasil precisa fazer em todos os domínios um mergulho para dentro de si mesmo, de forma a criar forças que lhe permitam ampliar o seu horizonte. Fazer esse mergulho não significa fechar as portas e janelas ao mundo. O Brasil pode e deve ter um projeto de desenvolvimento que seja ao mesmo tempo nacional e universalista; significa, simplesmente, adquirir confiança em nós mesmos, na capacidade de fixar objetivos de curto, médio e longo prazos e de buscar realizá-los. O ponto principal do modelo para o qual queremos caminhar é a ampliação da poupança interna e da nossa capacidade 
própria de investimento, assim como o Brasil necessita valorizar o seu capital humano investindo em conhecimento e tecnologia.

Sobretudo vamos produzir. A riqueza que conta é aquela gerada por nossas próprias mãos, produzida por nossas máquinas, pela nossa inteligência e pelo nosso suor.

O Brasil é grande. Apesar de todas as crueldades e discriminações, especialmente contra as comunidades indígenas e negras, e de todas as desigualdades e dores que não devemos esquecer jamais, o povo brasileiro realizou uma obra de resistência e construção nacional admirável. Construiu, ao longo do século, uma nação plural, diversificada, contraditória até, mas que se entende de uma ponta a outra do Território. Dos encantados da Amazônia aos orixás da Bahia; do frevo pernambucano às escolas de samba do Rio de Janeiro; dos tambores do Maranhão ao barroco mineiro; da arquitetura de Brasília à música sertaneja.

Estendendo o arco de sua multiplicidade nas culturas de São Paulo, do Paraná, de Santa Catarina, do Rio Grande do Sul e da Região Centro-Oeste. Esta é uma nação que fala a mesma língua, partilha os mesmos valores fundamentais, se sente que é brasileira.

Onde a mestiçagem e o sincretismo se impuseram, dando uma contribuição original ao mundo, onde judeus e árabes conversam sem medo, onde toda migração é bem-vinda, porque sabemos que em pouco tempo, pela nossa própria capacidade de assimilação e de bem-querer, cada migrante se transforma em mais um brasileiro.

Esta Nação que se criou sob o céu tropical tem que dizer a que veio; internamente, fazendo justiça à luta pela sobrevivência em que seus filhos se acham engajados; externamente, afirmando a sua presença soberana e criativa no mundo. Nossa política externa refletirá também os anseios de mudança que se expressaram nas ruas. No meu Governo, a ação diplomática do Brasil estará orientada por uma perspectiva humanista e será, antes de tudo, um instrumento do desenvolvimento nacional. Por meio do comércio exterior, da capacitação de tecnologias avançadas, e da busca de investimentos produtivos, o relacionamento externo do Brasil deverá contribuir para a melhoria das condições de vida da mulher e do homem brasileiros, elevando os níveis de renda e gerando empregos dignos.

As negociações comerciais são hoje de importância vital. Em relação à ALCA, nos entendimentos entre o MERCOSUL e a União Européia, que na Organização 
Mundial do Comércio, o Brasil combaterá o protecionismo, lutará pela sua eliminação e tratará de obter regras mais justas e adequadas à nossa condição de País em desenvolvimento. Buscaremos eliminar os escandalosos subsídios agrícolas dos países desenvolvidos que prejudicam os nossos produtores privando-os de suas vantagens comparativas. Com igual empenho, esforçaremo-nos para remover os injustificáveis obstáculos às exportações de produtos industriais. Essencial em todos esses foros é preservar os espaços de flexibilidade para nossas políticas de desenvolvimento nos campos social e regional, de meio ambiente, agrícola, industrial e tecnológico. Não perderemos de vista que o ser humano é o destinatário último do resultado das negociações. De pouco valerá participarmos de esforço tão amplo e em tantas frentes se daí não decorrerem benefícios diretos para o nosso povo. Estaremos atentos também para que essas negociações, que hoje em dia vão muito além de meras reduções tarifárias e englobam um amplo espectro normativo, não criem restrições inaceitáveis ao direito soberano do povo brasileiro de decidir sobre seu modelo de desenvolvimento.

A grande prioridade da política externa durante o meu Governo será a construção de uma América do Sul politicamente estável, próspera e unida, com base em ideais democráticos e de justiça social. Para isso é essencial uma ação decidida de revitalização do MERCOSUL, enfraquecido pelas crises de cada um de seus membros e por visões muitas vezes estreitas e egoístas do significado da integração.

O MERCOSUL, assim como a integração da América do Sul em seu conjunto, é sobretudo um projeto político. Mas esse projeto repousa em alicerce econômico comercial que precisam ser urgentemente reparados e reforçados.

Cuidaremos também das dimensões social, cultural e científico-tecnológica do processo de integração. Estimularemos empreendimentos conjuntos e fomentaremos um vivo intercâmbio intelectual e artístico entre os países sul-americanos. Apoiaremos os arranjos institucionais necessários, para que possa florescer uma verdadeira identidade do MERCOSUL e da América do Sul. Vários dos nossos vizinhos vivem hoje situações difíceis. Contribuiremos, desde que chamados e na medida de nossas possibilidades, para encontrar soluções pacíficas para tais crises, com base no diálogo, nos preceitos democráticos e nas normas constitucionais de cada país.

O mesmo empenho de cooperação concreta e de diálogos substantivos teremos com todos os países da América Latina. 
Procuraremos ter com os Estados Unidos da América uma parceria madura, com base no interesse recíproco e no respeito mútuo. Trataremos de fortalecer o entendimento e a cooperação com a União Européia e os seus Estados-Membros, bem como com outros importantes países desenvolvidos, a exemplo do Japão. Aprofundaremos as relações com grandes nações em desenvolvimento: a China, a Índia, a Rússia, a África do Sul, entre outros.

Reafirmamos os laços profundos que nos unem a todo o continente africano e a nossa disposição de contribuir ativamente para que ele desenvolva as suas enormes potencialidades.

Visamos não só a explorar os benefícios potenciais de um maior intercâmbio econômico e de uma presença maior do Brasil no mercado internacional, mas também a estimular os incipientes elementos de multipolaridade da vida internacional contemporânea.

A democratização das relações internacionais sem hegemonias de qualquer espécie é tão importante para o futuro da humanidade quanto a consolidação e o desenvolvimento da democracia no interior de cada Estado.

Vamos valorizar as organizações multilaterais, em especial as Nações Unidas, a quem cabe a primazia na preservação da paz e da segurança internacionais.

As resoluções do Conselho de Segurança devem ser fielmente cumpridas. Crises internacionais como a do Oriente Médio devem ser resolvidas por meios pacíficos e pela negociação. Defenderemos um Conselho de Segurança reformado, representativo da realidade contemporânea com países desenvolvidos e em desenvolvimento das várias regiões do mundo entre os seus membros permanentes.

Enfrentaremos os desafios da hora atual como o terrorismo e o crime organizado, valendo-nos da cooperação internacional e com base nos princípios do multilateralismo e do Direito Internacional.

Apoiaremos os esforços para tornar a ONU e suas agências instrumentos ágeis e eficazes da promoção do desenvolvimento social e econômico, do combate à pobreza, às desigualdades e a todas as formas de discriminação da defesa dos direitos humanos e da preservação do meio ambiental.

Sim, temos uma mensagem a dar ao mundo: temos de colocar nosso projeto nacional democraticamente em diálogo aberto, como as demais nações do planeta, porque nós somos o novo, somos a novidade de uma civilização que se desenhou sem 
temor, porque se desenhou no corpo, na alma e no coração do povo, muitas vezes, à revelia das elites, das instituições e até mesmo do Estado.

É verdade que a deterioração dos laços sociais no Brasil nas últimas duas décadas decorrentes de políticas econômicas que não favoreceram o crescimento trouxe uma nuvem ameaçadora ao padrão tolerante da cultura nacional. Crimes hediondos, massacres e linchamentos crisparam o País e fizeram do cotidiano, sobretudo nas grandes cidades, uma experiência próxima da guerra de todos contra todos.

Por isso, inicio este mandato com a firme decisão de colocar o Governo Federal em parceria com os Estados a serviço de uma política de segurança pública muito mais vigorosa e eficiente. Uma política que, combinada com ações de saúde, educação, entre outras, seja capaz de prevenir a violência, reprimir a criminalidade e restabelecer a segurança dos cidadãos e cidadãs.

Se conseguirmos voltar a andar em paz em nossas ruas e praças, daremos um extraordinário impulso ao projeto nacional de construir, neste rincão da América, um bastião mundial da tolerância, do pluralismo democrático e do convívio respeitoso com a diferença.

O Brasil pode dar muito a si mesmo e ao mundo. Por isso devemos exigir muito de nós mesmos. Devemos exigir até mais do que pensamos, porque ainda não nos expressamos por inteiro na nossa História, porque ainda não cumprimos a grande missão planetária que nos espera. O Brasil, nesta nova empreitada histórica, social, cultural e econômica, terá de contar, sobretudo, consigo mesmo; terá de pensar com a sua cabeça; andar com as suas próprias pernas; ouvir o que diz o seu coração. E todos vamos ter de aprender a amar com intensidade ainda maior o nosso País, amar a nossa bandeira, amar a nossa luta, amar o nosso povo.

Cada um de nós, brasileiros, sabe que o que fizemos até hoje não foi pouco, mas sabe também que podemos fazer muito mais. Quando olho a minha própria vida de retirante nordestino, de menino que vendia amendoim e laranja no cais de Santos, que se tornou torneiro mecânico e líder sindical, que um dia fundou o Partido dos Trabalhadores e acreditou no que estava fazendo, que agora assume o posto de Supremo Mandatário da Nação, vejo e sei, com toda a clareza e com toda a convicção, que nós podemos muito mais.

E, para isso, basta acreditar em nós mesmos, em nossa força, em nossa capacidade de criar e em nossa disposição para fazer. 
Estamos começando hoje um novo capítulo na História do Brasil, não como nação submissa, abrindo mão de sua soberania, não como nação injusta, assistindo passivamente ao sofrimento dos mais pobres, mas como nação altiva, nobre, afirmandose corajosamente no mundo como nação de todos, sem distinção de classe, etnia, sexo e crença.

Este é um país que pode dar, e vai dar, um verdadeiro salto de qualidade. Este é o País do novo milênio, pela sua potência agrícola, pela sua estrutura urbana e industrial, por sua fantástica biodiversidade, por sua riqueza cultural, por seu amor à natureza, pela sua criatividade, por sua competência intelectual e científica, por seu calor humano, pelo seu amor ao novo e à invenção, mas sobretudo pelos dons e poderes do seu povo.

O que nós estamos vivendo hoje neste momento, meus companheiros e minhas companheiras, meus irmãos e minhas irmãs de todo o Brasil, pode ser resumido em poucas palavras: hoje é o dia do reencontro do Brasil consigo mesmo.

Agradeço a Deus por chegar até aonde cheguei. Sou agora o servidor público número um do meu País.

Peço a Deus sabedoria para governar, discernimento para julgar, serenidade para administrar, coragem para decidir e um coração do tamanho do Brasil para me sentir unido a cada cidadão e cidadã deste País no dia a dia dos próximos quatro anos.

Viva o povo brasileiro! 


\author{
ANEXO B \\ DISCURSO DO EMBAIXADOR CELSO AMORIM POR OCASIÃO DA \\ TRANSMISSÃO DO CARGO DE MINISTRO DE ESTADO DAS RELAÇÕES \\ EXTERIORES, EM BRASÍLIA
}

Brasília, 2 de janeiro de 2003.

Excelentíssimo Senhor Ministro, e caro amigo Professor Celso Lafer

Excelentíssimos Senhores Ministros, Senhores Parlamentares

Senhoras e Senhores Membros do Corpo Diplomático

Senhora Professora Mary Lafer

Senhoras e Senhores,

Desejo agradecer ao Presidente da República Luiz Inácio Lula da Silva a confiança em mim depositada. Vivi hoje, possivelmente, um dos momentos mais emocionantes da minha vida, não só, creio, da minha vida pessoal, mas de minha vida de cidadão. Poucos países que eu tenha visto passaram por um momento de tanta vibração popular com a eleição de um presidente. É, portanto, com o sentimento da grande responsabilidade que decorre dessas expectativas que assumo este cargo.

É também com satisfação que recebo o cargo do Professor Celso Lafer, bom amigo, a quem tive a honra de suceder como Embaixador em Genebra, quando lá estive pela segunda vez, e de quem sempre tenho lições a aprender. Guardarei a de hoje e refletirei sobre ela.

Quero também prestar minha homenagem ao Secretário-Geral que parte, Osmar Chohfi, e na pessoa dele homenageio outros Embaixadores e Chefes da Casa, com quem tive de me relacionar.

Já que estou neste capítulo de evocações e registros, quero também anunciar que estão sendo tomadas as medidas necessárias para a nomeação do Embaixador Samuel Pinheiro Guimarães como Secretário-Geral do Itamaraty. 
Com a eleição do Presidente Lula, o povo brasileiro expressou de forma inequívoca o desejo de ver realizada uma profunda reforma política e social, dentro de um marco pacífico e democrático, com ampla participação popular na condução dos assuntos do Estado. Coerentemente com os anseios manifestados nas urnas, o Brasil terá uma política externa voltada para o desenvolvimento e para a paz, que buscará reduzir o hiato entre nações ricas e pobres, promover o respeito da igualdade entre os povos e a democratização efetiva do sistema internacional. Uma política externa que seja um elemento essencial do esforço de todos para melhorar as condições de vida do nosso povo, e que esteja embasada nos mesmos princípios éticos, humanistas e de justiça social que estarão presentes em todas as ações do Governo Lula.

Convoco todos os diplomatas e servidores do Ministério das Relações Exteriores a participarem ativamente deste grande projeto.

A política externa não é só responsabilidade do Itamaraty, ou mesmo do Governo. Ela envolve a sociedade como um todo. Para definir o interesse nacional em cada situação concreta, reforçarei a coordenação com outros órgãos governamentais e com os diversos setores sociais - trabalhadores, empresários, intelectuais - e entidades da sociedade civil.

Senhoras e Senhores,

O povo brasileiro deu uma grande demonstração de auto-estima ao manifestar sua crença na capacidade de mudar criativamente a realidade. Temos que levar esta postura de ativismo responsável e confiante ao plano das relações externas. Não fugiremos de um protagonismo engajado, sempre que for necessário na defesa do interesse nacional e dos valores que nos inspiram. Como disse o Presidente Lula, precisamos traduzir, de forma persistente, nossos interesses e valores em pontos da agenda internacional.

O cenário em que teremos de realizar essa tarefa é complexo e nem sempre amistoso. A economia mundial está estagnada. Os fluxos financeiros se comportam de forma errática e segundo uma lógica perversa que penaliza os países em desenvolvimento. A despeito das muitas promessas, os mercados dos países desenvolvidos continuam fechados a grande parte dos nossos produtos. Práticas comerciais predatórias dos países ricos nos privam dos benefícios da nossa 
competitividade. No plano político, conflitos que se supunham estarem em vias de solução recrudesceram, alimentados pela intolerância e o fanatismo. Atos terroristas de indescritível barbárie provocam reações e suscitam posturas que têm o potencial de afetar os princípios do multilateralismo. O risco de guerra volta a pairar sobre o mundo. Tudo isso se reflete em crises econômicas, financeiras e políticas, que tendem a ser mais graves nos países mais pobres. Nossa região - a América do Sul - também sofre os efeitos desses abalos.

Senhoras e Senhores,

O aumento das exportações, a busca de tecnologias e investimentos produtivos serão elementos importantes da estratégia nacional de crescimento e da redução da vulnerabilidade externa. Participaremos empenhadamente das diversas negociações comerciais movidos pela busca de vantagens concretas, sem constrangimento de nos apresentarmos como país em desenvolvimento e de reivindicarmos tratamento justo. Saberemos nos articular, sem preconceitos, com as nações que compartilham conosco interesses e preocupações. Atuaremos em cada momento norteados pela necessidade de assegurar a compatibilidade do que está sendo proposto com as políticas nacionais. Lutaremos para preservar o espaço de flexibilidade para que possamos decidir, soberanamente, qual o modelo de desenvolvimento que mais nos convém.

Combateremos práticas protecionistas que tanto prejudicam nossa agricultura e nossa indústria. Trataremos de ampliar os mercados consumidores de bens primários ou semi-elaborados, que continuam a ter um papel importante em nossa pauta. Mas daremos ênfase especial àqueles bens e serviços de maior valor agregado e conteúdo de conhecimento. Para fazermos isso de forma sustentável, teremos que nos empenhar profundamente na verdadeira batalha pela eliminação de barreiras e subsídios que hoje distorcem brutalmente o comércio e privam os países em desenvolvimento de suas vantagens comparativas (as naturais ou aquelas obtidas através do esforço e engenho criativo).

É nesse contexto de busca de oportunidades que vemos as grandes negociações comerciais em curso. Não queremos um Brasil fechado em si mesmo, imune aos ventos do progresso e da competição. Na ALCA, nas negociações MERCOSUL-União Européia e na Organização Mundial do Comércio trataremos de ampliar mercados para 
os produtos e serviços em que somos competitivos, procurando corrigir distorções do passado e evitando restrições excessivas à nossa capacidade de fomentar políticas sociais, ambientais, industriais e tecnológicas.

Ainda que nada esteja acordado em definitivo, os pressupostos em que se baseiam estes processos de negociação vão muito além de meras rebaixas tarifárias. Envolvem aspectos normativos sobre praticamente todos os campos da atividade econômica. Por isso mesmo, devem ser analisados com cuidadosa atenção, sem prejulgamento. A despeito dos prazos desconfortavelmente estreitos de algumas dessas negociações, pretendemos discutir amplamente com empresários, trabalhadores e outros setores sociais e com o Congresso Nacional as posições que devemos tomar, tendo em vista a vasta gama de interesses envolvidos e as complexas articulações que se fazem necessárias, a começar no âmbito do MERCOSUL.

No Governo Lula, a América do Sul será nossa prioridade. O relacionamento com a Argentina é o pilar da construção do MERCOSUL, cuja vitalidade e dinamismo cuidaremos de resgatar. Reforçaremos as dimensões política e social do MERCOSUL, sem perder de vista a necessidade de enfrentar as dificuldades da agenda econômicocomercial, de acordo com um cronograma preciso. Temos que enfrentar com determinação as questões da Tarifa Externa Comum e da União Aduaneira, sem as quais a pretensão de negociar em conjunto com outros países e blocos é mera ilusão. Fundamental para a recuperação do MERCOSUL é a revitalização do Fórum Econômico-Social. Devemos impulsionar igualmente a Comissão Parlamentar Conjunta de modo a reforçar a participação da sociedade no processo de integração. Atribuiremos importância à construção de instituições comuns, de políticas sociais, de parcerias na área educacional e cultural, da livre circulação de pessoas e de mecanismos financeiros e monetários que promovam o comércio e a integração.

Consideramos essencial aprofundar a integração entre os países da América do Sul nos mais diversos planos. A formação de um espaço econômico unificado, com base no livre comércio e em projetos de infraestrutura, terá repercussões positivas tanto internamente quanto no relacionamento da região com o resto do mundo. Vários de nossos vizinhos vivem situações difíceis ou mesmo de crise. O processo de mudança democrática por que o Brasil está passando com o Governo Lula pode ser elemento de inspiração e estabilidade para toda a América do Sul. Respeitaremos zelosamente o princípio da não intervenção, da mesma forma que velaremos para que seja respeitado 
por outros. Mas não nos furtaremos a dar nossa contribuição para a solução de situações conflituosas, desde que convidados e quando considerarmos que poderemos ter um papel útil, tendo em conta o primado da democracia e da constitucionalidade.

Uma América do Sul politicamente estável, socialmente justa e economicamente próspera é um objetivo a ser perseguido não só por natural solidariedade, mas em função do nosso próprio progresso e bem-estar.

Com os Estados Unidos da América partilhamos valores e interesses. Pretendo explorar ao máximo nossa história e amizade, fortalecendo as bases para o entendimento construtivo e a parceria madura. O diálogo fluído com os Estados Unidos da América é de fundamental importância não só em questões econômico-comerciais do nosso interesse imediato, mas também para assegurarmos influencia no encaminhamento dos grandes temas da agenda internacional, de forma compatível com nossas dimensões e valores.

O Brasil manterá uma relação próxima e construtiva com a União Europeia. Reconhecemos a longa história de êxito da União Europeia na construção da paz e da prosperidade pela via da integração. No plano político, o diálogo com a União Europeia e os países que a constituem é importante também com vistas a fortalecer os elementos de multipolaridade do sistema internacional. A cooperação com o Japão e outros países desenvolvidos será também fortalecida.

Forjaremos alianças com grandes países em desenvolvimento. Reforçaremos o diálogo com a China, a Rússia, a Índia, o México e a África do Sul, entre outros. Desenvolveremos, inclusive por meio de parcerias com outros países e organizações, maior cooperação com os países africanos. Angola e Moçambique, que passaram por prolongados conflitos internos, receberão atenção especial. Valorizaremos a cooperação no âmbito da Comunidade dos Países da Língua Portuguesa (CPLP), inclusive com o seu mais novo membro, o Timor Leste.

Nossa política externa não pode estar confinada a uma única região, nem pode ficar restrita a uma única dimensão. O Brasil pode e deve contribuir para a construção de uma ordem mundial pacífica e solidária, fundada no Direito e nos princípios do multilateralismo, consciente do seu peso demográfico, territorial, econômico e cultural, e de ser uma grande democracia em processo de transformação social. O Brasil atuará, sem inibições, nos vários fóruns internacionais, regionais e globais. Incentivaremos a promoção universal dos direitos humanos e o combate a todas as formas de 
discriminação. Lutaremos para viabilizar o desenvolvimento sustentável e para eliminar a pobreza. Apoiaremos a cooperação internacional para o meio ambiente, em especial a implementação do Protocolo de Kyoto e da Convenção de Biodiversidade. Promoveremos o banimento das armas de destruição em massa e daremos impulso aos esforços pelo desarmamento, sobretudo o nuclear. Participaremos da luta contra o terrorismo e o crime organizado, com base na cooperação e no Direito internacional.

A solução pacífica de controvérsias é um dos pilares da diplomacia brasileira. Após um encaminhamento que despertou tantas esperanças, é triste ver a deterioração da situação no Oriente Médio, onde vivem populações com as quais temos vínculos profundos. Não se pode, de forma alguma, abandonar a via pacífica e do diálogo, sob pena de perpetuar-se o sofrimento das populações envolvidas e de desencadear forças incontroláveis com enorme potencial desestabilizador para a região e para o mundo. É preciso resgatar a confiança nas Nações Unidas. O Conselho de Segurança da ONU é o único órgão legalmente habilitado a autorizar o uso da força, este recurso extremo a ser utilizado apenas quando todos os outros esforços e possibilidades se tenham efetivamente esgotado. Mas é igualmente importante para a credibilidade do Conselho em sua tarefa de manter a paz que suas resoluções sejam fielmente cumpridas. Defenderemos a ampliação do Conselho de Segurança com a inclusão de países em desenvolvimento entre seus membros permanentes, de modo a reforçar sua legitimidade e representatividade.

\section{$* * *$}

$\mathrm{O}$ crescente número de brasileiros que vivem e trabalham no exterior torna imprescindível uma vigorosa política consular e cultural capaz de assisti-los e de manter vivos seus vínculos com o País.

As políticas culturais, de cooperação técnica, científica e tecnológica serão elementos essenciais da política externa do Governo Lula.

Senhoras e Senhores,

Considero a honrosa indicação com que o Senhor Presidente da República me distinguiu como sinal de reconhecimento da excelência e patriotismo dos quadros do Serviço Exterior Brasileiro. A imagem pública que se tem da vida diplomática costuma ressaltar apenas os aspectos de maior brilho. Mas há um outro lado, de traumas pessoais 
e familiares, representados pelas constantes mudanças, readaptações forçadas e, em muitos casos, o enfrentamento de situações críticas, do ponto de vista material e psicológico. Tais dificuldades geram necessidades que não podem ser desatendidas.

No caso da carreira diplomática, enfrenta-se um complexo desafio: como conciliar a valiosa experiência acumulada com a justa e necessária renovação nos postos de chefia.

Estou consciente de que as tarefas que temos diante de nós somente podem ser executadas a contento com a participação engajada de todas as categorias de servidores do Itamaraty. Examinarei sempre com atenção e boa vontade suas sugestões e reivindicações.

Senhoras e Senhores, meus colegas,

Não só o Brasil, mas todo o mundo está consciente de que o País vive um grande momento de sua história. Pude testemunhar isso pessoalmente. Não são poucos os analistas, intelectuais ou ativistas políticos de variadas tendências que pensam que do êxito brasileiro depende não só o nosso próprio futuro, mas o de outras nações, que, como nós, buscam a via do desenvolvimento com democracia e justiça social.

Sou tentado a dizer, como o poeta, que tenho duas mãos e o sentimento do mundo. Mas o que me dá confiança é a certeza de que, desta feita, serão muitas mãos a colaborar. A tarefa é grandiosa. O Itamaraty não falhará na sua parte dessa missão.

Muito obrigado. 


\author{
ANEXO C \\ DISCURSO DO EMBAIXADOR SAMUEL PINHEIRO GUIMARÃES POR \\ OCASIÃO DA TRANSMISSÃO DO CARGO DE SECRETÁRIO-GERAL DAS \\ RELAÇÕES EXTERIORES, EM BRASÍLIA
}

Brasília, 9 de janeiro de 2003.

Senhor Ministro de Estado,

Peço agradecer ao Senhor Presidente da República Luiz Inácio Lula da Silva, ter aceito a indicação de meu nome feita por Vossa Excelência, de quem me orgulho de ser amigo e colaborador há mais de quarenta anos.

É um prazer, uma honra e uma tarefa árdua suceder o Embaixador Osmar Chohfi no cargo de Secretário-Geral, que ele tanto abrilhantou.

Agradeço a presença de todos os amigos, colegas e colaboradores.

Agradeço o apoio de meus filhos e de Maria.

A sociedade brasileira tem de enfrentar quatro desafios. Reduzir as disparidades de natureza econômica, de natureza social, de natureza étnica e de gênero. Desafio secular, agora inadiável. A síntese dessas disparidades é a extraordinária concentração de riqueza e de renda; e a fome é a sua expressão mais dramática.

Eliminar as vulnerabilidades externas que constrangem o nosso desenvolvimento econômico, político e social é igualmente tarefa inadiável, inclusive para poder executar políticas públicas que reduzam com eficácia aquelas disparidades.

Essas vulnerabilidades são econômicas, e sua síntese é o elevado déficit em transações correntes; são tecnológicas, e se expressam pela necessidade de importar tecnologia devido à reduzida geração de inovações; são de natureza política, pela ausência do Brasil dos principais centros de decisão mundial, como o Conselho de Segurança da ONU e o G-8; são de natureza militar, diante da imensidão do território e da instabilidade do cenário mundial. 
O terceiro desafio é realizar o potencial brasileiro, cuja dimensão pode ser aferida pelo fato de que o Brasil, juntamente com os Estados Unidos da América e a China, são os três únicos países que aparecem simultaneamente nas relações dos dez países de maior território, de maior população e de maior produto.

O quarto desafio é construção de uma democracia efetiva, que torne cada brasileiro um cidadão que participa da formulação das políticas públicas e do controle das atividades dos representantes e servidores do povo no Congresso, no Executivo e no Judiciário.

O Governo do Presidente Luis Inácio Lula da Silva já enfrenta esses quatro desafios através do programa de combate à fome; da decisão de reconstruir a infraestrutura física e social da economia brasileira, de exercer com plena soberania a defesa dos interesses nacionais e de convocar todos os setores da sociedade para o diálogo mais amplo e mais democrático sobre as políticas públicas.

O Presidente Luiz Inácio Lula da Silva, em seu discurso no Congresso Nacional, e Vossa Excelência, em seu discurso de posse, expressaram com toda a clareza os objetivos da política externa brasileira e a necessidade fundamental de que ela contribua para enfrentar aqueles desafios da sociedade, que são os desafios do Governo e de todos nós.

Tenho certeza de que todos leram, com cuidado, esses discursos e refletiram sobre o que eles significam para o trabalho cotidiano do Itamaraty.

Estou seguro de que, para poder bem cumprir a tarefa de Secretário Geral das Relações Exteriores, e assim honrar a confiança de Vossa Excelência, contarei com a mais dedicada colaboração e o conselho experiente de meus amigos de tantos anos, os Senhores Subsecretários-Gerais, Embaixadores Araújo Castro, Clodoaldo Hugueney, Gilberto Saboia, Carlos Paranhos e, em breve Luiz Felipe de Macedo Soares.

Espero contar igualmente com a cooperação dos Senhores Chefes da Casa e de todos os Embaixadores, diplomatas e funcionários do Itamaraty na realização desta tarefa.

A tarefa da política externa é uma tarefa coordenada de todos os setores da Casa: da área política, da área econômica, da área cultural, da área científica e tecnológica, da área consular, da área administrativa.

Senhoras e Senhores, 
A América do Sul constitui a prioridade da política externa, conforme deixaram claro o Senhor Presidente da República e Vossa Excelência. A ação na América do Sul deverá atender ao objetivo de construção da integração econômica e da cooperação política e social, a partir de uma atitude brasileira que reconheça as assimetrias e procure equacioná-las de forma generosa.

A construção de uma sociedade brasileira mais democrática, mais justa e mais próspera somente poderá ser bem-sucedida se nossos vizinhos também participarem desse processo.

As questões da América do Sul, plenas de desafios e oportunidades para o Governo do Brasil em um mundo multipolar que desejamos construir, terão, assim, toda a prioridade necessária para cumprir o determinado por Vossa Excelência.

Os Estados Unidos da América são a nação mais poderosa econômica, tecnológica e militarmente. Com os Estados Unidos, a sociedade e o Estado brasileiro têm tradicionalmente relações de amizade, de cooperação, de respeito, e de entendimento. Temos a intenção de ampliar esta cooperação, sempre com base nos ideais comuns de democracia, de justiça e de soberania.

A amizade do Brasil pela Europa, pela África, e pela Ásia está em nosso sangue. A contribuição para a formação social brasileira dos descendentes de povos desses continentes é extraordinária e está refletida na pluralidade de nossos sobrenomes e etnias.

A política externa do Presidente Lula, executada por Vossa Excelência, refletirá está realidade. A cooperação com a Europa, econômica e política, tão importante que foi para o nosso desenvolvimento, deve ser expandida. A cooperação com a África deve encontrar novos projetos que contribuam para viabilizar a superação de suas dificuldades, política em que a CPLP terá valioso papel. Com os países do Oriente Próximo, cujos descendentes aqui vivem em harmonia, desejamos contribuir para que encontrem solução pacífica para suas diferenças. Com o Japão, a Índia e a China faremos o melhor para estreitar as nossas relações de toda ordem.

$\mathrm{O}$ desafio da sociedade brasileira exige instrumentos eficazes para garantir a execução de um projeto de desenvolvimento econômico e social sustentável com a mais ampla participação popular. Nas negociações internacionais, será necessário zelar para que a evolução das normas que regem as relações econômicas e políticas entre os 
Estados preservem a capacidade soberana do Estado e da sociedade brasileira de construir o seu futuro.

Seguindo a orientação de Vossa Excelência, e valendo-me do cabedal de conhecimentos de experientes negociadores, darei toda a atenção às negociações econômicas, em especial as da OMC, do MERCOSUL e da ALCA, para contribuir da melhor forma para a defesa e promoção de nossos interesses vitais de longo prazo, lembrando sempre o exemplo de Esaú e Jacó.

A paz e o progresso econômico e social de todos os povos dependem do cumprimento dos princípios da Carta das Nações Unidas: igualdade soberana dos Estados, autodeterminação, não intervenção, solução pacífica de controvérsias. Estes princípios estão inscritos na Constituição brasileira, juntamente para orientar, em caráter permanente e em cada situação, a política externa. E ela deve refletir sempre as palavras do Barão do Rio Branco:

Sou antes brasileiro, e tenho o dever de colocar acima de tudo, de todas as considerações pessoais e de meus sentimentos particulares, a dignidade e a honra do Brasil.

O mundo multipolar sem hegemonias em que todos os Estados obedeçam ao Direito Internacional e procurem resolver suas controvérsias de forma pacífica é o mundo que mais interessa à nação brasileira. Cada dia, cada ato da Chancelaria, deve procurar contribuir para este objetivo. As organizações multilaterais, em especial as Nações Unidas e a OEA, devem contribuir para estes objetivos, e o Brasil nelas atuará de forma ativa.

Vossa Excelência determinou-me que procure a cooperação e a participação de todos os funcionários da Casa no processo de formulação e de execução da política externa. Essa participação depende da formação e do treinamento permanente de todos os funcionários, da organização das carreiras e do aperfeiçoamento dos métodos de trabalho a que dedicarei especial atenção.

Esta participação depende, em suma, de ações concretas para tornar a política externa um projeto de todos, que contribua como instrumento eficaz para o projeto de mudança do Governo do Presidente Lula.

Minhas Senhoras e meus Senhores, 
Como Vossa Excelência lembrou, a auto-estima e a altivez serão sempre a inspiração de nossa política externa. Não nos furtaremos ao protagonismo necessário. Cabe a nós acreditar na possibilidade de transformar o Brasil e o mundo para torná-los mais justos, mais democráticos, mais prósperos, mais humanos.

Muito obrigado. 